SUPPORTING INFORMATION

\title{
Application of Hetero-Triphos Ligands in the Selective Ruthenium-Catalyzed Transformation of Carbon Dioxide to the Formaldehyde Oxidation State
}

Max Seibicke, Max Siebert, Alexander F. Siegle, Sophie M. Gutenthaler, and Oliver Trapp*

Department Chemie, Ludwig-Maximilians-Universität München,

Butenandtstr. 5-13, 81377 München, Germany. 


\section{Contents}

1 Materials and Methods $\quad$ S4

1.1 Preliminary Remarks . . . . . . . . . . . . . . . . . . . . . S4

1.1.1 General Procedures . . . . . . . . . . . . . . . . . . . . S4

1.1.2 Solvents and Reagents . . . . . . . . . . . . . . . . . S4

1.2 Analytical Methods . . . . . . . . . . . . . . . . . . . . S5

1.2.1 NMR Spectroscopy . . . . . . . . . . . . . . . . . . . . S5

1.2.2 Mass Spectrometry . . . . . . . . . . . . . . . . . . . . . . . S5

1.2.3 Vibrational Spectroscopy . . . . . . . . . . . . . . . . S6

1.2.4 Elemental Analysis . . . . . . . . . . . . . . . . . . S6

1.2.5 Crystal Structure Analysis . . . . . . . . . . . . . . . . S6

2 Synthetic Procedures $\quad$ S7

2.1 Synthesis of the Ligands . . . . . . . . . . . . . . . . . . . S7

2.1.1 General procedure for (Diphenylphosphino)methyllithium-TMEDA Complex SI-2 . . . . . . . . . . . . . . . . . . S7

2.1.2 ${ }^{\mathrm{Ph}} \mathrm{Si}$-triphos ${ }^{\mathrm{Ph}} \mathbf{1 a} \ldots \ldots \ldots \ldots \ldots \ldots \ldots$

$2.1 .3{ }^{\mathrm{Me}} \mathrm{Si}_{\text {-triphos }}{ }^{\mathrm{Ph}} \mathbf{1 b} \ldots \ldots \ldots \ldots \ldots \ldots$. . . . . . . . . . . . S10

$2.1 .4 \quad P$-triphos ${ }^{\mathrm{Ph}} \mathbf{1} \ldots \ldots \ldots \ldots \ldots \ldots$. . . . . . . . . . . 12

2.2 Synthesis of the Complexes . . . . . . . . . . . . . . . . . . S14

2.2.1 $\left[\mathrm{Ru}\left({ }^{\mathrm{Ph}} \mathrm{Si}\right.\right.$-triphos $\left.\left.{ }^{\mathrm{Ph}}\right)(\mathrm{tmm})\right] \mathbf{2 a} \ldots \ldots \ldots \ldots \ldots$. . . . . . . . . . 14

2.2.2 $\left[\mathrm{Ru}\left({ }^{\mathrm{Me}} \mathrm{Si}_{\text {-triphos }}{ }^{\mathrm{Ph}}\right)(\mathrm{tmm})\right] 2 \mathrm{~b} \ldots \ldots \ldots \ldots \ldots$. . . . . . . . S16

$2.2 .3\left[\mathrm{Ru}\left(P\right.\right.$-triphos $\left.\left.{ }^{\mathrm{Ph}}\right)(\mathrm{tmm})\right] 2 \mathrm{c} \ldots \ldots \ldots \ldots$. . . . . . . . S 18

$2.2 .4\left[\mathrm{Ru}\left(\operatorname{triphos}^{\mathrm{Ph}}\right)(\mathrm{tmm})\right] \mathrm{SI}-4 \ldots \ldots \ldots \ldots \ldots$. . . . . . . . . . . . . 19

3 Catalytic Investigations $\quad$ S20

3.1 General Procedure for Hydrogenation Reactions . . . . . . . . . . . . . . . S20

3.2 References . . . . . . . . . . . . . . . . . . . . . . S25 
3.3 Catalyst Screening . . . . . . . . . . . . . . . . . . . . . . . . . S27

3.3.1 $\left[\mathrm{Ru}\left({ }^{\mathrm{Ph}}{ }_{\mathrm{Si}}\right.\right.$-triphos $\left.\left.{ }^{\mathrm{Ph}}\right)(\mathrm{tmm})\right] \mathbf{2 a} \ldots \ldots \ldots \ldots$. . . . . . . . . 27

3.3.2 $\left[\mathrm{Ru}\left({ }^{\mathrm{Me}}{ }^{\mathrm{S} i \text {-triphos }}{ }^{\mathrm{Ph}}\right)(\mathrm{tmm})\right] 2 \mathrm{~b} \ldots \ldots \ldots \ldots$. . . . . . . S57

3.3.3 $\left[\mathrm{Ru}\left(P\right.\right.$-triphos $\left.\left.{ }^{\mathrm{Ph}}\right)(\mathrm{tmm})\right] 2 \mathrm{c} \ldots \ldots \ldots \ldots$. . . . . . . . S87

3.3.4 $\left[\mathrm{Ru}\left(\right.\right.$ triphos $\left.\left.^{\mathrm{Ph}}\right)(\mathrm{tmm})\right] \mathrm{SI}-4 \ldots \ldots \ldots \ldots$. . . . . . . . . . S117

3.4 Background Measurements . . . . . . . . . . . . . . . . . . . S119

3.4.1 Run without Catalyst and Co-Catalyst . . . . . . . . . . . . . . . . S119

3.4.2 Run with $\left[\mathrm{Ru}\left({ }^{\mathrm{Ph}} \mathrm{Si}\right.\right.$-triphos $\left.\left.{ }^{\mathrm{Ph}}\right)(\mathrm{tmm})\right]$ 2a and without Co-Catalyst . . . S121

3.4.3 Run with $\left[\mathrm{Ru}\left({ }^{\mathrm{Me}}\right.\right.$ Si-triphos $\left.\left.{ }^{\mathrm{Ph}}\right)(\mathrm{tmm})\right] \mathbf{2 b}$ and without Co-Catalyst . . S123

3.4.4 Run with $\left[\mathrm{Ru}\left(P\right.\right.$-triphos $\left.\left.{ }^{\mathrm{Ph}}\right)(\mathrm{tmm})\right] 2 \mathrm{c}$ and without Co-Catalyst . . . S125

3.4 .5 Run without Catalyst . . . . . . . . . . . . . . . . . . . . . . S127

3.5 Transformation of MF to DMM . . . . . . . . . . . . . . . . . . . . . . S129



3.5.2 $\left[\mathrm{Ru}\left({ }^{\mathrm{Me}} \mathrm{Si}\right.\right.$-triphos $\left.\left.{ }^{\mathrm{Ph}}\right)(\mathrm{tmm})\right] 2 \mathrm{~b} \ldots \ldots \ldots \ldots$. . . . . . . . . S131

3.5.3 $\left[\operatorname{Ru}\left(P\right.\right.$-triphos $\left.\left.^{\mathrm{Ph}}\right)(\mathrm{tmm})\right] 2 \mathrm{c} \ldots \ldots \ldots \ldots$. . . . . . . 133

4 X-Ray Crystallographic Data $\quad \mathbf{S 1 3 5}$

4.1 Data of $\left[\mathrm{Ru}\left({ }^{\mathrm{Ph}} \mathrm{Si}\right.\right.$-triphos $\left.\left.{ }^{\mathrm{Ph}}\right)(\mathrm{tmm})\right] 2 \mathrm{2a} \ldots \ldots \ldots \ldots$. . . . . . . . S135

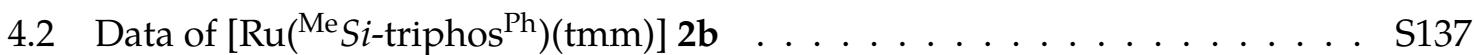

5 Appendix $\quad \mathbf{S 1 3 9}$

5.1 NMR Spectra of the Ligands . . . . . . . . . . . . . . . . . . . . . . . S139

5.1.1 ${ }^{\mathrm{Ph}}{ }_{\mathrm{Si} \text {-triphos }}{ }^{\mathrm{Ph}} 1 \mathrm{1}$. . . . . . . . . . . . . . . . . . . . S139

$5.1 .2{ }^{\mathrm{Me}}{ }_{\mathrm{Si}}$-triphos ${ }^{\mathrm{Ph}} \mathbf{1 b} \ldots \ldots \ldots \ldots \ldots$. . . . . . . . . . . S141

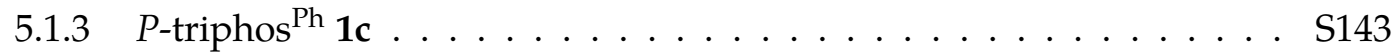

5.2 NMR Spectra of the Complexes . . . . . . . . . . . . . . . . . . . . S145

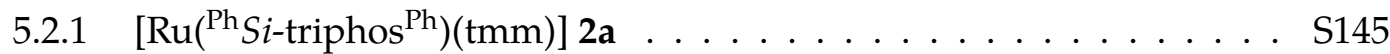

5.2.2 $\left[\mathrm{Ru}\left({ }^{\mathrm{Me}} \mathrm{Si}\right.\right.$-triphos $\left.\left.{ }^{\mathrm{Ph}}\right)(\mathrm{tmm})\right] \mathbf{2 b} \ldots \ldots \ldots \ldots$. . . . . . . . S147

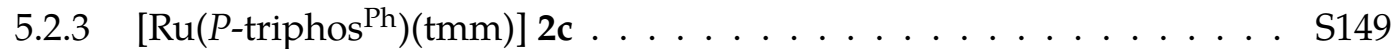

$5.2 .4\left[\mathrm{Ru}\left(\operatorname{triphos}^{\mathrm{Ph}}\right)(\mathrm{tmm})\right] \mathrm{SI}-4 \ldots \ldots \ldots \ldots \ldots$. . . . . . . . . . . . 151

List of Abbreviations $\quad$ S152

$\begin{array}{ll}\text { Bibliography } & \mathbf{S 1 5 4}\end{array}$ 


\section{Materials and Methods}

\subsection{Preliminary Remarks}

\subsubsection{General Procedures}

Air and moisture sensitive syntheses were carried out within an argon atmosphere under exclusion of air and moisture. The argon gas was dried by silica gel and molecular sieve (4 ̊). All glassware was flame-dried prior to use and standard Schlenk techniques were applied. Reactions at NMR scale were performed in J. Young NMR tubes. The given yields refer to isolated and purified products.

\subsubsection{Solvents and Reagents}

Solvents $\left(\mathrm{Et}_{2} \mathrm{O}\right.$, n-pentane and toluene) were dried in a MB SPS-800 system and stored under nitrogen. All other anhydrous solvents used were bought and directly used or stored under exclusion of air and moisture. Degassing was accomplished by at least three FreezePump-Thaw cycles. The anhydrous and degassed solvents were stored under argon over molecular sieve ( $3 \AA$ ). Argon gas (Ar 5.0), hydrogen gas $\left(\mathrm{H}_{2} 5.0\right)$ and carbon dioxide gas $\left(\mathrm{CO}_{2} 4.5\right)$ were purchased from Air Liquide Deutschland GmbH. Argon gas was purified as described above, whereas hydrogen gas and carbon dioxide gas were used without further purification. All other solvents and chemicals were purchased from manufacturing and trading companies (abcr GmbH, Acros Organics b.v.b.a., Sigma-Aldrich Co. LLC., Strem Chemicals Inc. and TCI Europe N.V.) and stored according to the respective instructions. Isolated compounds were stored under argon and, if needed, at 5 or $-20^{\circ} \mathrm{C}$, respectively. 


\subsection{Analytical Methods}

\subsubsection{NMR Spectroscopy}

NMR spectra were recorded on a $400 \mathrm{MHz}$ Bruker Avance III HD spectrometer, a $400 \mathrm{MHz}$ Bruker Avance III HD spectrometer with a CryoProbe Prodigy and a $800 \mathrm{MHz}$ Bruker Avance III HD spectrometer with a CryoProbe. NMR spectra of air and moisture sensitive compounds were measured using J. Young NMR tubes. The solvent residual signals were used for internal calibration. ${ }^{[1]}$ Chemical shifts $\delta$ are reported in ppm and coupling constants $J$ in Hz. The different multiplicities are defined by s (singlet), $\mathrm{d}$ (doublet), $\mathrm{t}$ (triplet), $\mathrm{q}$ (quartet) and $\mathrm{m}$ (multiplet) or by combinations of these. The assignments in ${ }^{13} \mathrm{C}$ NMR and ${ }^{31} \mathrm{P}$ NMR spectra refer to proton decoupled experiments. The assignment of all signals was realized by two-dimensional NMR spectroscopy $\left({ }^{1} \mathrm{H}-{ }^{1} \mathrm{H}-\mathrm{COSY},{ }^{1} \mathrm{H}-{ }^{13} \mathrm{C}-\mathrm{HSQC}-\mathrm{ME}\right.$ and ${ }^{1} \mathrm{H}_{-}{ }^{13} \mathrm{C}-\mathrm{HMBC}$ experiments). Atom numbering for NMR assignments is not based on IUPAC nomenclature.

For the quantification experiments, ${ }^{1} \mathrm{H}$ NMR spectra were obtained with a pulse width of $3.6 \mu \mathrm{s}$ ( $30^{\circ} \mathrm{flip}$ angle), an acquisition time of $4.1 \mathrm{~s}$ and a delay time of $1.0 \mathrm{~s}$ or a pulse width of $5.0 \mu \mathrm{s}$ ( $30^{\circ}$ flip angle), an acquisition time of $5.1 \mathrm{~s}$ and a delay time of $1.0 \mathrm{~s}$.

\subsubsection{Mass Spectrometry}

Mass spectrometric measurements were performed on a Thermo Finnigan LTQ Ultra FT-ICR. The mode (positive / negative) of the experiment, the solvent used to dissolve the sample and the method of injection together with potential solvents are listed. The $m / z$ value of the most abundant or characteristic peak is given in comparison to the calculated $\mathrm{m} / \mathrm{z}$ value. In case of characteristic peaks, the abundance is given in percent. If isotopic patterns are pronounced, the most intensive peak is indicated. Molecular ions are abbreviated as $M$.

[1] Fulmer, G. R.; Miller, A. J. M.; Sherden, N. H.; Gottlieb, H. E.; Nudelman, A.; Stoltz, B. M.; Bercaw, J. E.; Goldberg, K. I. Organometallics 2010, 29, 2176-2179. 


\subsubsection{Vibrational Spectroscopy}

IR spectra were recorded on a Thermo Scientific Nicolet 700 ATR-FT-IR spectrometer using the purified products without further modification. The background transmission was measured before the sample measurement and subtracted. Wave numbers $\tilde{v}$ are given in $\mathrm{cm}^{-1}$.

\subsubsection{Elemental Analysis}

Elemental analyses were performed using a Elementar vario EL or a Elementar vario MICRO cube instrument. Carbon content in elemental analysis for organic phosphorous compounds may be attenuated due to incomplete combustion and the formation of $\left[\mathrm{P}_{2} \mathrm{O}_{5} \cdot x\left(\mathrm{H}_{2} \mathrm{O}\right) \cdot y \mathrm{C}\right]{ }^{[2]}$

\subsubsection{Crystal Structure Analysis}

X-ray crystallographic analyses were performed on a Bruker D8 Venture TXS. The data sets were recorded using Mo $K \alpha(\lambda=0.71073 \AA)$ radiation. Intensities were corrected for Lorentz and polarization effects. The graphical visualization of the crystal structures was performed by means of the program Mercury.

[2] Fildes, J. E. Microchim. Acta 1970, 58, 978-982. 


\section{Synthetic Procedures}

\subsection{Synthesis of the Ligands}

\subsubsection{General procedure for (Diphenylphosphino)methyllithium-TMEDA Complex}

SI-2<smiles>CCCCCCCCCCCCCCCCCCCC</smiles>

SI-1

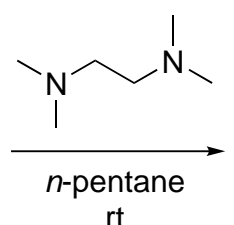

$\mathrm{rt}$<smiles>CN(C)CCN(C)C</smiles>

SI-2

Compound SI-2 is literature known and was synthesized according to a reported procedure. ${ }^{[3]}$ TMEDA (1 eq.) and methyldiphenylphosphine SI-1 (1 eq.) were added to a solution of $n$-BuLi (2.50 $\mathrm{M}$ in $n$-hexane, 1 eq.) in anhydrous degassed $n$-pentane. The reaction mixture was stirred for $19 \mathrm{~h}$ at room temperature during which a yellow solid precipitated. The supernatant solution was removed using a filter cannula and the remaining solid was washed with anhydrous degassed n-pentane to yield SI-2. After work-up, compound SI-2 was directly used in subsequent reactions without analytic characterization.

[3] Schore, N. E.; Benner, L. S.; LaBelle, B. E. Inorg. Chem. 1981, 20, 3200-3208. 


\subsection{2 ${ }^{\mathrm{Ph}}$ Si-triphos ${ }^{\mathrm{Ph}}$ 1a}

Compound SI-2 was synthesized according to the general procedure 1 using TMEDA (3.75 mL, $25.0 \mathrm{mmol})$, methyldiphenylphosphine SI-1 (4.63 mL, 25.0 mmol), n-BuLi (2.50 M in $n$-hexane, $10.0 \mathrm{~mL}, 25.0 \mathrm{mmol}), n$-pentane $(20 \mathrm{~mL})$ as solvent and $n$-pentane $(3 \cdot 15 \mathrm{~mL})$ for washing, with a yield of $4.65 \mathrm{~g}(14.4 \mathrm{mmol}, 58 \%)$.

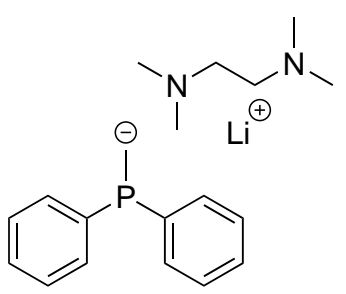

SI-2

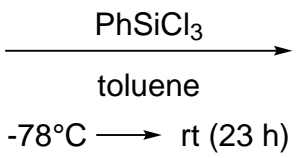

$-78^{\circ} \mathrm{C} \longrightarrow$ rt $(23 \mathrm{~h})$

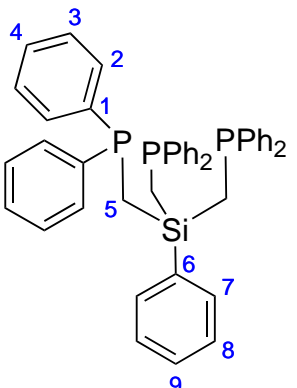

1a

Compound 1a is literature known and was synthesized according to a reported procedure. ${ }^{[4]}$

To a suspension of SI-2 (4.65 g, $14.4 \mathrm{mmol}, 3.5 \mathrm{eq}$.$) in anhydrous degassed toluene (16 mL) at$ $-78^{\circ} \mathrm{C}$, phenyltrichlorosilane $(661 \mu \mathrm{L}, 4.12 \mathrm{mmol}, 1$ eq.) in anhydrous degassed toluene $(4 \mathrm{~mL})$ was added drop by drop. The reaction mixture was allowed to warm to room temperature over the course of $23 \mathrm{~h}$. The volatile components were removed in vacuo and the resulting oily residue was extracted with anhydrous degassed $\mathrm{Et}_{2} \mathrm{O}(3 \cdot 15 \mathrm{~mL})$. The solvent of the extract was removed in vacuo and the oil was first washed with boiling anhydrous degassed $\mathrm{MeOH}(5 \mathrm{~mL})$ and then with anhydrous degassed $n$-pentane $(3 \cdot 3 \mathrm{~mL})$. The product $1 \mathrm{a}$ $(2.06 \mathrm{~g}, 2.93 \mathrm{mmol}, 71 \%)$ was isolated as a beige viscous oil.

${ }^{1} \mathrm{H}$ NMR $\left(\mathrm{CD}_{2} \mathrm{Cl}_{2}, 400 \mathrm{MHz}, 298 \mathrm{~K}\right)$ :

$\delta=1.37-1.41\left(\mathrm{~m}, 6 \mathrm{H}, \mathrm{H}^{5}\right), 7.15-7.22\left(\mathrm{~m}, 3 \mathrm{H}, \mathrm{H}^{8,9}\right), 7.23-7.32\left(\mathrm{~m}, 30 \mathrm{H}, \mathrm{H}^{2,3,4}\right), 7.44-7.50(\mathrm{~m}, 2 \mathrm{H}$, $\left.\mathrm{H}^{7}\right)$.

${ }^{13} \mathrm{C}\left\{{ }^{1} \mathrm{H}\right\}$ NMR $\left(\mathrm{CD}_{2} \mathrm{Cl}_{2}, 101 \mathrm{MHz}, 298 \mathrm{~K}\right)$ :

$\delta=12.5\left(\mathrm{dt},{ }^{1} J_{\mathrm{C}-\mathrm{P}}=32.3 \mathrm{~Hz},{ }^{3} \mathrm{~J}_{\mathrm{C}-\mathrm{P}}=4.7 \mathrm{~Hz}, 3 \mathrm{C}, \mathrm{C}^{5}\right), 127.7\left(\mathrm{~s}, 2 \mathrm{C}, \mathrm{C}^{8}\right), 128.5-128.8(\mathrm{~m}, 12 \mathrm{C}$, $\left.\mathrm{C}^{3}\right), 128.8\left(\mathrm{~s}, 6 \mathrm{C}, \mathrm{C}^{4}\right), 129.6\left(\mathrm{~s}, 1 \mathrm{C}, \mathrm{C}^{9}\right), 132.7-133.2\left(\mathrm{~m}, 12 \mathrm{C}, \mathrm{C}^{2}\right), 135.0-135.2\left(\mathrm{~m}, 2 \mathrm{C}, \mathrm{C}^{7}\right)$, 135.8-136.0 (m, 1C, $\left.\mathrm{C}^{6}\right), 141.1-141.5\left(\mathrm{~m}, 6 \mathrm{C}, \mathrm{C}^{1}\right)$.

[4] Neumeyer, F.; Lipschutz, M. I.; Tilley, T. D. Eur. J. Inorg. Chem. 2013, 2013, 6075-6078. 
${ }^{31} \mathrm{P}\left\{{ }^{1} \mathrm{H}\right\} \mathrm{NMR}\left(\mathrm{CD}_{2} \mathrm{Cl}_{2}, 162 \mathrm{MHz}, 298 \mathrm{~K}\right)$ :

$\delta=-24.39(\mathrm{~s}, 3 \mathrm{P})$.

HR-MS (ESI ${ }^{+}, \mathrm{CHCl}_{3}$, FIA: $\left.\mathrm{ACN} / \mathrm{H}_{2} \mathrm{O}\right)$ :

$[\mathrm{M}+\mathrm{H}]^{+}: \mathrm{C}_{45} \mathrm{H}_{42} \mathrm{P}_{3} \mathrm{Si}^{+} \quad$ calculated $\mathrm{m} / \mathrm{z} \quad 703.2263$

found $\mathrm{m} / \mathrm{z} \quad 703.2256$

IR (FT-ATR):

$\tilde{v}=3744,3688,3628,3137,3067,3048,3027,3012,2997,2980,2906,2697,2673,2609,2581$, $2565,2341,2316,1954,1883,1807,1761,1652,1584,1569,1479,1431,1360,1328,1303,1272$, $1181,1110,1085,1066,1025,998,966,913,879,843,766,733,690$.

\section{EA (vario MICRO):}

$\mathrm{C}_{45} \mathrm{H}_{41} \mathrm{P}_{3} \mathrm{Si}$ calculated [\%] C 76.90; H 5.88

found [\%] C 76.71; H 5.90 


\subsection{3 ${ }^{\mathrm{Me}}$ Si-triphos ${ }^{\mathrm{Ph}} 1 \mathrm{~b}$}

Compound SI-2 was synthesized according to the general procedure 1 using TMEDA (1.50 mL, $10.0 \mathrm{mmol})$, methyldiphenylphosphine SI-1 (1.85 mL, 10.0 mmol), n-BuLi (2.50 M in $n$-hexane, $4.0 \mathrm{~mL}, 10.0 \mathrm{mmol}), n$-pentane $(15 \mathrm{~mL})$ as solvent and $n$-pentane $(3 \cdot 8 \mathrm{~mL})$ for washing, with a yield of $1.74 \mathrm{~g}(5.39 \mathrm{mmol}, 54 \%)$.

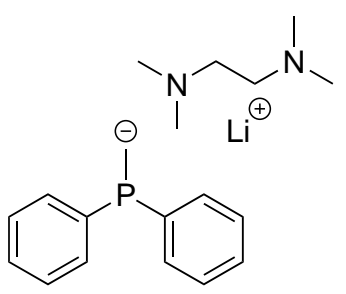

SI-2

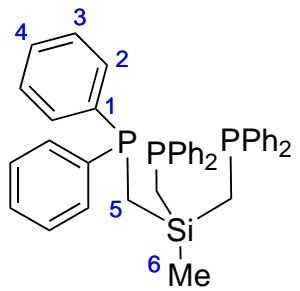

$1 \mathbf{b}$

Compound $\mathbf{1 b}$ is literature known and was synthesized according to a reported procedure. ${ }^{[5]}$

To a suspension of SI-2 (1.74 g, $5.39 \mathrm{mmol}, 3.5$ eq.) in anhydrous degassed toluene (12 mL) at $-78^{\circ} \mathrm{C}$, methyltrichlorosilane $(181 \mu \mathrm{L}, 1.54 \mathrm{mmol}, 1 \mathrm{eq}$.) in anhydrous degassed toluene $(3 \mathrm{~mL})$ was added drop by drop. The reaction mixture was allowed to warm to room temperature over the course of $23 \mathrm{~h}$. The volatile components were removed in vacuo and the resulting oily residue was extracted with anhydrous degassed $\mathrm{Et}_{2} \mathrm{O}(3 \cdot 15 \mathrm{~mL})$. The solvent of the extract was removed in vacuo and the solid was first washed with boiling anhydrous degassed $\mathrm{MeOH}(5 \cdot 4 \mathrm{~mL})$ and then with anhydrous degassed $n$-pentane $(3 \cdot 2 \mathrm{~mL})$. The product $\mathbf{1 b}$ (893 mg, $1.39 \mathrm{mmol}, 90 \%$ ) was isolated as a colorless solid.

${ }^{1} \mathrm{H}$ NMR $\left(\mathrm{CD}_{2} \mathrm{Cl}_{2}, 400 \mathrm{MHz}, 298 \mathrm{~K}\right)$ :

$\delta=(-0.44)-(-0.31)\left(\mathrm{m}, 3 \mathrm{H}, \mathrm{H}^{6}\right), 1.18\left(\mathrm{~s}, 6 \mathrm{H}, \mathrm{H}^{5}\right), 7.25-7.36\left(\mathrm{~m}, 30 \mathrm{H}, \mathrm{H}^{2,3,4}\right)$.

\section{${ }^{13} \mathrm{C}\left\{{ }^{1} \mathrm{H}\right\}$ NMR $\left(\mathrm{CD}_{2} \mathrm{Cl}_{2}, 101 \mathrm{MHz}, 298 \mathrm{~K}\right)$ :}

$\delta=-1.3\left(\mathrm{q}^{,}{ }^{3} J_{\mathrm{C}-\mathrm{P}}=4.7 \mathrm{~Hz}, 1 \mathrm{C}, \mathrm{C}^{6}\right), 13.8\left(\mathrm{dt},{ }^{1} J_{\mathrm{C}-\mathrm{P}}=30.8 \mathrm{~Hz},{ }^{3} J_{\mathrm{C}-\mathrm{P}}=4.8 \mathrm{~Hz}, 3 \mathrm{C}, \mathrm{C}^{5}\right), 128.5-128.7$ $\left(\mathrm{m}, 12 \mathrm{C}, \mathrm{C}^{3}\right), 128.8\left(\mathrm{~s}, 6 \mathrm{C}, \mathrm{C}^{4}\right), 132.7-133.1\left(\mathrm{~m}, 12 \mathrm{C}, \mathrm{C}^{2}\right), 141.4-141.7\left(\mathrm{~m}, 6 \mathrm{C}, \mathrm{C}^{1}\right)$.

\section{${ }^{31} \mathrm{P}\left\{{ }^{1} \mathrm{H}\right\} \mathrm{NMR}\left(\mathrm{CD}_{2} \mathrm{Cl}_{2}, 162 \mathrm{MHz}, 298 \mathrm{~K}\right)$ :}

$\delta=-23.74(\mathrm{~s}, 3 \mathrm{P})$.

[5] Herold, S.; Mezzetti, A.; Venanzi, L. M.; Albinati, A.; Lianza, F.; Gerfin, T.; Gramlich, V. Inorg. Chim. Acta $1995,235,215-231$. 


\section{HR-MS (ESI ${ }^{+}, \mathrm{CHCl}_{3}$, FIA: ACN/H $\left.{ }_{2} \mathrm{O}\right)$ :}

$[\mathrm{M}+\mathrm{H}]^{+}: \mathrm{C}_{40} \mathrm{H}_{40} \mathrm{P}_{3} \mathrm{Si}^{+} \quad$ calculated $m / z \quad 641.2107$ found $m / z \quad 641.2099$

\section{IR (FT-ATR):}

$\tilde{v}=3050,3010,2997,2982,2962,2944,2906,2865,1954,1889,1889,1819,1767,1715,1581$, $1569,1478,1430,1361,1330,1306,1252,1186,1108,1085,1065,1026,1000,986,967,816,804$, $750,735,692$.

EA (vario EL):

$\mathrm{C}_{40} \mathrm{H}_{39} \mathrm{P}_{3} \mathrm{Si} \quad$ calculated [\%] C 74.98; H 6.14

found [\%] C 74.85; H 6.08 


\subsubsection{P-triphos ${ }^{\mathrm{Ph}} 1 \mathrm{c}$}

Compound SI-2 was synthesized according to the general procedure 1 using TMEDA (2.25 mL, $15.0 \mathrm{mmol})$, methyldiphenylphosphine SI-1 (2.79 mL, 15.0 mmol), n-BuLi (2.50 M in $n$-hexane, $6.0 \mathrm{~mL}, 15.0 \mathrm{mmol}), n$-pentane $(10 \mathrm{~mL})$ as solvent and $n$-pentane $(3 \cdot 10 \mathrm{~mL})$ for washing, with a yield of $2.87 \mathrm{~g}(8.90 \mathrm{mmol}, 59 \%)$.

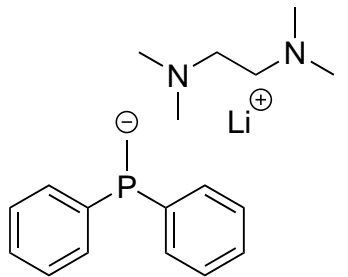

SI-2
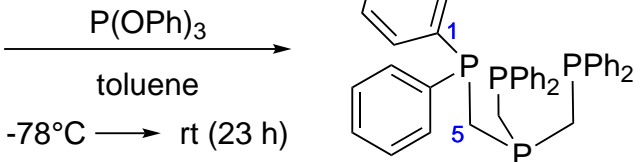

1c

Compound $1 \mathrm{c}$ is literature known and was synthesized according to a reported procedure. ${ }^{[6]}$

To a suspension of SI-2 (2.87 g, $8.90 \mathrm{mmol}, 3.5 \mathrm{eq}$.) in anhydrous degassed toluene (15 mL) at $-78^{\circ} \mathrm{C}$, triphenyl phosphite $(669 \mu \mathrm{L}, 2.54 \mathrm{mmol}, 1$ eq. $)$ in anhydrous degassed toluene $(5 \mathrm{~mL})$ was added drop by drop. The reaction mixture was allowed to warm to room temperature over the course of $23 \mathrm{~h}$. The volatile components were removed in vacuo and the resulting oily residue was dissolved in anhydrous degassed diethylether $(15 \mathrm{~mL})$, filtered over a plug of silica and the solvent was removed in vacuo. The resulting oil was washed with boiling anhydrous degassed $\mathrm{MeOH}(3 \cdot 4 \mathrm{~mL})$ and boiling anhydrous degassed $n$-pentane $(3 \cdot 4 \mathrm{~mL})$. The product 1c (1.05 g, $1.67 \mathrm{mmol}, 66 \%)$ was isolated as a colorless viscous oil.

${ }^{1} \mathrm{H}$ NMR $\left(\mathrm{CD}_{2} \mathrm{Cl}_{2}, 400 \mathrm{MHz}, 298 \mathrm{~K}\right)$ :

$\delta=2.32\left(\mathrm{~d},{ }^{2} \mathrm{~J}_{\mathrm{H}-\mathrm{P}}=2.6 \mathrm{~Hz}, 6 \mathrm{H}, \mathrm{H}^{5}\right), 7.26-7.46\left(\mathrm{~m}, 30 \mathrm{H}, \mathrm{H}^{2,3,4}\right)$.

${ }^{13} \mathrm{C}\left\{{ }^{1} \mathrm{H}\right\}$ NMR $\left(\mathrm{CD}_{2} \mathrm{Cl}_{2}, 101 \mathrm{MHz}, 298 \mathrm{~K}\right)$ :

$\delta=27.8-28.7\left(\mathrm{~m}, 3 \mathrm{C}, \mathrm{C}^{5}\right), 128.6-128.9\left(\mathrm{~m}, 12 \mathrm{C}, \mathrm{C}^{3}\right), 129.1\left(\mathrm{~s}, 6 \mathrm{C}, \mathrm{C}^{4}\right), 133.0-133.4\left(\mathrm{~m}, 12 \mathrm{C}, \mathrm{C}^{2}\right)$, $139.4-139.8\left(\mathrm{~m}, 6 \mathrm{C}, \mathrm{C}^{1}\right)$.

${ }^{31} \mathrm{P}\left\{{ }^{1} \mathrm{H}\right\}$ NMR $\left(\mathrm{CD}_{2} \mathrm{Cl}_{2}, 162 \mathrm{MHz}, 298 \mathrm{~K}\right)$ :

$\delta=-35.40\left(\mathrm{q},{ }^{2} J_{\mathrm{P}-\mathrm{P}}=102.4 \mathrm{~Hz}, 1 \mathrm{P}\right),-24.73\left(\mathrm{~d},{ }^{2} \mathrm{JP}_{\mathrm{P}-\mathrm{P}}=102.4 \mathrm{~Hz}, 3 \mathrm{P}\right)$.

[6] Cámpora, J.; Maya, C. M.; Matas, I.; Claasen, B.; Palma, P.; Álvarez, E. Inorg. Chim. Acta 2006, 359, 3191-3196. 


\section{HR-MS (ESI $\left.{ }^{+}, \mathrm{CHCl}_{3}, \mathrm{FIA}: \mathrm{ACN} / \mathrm{H}_{2} \mathrm{O}\right)$ :}

$[\mathrm{M}+\mathrm{H}]^{+}: \mathrm{C}_{39} \mathrm{H}_{37} \mathrm{P}_{4}{ }^{+} \quad$ calculated $m / z \quad 629.1840$

$$
\text { found } m / z \quad 629.1833
$$

\section{IR (FT-ATR):}

$\tilde{v}=3744,3734,3687,3628,3138,3068,3049,3028,3012,2998,2983,2607,2579,2565,2341$, $1317,1959,1881,1808,1752,1652,1583,1569,1479,1431,1366,1328,1304,1268,1156,1091$, $1067,1025,998,969,910,843,787,735,690$.

\section{EA (vario EL):}

$\mathrm{C}_{39} \mathrm{H}_{36} \mathrm{P}_{4} \quad$ calculated [\%] C 74.52; $\mathrm{H} 5.77$

found [\%] C 73.75; H 5.73 


\subsection{Synthesis of the Complexes}

\subsection{1 $\left[R u\left({ }^{\mathrm{Ph}}\right.\right.$ Si-triphos $\left.\left.{ }^{\mathrm{Ph}}\right)(\mathrm{tmm})\right] 2 \mathrm{a}$}
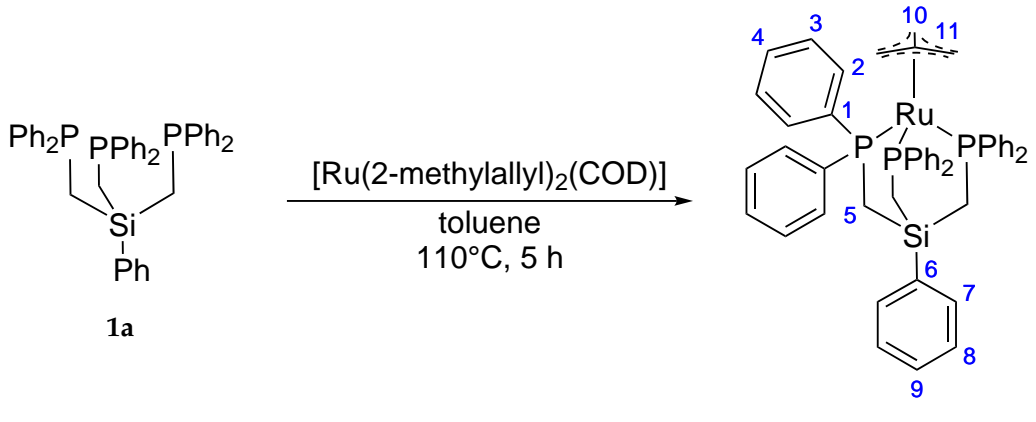

$2 \mathbf{a}$

${ }^{\text {Ph }}$ Si-triphos ${ }^{\mathrm{Ph}}$ 1a (904 mg, $1.29 \mathrm{mmol}, 1.00$ eq.) and [Ru(2-methylallyl) $\left.)_{2}(\mathrm{COD})\right]$ (411 mg, $1.29 \mathrm{mmol}, 1.00 \mathrm{eq}$.) were dissolved in anhydrous degassed toluene $(25 \mathrm{~mL})$. The solution was stirred for $5 \mathrm{~h}$ at $110^{\circ} \mathrm{C}$. The volatile compounds were removed in vacuo by half, inducing precipitation. The supernatant solution was removed using a filter cannula. The solid was washed with a mixture of anhydrous degassed toluene and anhydrous degassed $n$-pentane $(3 \cdot(5+5) \mathrm{mL})$, anhydrous degassed $\mathrm{MeOH}(3 \cdot 5 \mathrm{~mL})$ and anhydrous degassed $n$-pentane (3. $5 \mathrm{~mL})$. The product $2 \mathrm{a}(658 \mathrm{mg}, 767 \mu \mathrm{mol}, 60 \%)$ was isolated as a bright yellow solid.

${ }^{1} \mathrm{H}$ NMR $\left(\mathrm{CDCl}_{3}, 400 \mathrm{MHz}, 298 \mathrm{~K}\right)$ :

$\delta=1.49\left(\mathrm{~s}, 6 \mathrm{H}, \mathrm{H}^{10}\right), 1.89\left(\mathrm{~d},{ }^{2} J_{\mathrm{H}-\mathrm{P}}=7.4 \mathrm{~Hz}, 6 \mathrm{H}, \mathrm{H}^{5}\right), 7.02-7.09\left(\mathrm{~m}, 12 \mathrm{H}, \mathrm{H}^{3}\right), 7.11-7.20(\mathrm{~m}$, $\left.18 \mathrm{H}, \mathrm{H}^{2,4}\right), 7.40-7.45\left(\mathrm{~m}, 3 \mathrm{H}, \mathrm{H}^{8,9}\right)$, 7.52-7.56 (m, 2H, $\left.\mathrm{H}^{7}\right)$.

${ }^{13} \mathrm{C}\left\{{ }^{1} \mathrm{H}\right\}$ NMR $\left(\mathrm{CDCl}_{3}, 101 \mathrm{MHz}, 298 \mathrm{~K}\right)$ :

$\delta=11.0-11.2\left(\mathrm{~m}, 3 \mathrm{C}, \mathrm{C}^{5}\right), 44.6-45.2\left(\mathrm{~m}, 3 \mathrm{C}, \mathrm{C}^{10}\right), 106.1-106.3\left(\mathrm{~m}, 1 \mathrm{C}, \mathrm{C}^{11}\right), 127.6-127.8(\mathrm{~m}, 12 \mathrm{C}$, $\left.\mathrm{C}^{3}\right), 127.9\left(\mathrm{~s}, 6 \mathrm{C}, \mathrm{C}^{4}\right), 128.4\left(\mathrm{~s}, 2 \mathrm{C}, \mathrm{C}^{8}\right), 130.0\left(\mathrm{~s}, 1 \mathrm{C}, \mathrm{C}^{9}\right), 132.0-132.3\left(\mathrm{~m}, 12 \mathrm{C}, \mathrm{C}^{2}\right), 133.9(\mathrm{~s}, 2 \mathrm{C}$, $\left.\mathrm{C}^{7}\right), 137.6-138.0\left(\mathrm{~m}, 1 \mathrm{C}, \mathrm{C}^{6}\right), 142.4-143.0\left(\mathrm{~m}, 6 \mathrm{C}, \mathrm{C}^{1}\right)$.

${ }^{31} \mathrm{P}\left\{{ }^{1} \mathrm{H}\right\}$ NMR $\left(\mathrm{CDCl}_{3}, 162 \mathrm{MHz}, 298 \mathrm{~K}\right)$ :

$\delta=30.95(\mathrm{~s}, 3 \mathrm{P})$.

HR-MS (ESI ${ }^{+}, \mathrm{CHCl}_{3}$, FIA: ACN/H $\left.{ }_{2} \mathrm{O}\right)$ :

$[\mathrm{M}+\mathrm{H}]^{+}: \mathrm{C}_{49} \mathrm{H}_{48} \mathrm{P}_{3} \mathrm{RuSi}^{+} \quad$ calculated $\mathrm{m} / \mathrm{z} \quad 859.1776$ found $\mathrm{m} / \mathrm{z} \quad 859.1770$ 


\section{IR (FT-ATR):}

$\tilde{v}=3071,3049,3018,2990,2942,2894,1585,1571,1480,1431,1373,1306,1272,1185,1111$, $1080,1058,1019,997,891,853,771,761,746,736,693$.

\section{EA (vario MICRO):}

$\mathrm{C}_{49} \mathrm{H}_{47} \mathrm{P}_{3} \mathrm{RuSi} \quad$ calculated [\%] C 68.59; H 5.52

found [\%] C 67.04; H 5.79 


\subsection{2 $\left[\mathrm{Ru}\left({ }^{\mathrm{Me}}\right.\right.$ Si-triphos $\left.\left.{ }^{\mathrm{Ph}}\right)(\mathrm{tmm})\right] 2 \mathrm{~b}$}

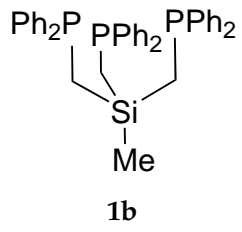

$1 \mathrm{~b}$

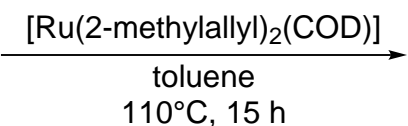

$110^{\circ} \mathrm{C}, 15 \mathrm{~h}$

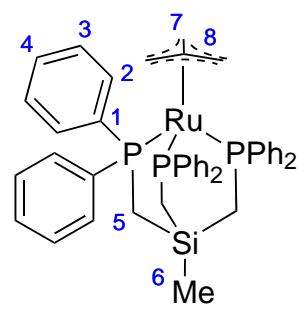

$2 b$

${ }^{\text {Me }}$ Si-triphos ${ }^{\mathrm{Ph}} \mathbf{1 b}$ (560 mg, $874 \mu \mathrm{mol}, 1.00$ eq.) and [Ru(2-methylallyl) $\left.)_{2}(\mathrm{COD})\right](279 \mathrm{mg}$, $874 \mu \mathrm{mol}, 1.00$ eq.) were dissolved in anhydrous degassed toluene $(10 \mathrm{~mL})$. The solution was stirred for $15 \mathrm{~h}$ at $110^{\circ} \mathrm{C}$. The volatile compounds were removed in vacuo by half and anhydrous degassed $n$-pentane $(5 \mathrm{~mL})$ was added, inducing precipitation. The supernatant solution was removed using a filter cannula. The solid was washed with anhydrous degassed toluene $(5 \mathrm{~mL})$ and anhydrous degassed $n$-pentane $(3.5 \mathrm{~mL})$. The product $\mathbf{2 b}(390 \mathrm{mg}$, $490 \mu \mathrm{mol}, 56 \%$ ) was isolated as an off-white solid.

${ }^{1} \mathrm{H}$ NMR $\left(\mathrm{CD}_{2} \mathrm{Cl}_{2}, 800 \mathrm{MHz}, 298 \mathrm{~K}\right)$ :

$\delta=0.34\left(\mathrm{~s}, 3 \mathrm{H}, \mathrm{H}^{6}\right), 1.39\left(\mathrm{~s}, 6 \mathrm{H}, \mathrm{H}^{7}\right), 1.61\left(\mathrm{~d},{ }^{2} \mathrm{~J}_{\mathrm{H}-\mathrm{P}}=7.7 \mathrm{~Hz}, 6 \mathrm{H}, \mathrm{H}^{5}\right), 7.04-7.08\left(\mathrm{~m}, 12 \mathrm{H}, \mathrm{H}^{3}\right)$, 7.08-7.14 (m, 12H, $\left.\mathrm{H}^{2}\right), 7.14-7.18\left(\mathrm{~m}, 6 \mathrm{H}, \mathrm{H}^{4}\right)$.

${ }^{13} \mathrm{C}\left\{{ }^{1} \mathrm{H}\right\}$ NMR $\left(\mathrm{CD}_{2} \mathrm{Cl}_{2}, 201 \mathrm{MHz}, 298 \mathrm{~K}\right)$ :

$\delta=0.5-0.7\left(\mathrm{~m}, 1 \mathrm{C}, \mathrm{C}^{6}\right), 11.9-12.1\left(\mathrm{~m}, 3 \mathrm{C}, \mathrm{C}^{5}\right), 44.5-44.8\left(\mathrm{~m}, 3 \mathrm{C}, \mathrm{C}^{7}\right), 106.4\left(\mathrm{~s}, 1 \mathrm{C}, \mathrm{C}^{8}\right), 127.7-127.9$ $\left(\mathrm{m}, 12 \mathrm{C}, \mathrm{C}^{3}\right), 128.1\left(\mathrm{~s}, 6 \mathrm{C}, \mathrm{C}^{4}\right), 132.2-132.5\left(\mathrm{~m}, 12 \mathrm{C}, \mathrm{C}^{2}\right), 143.0-143.4\left(\mathrm{~m}, 6 \mathrm{C}, \mathrm{C}^{1}\right)$.

${ }^{31} \mathrm{P}\left\{{ }^{1} \mathrm{H}\right\}$ NMR $\left(\mathrm{CD}_{2} \mathrm{Cl}_{2}, 162 \mathrm{MHz}, 298 \mathrm{~K}\right)$ :

$\delta=31.61(\mathrm{~s}, 3 \mathrm{P})$.

HR-MS (ESI ${ }^{+}, \mathrm{CHCl}_{3}$, FIA: $\left.\mathrm{ACN} / \mathrm{H}_{2} \mathrm{O}\right)$ :

$[\mathrm{M}+\mathrm{H}]^{+}: \mathrm{C}_{44} \mathrm{H}_{46} \mathrm{P}_{3} \mathrm{RuSi}^{+} \quad$ calculated $m / z \quad 797.1620$

found $\mathrm{m} / \mathrm{z} \quad 797.1613$

\section{IR (FT-ATR):}

$\tilde{v}=3050,3040,2979,2937,2903,2893,2354,1584,1570,1480,1431,1375,1360,1306,1250$, $1188,1079,1073,1025,995,880,811,767,738,695$. 


\section{EA (vario MICRO):}

$\mathrm{C}_{44} \mathrm{H}_{45} \mathrm{P}_{3} \mathrm{RuSi}$ calculated [\%] C 66.40; H 5.70

found [\%] C 66.48; H 5.79 


\subsection{3 $\left[\mathrm{Ru}\left(P\right.\right.$-triphos $\left.\left.{ }^{\mathrm{Ph}}\right)(\mathrm{tmm})\right] 2 \mathrm{c}$}<smiles>PCP1CPC(P)=CC=CC(Pc2ccccc2)P1</smiles>

$1 c$

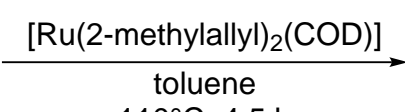

$110^{\circ} \mathrm{C}, 4.5 \mathrm{~h}$

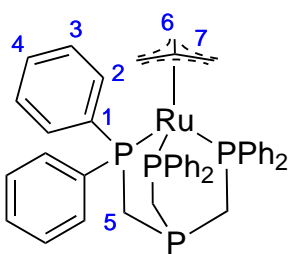

$2 c$

P-triphos ${ }^{\mathrm{Ph}}$ 1c (354 mg, $563 \mu \mathrm{mol}, 1.00$ eq.) and [Ru(2-methylallyl) 2 (COD)] (180 mg, $563 \mu \mathrm{mol}$, 1.00 eq.) were dissolved in anhydrous degassed toluene $(7.5 \mathrm{~mL})$. The solution was stirred for $4.5 \mathrm{~h}$ at $110^{\circ} \mathrm{C}$. After cooling to room temperature, anhydrous degassed $n$-pentane $(5 \mathrm{~mL})$ was added, inducing precipitation. The supernatant solution was removed using a filter cannula. The solid was washed with a mixture of anhydrous degassed toluene and anhydrous degassed $n$-pentane $(2 \cdot(5+5) \mathrm{mL})$ and anhydrous degassed $\mathrm{Et}_{2} \mathrm{O}(3 \cdot 3 \mathrm{~mL})$. The product $2 \mathrm{c}(70.4 \mathrm{mg}, 89.8 \mu \mathrm{mol}, 16 \%)$ was isolated as a beige solid.

${ }^{1} \mathrm{H}$ NMR $\left(\mathrm{CD}_{2} \mathrm{Cl}_{2}, 400 \mathrm{MHz}, 298 \mathrm{~K}\right)$ :

$\delta=1.53\left(\mathrm{~s}, 6 \mathrm{H}, \mathrm{H}^{6}\right), 2.37-2.44\left(\mathrm{~m}, 6 \mathrm{H}, \mathrm{H}^{5}\right), 6.97-7.15\left(\mathrm{~m}, 30 \mathrm{H}, \mathrm{H}^{2,3,4}\right)$.

${ }^{13} \mathrm{C}\left\{{ }^{1} \mathrm{H}\right\}$ NMR $\left(\mathrm{CD}_{2} \mathrm{Cl}_{2}, 201 \mathrm{MHz}, 298 \mathrm{~K}\right)$ :

$\delta=14.5-14.8\left(\mathrm{~m}, 3 \mathrm{C}, \mathrm{C}^{5}\right), 44.9-45.1\left(\mathrm{~m}, 3 \mathrm{C}, \mathrm{C}^{6}\right), 106.7\left(\mathrm{~s}, 1 \mathrm{C}, \mathrm{C}^{7}\right), 127.9-128.1\left(\mathrm{~m}, 12 \mathrm{C}, \mathrm{C}^{3}\right)$, $128.3\left(\mathrm{~s}, 6 \mathrm{C}, \mathrm{C}^{4}\right), 132.2-132.4\left(\mathrm{~m}, 12 \mathrm{C}, \mathrm{C}^{2}\right), 142.4-142.6\left(\mathrm{~m}, 6 \mathrm{C}, \mathrm{C}^{1}\right)$.

${ }^{31} \mathrm{P}\left\{{ }^{1} \mathrm{H}\right\}$ NMR $\left(\mathrm{CD}_{2} \mathrm{Cl}_{2}, 162 \mathrm{MHz}, 298 \mathrm{~K}\right)$ :

$\delta=-22.55\left(\mathrm{q},{ }^{2} J_{\mathrm{P}-\mathrm{P}}=17.4 \mathrm{~Hz}, 1 \mathrm{P}\right), 27.50\left(\mathrm{~d},{ }^{2} J_{\mathrm{P}-\mathrm{P}}=17.4 \mathrm{~Hz}, 3 \mathrm{P}\right)$.

HR-MS (ESI ${ }^{+}, \mathrm{CHCl}_{3}$, FIA: ACN/H $\left.{ }_{2} \mathrm{O}\right)$ :

$[\mathrm{M}+\mathrm{H}]^{+}: \mathrm{C}_{43} \mathrm{H}_{43} \mathrm{P}_{4} \mathrm{Ru}^{+} \quad$ calculated $m / z \quad 785.1353$

found $\mathrm{m} / \mathrm{z} \quad 785.1350$

\section{IR (FT-ATR):}

$\tilde{v}=3072,3050,3016,2988,2890,1585,1571,1480,1432,1371,1308,1261,1186,1155,1133$, $1081,1070,1025,894,852,778,746,735,694$.

\section{EA (vario MICRO):}

$\mathrm{C}_{43} \mathrm{H}_{42} \mathrm{P}_{4} \mathrm{Ru}$ calculated [\%] C 65.90; H 5.40

found [\%] C 64.15; H 5.47 


\subsection{4 [Ru(triphos $\left.\left.{ }^{\mathrm{Ph}}\right)(\mathrm{tmm})\right] \mathrm{Sl}-4$}<smiles>CC12CP(c3ccccc3)CC(P)(C1)P2c1ccccc1</smiles>

SI-3

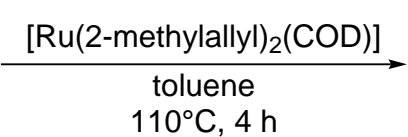
$110^{\circ} \mathrm{C}, 4 \mathrm{~h}$

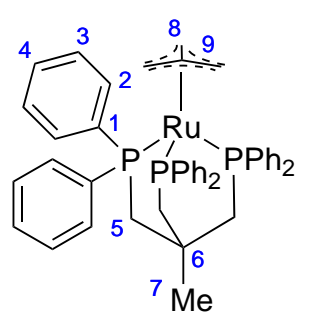

SI-4

Compound SI-4 is literature known and was synthesized according to a reported procedure. ${ }^{[7,8]}$

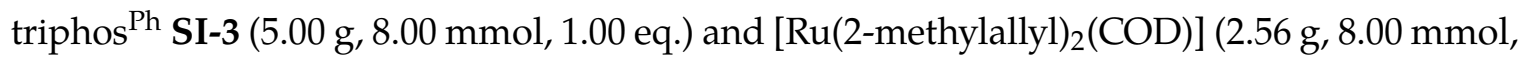
1.00 eq.) were dissolved in anhydrous degassed toluene $(100 \mathrm{~mL})$. The solution was stirred for $4 \mathrm{~h}$ at $110^{\circ} \mathrm{C}$. The volatile compounds were removed in vacuo. The resulting solid was washed with a mixture of anhydrous degassed toluene and anhydrous degassed $n$-pentane $(2 \cdot(20+50) \mathrm{mL})$ and anhydrous degassed $n$-pentane $(50 \mathrm{~mL})$. The product SI-4 $(3.87 \mathrm{~g}$, $4.96 \mathrm{mmol}, 62 \%$ ) was isolated as a beige solid.

${ }^{1} \mathrm{H}$ NMR (CDCl $\left.3,400 \mathrm{MHz}, 298 \mathrm{~K}\right)$ :

$\delta=1.29-1.34\left(\mathrm{~m}, 3 \mathrm{H}, \mathrm{H}^{7}\right), 1.57\left(\mathrm{~s}, 6 \mathrm{H}, \mathrm{H}^{8}\right), 2.10-2.18\left(\mathrm{~m}, 6 \mathrm{H}, \mathrm{H}^{5}\right), 6.82-6.88\left(\mathrm{~m}, 12 \mathrm{H}, \mathrm{H}^{3}\right)$, 6.92-7.03 (m, $\left.18 \mathrm{H}, \mathrm{H}^{2,4}\right)$.

${ }^{31} \mathrm{P}\left\{{ }^{1} \mathrm{H}\right\} \mathrm{NMR}\left(\mathrm{CDCl}_{3}, 162 \mathrm{MHz}, 298 \mathrm{~K}\right)$ :

$\delta=34.80(\mathrm{~s}, 3 \mathrm{P})$.

HR-MS (ESI ${ }^{+}, \mathrm{CHCl}_{3}$, FIA: ACN/H $\left.\mathrm{H}_{2} \mathrm{O}\right)$ :

$[\mathrm{M}+\mathrm{H}]^{+}: \mathrm{C}_{45} \mathrm{H}_{46} \mathrm{P}_{3} \mathrm{Ru}^{+}(45 \%) \quad$ calculated $m / z \quad 781.1850$

found $\mathrm{m} / \mathrm{z} \quad 781.1868$

[7] Wesselbaum, S.; vom Stein, T.; Klankermayer, J.; Leitner, W. Angew. Chem. Int. Ed. 2012, 51, 7499-7502.

[8] vom Stein, T.; Weigand, T.; Merkens, C.; Klankermayer, J.; Leitner, W. Chem CatChem 2013, 5, 439-441. 


\section{Catalytic Investigations}

\subsection{General Procedure for Hydrogenation Reactions}

All catalyses and the corresponding analyses were performed two times following a procedure previously reported by our group. ${ }^{[9]}$

The catalyses were performed in stainless steel high-pressure autoclaves ( $10 \mathrm{~mL}$ total volume) using an NMR tube as inset and a small stirring bar for mixing. The catalyst and the additive were suspended in a Schlenk tube in $\mathrm{MeOH}$ and the mixture was stirred for $1 \mathrm{~h}$. The autoclave was evacuated and flushed with nitrogen three times before $0.5 \mathrm{~mL}$ reaction mixture was transferred into the NMR tube inset. The carbon dioxide gas line was purged with $\mathrm{CO}_{2}$ and the hydrogen gas line was purged with $\mathrm{H}_{2}$ at least seven times. After the autoclave was pressurized with $\mathrm{CO}_{2}$, the $\mathrm{CO}_{2}$ was deposited by cooling the autoclave to $-78^{\circ} \mathrm{C}$ for $5 \mathrm{~min}$. Then, the autoclave was further pressurized with $\mathrm{H}_{2}$. The closed autoclave was allowed to warm to room temperature for $10 \mathrm{~min}$. The reaction mixture was stirred at the mentioned temperature for the defined time. The autoclaves were cooled to $0^{\circ} \mathrm{C}$ for $15 \mathrm{~min}$ before the gas was discharged. The TONs of the catalyses were determined by ${ }^{1} \mathrm{H}$ NMR spectroscopy. A sample of $50 \mu \mathrm{L}$ of the reaction mixture and $35 \mu \mathrm{L}$ mesitylene as internal standard were dissolved in $450 \mu \mathrm{L}$ DCM- $d_{2}$. ${ }^{[9]}$

The catalysis was also performed in the absence of a catalyst, a co-catalyst or both to demonstrate the need of the catalytic system for the formation of DMM and MF. In all cases, no significant TONs for both of these compounds were obtained.

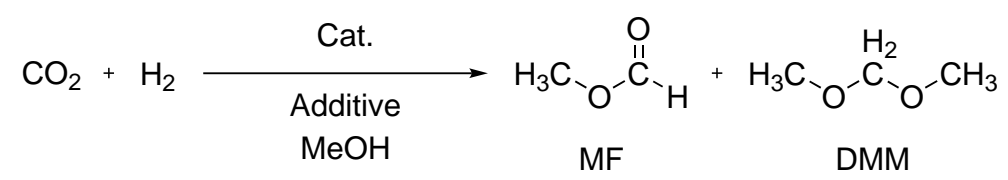

[9] Siebert, M.; Seibicke, M.; Siegle, A. F.; Kräh, S.; Trapp, O. J. Am. Chem. Soc. 2019, 141, 334-341. 

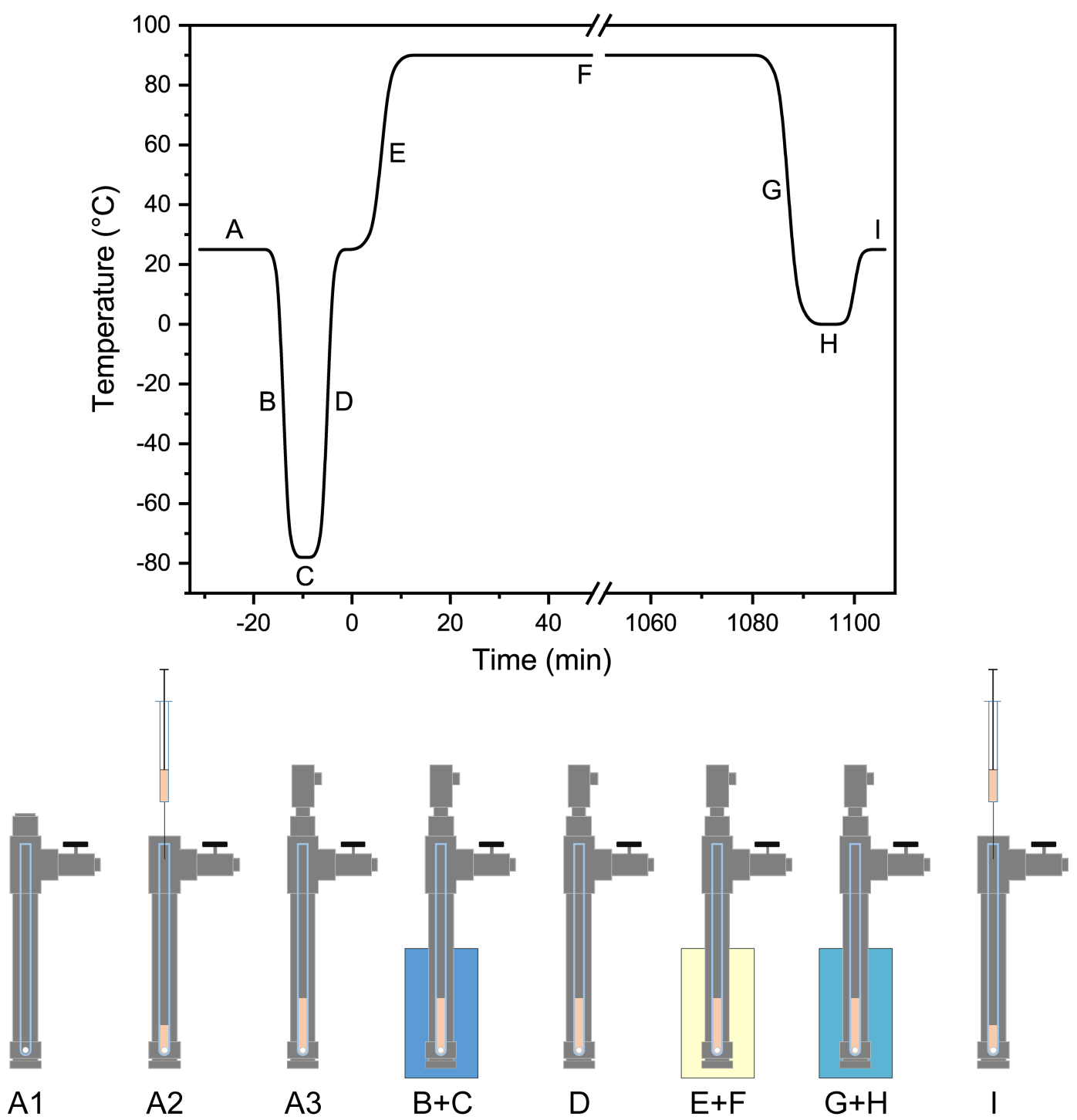

Figure S1: Exemplary timeline of an experimental procedure regarding every step and the respective temperature at which it was performed together with a schematic drawing of the experimental setup.

A1: A glass inset is placed in the autoclave and the autoclave is closed. Evacuation of the autoclave and flushing with nitrogen at $25^{\circ} \mathrm{C}$.

A2: Opening of the autoclave and transfer of the reaction mixture into the glass inset in a nitrogen gas counter-flow at $25^{\circ} \mathrm{C}$. 
A3: Installing of the proportional relief valve in a nitrogen gas counter-flow at $25^{\circ} \mathrm{C}$. Afterwards, the autoclave is pressurized with $\mathrm{CO}_{2}$.

B: Cooling of the autoclave to $-78^{\circ} \mathrm{C}$ using an acetone / dry-ice bath.

$\mathrm{C}$ : The autoclave is kept at $-78^{\circ} \mathrm{C}$ for $5 \mathrm{~min}$ in order to deposit $\mathrm{CO}_{2}$. Afterwards, the autoclave is pressurized with $\mathrm{H}_{2}$.

D: Warming of the autoclave to $25^{\circ} \mathrm{C}$ for $10 \mathrm{~min}$.

E: Heating of the autoclave to the respective temperature $\left(90^{\circ} \mathrm{C}\right.$ in the example) using a preheated oil bath. The temperature of the oil bath is stable within $\pm 0.1^{\circ} \mathrm{C}$ after the autoclave is tempered at the desired temperature.

F: The autoclave is kept at constant temperature over the course of the reaction $(18 \mathrm{~h}$ in the example).

G: Cooling of the autoclave to $0^{\circ} \mathrm{C}$ using an ice bath.

$\mathrm{H}$ : The autoclave is kept at $0{ }^{\circ} \mathrm{C}$ for $15 \mathrm{~min}$.

I: The autoclave is vented carefully and a sample is taken for quantification at $25^{\circ} \mathrm{C}$. 
The TONs for DMM and MF were calculated using equations 3.2 and 3.4 and the peaks at 4.57 - 4.58 and $3.73-3.77$ ppm, respectively.

$$
\begin{aligned}
& \operatorname{TON}_{D M M}=\frac{k \cdot \frac{I_{n t_{D M M}}}{x_{\text {Proton, DMM }}} \cdot \frac{\text { Int }_{\text {mes }}}{x_{\text {Proton, mes }}} \cdot \frac{\rho_{\text {mes }} \cdot V_{\text {mes }}}{M_{\text {mes }}}}{n_{\text {cat }}} \\
& \operatorname{TON}_{D M M}=1258.01 \mu \mathrm{mol} \cdot \frac{\operatorname{Int}_{D M M}}{n_{c a t}} \\
& \operatorname{TON}_{M F}=\frac{k \cdot \frac{I n t_{M F}}{x_{\text {Proton }, M F}} \cdot \frac{I n t_{\text {mes }}}{x_{\text {Proton, mes }}} \cdot \frac{\rho_{\text {mes }} \cdot V_{\text {mes }}}{M_{\text {mes }}}}{n_{\text {cat }}} \\
& \mathrm{TON}_{M F}=838.67 \mu \mathrm{mol} \cdot \frac{\mathrm{Int}_{M F}}{n_{\text {cat }}}
\end{aligned}
$$

where:




The sample standard deviation mentioned for each mean value was calculated using equation 3.5.

$$
S D=\sqrt{\frac{\sum_{i=1}^{N}\left(x_{i}-\bar{x}\right)^{2}}{N-1}}
$$

where:

$$
\begin{aligned}
& S D=\text { Standard Deviation } \\
& i=\text { Number of experiment } \\
& N=\text { Total number of observations in the sample } \\
& x_{i}=\text { Observed values of the sample item } \\
& \bar{x}=\text { Mean value of the observations }
\end{aligned}
$$




\subsection{References}

\section{NMR spectra of DMM ${ }^{[9]}$}

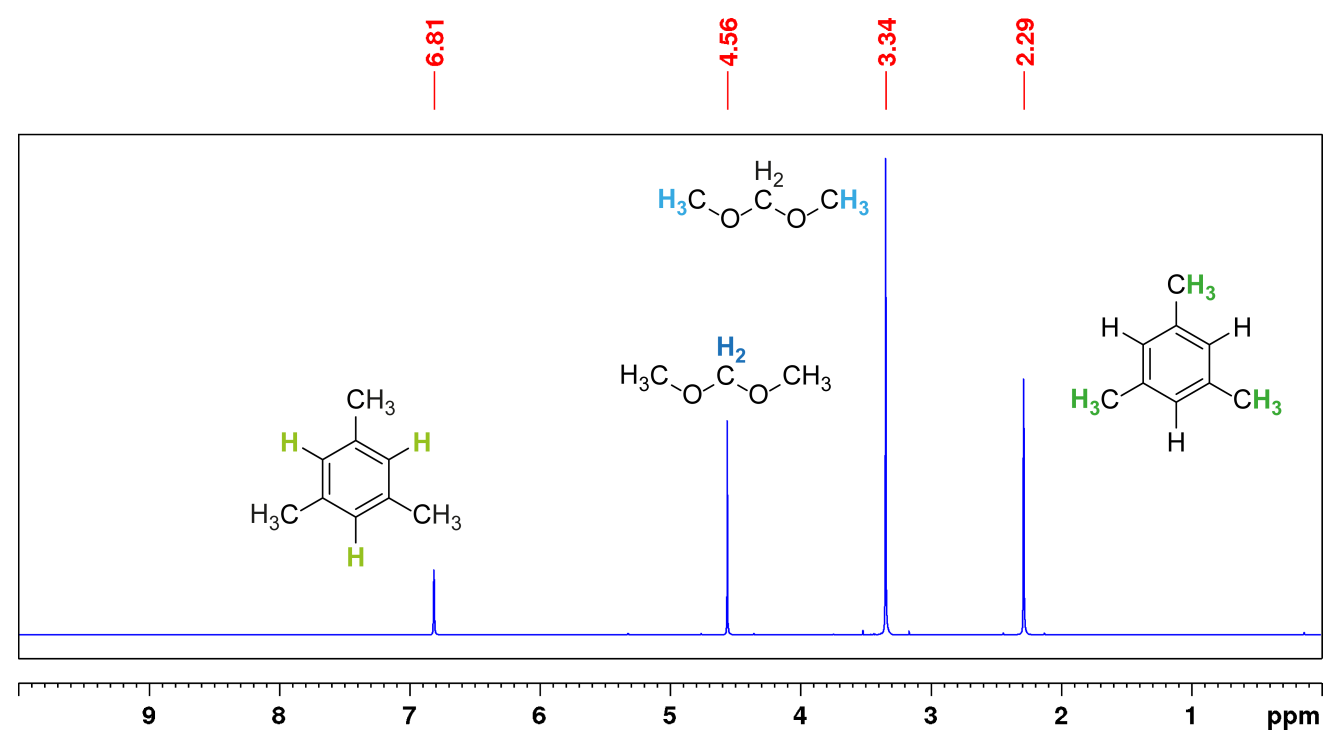

Figure S2: NMR spectra of $50 \mu \mathrm{L}$ DMM and $35 \mu \mathrm{L}$ mesitylene in $450 \mu \mathrm{L}$ DCM- $d_{2}$.

NMR spectra of MF ${ }^{[9]}$

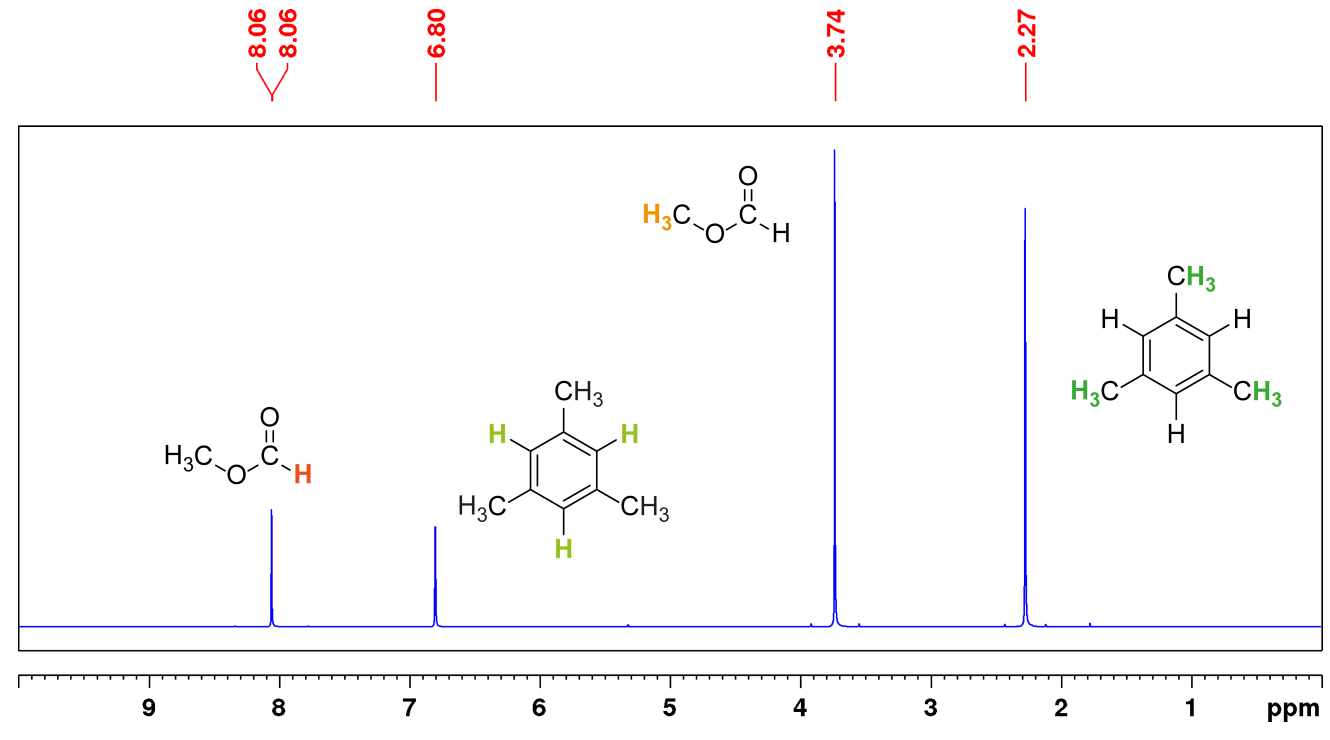

Figure S3: NMR spectra of $50 \mu \mathrm{L}$ MF and $35 \mu \mathrm{L}$ mesitylene in $450 \mu \mathrm{L}$ DCM- $d_{2}$ 


\section{NMR spectra of Mesitylene ${ }^{[9]}$}

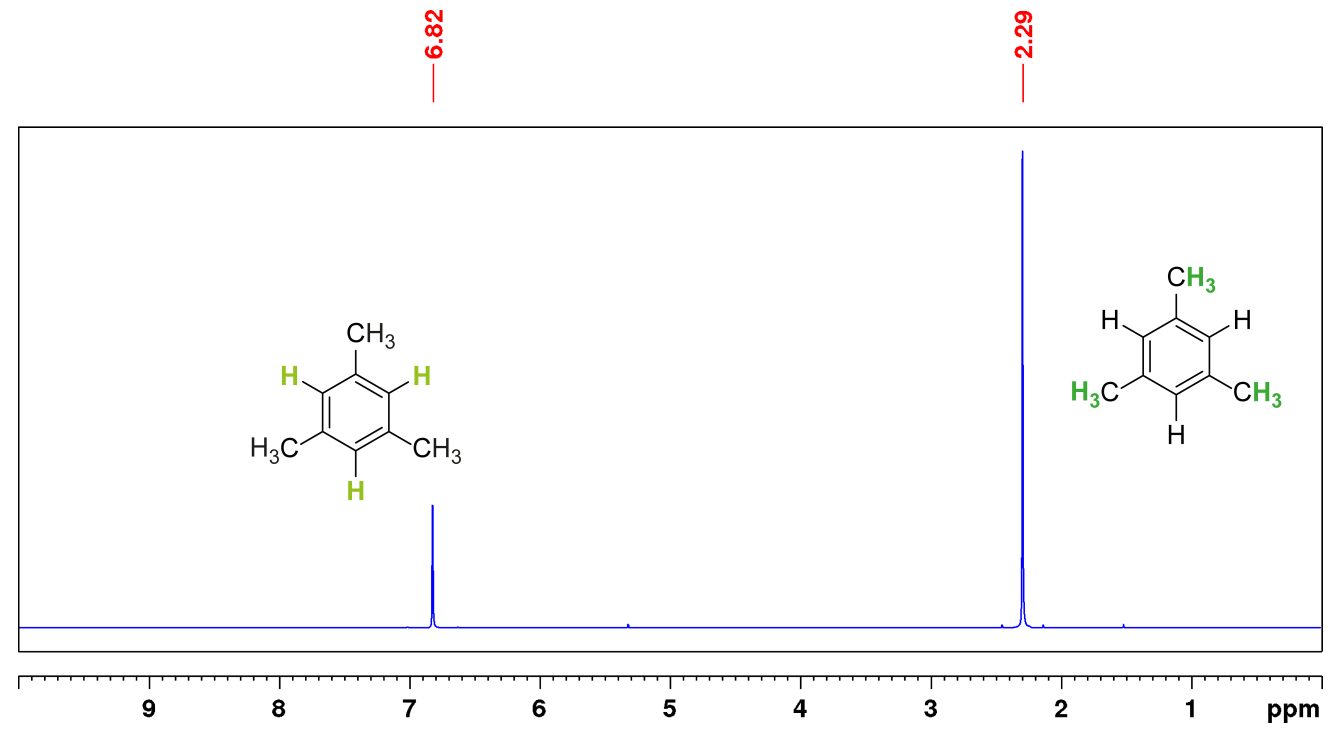

Figure S4: NMR spectra of $35 \mu \mathrm{L}$ mesitylene in $450 \mu \mathrm{L} \mathrm{DCM}-d_{2}$. 


\subsection{Catalyst Screening}

\subsection{1 $\left[R u\left({ }^{\mathrm{Ph}}\right.\right.$ Si-triphos $\left.\left.{ }^{\mathrm{Ph}}\right)(\mathrm{tmm})\right] 2 \mathrm{a}$}

Temperature: $80^{\circ} \mathrm{C}$

$$
\begin{aligned}
T & =80^{\circ} \mathrm{C} & n_{\text {cat }} & =0.375 \mu \mathrm{mol} \\
p_{\mathrm{H} 2} & =90 \mathrm{bar} & n_{\text {add }} & =1.5625 \mu \mathrm{mol} \\
p_{\mathrm{CO} 2} & =20 \mathrm{bar} & \text { add } & =\mathrm{Al}(\mathrm{OTf})_{3} \\
t & =18 \mathrm{~h} & V_{\mathrm{MeOH}} & =0.5 \mathrm{~mL}
\end{aligned}
$$

Table S1: Catalyses results of catalyst $\left[\mathrm{Ru}\left({ }^{\mathrm{Ph}} \mathrm{Si}\right.\right.$-triphos $\left.\left.{ }^{\mathrm{Ph}}\right)(\mathrm{tmm})\right] 2 \mathrm{2a}$ at $80^{\circ} \mathrm{C}$.

\begin{tabular}{lccccc}
\hline & Integral $_{\mathrm{DMM}}$ & TON $_{\mathrm{DMM}}$ & Integral $_{\mathrm{MF}}$ & TON $_{\mathrm{MF}}$ & Ratio \\
\hline Experiment 1 & 0.1321 & 443 & 0.2204 & 493 & 0.90 \\
Experiment 2 & 0.1070 & 359 & 0.2058 & 460 & 0.78 \\
Average & - & $401(60)$ & - & $477(23)$ & $0.84(0.08)$ \\
\hline
\end{tabular}

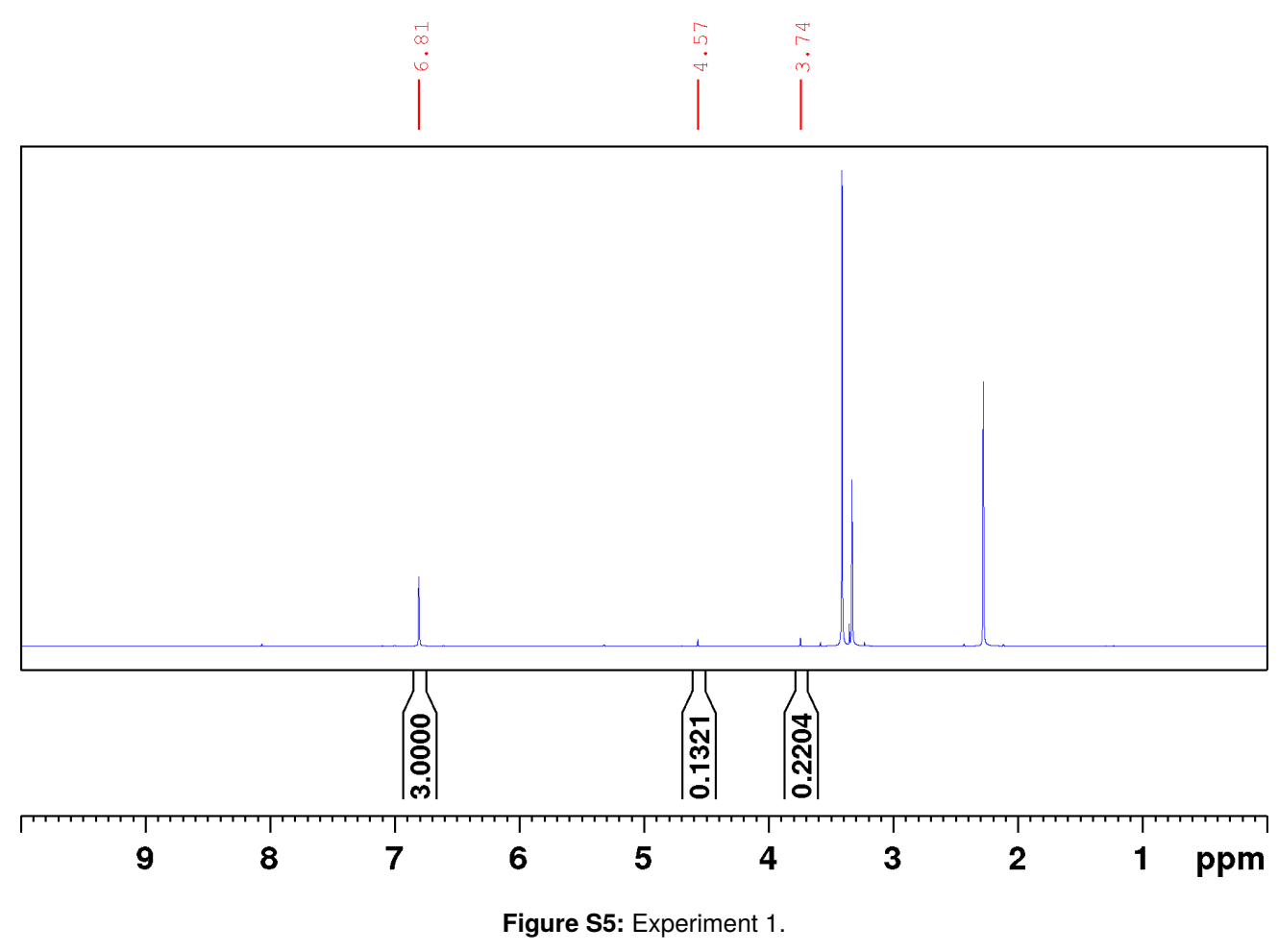




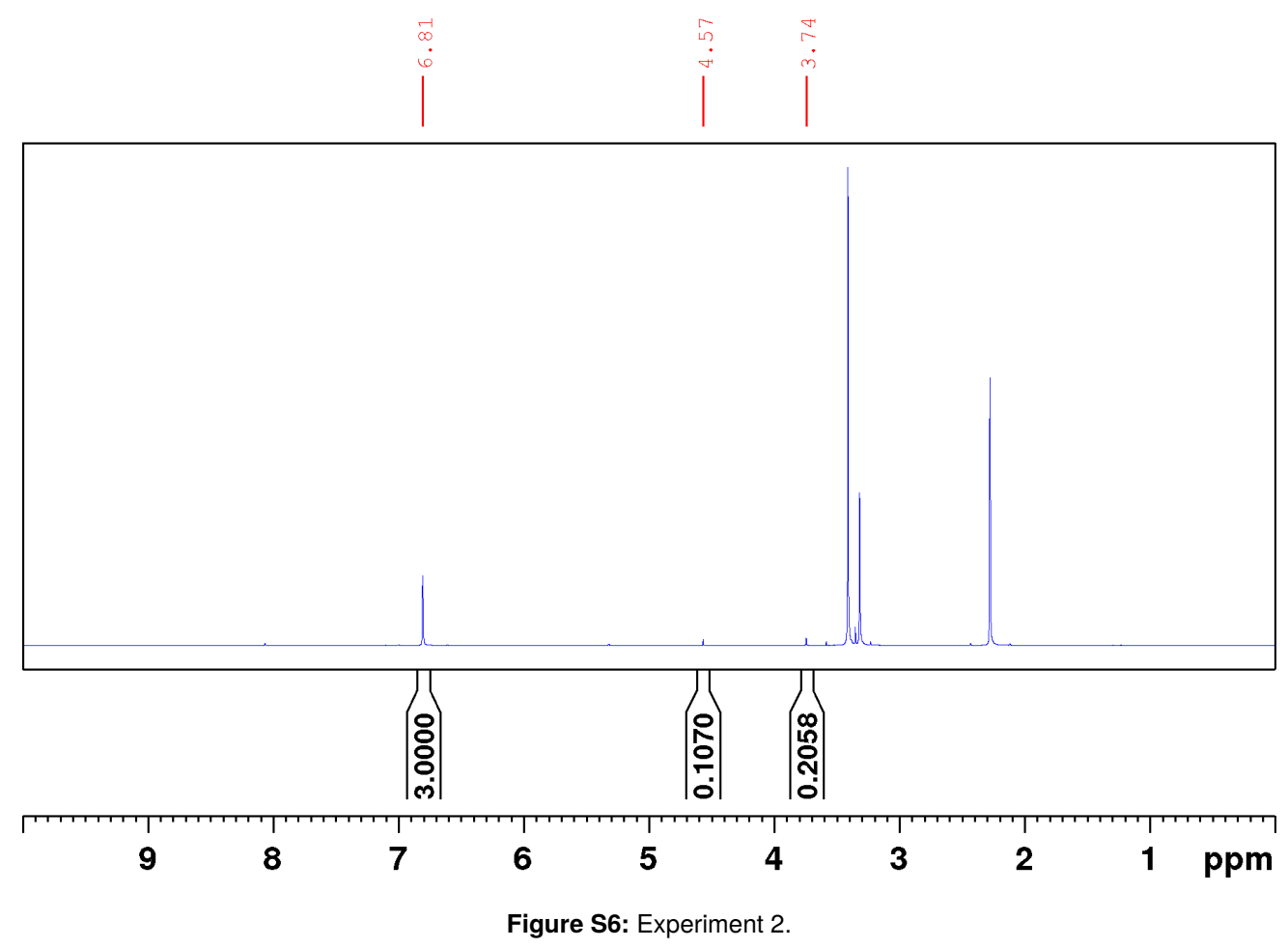




\section{Temperature: $90^{\circ} \mathrm{C}$}

$$
\begin{aligned}
\mathrm{T} & =90^{\circ} \mathrm{C} & n_{\mathrm{cat}} & =0.375 \mu \mathrm{mol} \\
p_{\mathrm{H} 2} & =90 \mathrm{bar} & n_{\mathrm{add}} & =1.5625 \mu \mathrm{mol} \\
p_{\mathrm{CO} 2} & =20 \mathrm{bar} & \text { add } & =\mathrm{Al}(\mathrm{OTf})_{3} \\
t & =18 \mathrm{~h} & V_{\mathrm{MeOH}} & =0.5 \mathrm{~mL}
\end{aligned}
$$

Table S2: Catalyses results of catalyst $\left[\mathrm{Ru}\left({ }^{\mathrm{Ph}} \mathrm{Si}\right.\right.$-triphos $\left.\left.{ }^{\mathrm{Ph}}\right)(\mathrm{tmm})\right] 2 \mathrm{2a}$ at $90^{\circ} \mathrm{C}$.

\begin{tabular}{lccccc}
\hline & Integral $_{\mathrm{DMM}}$ & $\mathrm{TON}_{\mathrm{DMM}}$ & Integral $_{\mathrm{MF}}$ & $\mathrm{TON}_{\mathrm{MF}}$ & Ratio \\
\hline Experiment 1 & 0.1300 & 436 & 0.2540 & 568 & 0.77 \\
Experiment 2 & 0.1305 & 438 & 0.2524 & 564 & 0.78 \\
Average & - & $437(1)$ & - & $566(3)$ & $0.77(0.01)$ \\
\hline
\end{tabular}

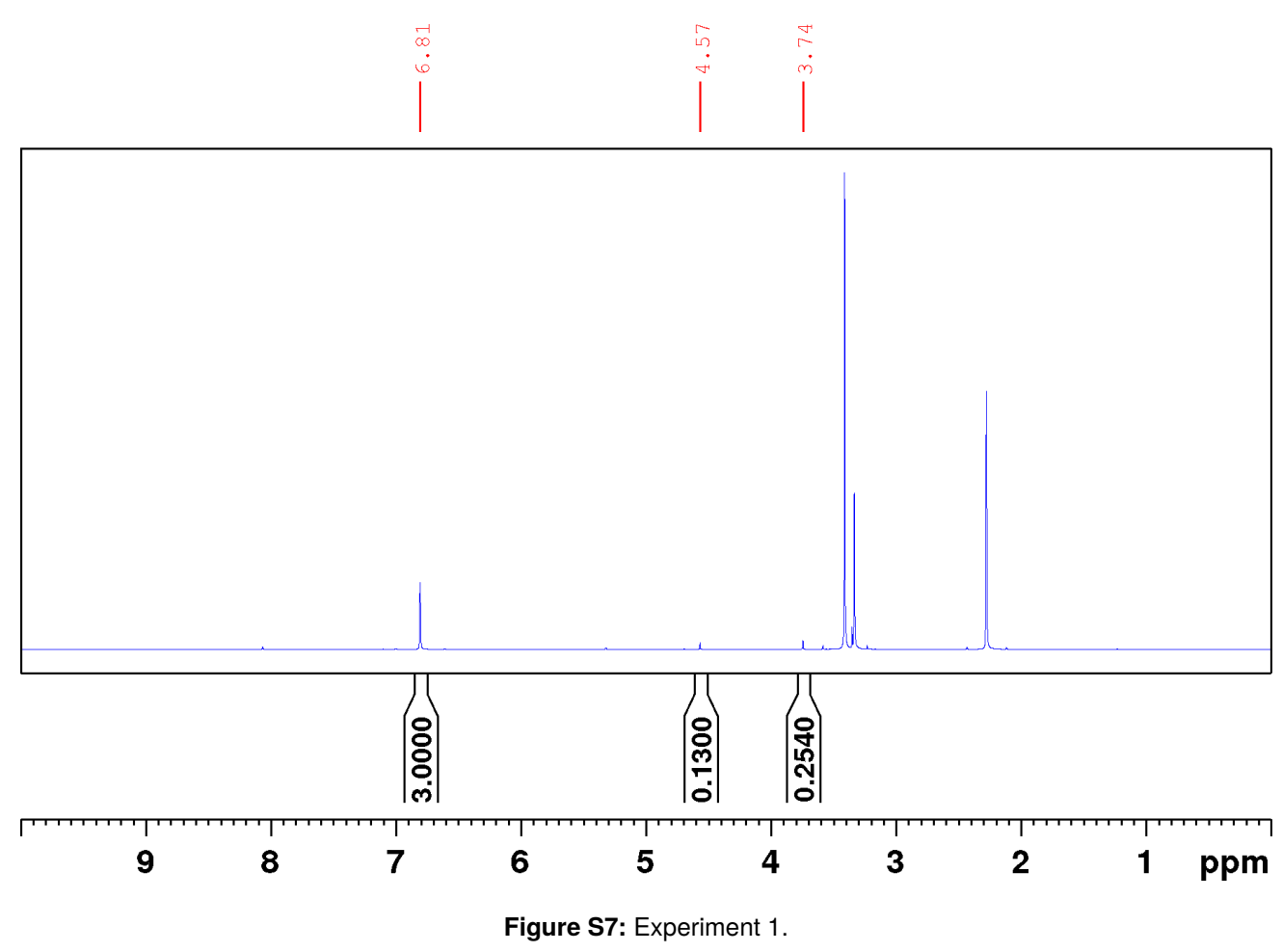







Temperature: $100^{\circ} \mathrm{C}$

$$
\begin{array}{rlrl}
T & =100{ }^{\circ} \mathrm{C} & n_{\text {cat }} & =0.375 \mu \mathrm{mol} \\
p_{\mathrm{H} 2} & =90 \mathrm{bar} & n_{\mathrm{add}} & =1.5625 \mu \mathrm{mol} \\
p_{\mathrm{CO} 2} & =20 \mathrm{bar} & \mathrm{add} & =\mathrm{Al}(\mathrm{OTf})_{3} \\
t & =18 \mathrm{~h} & V_{\mathrm{MeOH}} & =0.5 \mathrm{~mL}
\end{array}
$$

Table S3: Catalyses results of catalyst $\left[\mathrm{Ru}\left({ }^{\mathrm{Ph}} \mathrm{Si}\right.\right.$-triphos $\left.\left.{ }^{\mathrm{Ph}}\right)(\mathrm{tmm})\right] \mathbf{2 a}$ at $100^{\circ} \mathrm{C}$.

\begin{tabular}{lccccc}
\hline & Integral $_{\mathrm{DMM}}$ & $\mathrm{TON}_{\mathrm{DMM}}$ & Integral $_{\mathrm{MF}}$ & $\mathrm{TON}_{\mathrm{MF}}$ & Ratio \\
\hline Experiment 1 & 0.0997 & 334 & 0.3210 & 718 & 0.47 \\
Experiment 2 & 0.0898 & 301 & 0.2664 & 596 & 0.51 \\
Average & - & $318(23)$ & - & $657(86)$ & $0.49(0.03)$ \\
\hline
\end{tabular}

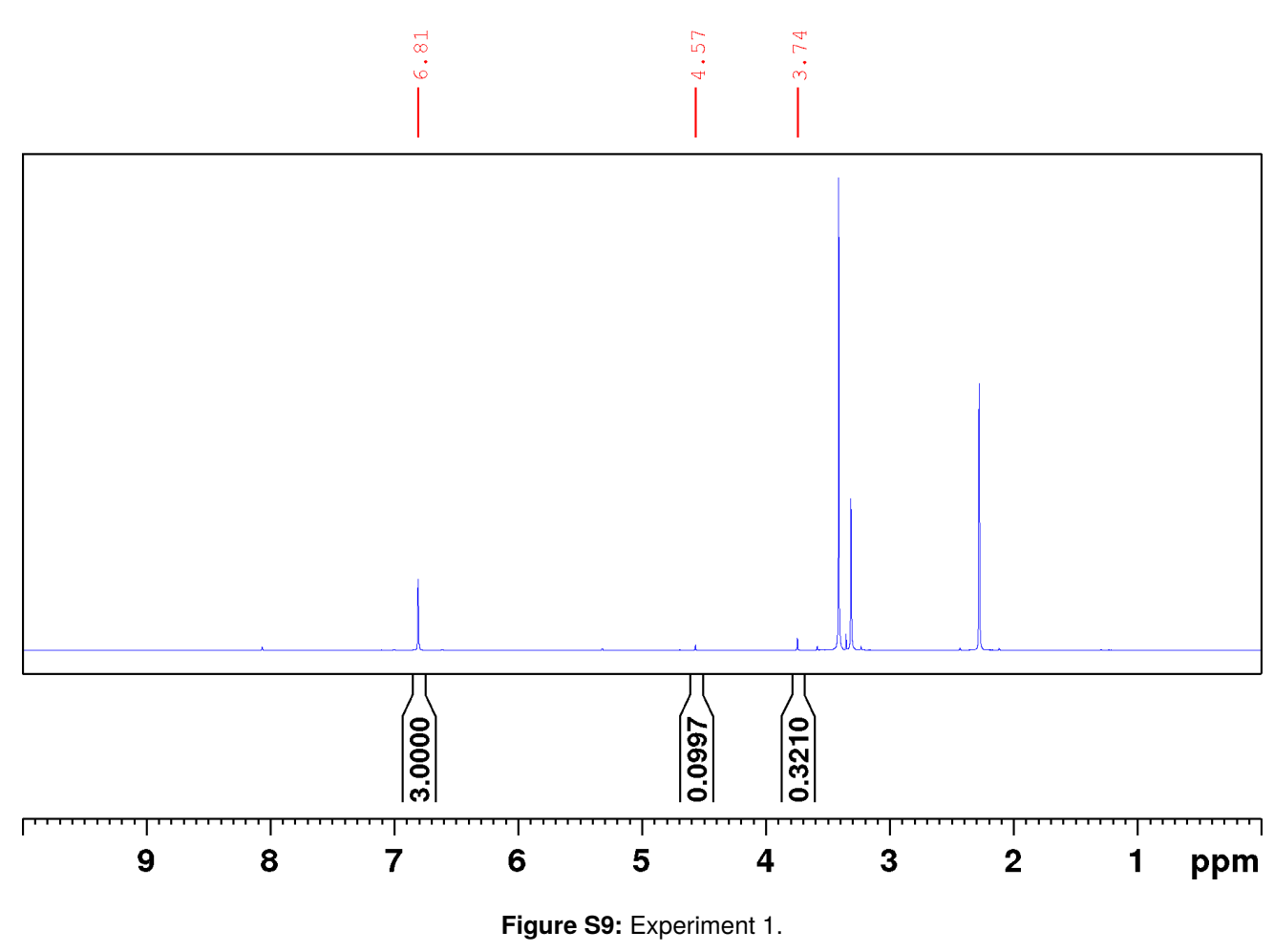




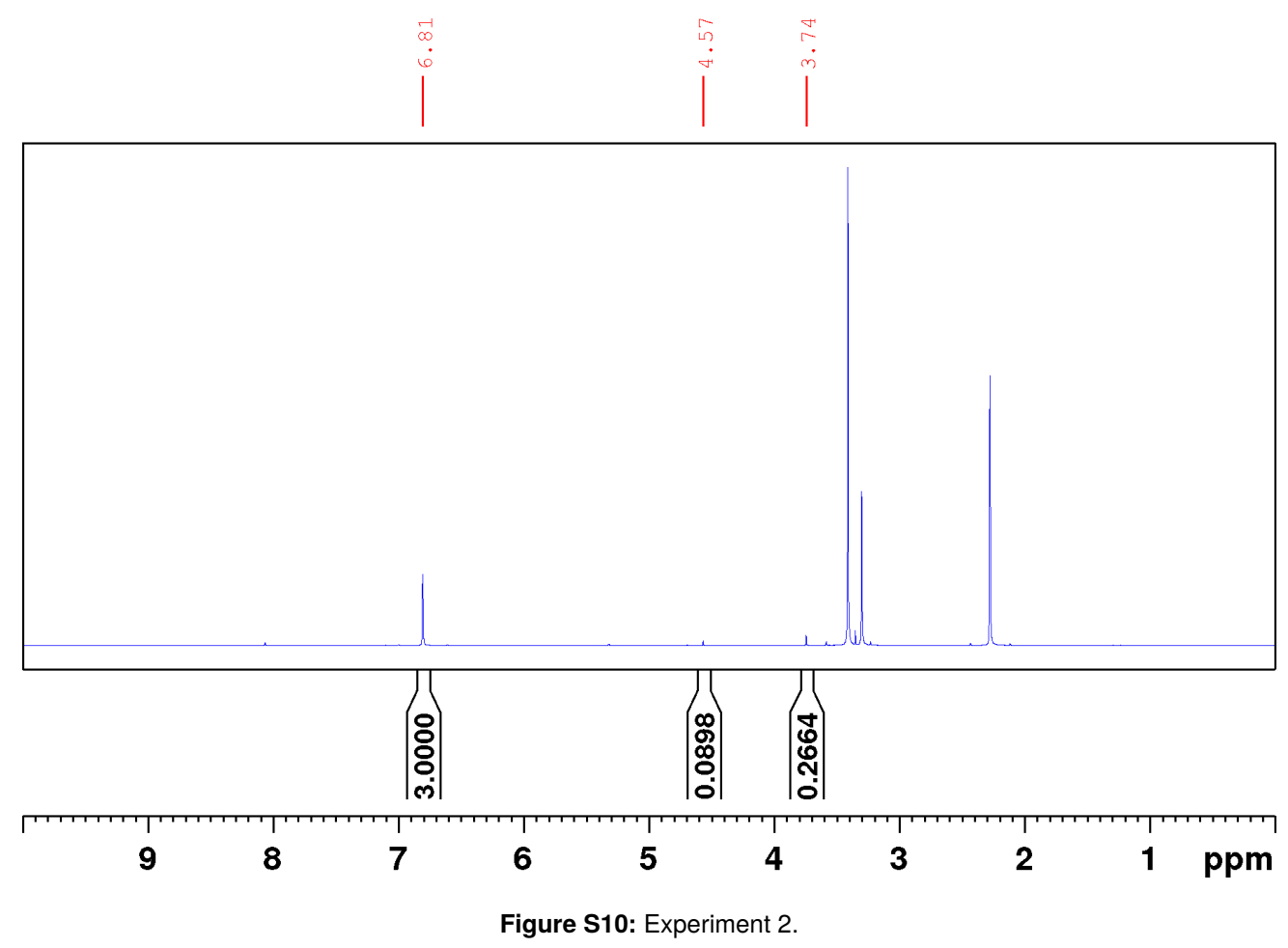




\section{$\mathrm{H}_{2}$ Pressure: 80 bar}

$$
\begin{aligned}
T & =90^{\circ} \mathrm{C} & n_{\text {cat }} & =0.375 \mu \mathrm{mol} \\
p_{\mathrm{H} 2} & =80 \mathrm{bar} & n_{\text {add }} & =1.5625 \mu \mathrm{mol} \\
p_{\mathrm{CO} 2} & =20 \mathrm{bar} & \text { add } & =\mathrm{Al}(\mathrm{OTf})_{3} \\
t & =18 \mathrm{~h} & V_{\mathrm{MeOH}} & =0.5 \mathrm{~mL}
\end{aligned}
$$

Table S4: Catalyses results of catalyst $\left[\mathrm{Ru}\left({ }^{\mathrm{Ph}}{ }^{\mathrm{Si}}\right.\right.$-triphos $\left.\left.{ }^{\mathrm{Ph}}\right)(\mathrm{tmm})\right]$ 2a at 80 bar $_{2}$ pressure.

\begin{tabular}{lccccc}
\hline & Integral $_{\mathrm{DMM}}$ & TON $_{\mathrm{DMM}}$ & Integral $_{\mathrm{MF}}$ & TON $_{\mathrm{MF}}$ & Ratio \\
\hline Experiment 1 & 0.1415 & 475 & 0.2339 & 523 & 0.91 \\
Experiment 2 & 0.1389 & 466 & 0.2533 & 566 & 0.82 \\
Average & - & $471(6)$ & - & $545(30)$ & $0.86(0.06)$ \\
\hline
\end{tabular}

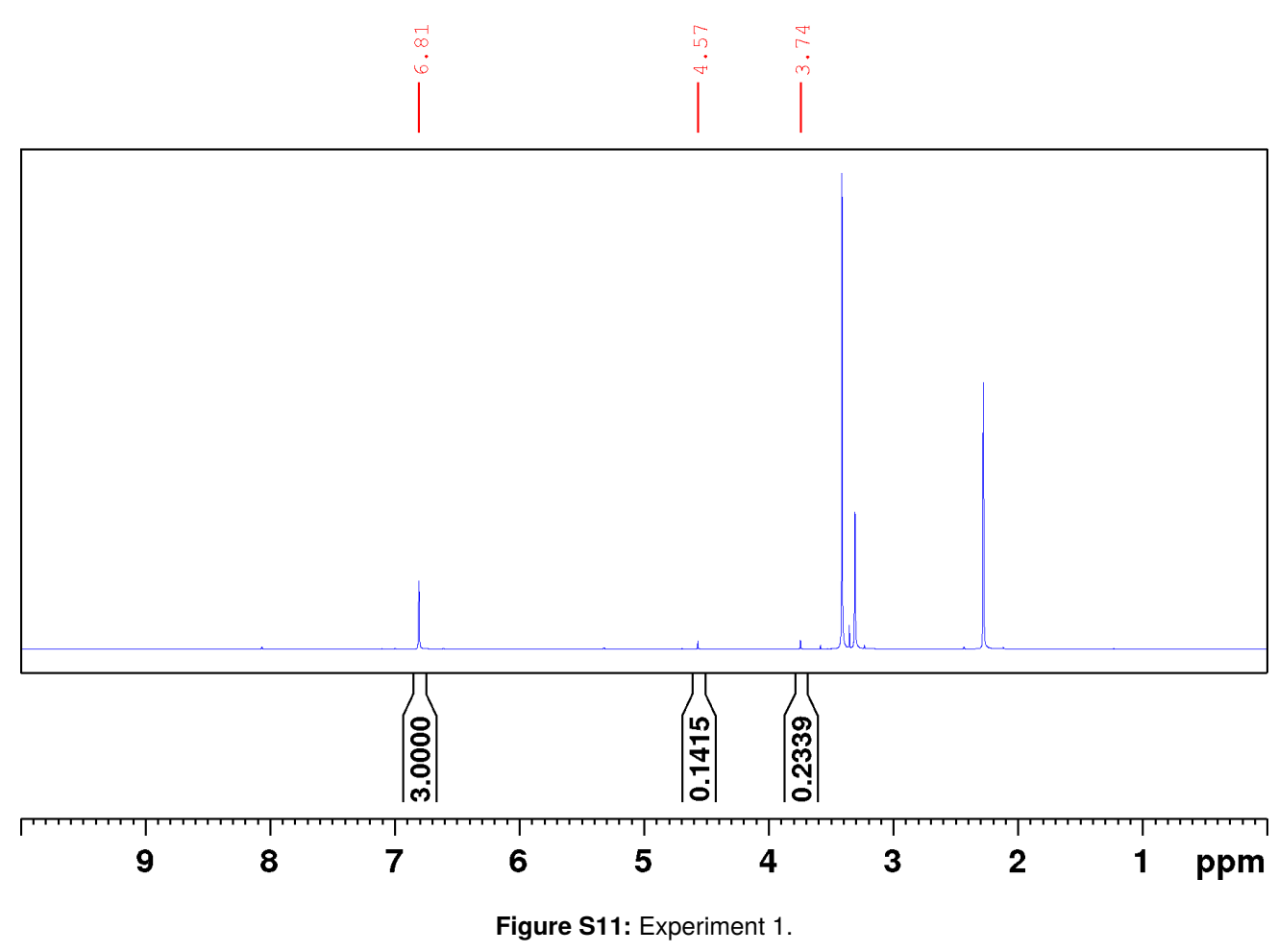




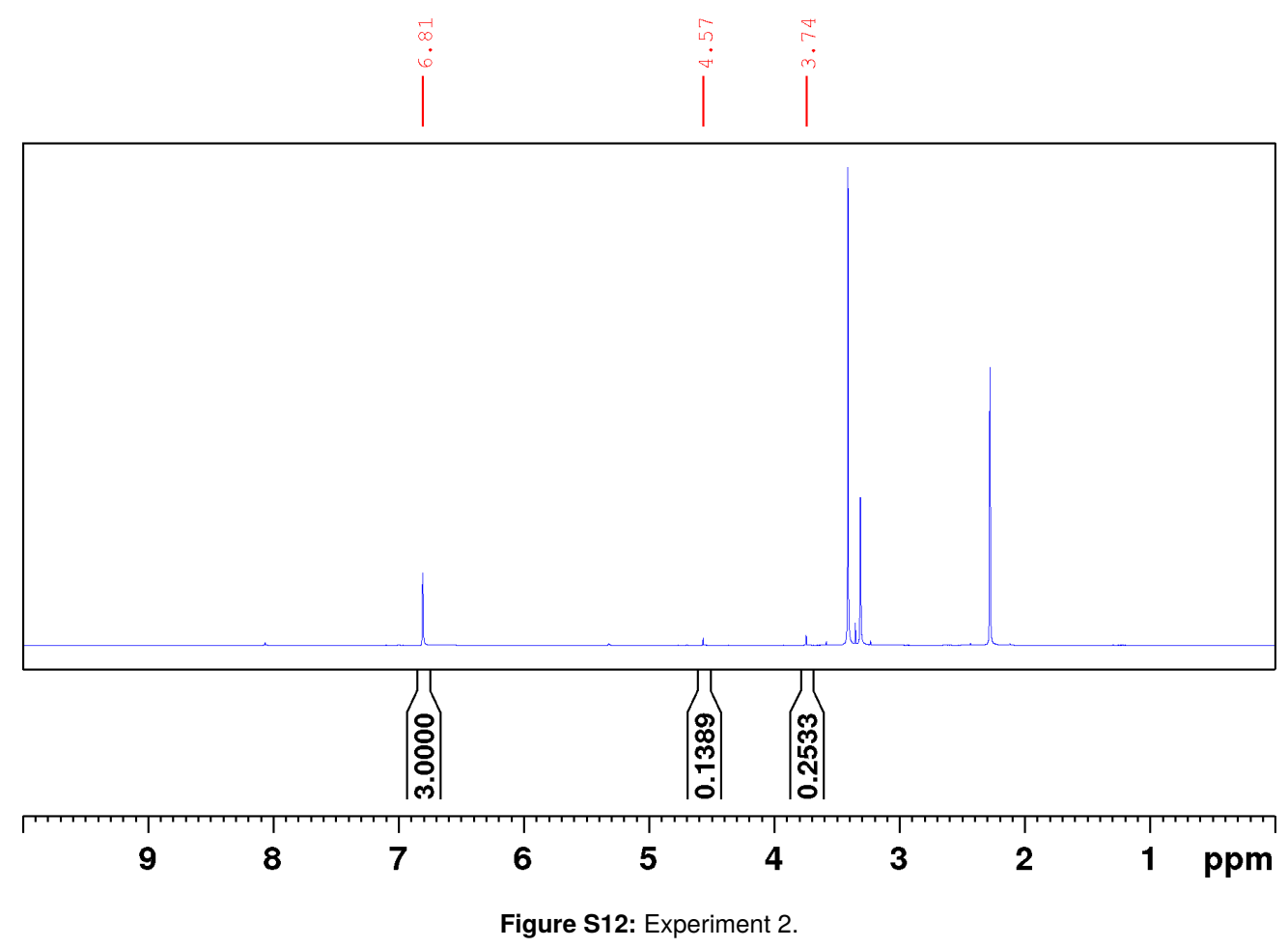




\section{$\mathrm{H}_{2}$ Pressure: $90 \mathrm{bar}$}

$$
\begin{aligned}
T & =90^{\circ} \mathrm{C} & n_{\text {cat }} & =0.375 \mu \mathrm{mol} \\
p_{\mathrm{H} 2} & =90 \mathrm{bar} & n_{\text {add }} & =1.5625 \mu \mathrm{mol} \\
p_{\mathrm{CO} 2} & =20 \mathrm{bar} & \text { add } & =\mathrm{Al}(\mathrm{OTf})_{3} \\
t & =18 \mathrm{~h} & V_{\mathrm{MeOH}} & =0.5 \mathrm{~mL}
\end{aligned}
$$

Table S5: Catalyses results of catalyst $\left[\mathrm{Ru}\left({ }^{\mathrm{Ph}}{ }^{\mathrm{Si}}\right.\right.$-triphos $\left.\left.{ }^{\mathrm{Ph}}\right)(\mathrm{tmm})\right]$ 2a at 90 bar $\mathrm{H}_{2}$ pressure.

\begin{tabular}{lccccc}
\hline & Integral $_{\mathrm{DMM}}$ & TON $_{\mathrm{DMM}}$ & Integral $_{\mathrm{MF}}$ & TON $_{\mathrm{MF}}$ & Ratio \\
\hline Experiment 1 & 0.1300 & 436 & 0.2540 & 568 & 0.77 \\
Experiment 2 & 0.1305 & 438 & 0.2524 & 564 & 0.78 \\
Average & - & $437(1)$ & - & $566(3)$ & $0.77(0.01)$ \\
\hline
\end{tabular}

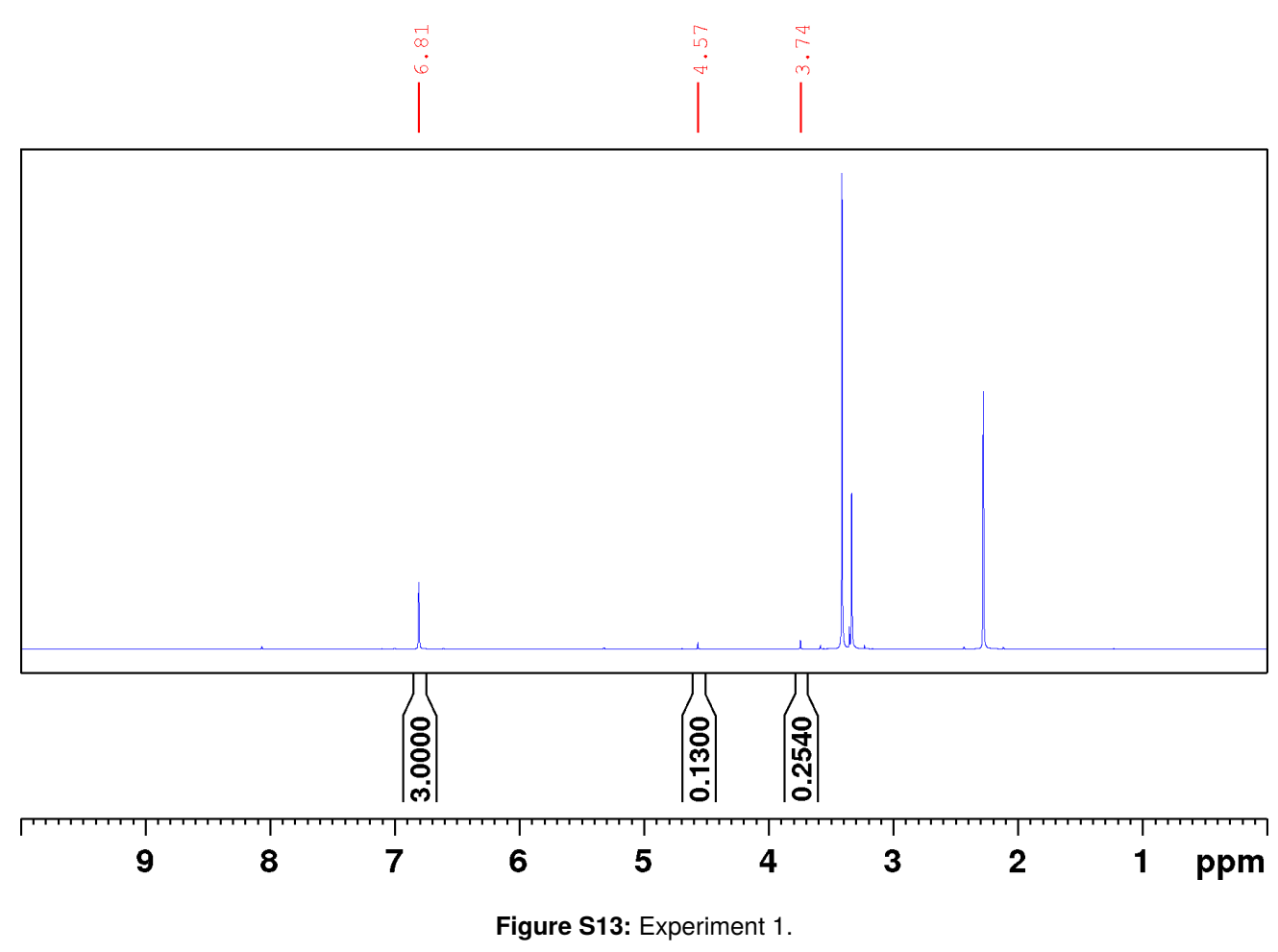




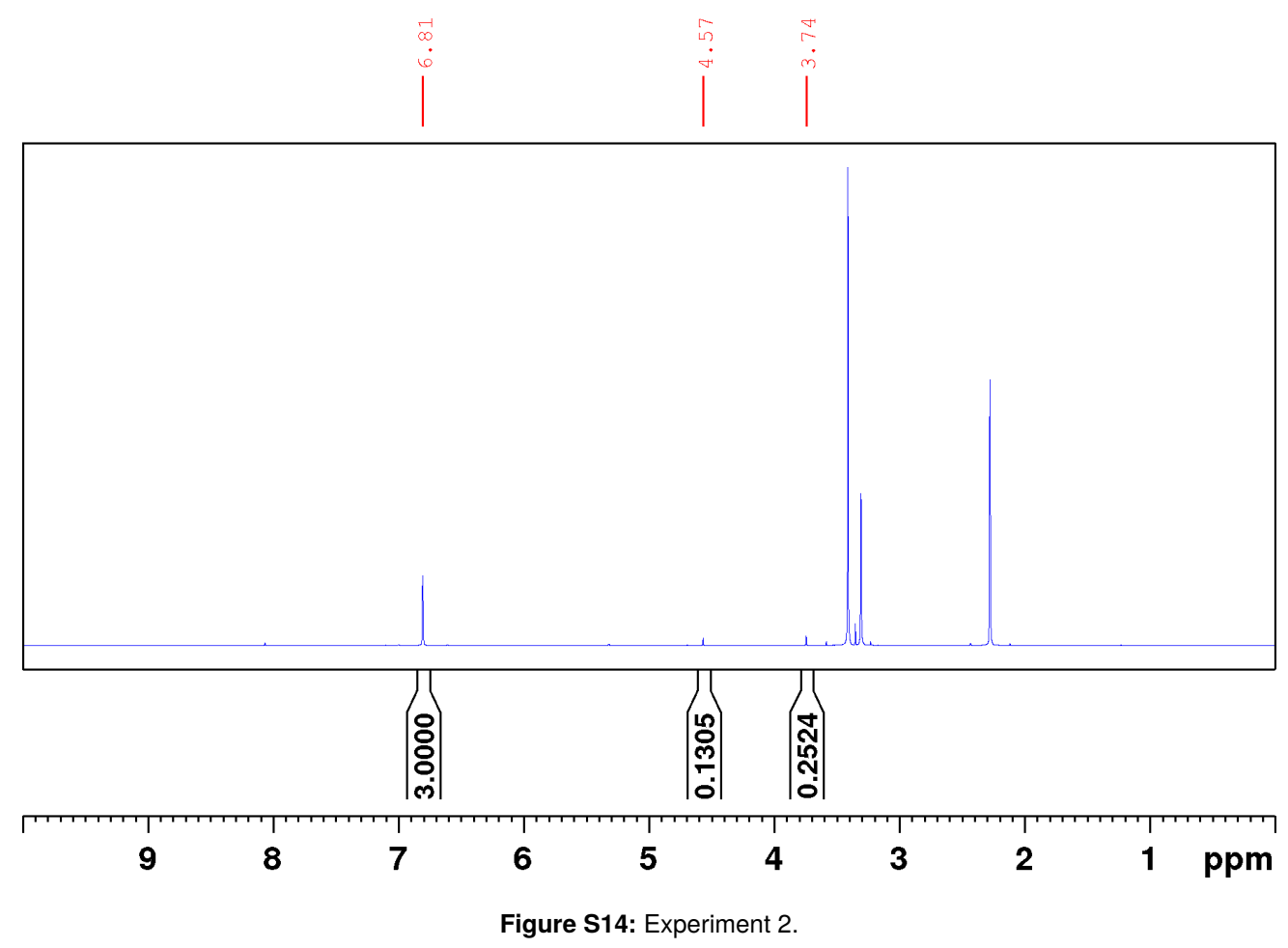


$H_{2}$ Pressure: 100 bar

$$
\begin{aligned}
T & =90^{\circ} \mathrm{C} & n_{\text {cat }} & =0.375 \mu \mathrm{mol} \\
p_{\mathrm{H} 2} & =100 \mathrm{bar} & n_{\text {add }} & =1.5625 \mu \mathrm{mol} \\
p_{\mathrm{CO} 2} & =20 \mathrm{bar} & \text { add } & =\mathrm{Al}(\mathrm{OTf})_{3} \\
t & =18 \mathrm{~h} & V_{\mathrm{MeOH}} & =0.5 \mathrm{~mL}
\end{aligned}
$$

Table S6: Catalyses results of catalyst $\left[\mathrm{Ru}\left({ }^{\mathrm{Ph}} \mathrm{Si}\right.\right.$-triphos $\left.\left.{ }^{\mathrm{Ph}}\right)(\mathrm{tmm})\right]$ 2a at 100 bar $\mathrm{H}_{2}$ pressure.

\begin{tabular}{lccccc}
\hline & Integral $_{\mathrm{DMM}}$ & TON $_{\mathrm{DMM}}$ & Integral $_{\mathrm{MF}}$ & TON $_{\mathrm{MF}}$ & Ratio \\
\hline Experiment 1 & 0.1423 & 477 & 0.2831 & 633 & 0.75 \\
Experiment 2 & 0.1328 & 446 & 0.2740 & 613 & 0.73 \\
Average & - & $462(22)$ & - & $623(14)$ & $0.74(0.02)$ \\
\hline
\end{tabular}

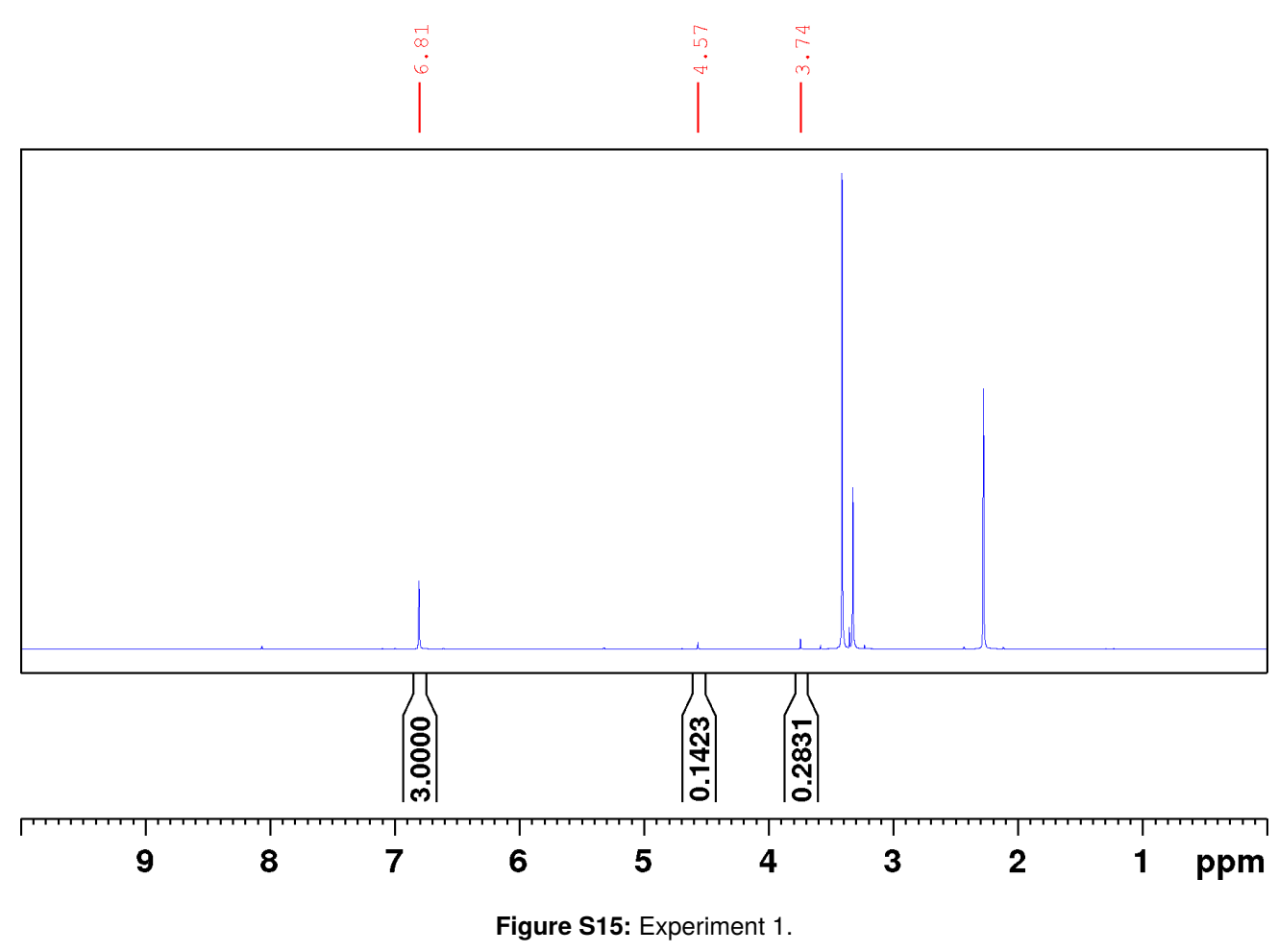




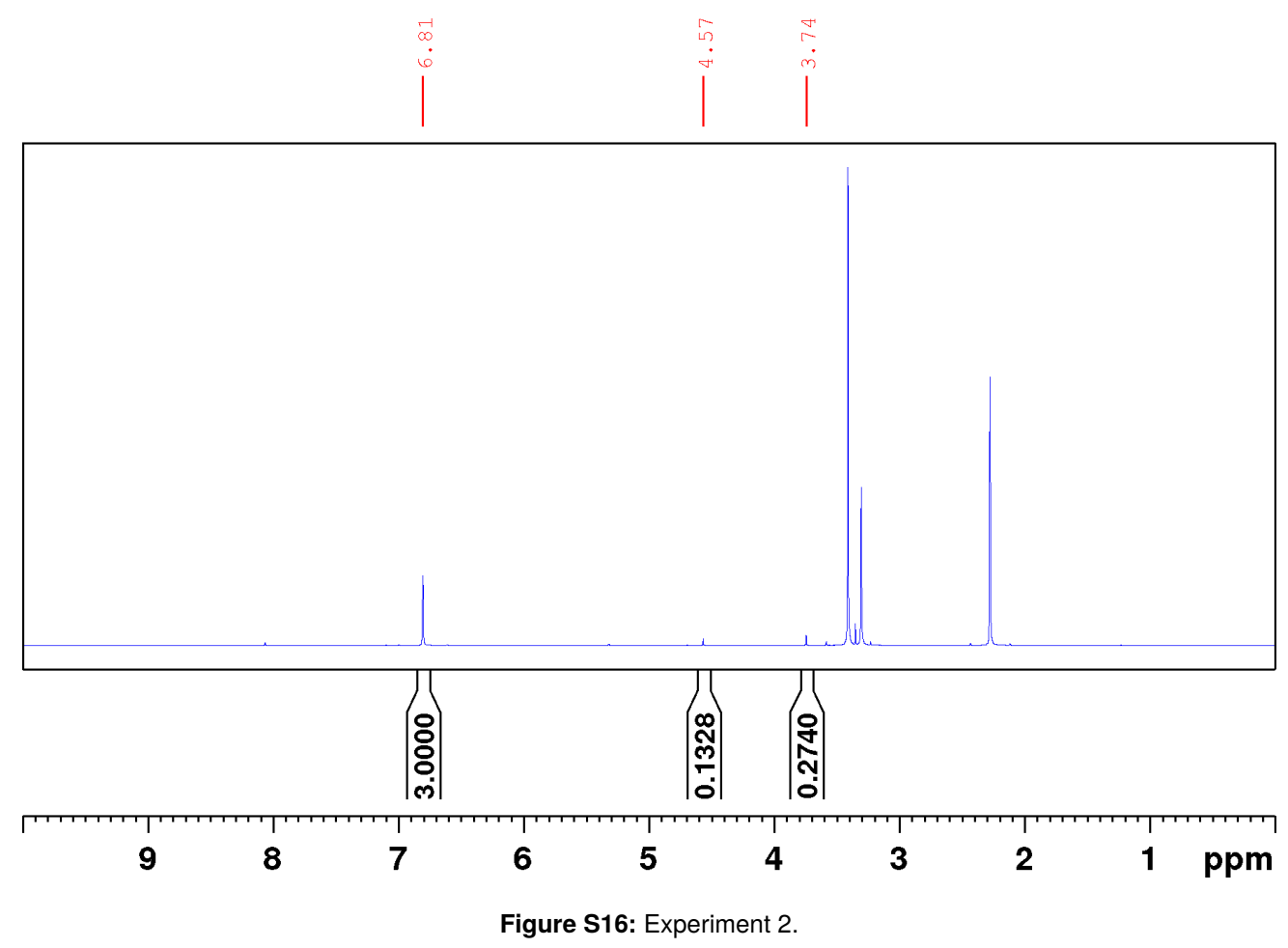


$\mathrm{CO}_{2}$ Pressure: $10 \mathrm{bar}$

$$
\begin{array}{rlrl}
T & =90^{\circ} \mathrm{C} & n_{\text {cat }} & =0.375 \mu \mathrm{mol} \\
p_{\mathrm{H} 2} & =90 \mathrm{bar} & n_{\text {add }} & =1.5625 \mu \mathrm{mol} \\
p_{\mathrm{CO} 2} & =10 \mathrm{bar} & \mathrm{add} & =\mathrm{Al}(\mathrm{OTf})_{3} \\
t & =18 \mathrm{~h} & V_{\mathrm{MeOH}} & =0.5 \mathrm{~mL}
\end{array}
$$

Table S7: Catalyses results of catalyst $\left[\mathrm{Ru}\left({ }^{\mathrm{Ph}} \mathrm{Si}\right.\right.$-triphos $\left.\left.{ }^{\mathrm{Ph}}\right)(\mathrm{tmm})\right] \mathbf{2 a}$ at $10 \mathrm{bar} \mathrm{CO}_{2}$ pressure.

\begin{tabular}{lccccc}
\hline & Integral $_{\mathrm{DMM}}$ & TON $_{\mathrm{DMM}}$ & Integral $_{\mathrm{MF}}$ & TON $_{\mathrm{MF}}$ & Ratio \\
\hline Experiment 1 & 0.1146 & 384 & 0.1070 & 239 & 1.61 \\
Experiment 2 & 0.1151 & 386 & 0.1117 & 250 & 1.55 \\
Average & - & $385(1)$ & - & $245(7)$ & $1.58(0.04)$ \\
\hline
\end{tabular}

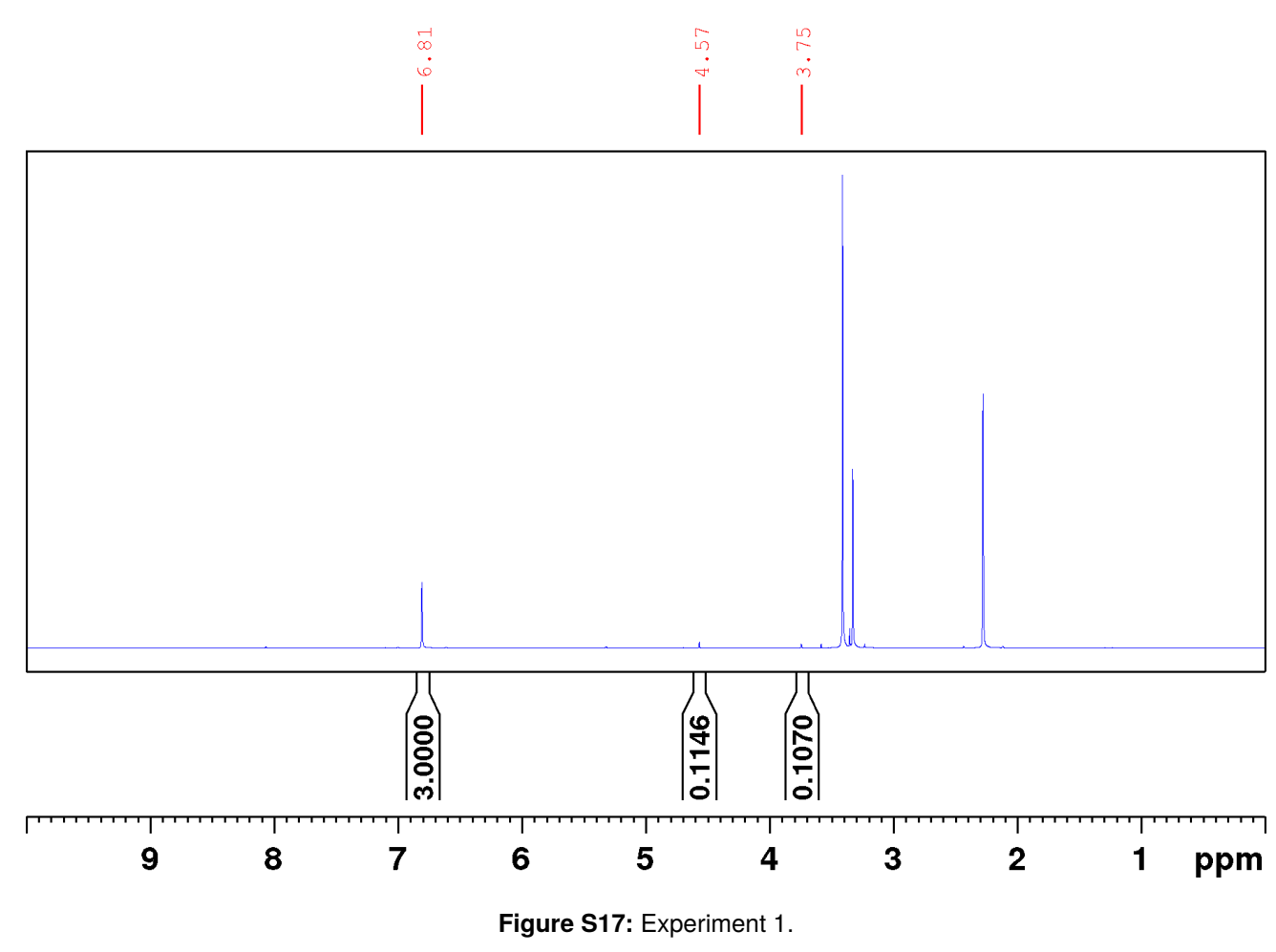









\section{$\mathrm{CO}_{2}$ Pressure: 20 bar}

$$
\begin{aligned}
T & =90^{\circ} \mathrm{C} & n_{\text {cat }} & =0.375 \mu \mathrm{mol} \\
p_{\mathrm{H} 2} & =90 \mathrm{bar} & n_{\text {add }} & =1.5625 \mu \mathrm{mol} \\
p_{\mathrm{CO} 2} & =20 \mathrm{bar} & \text { add } & =\mathrm{Al}(\mathrm{OTf})_{3} \\
t & =18 \mathrm{~h} & V_{\mathrm{MeOH}} & =0.5 \mathrm{~mL}
\end{aligned}
$$

Table S8: Catalyses results of catalyst $\left[\mathrm{Ru}\left({ }^{\mathrm{Ph}} \mathrm{Si}\right.\right.$-triphos $\left.\left.{ }^{\mathrm{Ph}}\right)(\mathrm{tmm})\right] \mathbf{2 a}$ at 20 bar $\mathrm{CO}_{2}$ pressure.

\begin{tabular}{lccccc}
\hline & Integral $_{\mathrm{DMM}}$ & $\mathrm{TON}_{\mathrm{DMM}}$ & Integral $_{\mathrm{MF}}$ & $\mathrm{TON}_{\mathrm{MF}}$ & Ratio \\
\hline Experiment 1 & 0.1300 & 436 & 0.2540 & 568 & 0.77 \\
Experiment 2 & 0.1305 & 438 & 0.2524 & 564 & 0.78 \\
Average & - & $437(1)$ & - & $566(3)$ & $0.77(0.01)$ \\
\hline
\end{tabular}

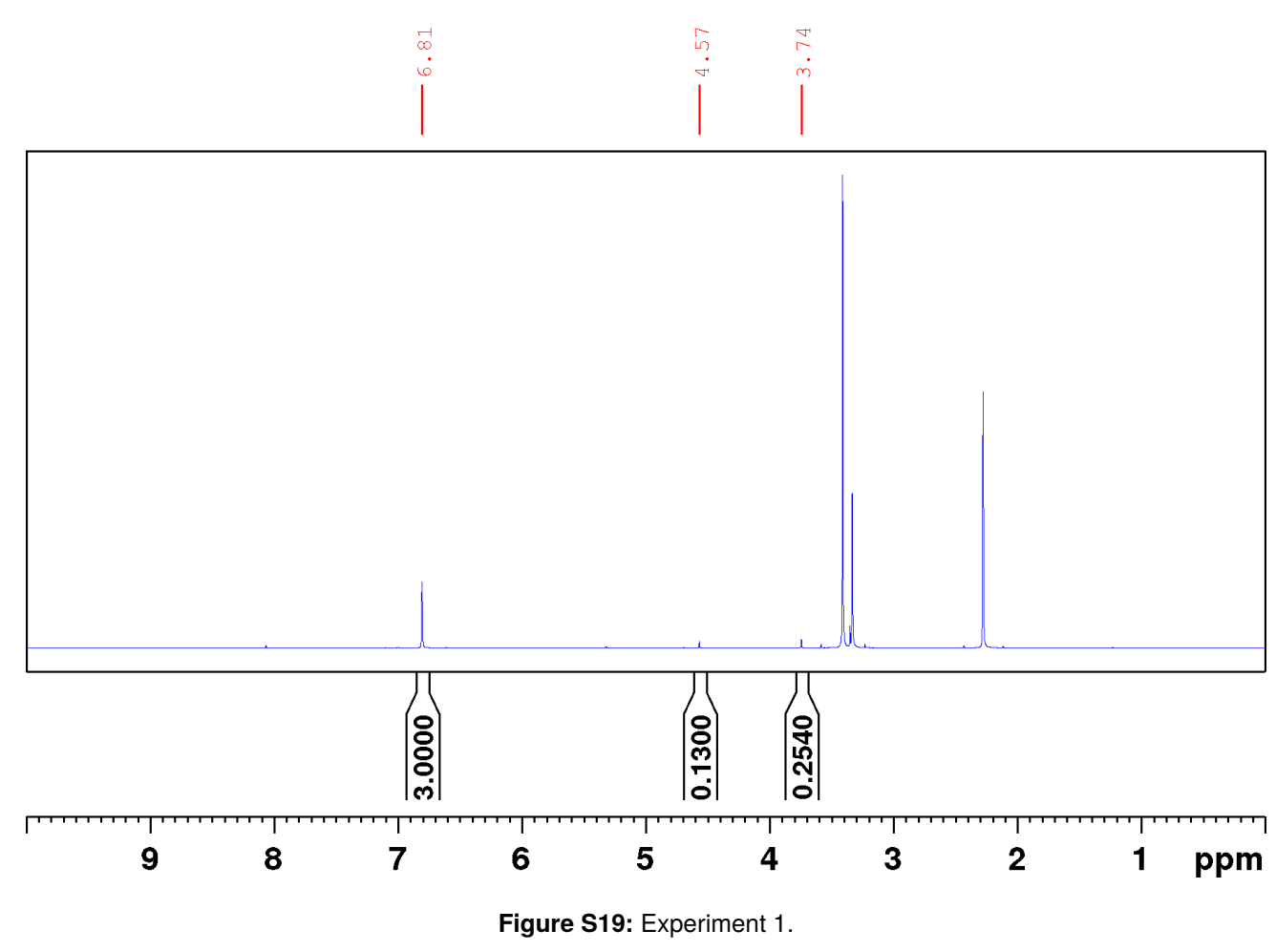




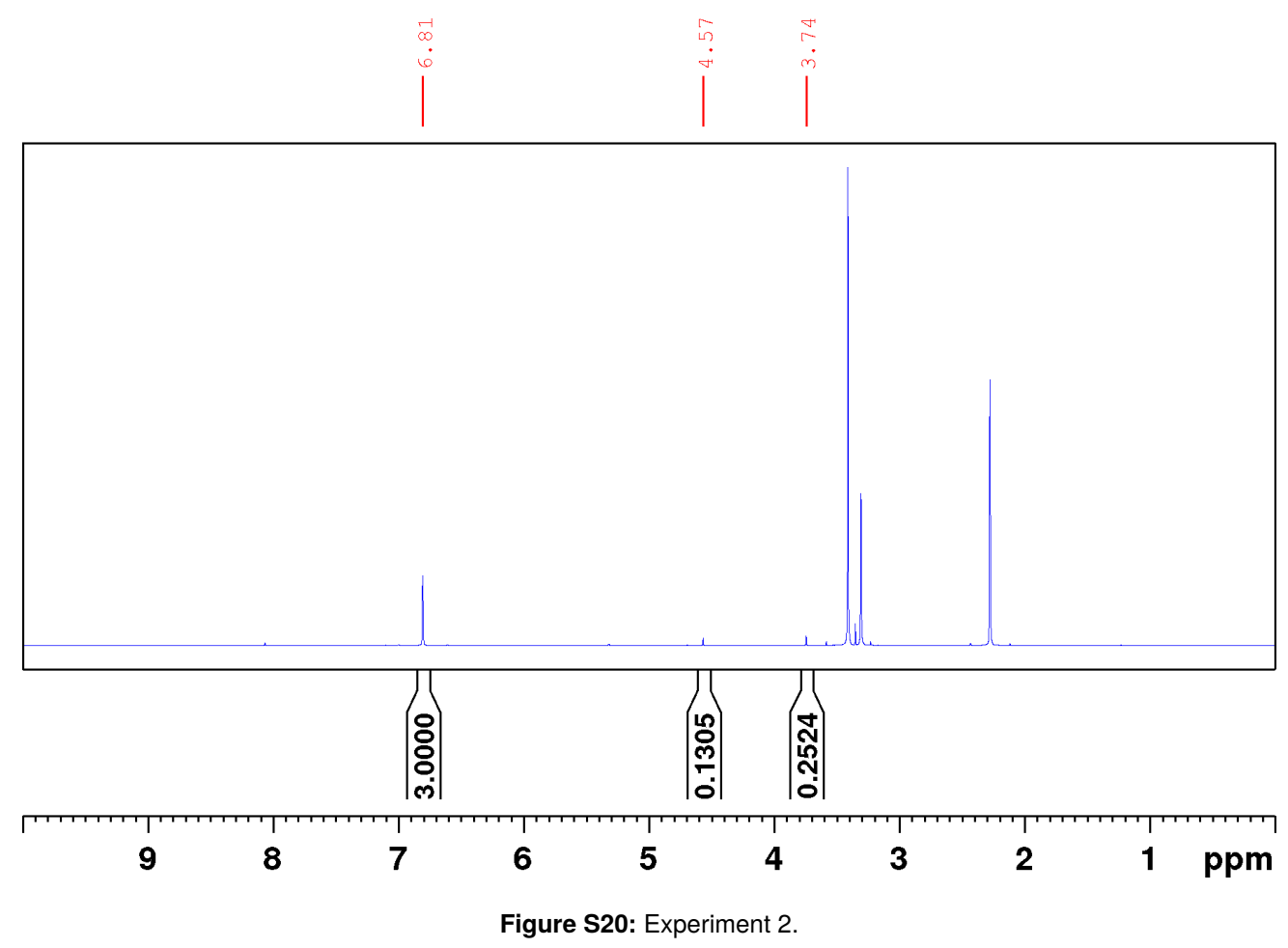


$\mathrm{CO}_{2}$ Pressure: $30 \mathrm{bar}$

$$
\begin{aligned}
T & =90^{\circ} \mathrm{C} & n_{\text {cat }} & =0.375 \mu \mathrm{mol} \\
p_{\mathrm{H} 2} & =90 \mathrm{bar} & n_{\text {add }} & =1.5625 \mu \mathrm{mol} \\
p_{\mathrm{CO} 2} & =30 \mathrm{bar} & \text { add } & =\mathrm{Al}(\mathrm{OTf})_{3} \\
t & =18 \mathrm{~h} & V_{\mathrm{MeOH}} & =0.5 \mathrm{~mL}
\end{aligned}
$$

Table S9: Catalyses results of catalyst $\left[\mathrm{Ru}\left({ }^{\mathrm{Ph}} \mathrm{Si}\right.\right.$-triphos $\left.\left.{ }^{\mathrm{Ph}}\right)(\mathrm{tmm})\right] 2 \mathrm{2a}$ at 30 bar $\mathrm{CO}_{2}$ pressure.

\begin{tabular}{lccccc}
\hline & Integral $_{\mathrm{DMM}}$ & $\mathrm{TON}_{\mathrm{DMM}}$ & Integral $_{\mathrm{MF}}$ & $\mathrm{TON}_{\mathrm{MF}}$ & Ratio \\
\hline Experiment 1 & 0.1406 & 472 & 0.3003 & 672 & 0.70 \\
Experiment 2 & 0.1171 & 393 & 0.2848 & 637 & 0.62 \\
Average & - & $433(56)$ & - & $655(25)$ & $0.66(0.06)$ \\
\hline
\end{tabular}

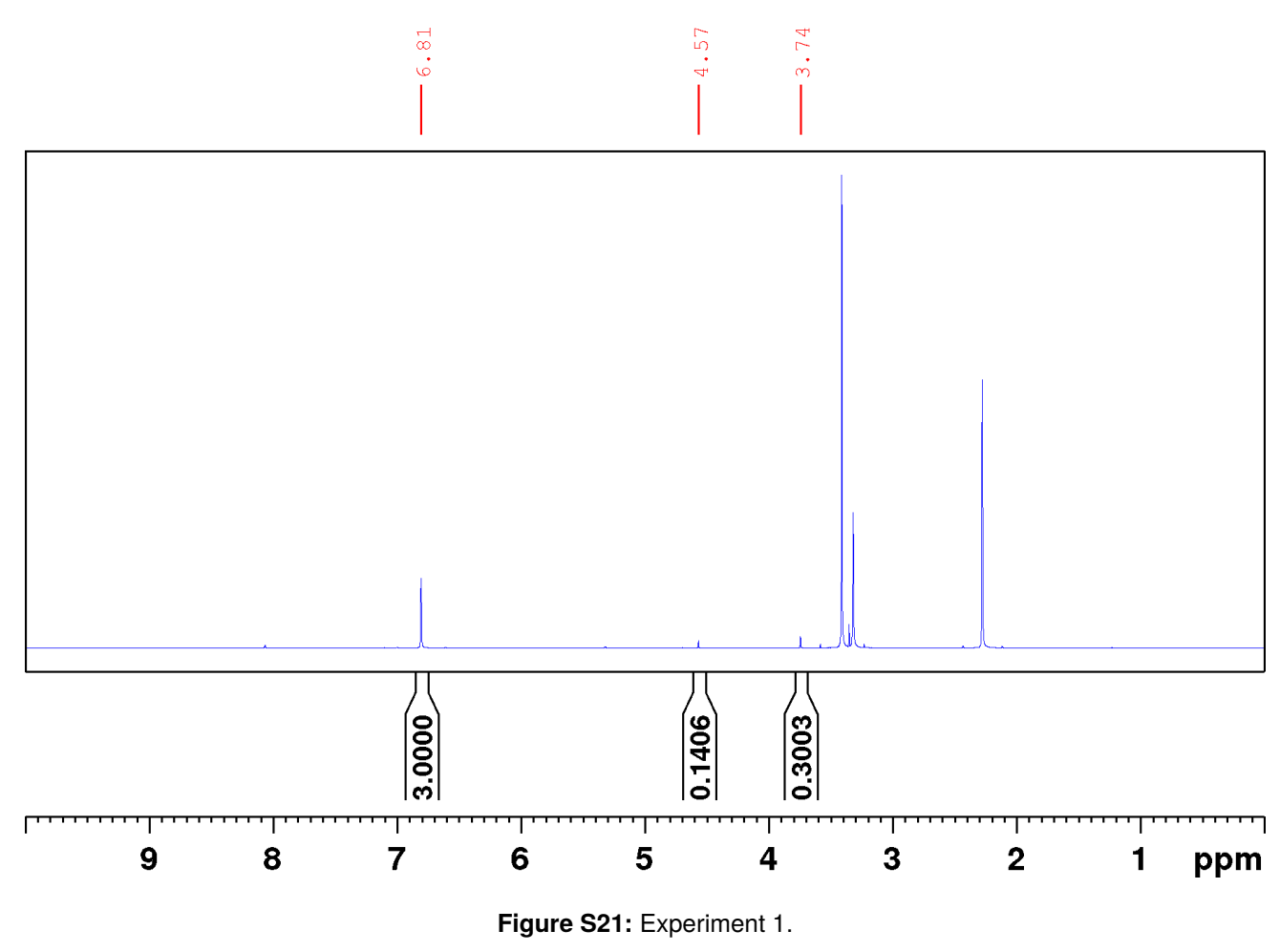




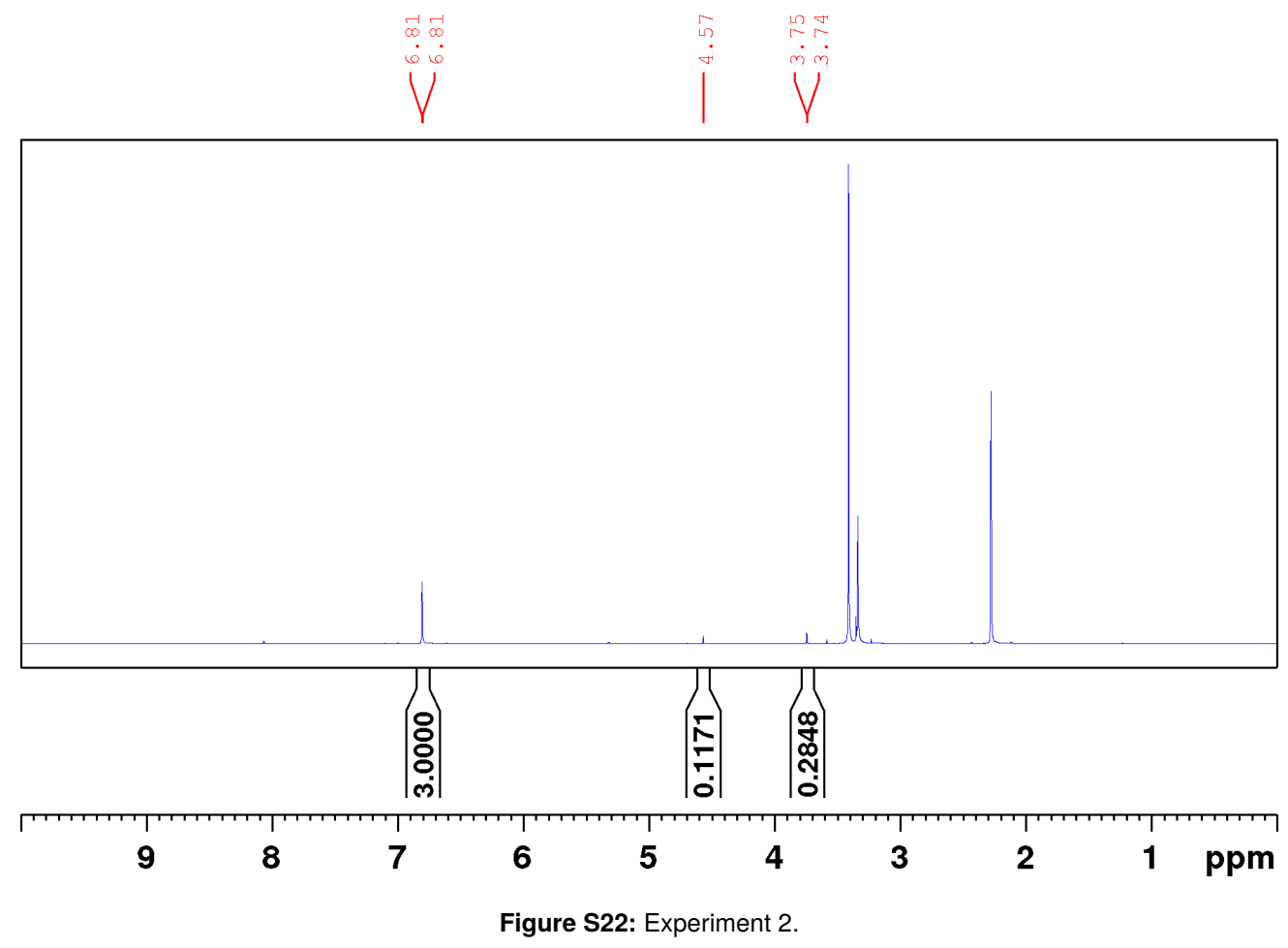




\section{Catalyst Loading: $0.1875 \mu \mathrm{mol}$}

$$
\begin{aligned}
T & =90^{\circ} \mathrm{C} & n_{\text {cat }} & =0.1875 \mu \mathrm{mol} \\
p_{\mathrm{H} 2} & =90 \mathrm{bar} & n_{\text {add }} & =0.78125 \mu \mathrm{mol} \\
p_{\mathrm{CO} 2} & =20 \mathrm{bar} & \text { add } & =\mathrm{Al}(\mathrm{OTf})_{3} \\
t & =18 \mathrm{~h} & V_{\mathrm{MeOH}} & =0.5 \mathrm{~mL}
\end{aligned}
$$

\begin{tabular}{|c|c|c|c|c|c|}
\hline & Integral $_{\mathrm{DMM}}$ & $\mathrm{TON}_{\mathrm{DMM}}$ & Integral $_{\mathrm{MF}}$ & $\mathrm{TON}_{\mathrm{MF}}$ & Ratio \\
\hline Experiment 1 & 0.0835 & 560 & 0.2927 & 1309 & 0.43 \\
\hline Experiment 2 & 0.0846 & 568 & 0.3111 & 1391 & 0.41 \\
\hline Average & - & $564(6)$ & - & $1350(58)$ & $0.42(0.01)$ \\
\hline
\end{tabular}

Table S10: Catalyses results of catalyst $\left[\mathrm{Ru}\left({ }^{\mathrm{Ph}} \mathrm{Si}\right.\right.$-triphos $\left.\left.{ }^{\mathrm{Ph}}\right)(\mathrm{tmm})\right]$ 2a at a catalyst loading of $0.1875 \mu \mathrm{mol}$.

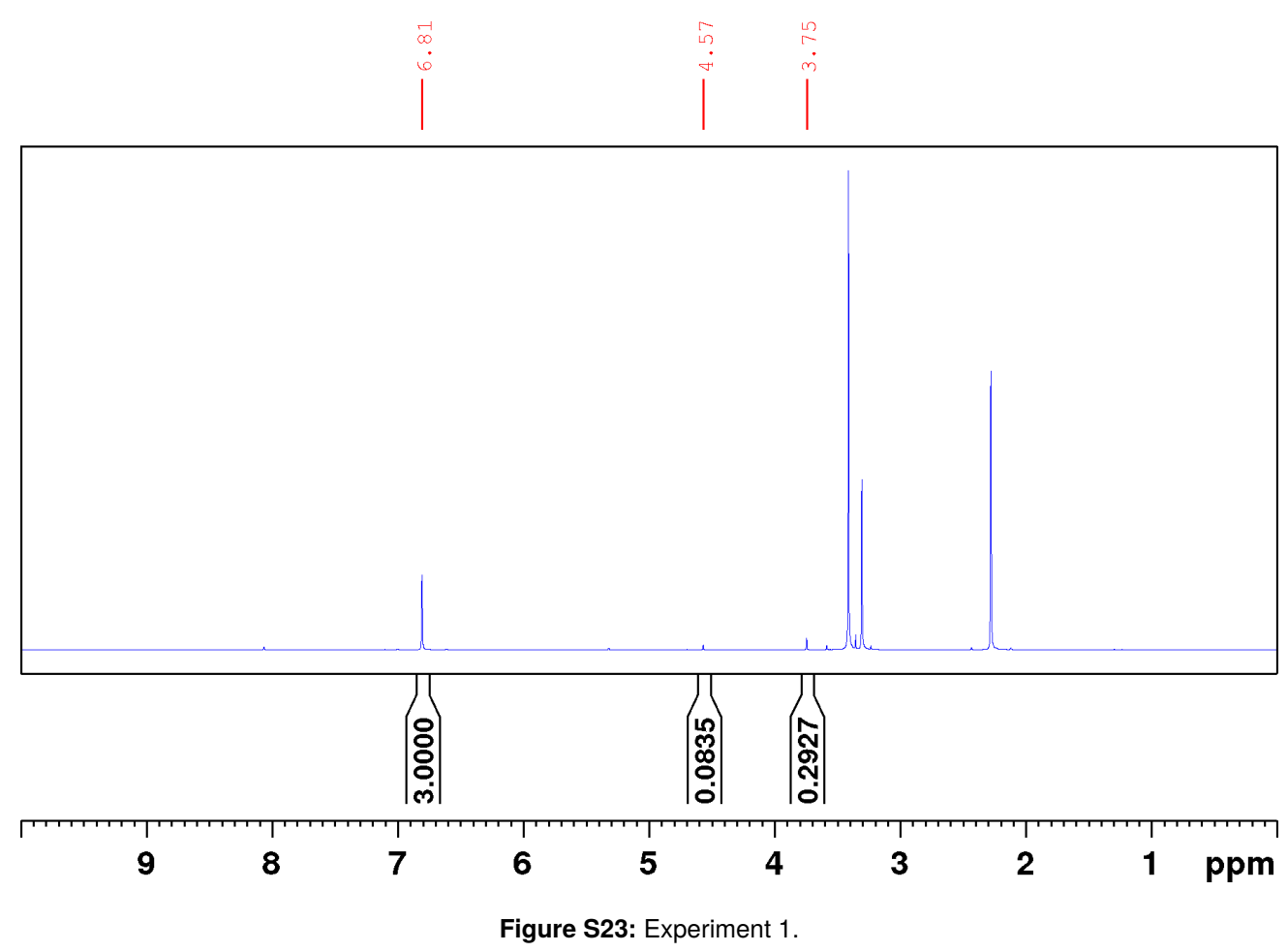




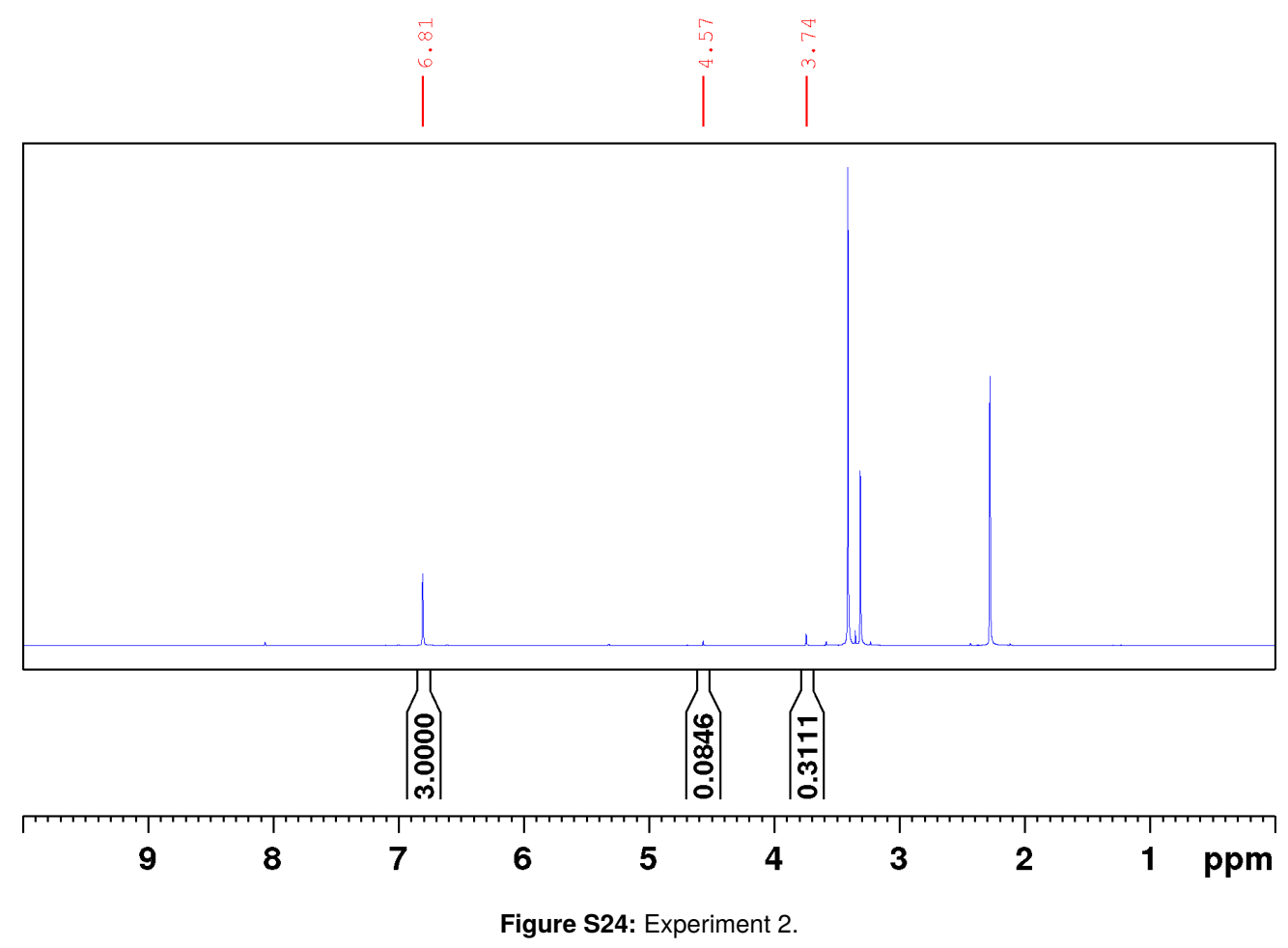




\section{Catalyst Loading: $0.375 \mu \mathrm{mol}$}

$$
\begin{aligned}
T & =90^{\circ} \mathrm{C} & n_{\text {cat }} & =0.375 \mu \mathrm{mol} \\
p_{\mathrm{H} 2} & =90 \mathrm{bar} & n_{\text {add }} & =1.5625 \mu \mathrm{mol} \\
p_{\mathrm{CO} 2} & =20 \mathrm{bar} & \text { add } & =\mathrm{Al}(\mathrm{OTf})_{3} \\
t & =18 \mathrm{~h} & V_{\mathrm{MeOH}} & =0.5 \mathrm{~mL}
\end{aligned}
$$

Table S11: Catalyses results of catalyst $\left[\mathrm{Ru}\left({ }^{\mathrm{Ph}} \mathrm{Si}\right.\right.$-triphos $\left.\left.{ }^{\mathrm{Ph}}\right)(\mathrm{tmm})\right]$ 2a at a catalyst loading of $0.375 \mu \mathrm{mol}$.

\begin{tabular}{lccccc}
\hline & Integral $_{\mathrm{DMM}}$ & $\mathrm{TON}_{\mathrm{DMM}}$ & Integral $_{\mathrm{MF}}$ & $\mathrm{TON}_{\mathrm{MF}}$ & Ratio \\
\hline Experiment 1 & 0.1300 & 436 & 0.2540 & 568 & 0.77 \\
Experiment 2 & 0.1305 & 438 & 0.2524 & 564 & 0.78 \\
Average & - & $437(1)$ & - & $566(3)$ & $0.77(0.01)$ \\
\hline
\end{tabular}

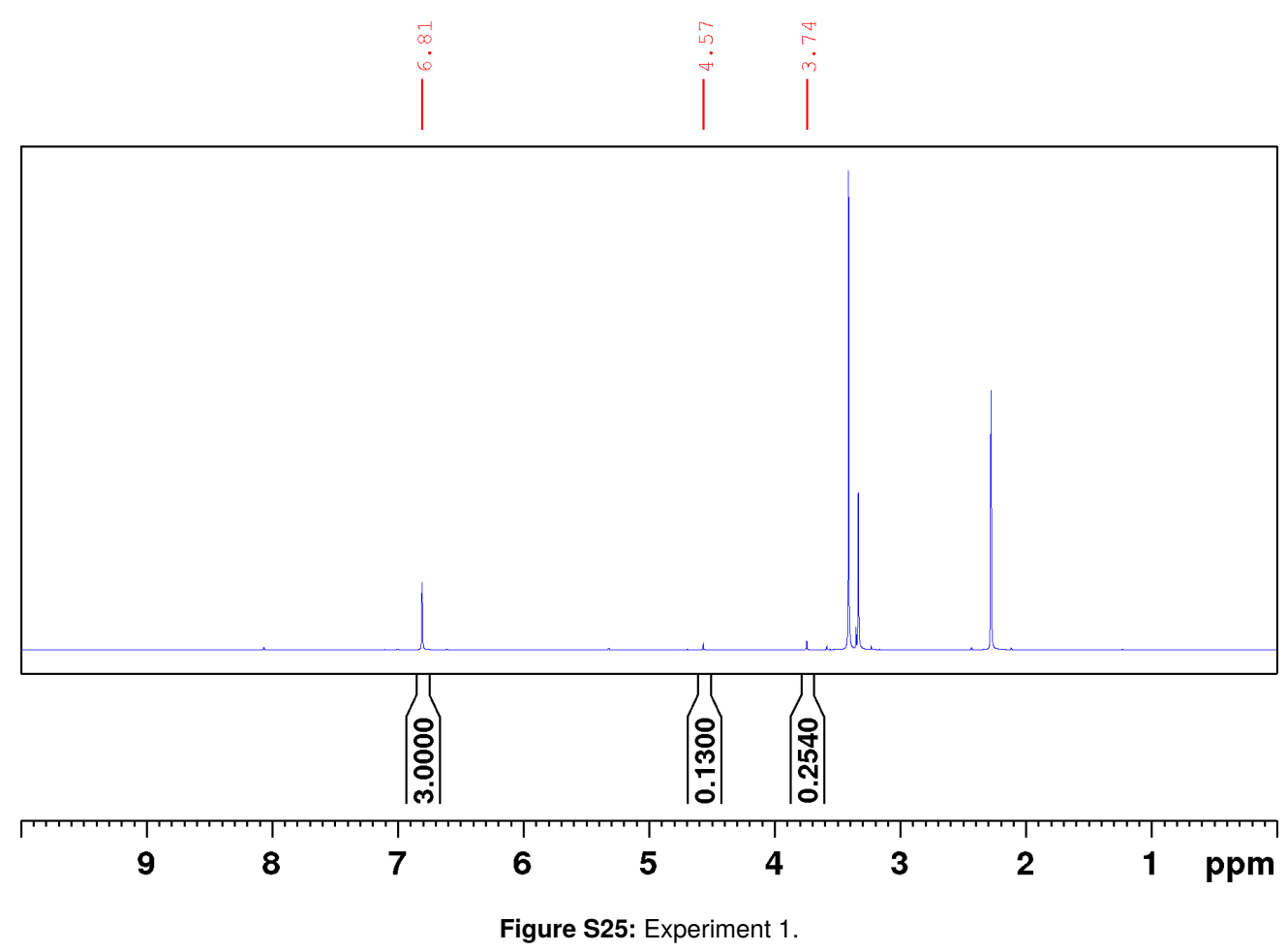




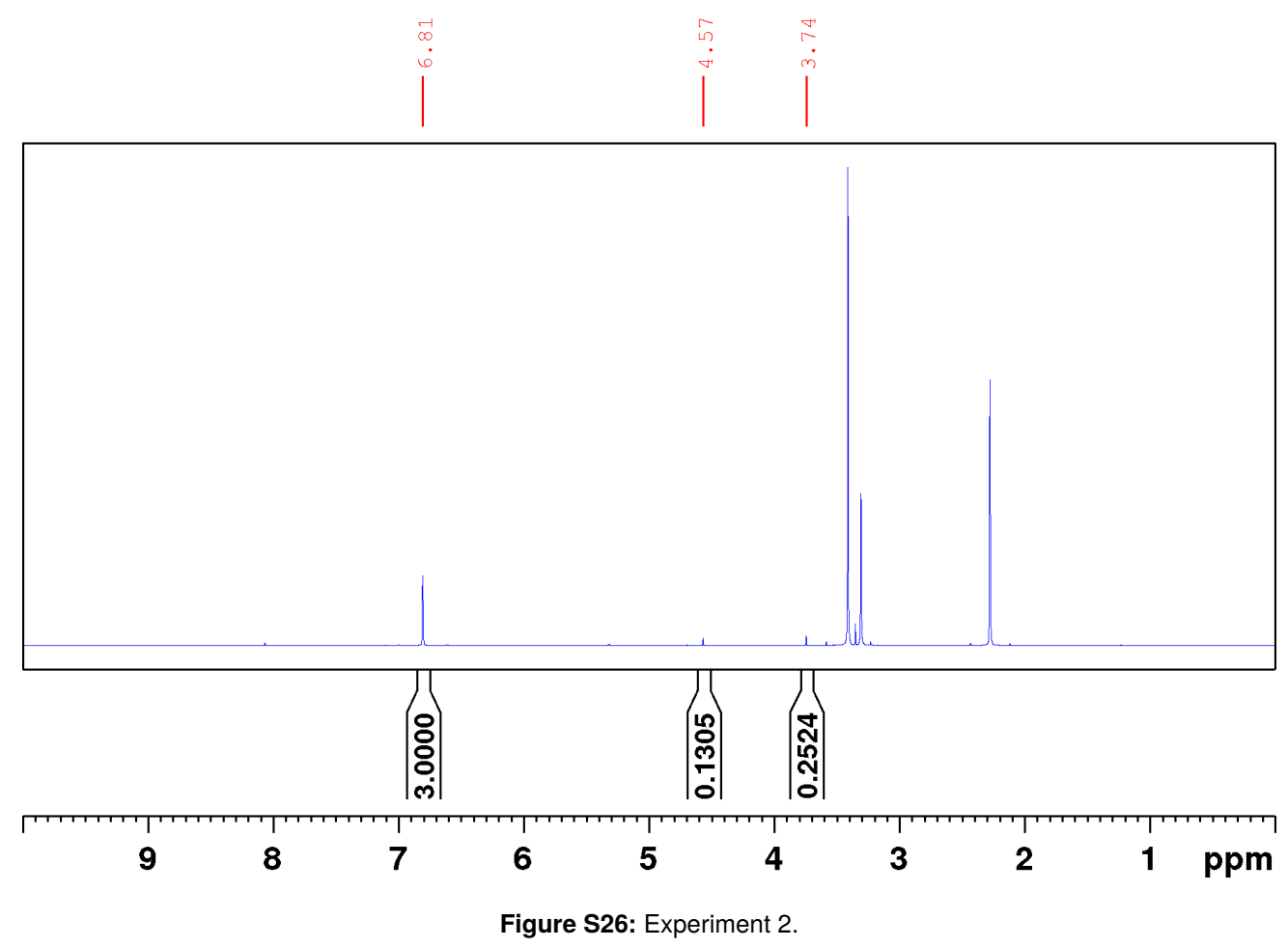




\section{Catalyst Loading: $0.75 \mu \mathrm{mol}$}

$$
\begin{aligned}
T & =90^{\circ} \mathrm{C} & n_{\text {cat }} & =0.75 \mu \mathrm{mol} \\
p_{\mathrm{H} 2} & =90 \mathrm{bar} & n_{\mathrm{add}} & =3.125 \mu \mathrm{mol} \\
p_{\mathrm{CO} 2} & =20 \mathrm{bar} & \text { add } & =\mathrm{Al}(\mathrm{OTf})_{3} \\
t & =18 \mathrm{~h} & V_{\mathrm{MeOH}} & =0.5 \mathrm{~mL}
\end{aligned}
$$

Table S12: Catalyses results of catalyst $\left[\mathrm{Ru}\left({ }^{\mathrm{Ph}} \mathrm{Si}\right.\right.$-triphos $\left.\left.{ }^{\mathrm{Ph}}\right)(\mathrm{tmm})\right]$ 2a at a catalyst loading of $0.75 \mu \mathrm{mol}$.

\begin{tabular}{lccccc}
\hline & Integral $_{\text {DMM }}$ & TON $_{\text {DMM }}$ & Integral $_{\mathrm{MF}}$ & TON $_{\mathrm{MF}}$ & Ratio \\
\hline Experiment 1 & 0.2002 & 336 & 0.1646 & 184 & 1.82 \\
Experiment 2 & 0.1963 & 329 & 0.1662 & 186 & 1.77 \\
Average & - & $333(5)$ & - & $185(1)$ & $1.80(0.04)$ \\
\hline
\end{tabular}

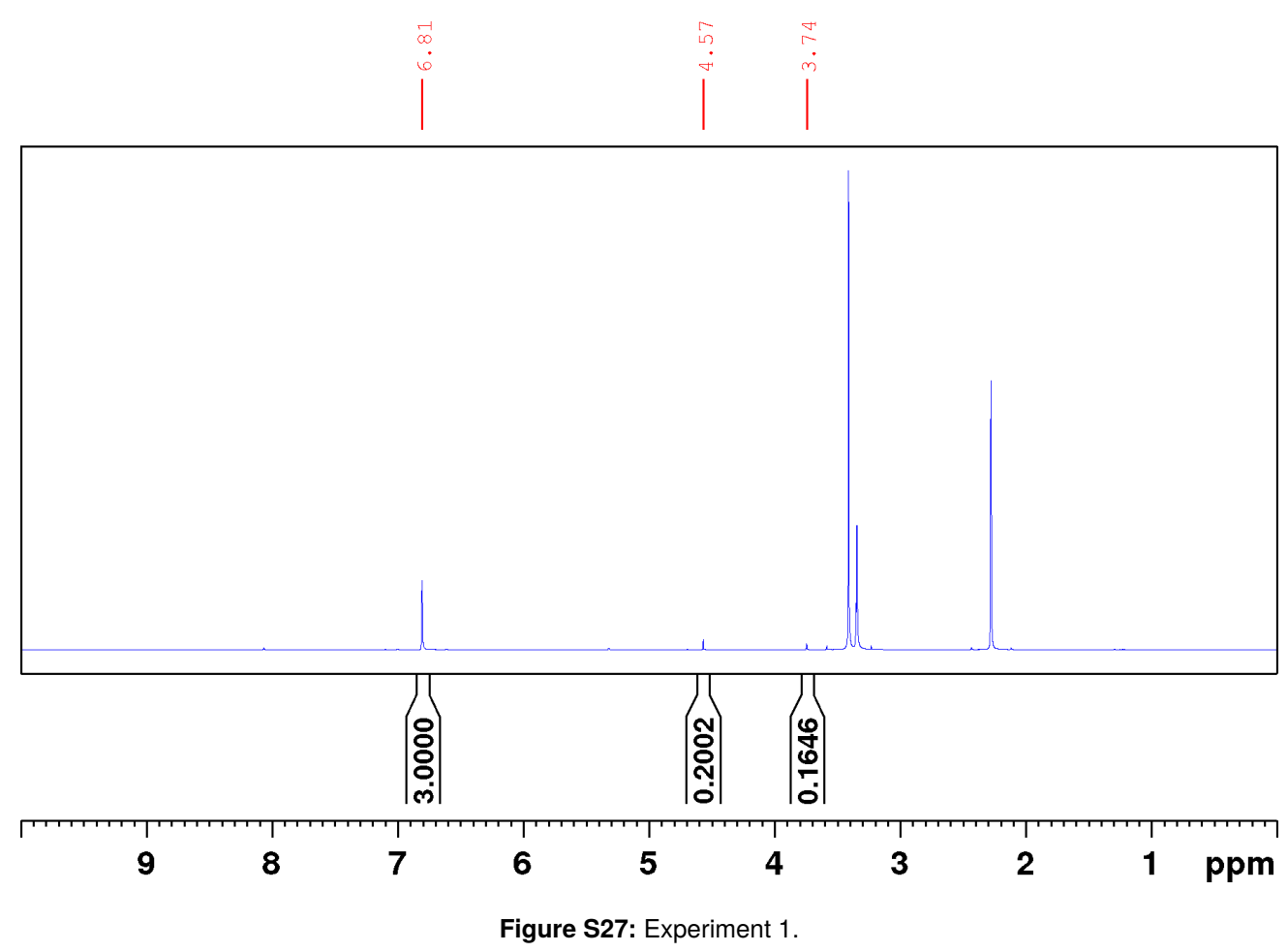




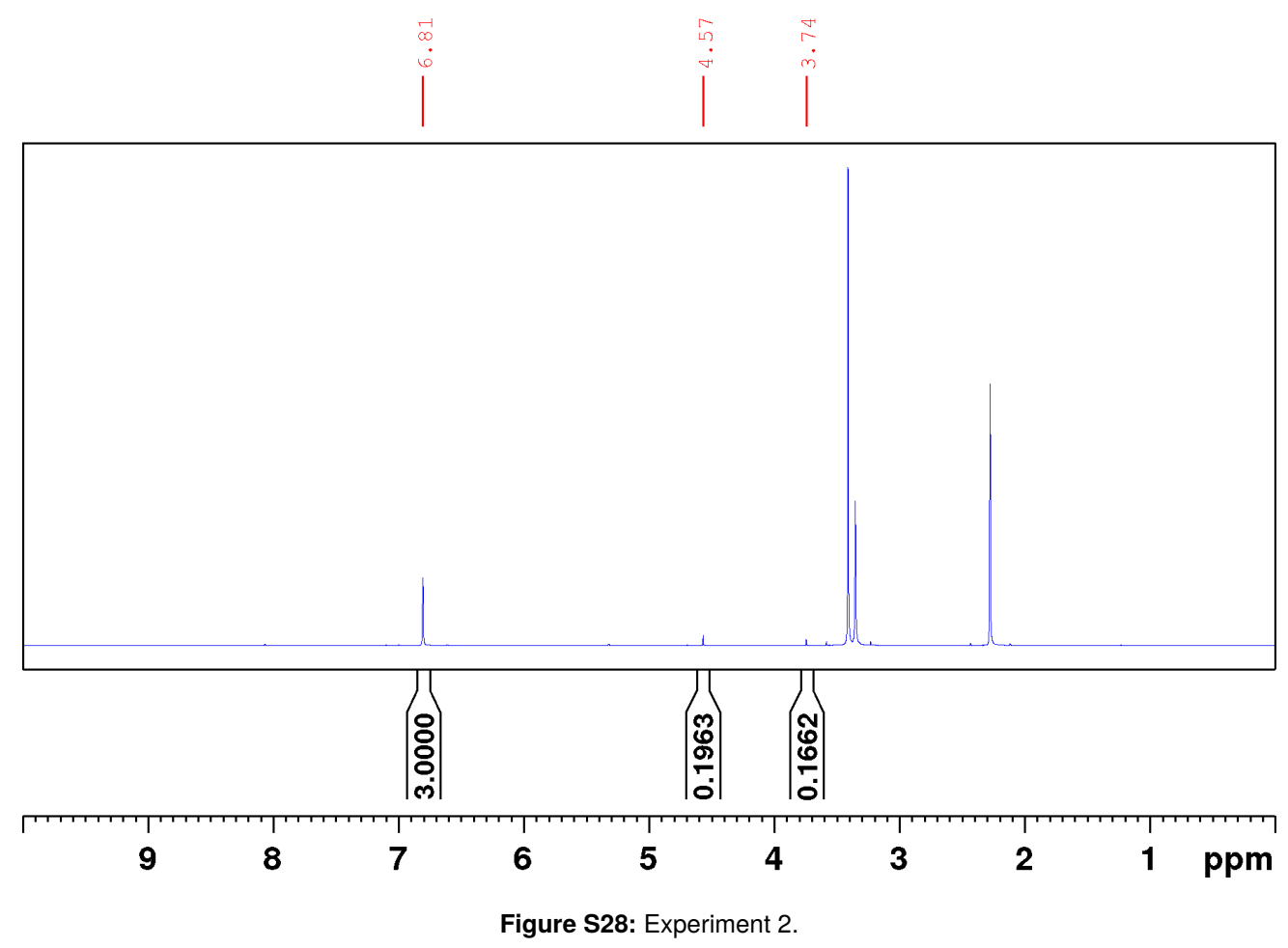




\section{Additive Loading: $0.78125 \mu \mathrm{mol}$}

$$
\begin{aligned}
\mathrm{T} & =90^{\circ} \mathrm{C} & n_{\mathrm{cat}} & =0.375 \mu \mathrm{mol} \\
p_{\mathrm{H} 2} & =90 \mathrm{bar} & n_{\mathrm{add}} & =0.78125 \mu \mathrm{mol} \\
p_{\mathrm{CO} 2} & =20 \mathrm{bar} & \text { add } & =\mathrm{Al}(\mathrm{OTf})_{3} \\
t & =18 \mathrm{~h} & V_{\mathrm{MeOH}} & =0.5 \mathrm{~mL}
\end{aligned}
$$

Table S13: Catalyses results of catalyst $\left[\mathrm{Ru}\left({ }^{\mathrm{Ph}} \mathrm{Si}\right.\right.$-triphos $\left.\left.{ }^{\mathrm{Ph}}\right)(\mathrm{tmm})\right] 2$ 2a at an additive loading of $0.78125 \mu \mathrm{mol}$.

\begin{tabular}{lccccc}
\hline & Integral $_{\mathrm{DMM}}$ & $\mathrm{TON}_{\mathrm{DMM}}$ & Integral $_{\mathrm{MF}}$ & $\mathrm{TON}_{\mathrm{MF}}$ & Ratio \\
\hline Experiment 1 & 0.0796 & 267 & 0.2782 & 622 & 0.43 \\
Experiment 2 & 0.0799 & 268 & 0.2785 & 623 & 0.43 \\
Average & - & $268(1)$ & - & $623(1)$ & $0.43(0.00)$ \\
\hline
\end{tabular}

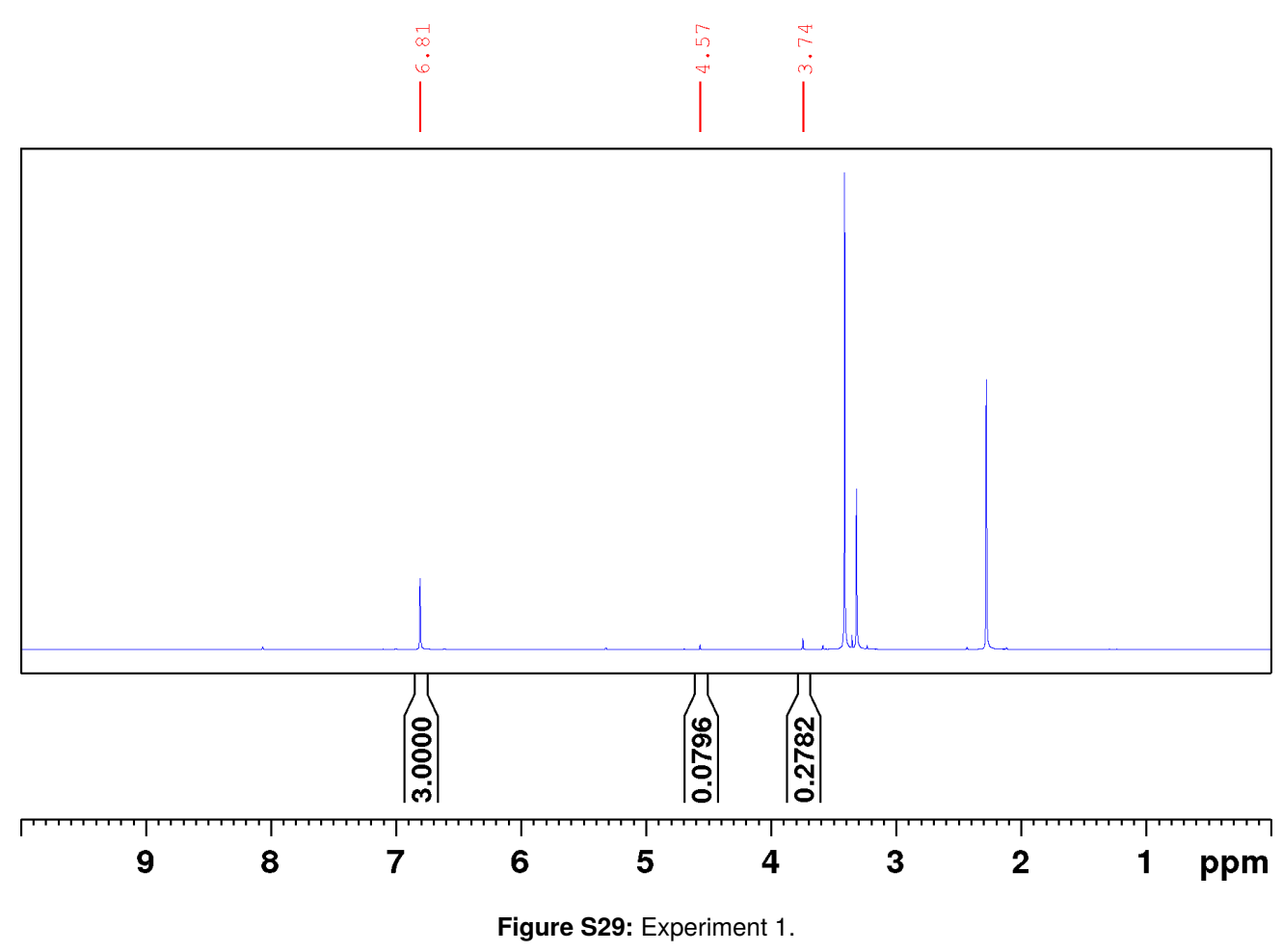




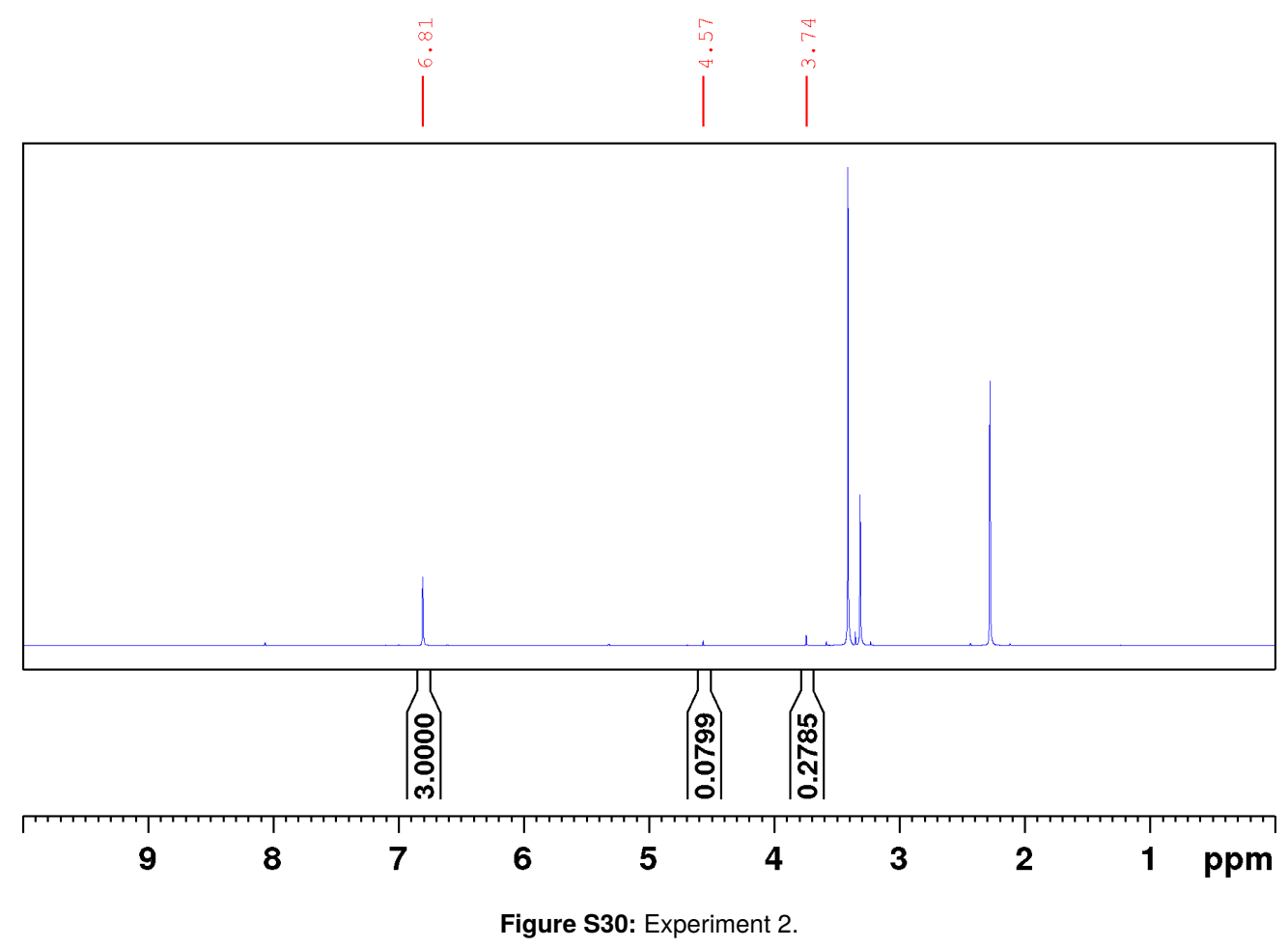




\section{Additive Loading: $1.5625 \mu \mathrm{mol}$}

$$
\begin{aligned}
T & =90^{\circ} \mathrm{C} & n_{\text {cat }} & =0.375 \mu \mathrm{mol} \\
p_{\mathrm{H} 2} & =90 \mathrm{bar} & n_{\text {add }} & =1.5625 \mu \mathrm{mol} \\
p_{\mathrm{CO} 2} & =20 \mathrm{bar} & \text { add } & =\mathrm{Al}(\mathrm{OTf})_{3} \\
t & =18 \mathrm{~h} & V_{\mathrm{MeOH}} & =0.5 \mathrm{~mL}
\end{aligned}
$$

Table S14: Catalyses results of catalyst $\left[\mathrm{Ru}\left({ }^{\mathrm{Ph}} \mathrm{Si}\right.\right.$-triphos $\left.\left.{ }^{\mathrm{Ph}}\right)(\mathrm{tmm})\right]$ 2a at an additive loading of $1.5625 \mu \mathrm{mol}$.

\begin{tabular}{lccccc}
\hline & Integral $_{\mathrm{DMM}}$ & TON $_{\mathrm{DMM}}$ & Integral $_{\mathrm{MF}}$ & TON $_{\mathrm{MF}}$ & Ratio \\
\hline Experiment 1 & 0.1300 & 436 & 0.2540 & 568 & 0.77 \\
Experiment 2 & 0.1305 & 438 & 0.2524 & 564 & 0.78 \\
Average & - & $437(1)$ & - & $566(3)$ & $0.77(0.01)$ \\
\hline
\end{tabular}

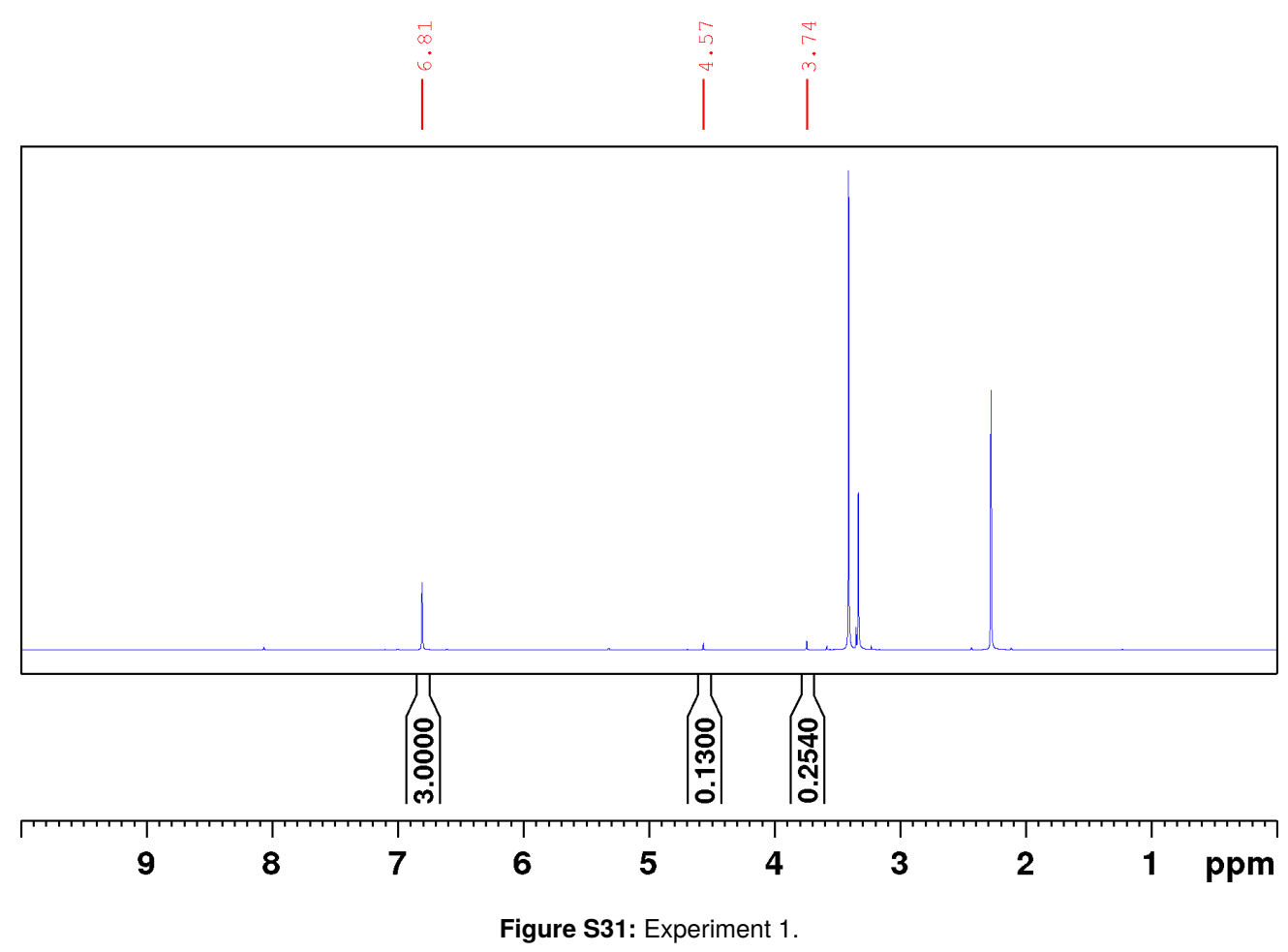




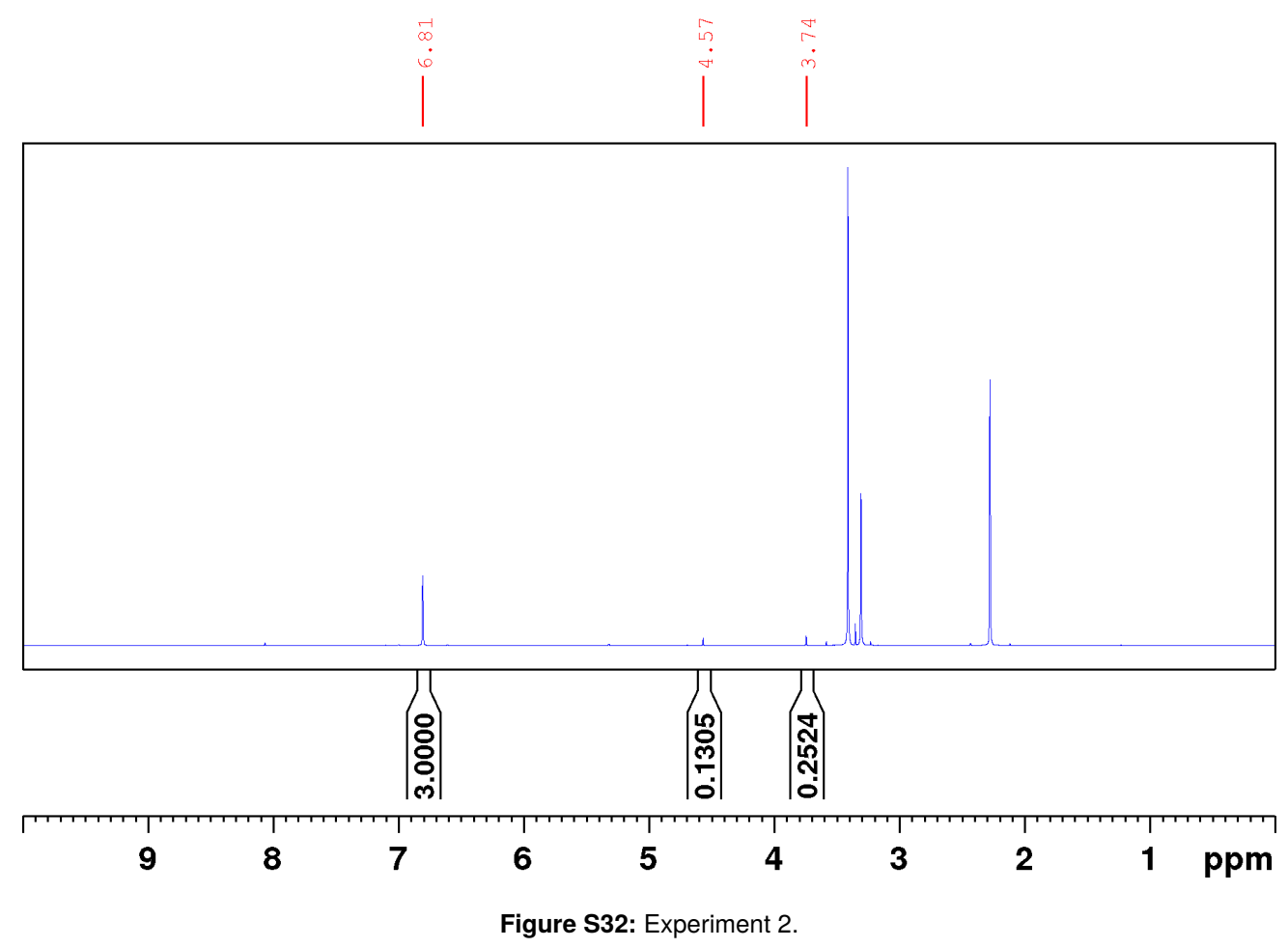




\section{Additive Loading: $3.125 \mu \mathrm{mol}$}

$$
\begin{aligned}
T & =90^{\circ} \mathrm{C} & n_{\text {cat }} & =0.375 \mu \mathrm{mol} \\
p_{\mathrm{H} 2} & =90 \mathrm{bar} & n_{\mathrm{add}} & =3.125 \mu \mathrm{mol} \\
p_{\mathrm{CO} 2} & =20 \mathrm{bar} & \text { add } & =\mathrm{Al}(\mathrm{OTf})_{3} \\
t & =18 \mathrm{~h} & V_{\mathrm{MeOH}} & =0.5 \mathrm{~mL}
\end{aligned}
$$

Table S15: Catalyses results of catalyst $\left[\mathrm{Ru}\left({ }^{\mathrm{Ph}}{ }^{\mathrm{Si}}\right.\right.$-triphos $\left.\left.{ }^{\mathrm{Ph}}\right)(\mathrm{tmm})\right]$ 2a at an additive loading of $3.125 \mu \mathrm{mol}$.

\begin{tabular}{lccccc}
\hline & Integral $_{\mathrm{DMM}}$ & $\mathrm{TON}_{\mathrm{DMM}}$ & Integral $_{\mathrm{MF}}$ & $\mathrm{TON}_{\mathrm{MF}}$ & Ratio \\
\hline Experiment 1 & 0.2064 & 692 & 0.2020 & 452 & 1.53 \\
Experiment 2 & 0.1977 & 663 & 0.2017 & 451 & 1.47 \\
Average & - & $678(21)$ & - & $452(1)$ & $1.50(0.04)$ \\
\hline
\end{tabular}

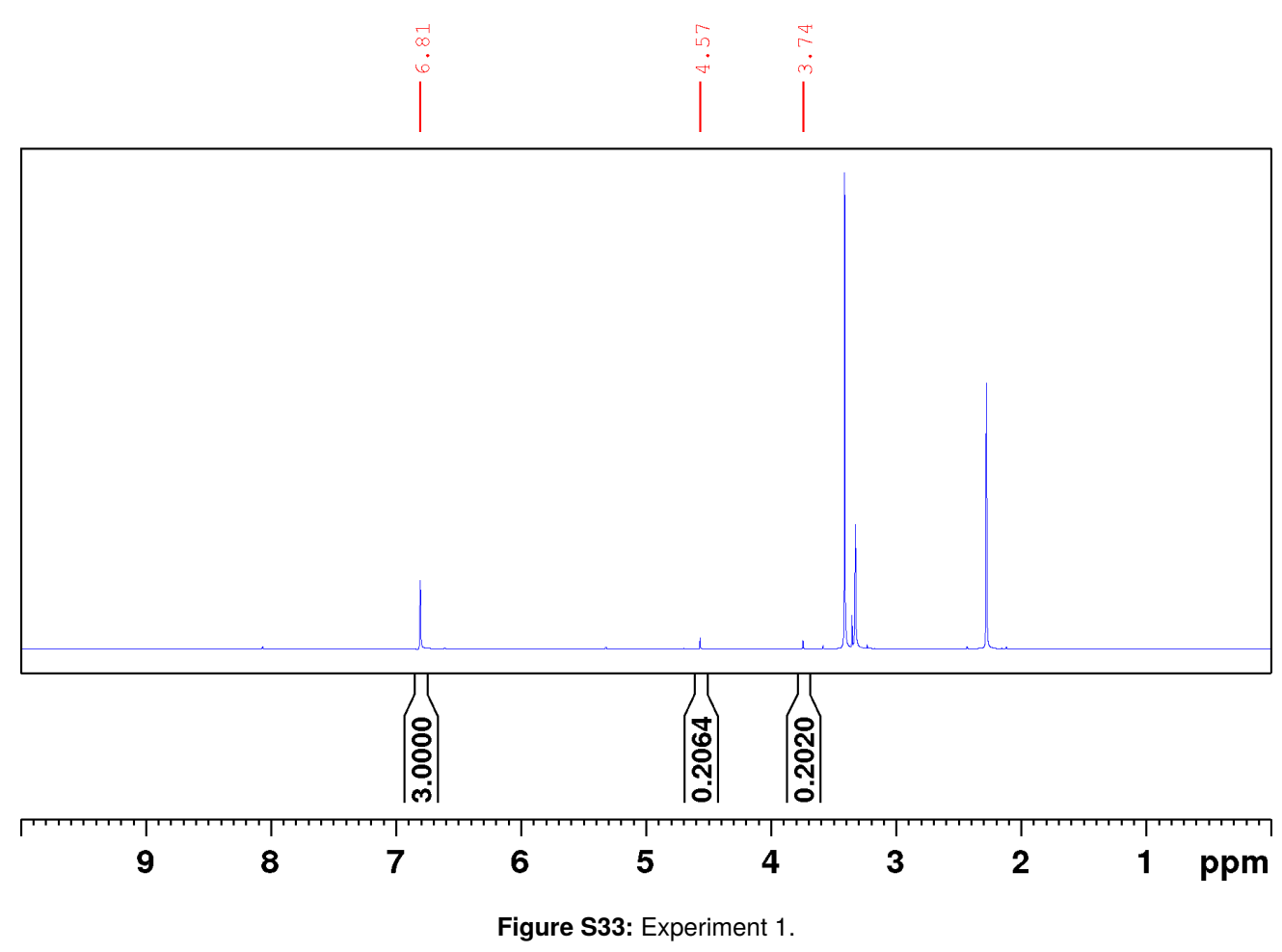




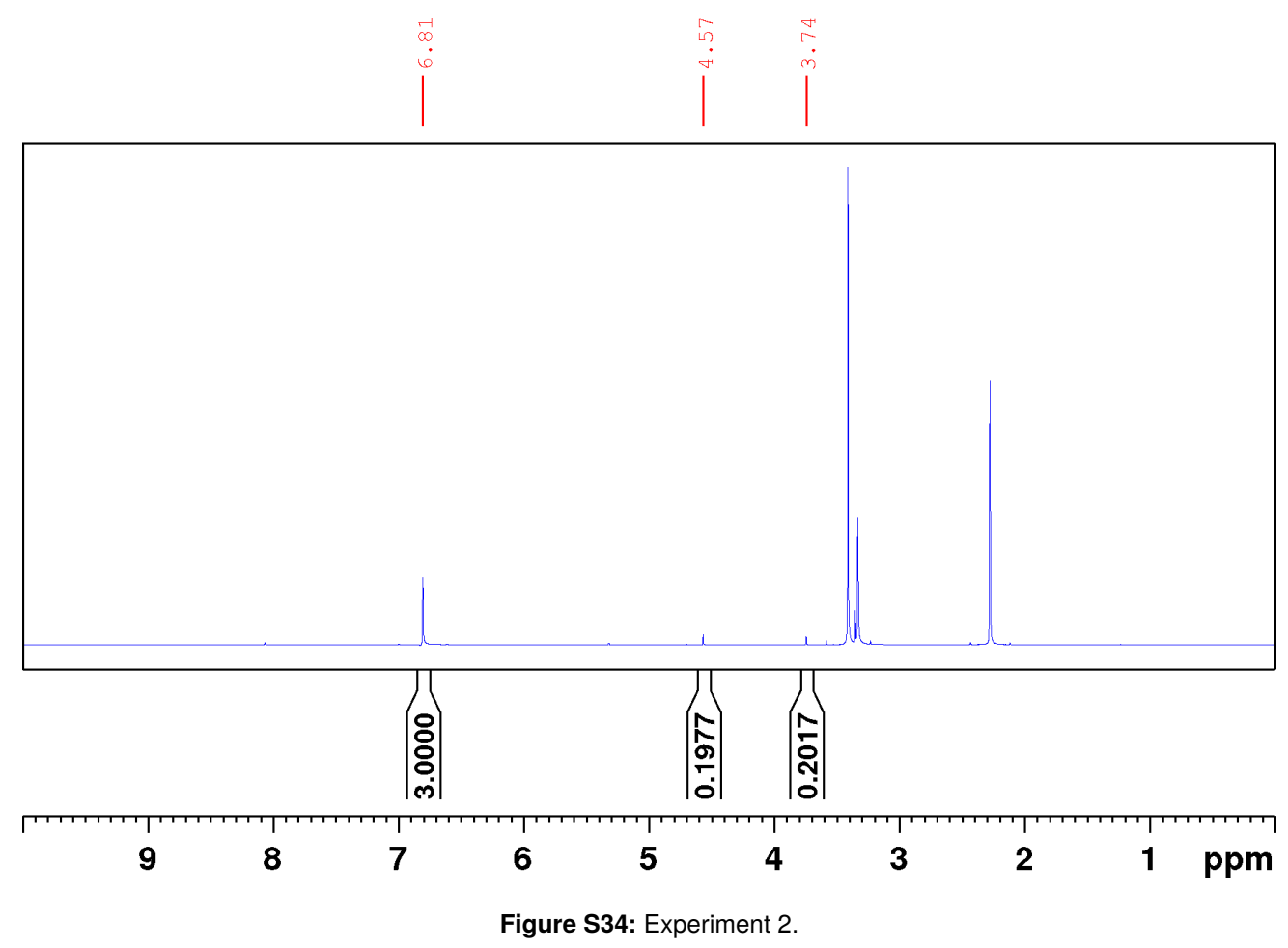




\subsection{2 $\left[\mathrm{Ru}\left({ }^{\mathrm{Me}} \mathrm{Si}\right.\right.$-triphos $\left.\left.{ }^{\mathrm{Ph}}\right)(\mathrm{tmm})\right] 2 \mathrm{~b}$}

Temperature: $80^{\circ} \mathrm{C}$

$$
\begin{aligned}
\mathrm{T} & =80^{\circ} \mathrm{C} & n_{\mathrm{cat}} & =0.375 \mu \mathrm{mol} \\
p_{\mathrm{H} 2} & =90 \mathrm{bar} & n_{\mathrm{add}} & =1.5625 \mu \mathrm{mol} \\
p_{\mathrm{CO} 2} & =20 \mathrm{bar} & \text { add } & =\mathrm{Al}(\mathrm{OTf})_{3} \\
t & =18 \mathrm{~h} & V_{\mathrm{MeOH}} & =0.5 \mathrm{~mL}
\end{aligned}
$$

Table S16: Catalyses results of catalyst $\left[\mathrm{Ru}\left({ }^{\mathrm{Me}} \mathrm{Si}\right.\right.$-triphos $\left.\left.{ }^{\mathrm{Ph}}\right)(\mathrm{tmm})\right] \mathbf{2 b}$ at $80^{\circ} \mathrm{C}$.

\begin{tabular}{lccccc}
\hline & Integral $_{\mathrm{DMM}}$ & $\mathrm{TON}_{\mathrm{DMM}}$ & Integral $_{\mathrm{MF}}$ & $\mathrm{TON}_{\mathrm{MF}}$ & Ratio \\
\hline Experiment 1 & 0.0940 & 315 & 0.3488 & 780 & 0.40 \\
Experiment 2 & 0.1238 & 415 & 0.3172 & 709 & 0.59 \\
Average & - & $365(71)$ & - & $747(50)$ & $0.49(0.13)$ \\
\hline
\end{tabular}

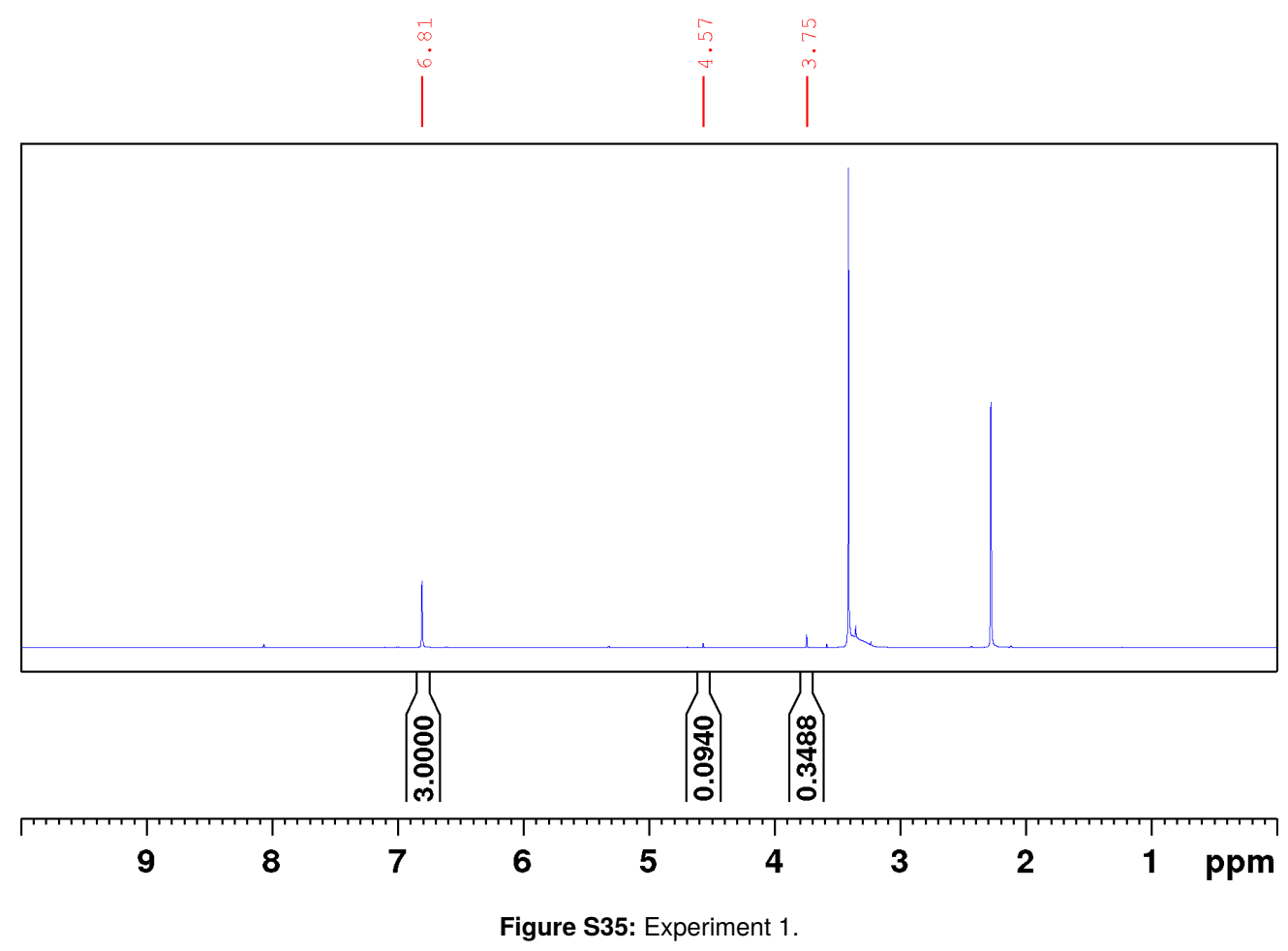




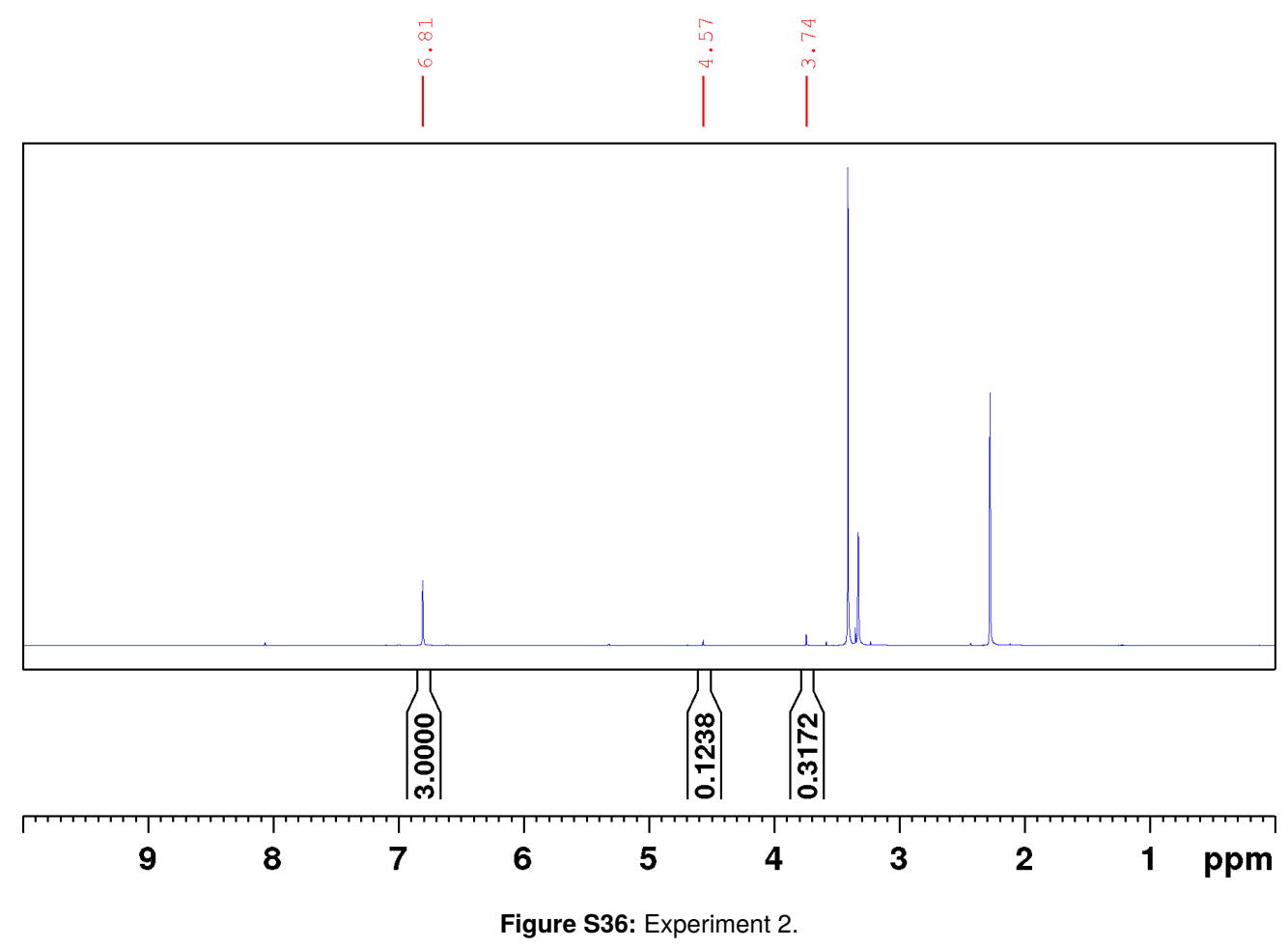




\section{Temperature: $90^{\circ} \mathrm{C}$}

$$
\begin{array}{rlrl}
\mathrm{T} & =90^{\circ} \mathrm{C} & n_{\text {cat }} & =0.375 \mu \mathrm{mol} \\
p_{\mathrm{H} 2} & =90 \mathrm{bar} & n_{\text {add }} & =1.5625 \mu \mathrm{mol} \\
p_{\mathrm{CO} 2} & =20 \mathrm{bar} & \mathrm{add} & =\mathrm{Al}(\mathrm{OTf})_{3} \\
t & =18 \mathrm{~h} & V_{\mathrm{MeOH}} & =0.5 \mathrm{~mL}
\end{array}
$$

Table S17: Catalyses results of catalyst $\left[\mathrm{Ru}\left({ }^{\mathrm{Me}} \mathrm{Si}\right.\right.$-triphos $\left.\left.{ }^{\mathrm{Ph}}\right)(\mathrm{tmm})\right] \mathbf{2 b}$ at $90^{\circ} \mathrm{C}$.

\begin{tabular}{lccccc}
\hline & Integral $_{\mathrm{DMM}}$ & $\mathrm{TON}_{\mathrm{DMM}}$ & Integral $_{\mathrm{MF}}$ & $\mathrm{TON}_{\mathrm{MF}}$ & Ratio \\
\hline Experiment 1 & 0.1438 & 482 & 0.2831 & 633 & 0.76 \\
Experiment 2 & 0.1591 & 534 & 0.2699 & 604 & 0.88 \\
Average & - & $508(37)$ & - & $619(21)$ & $0.82(0.09)$ \\
\hline
\end{tabular}

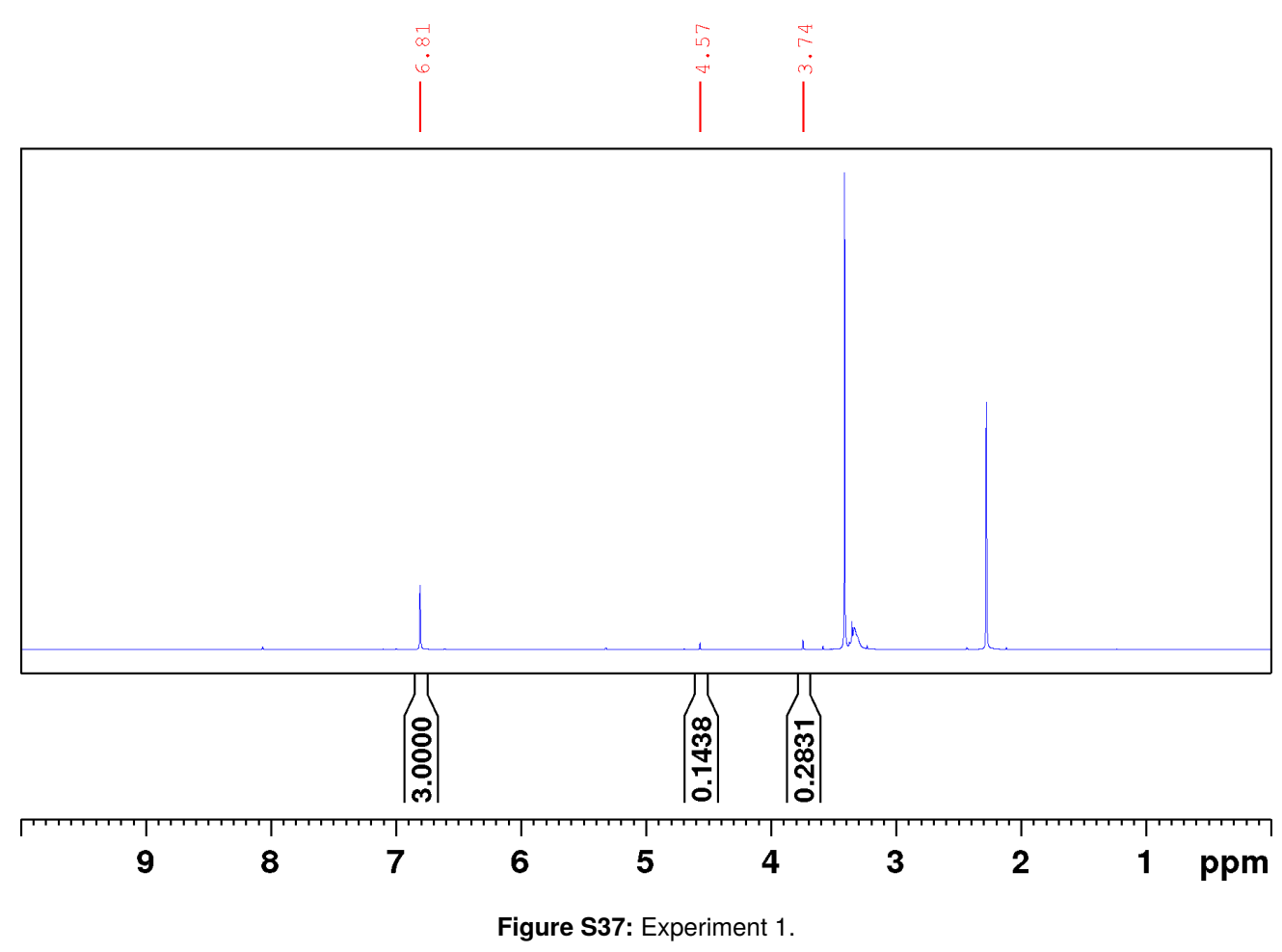




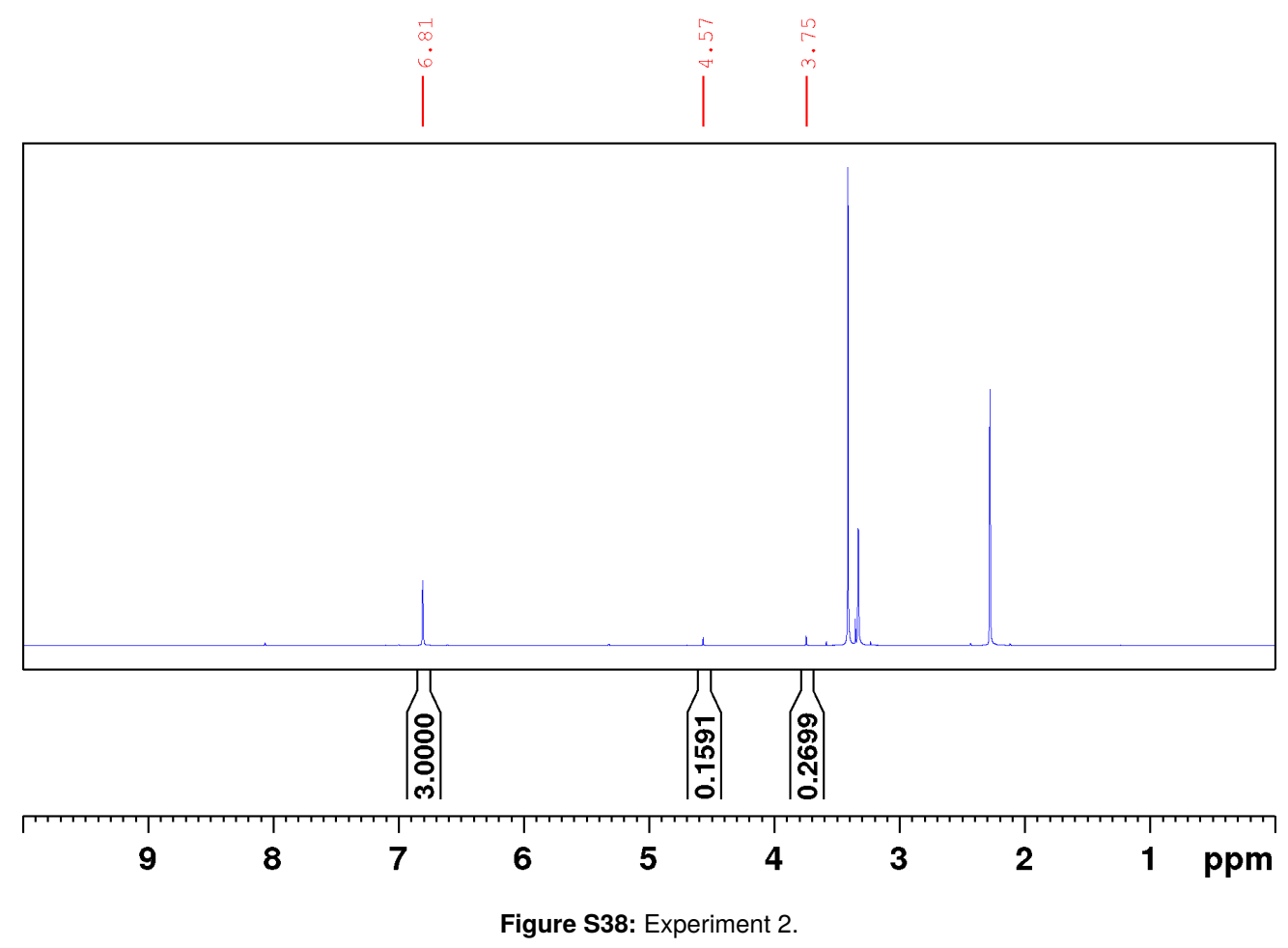


Temperature: $100^{\circ} \mathrm{C}$

$$
\begin{aligned}
T & =100{ }^{\circ} \mathrm{C} & n_{\text {cat }} & =0.375 \mu \mathrm{mol} \\
p_{\mathrm{H} 2} & =90 \mathrm{bar} & n_{\mathrm{add}} & =1.5625 \mu \mathrm{mol} \\
p_{\mathrm{CO} 2} & =20 \mathrm{bar} & \text { add } & =\mathrm{Al}(\mathrm{OTf})_{3} \\
t & =18 \mathrm{~h} & V_{\mathrm{MeOH}} & =0.5 \mathrm{~mL}
\end{aligned}
$$

Table S18: Catalyses results of catalyst $\left[\mathrm{Ru}\left({ }^{\mathrm{Me}} \mathrm{Si}\right.\right.$-triphos $\left.\left.{ }^{\mathrm{Ph}}\right)(\mathrm{tmm})\right] \mathbf{2 b}$ at $100^{\circ} \mathrm{C}$.

\begin{tabular}{lccccc}
\hline & Integral $_{\mathrm{DMM}}$ & $\mathrm{TON}_{\mathrm{DMM}}$ & Integral $_{\mathrm{MF}}$ & $\mathrm{TON}_{\mathrm{MF}}$ & Ratio \\
\hline Experiment 1 & 0.1312 & 440 & 0.2144 & 479 & 0.92 \\
Experiment 2 & 0.1170 & 392 & 0.1615 & 361 & 1.09 \\
Average & - & $416(34)$ & - & $420(84)$ & $1.00(0.12)$ \\
\hline
\end{tabular}

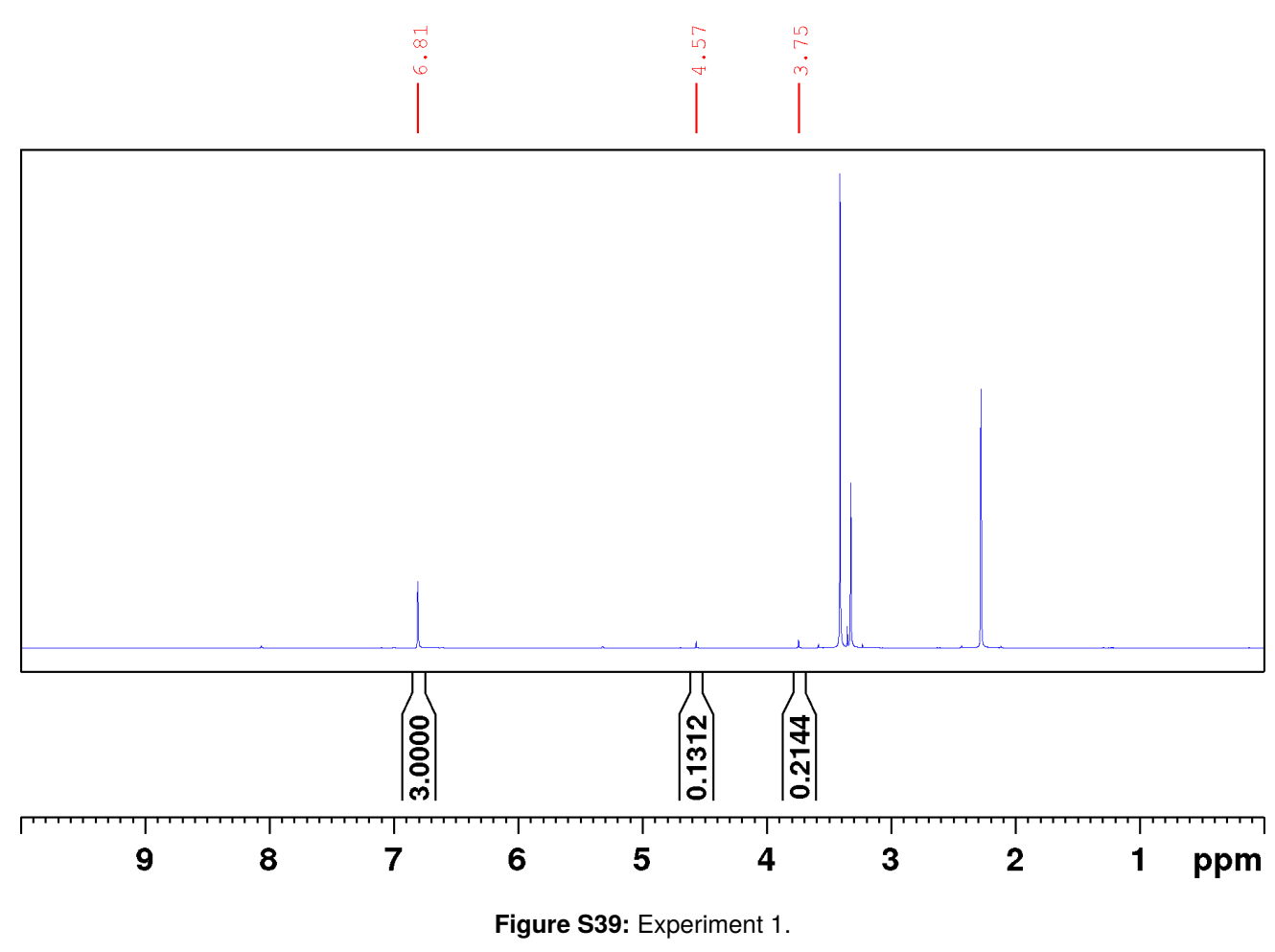




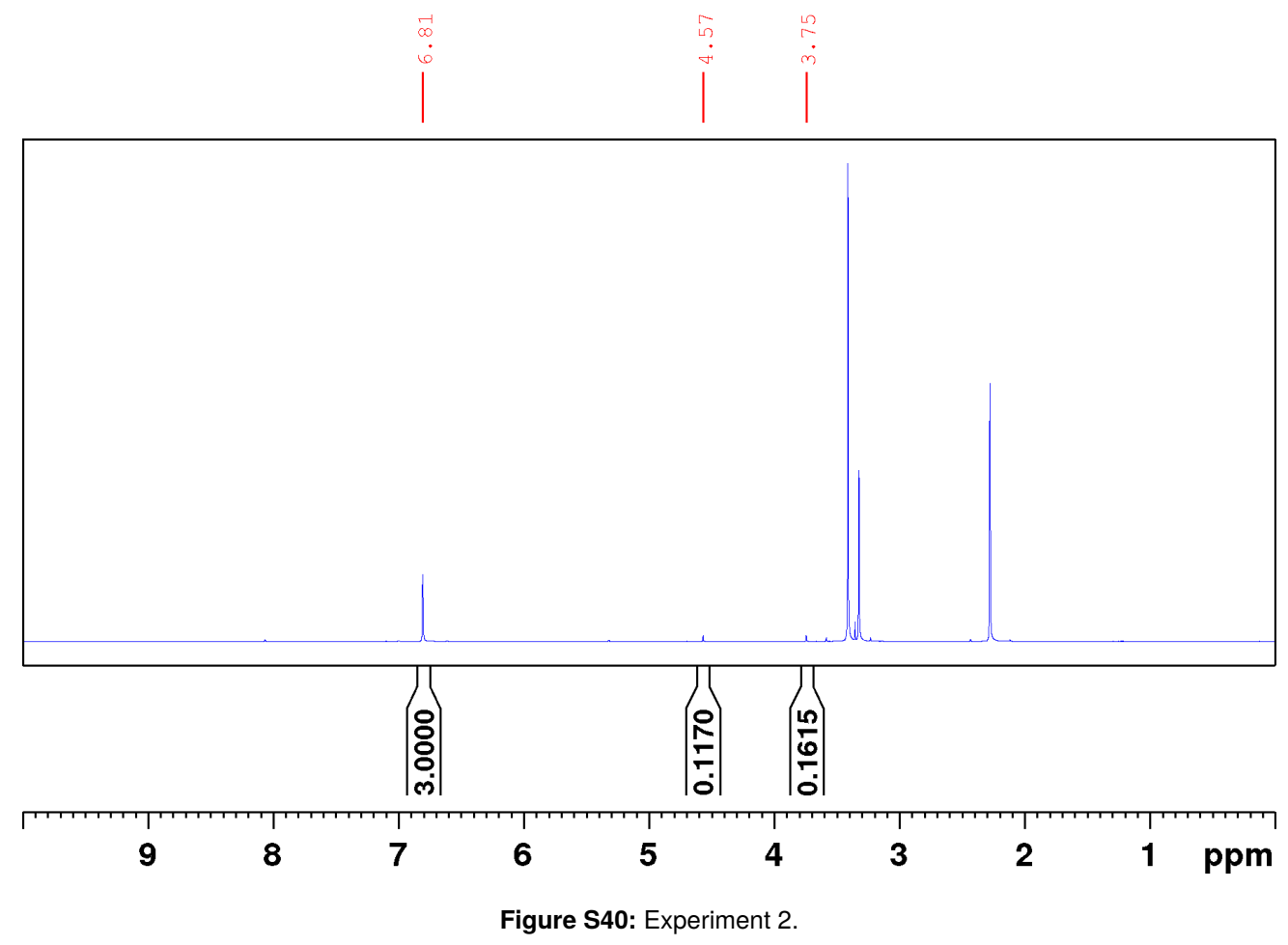




\section{$\mathrm{H}_{2}$ Pressure: 80 bar}

$$
\begin{aligned}
T & =90^{\circ} \mathrm{C} & n_{\text {cat }} & =0.375 \mu \mathrm{mol} \\
p_{\mathrm{H} 2} & =80 \mathrm{bar} & n_{\text {add }} & =1.5625 \mu \mathrm{mol} \\
p_{\mathrm{CO} 2} & =20 \mathrm{bar} & \text { add } & =\mathrm{Al}(\mathrm{OTf})_{3} \\
t & =18 \mathrm{~h} & V_{\mathrm{MeOH}} & =0.5 \mathrm{~mL}
\end{aligned}
$$

Table S19: Catalyses results of catalyst $\left[\mathrm{Ru}\left({ }^{\mathrm{Me}} \mathrm{Si}\right.\right.$-triphos $\left.\left.{ }^{\mathrm{Ph}}\right)(\mathrm{tmm})\right] \mathbf{2} \mathbf{b}$ at 80 bar $\mathrm{H}_{2}$ pressure.

\begin{tabular}{lccccc}
\hline & Integral $_{\mathrm{DMM}}$ & $\mathrm{TON}_{\mathrm{DMM}}$ & Integral $_{\mathrm{MF}}$ & $\mathrm{TON}_{\mathrm{MF}}$ & Ratio \\
\hline Experiment 1 & 0.1387 & 465 & 0.2648 & 592 & 0.79 \\
Experiment 2 & 0.1330 & 446 & 0.2800 & 626 & 0.71 \\
Average & - & $456(13)$ & - & $609(24)$ & $0.75(0.05)$ \\
\hline
\end{tabular}

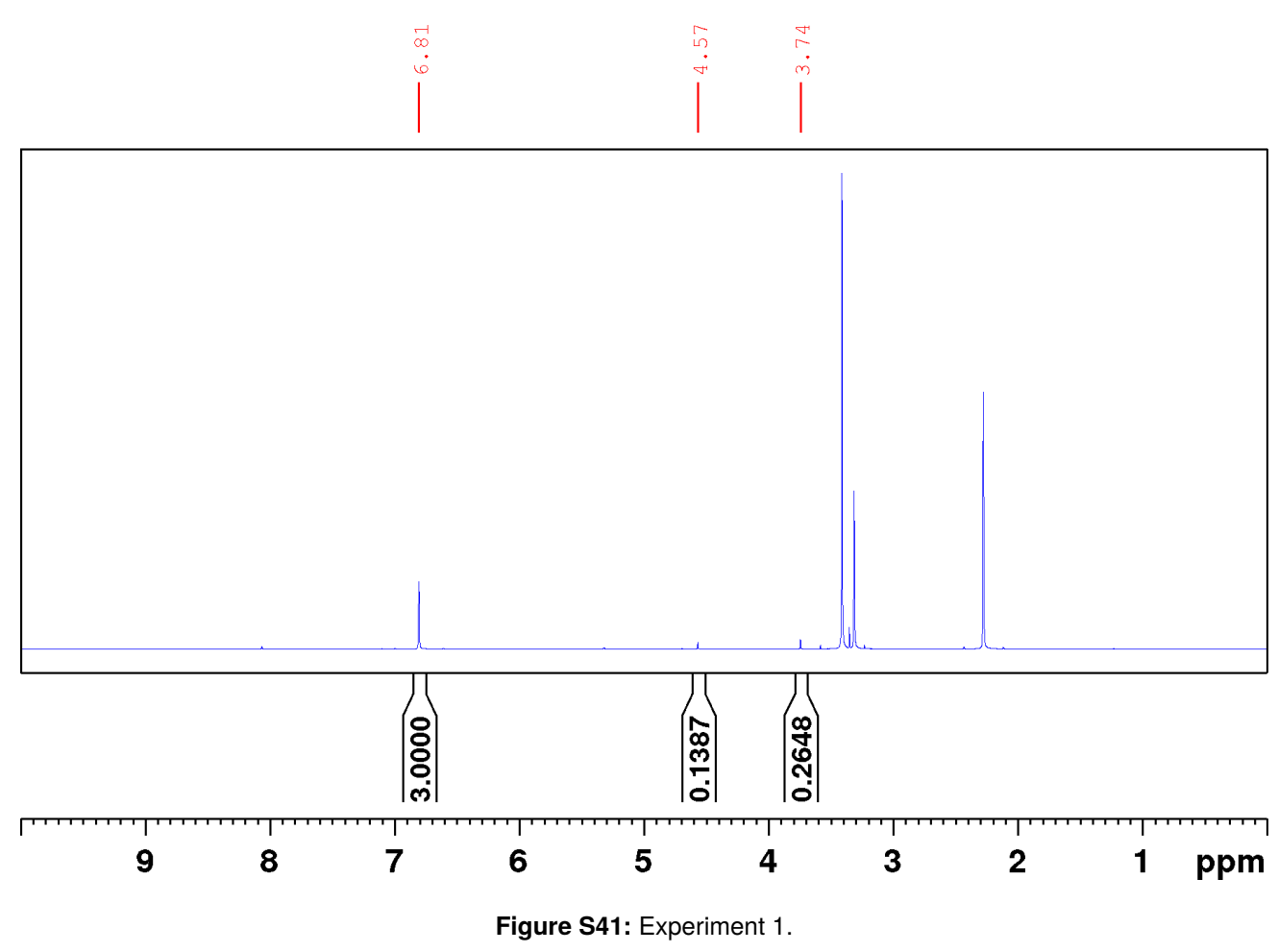




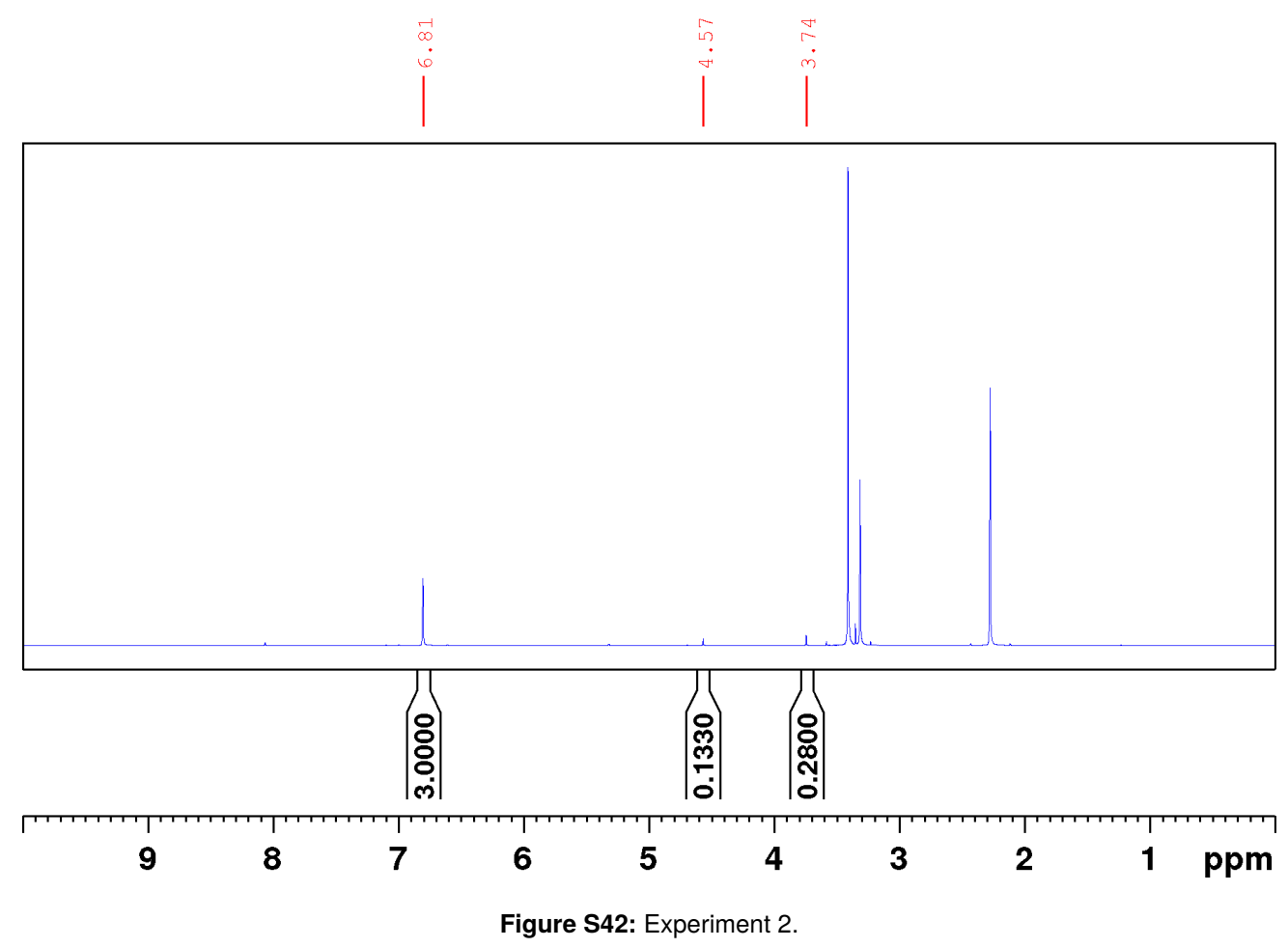




\section{$\mathrm{H}_{2}$ Pressure: $90 \mathrm{bar}$}

$$
\begin{aligned}
T & =90^{\circ} \mathrm{C} & n_{\text {cat }} & =0.375 \mu \mathrm{mol} \\
p_{\mathrm{H} 2} & =90 \mathrm{bar} & n_{\text {add }} & =1.5625 \mu \mathrm{mol} \\
p_{\mathrm{CO} 2} & =20 \mathrm{bar} & \text { add } & =\mathrm{Al}(\mathrm{OTf})_{3} \\
t & =18 \mathrm{~h} & V_{\mathrm{MeOH}} & =0.5 \mathrm{~mL}
\end{aligned}
$$

Table S20: Catalyses results of catalyst $\left[\mathrm{Ru}\left({ }^{\mathrm{Me}} \mathrm{Si}\right.\right.$-triphos $\left.\left.{ }^{\mathrm{Ph}}\right)(\mathrm{tmm})\right] \mathbf{2} \mathbf{b}$ at 90 bar $\mathrm{H}_{2}$ pressure.

\begin{tabular}{lccccc}
\hline & Integral $_{\mathrm{DMM}}$ & $\mathrm{TON}_{\mathrm{DMM}}$ & Integral $_{\mathrm{MF}}$ & $\mathrm{TON}_{\mathrm{MF}}$ & Ratio \\
\hline Experiment 1 & 0.1438 & 482 & 0.2831 & 633 & 0.76 \\
Experiment 2 & 0.1591 & 534 & 0.2699 & 604 & 0.88 \\
Average & - & $508(37)$ & - & $619(21)$ & $0.82(0.09)$ \\
\hline
\end{tabular}

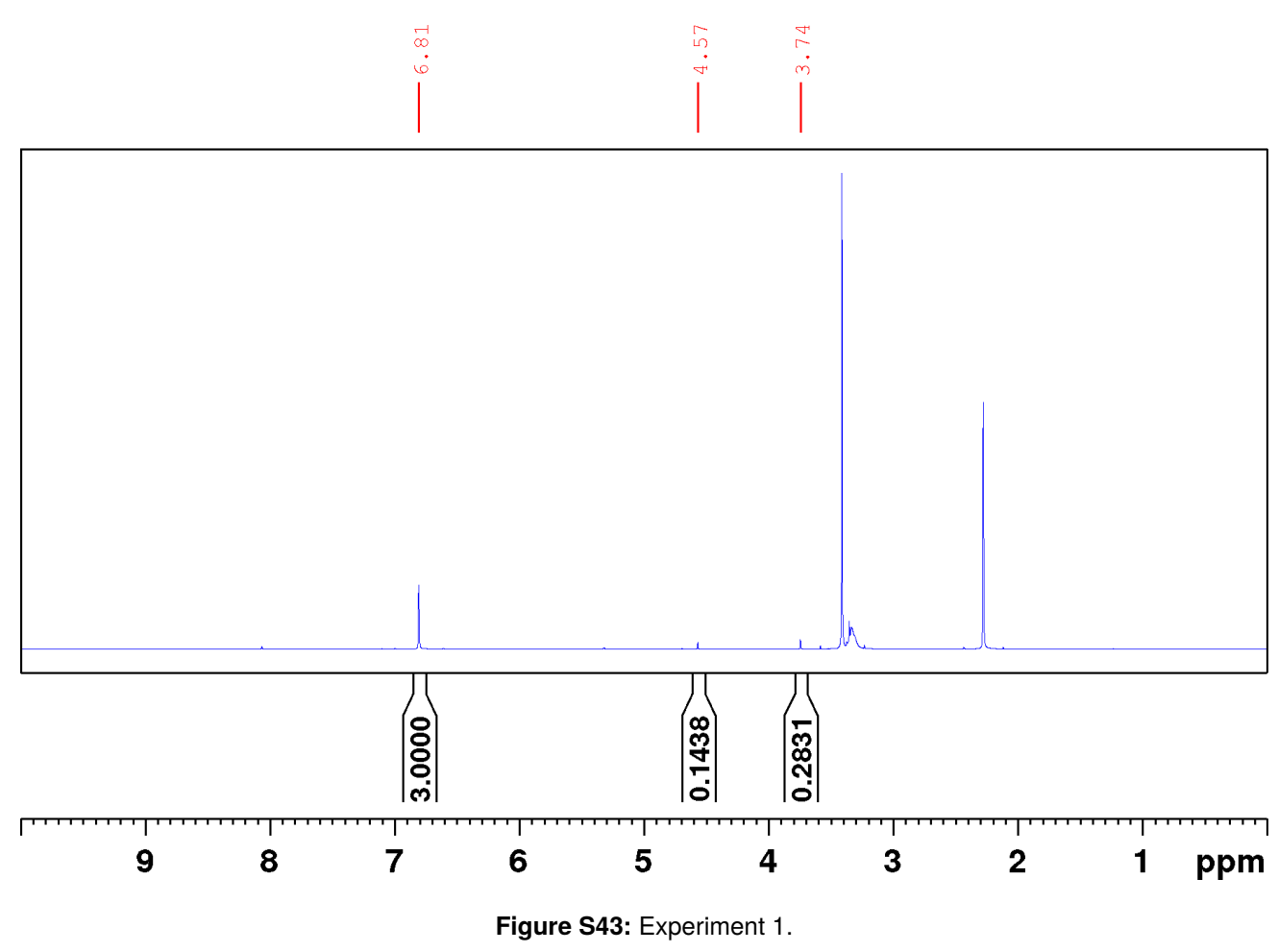




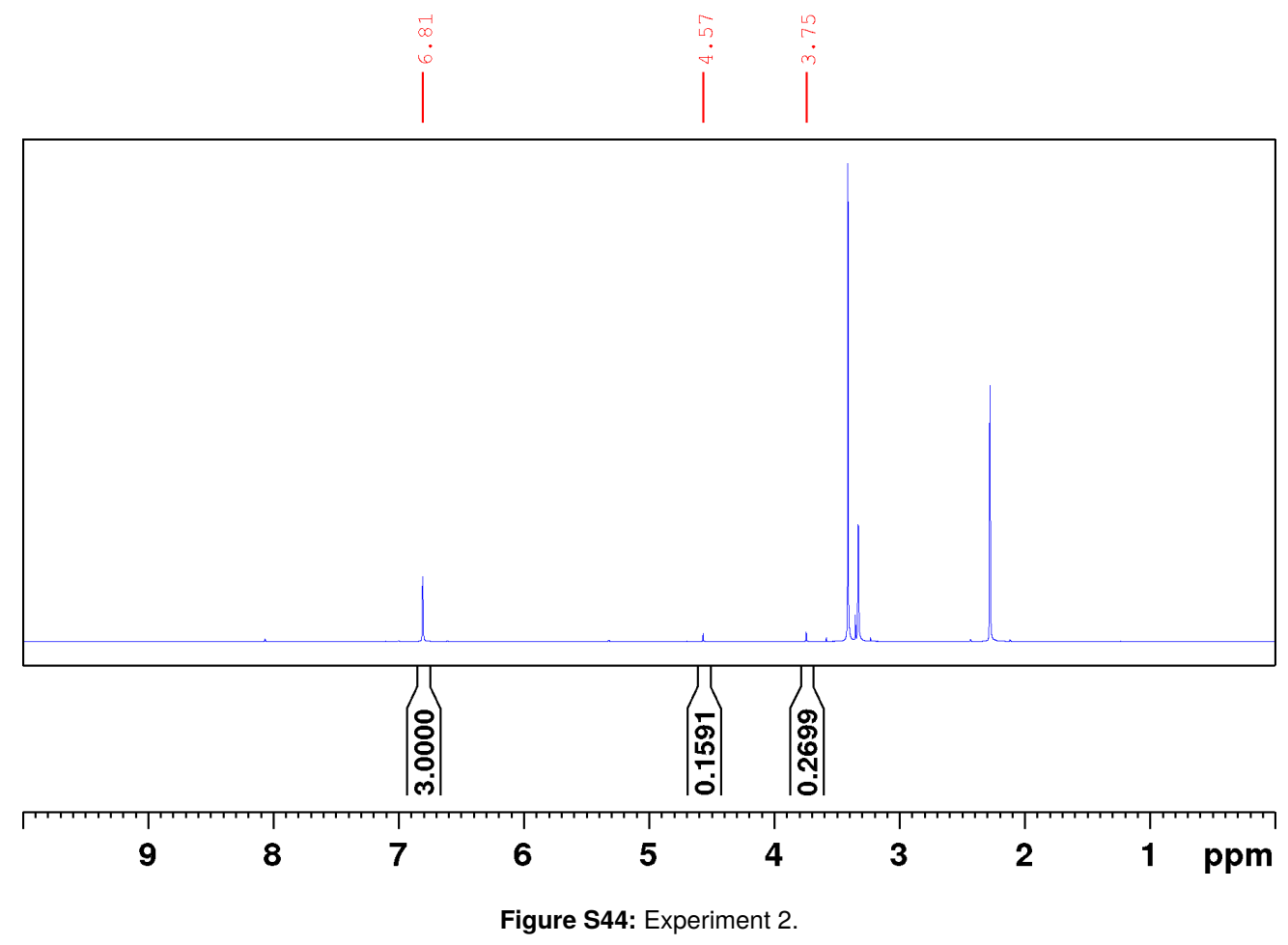


$H_{2}$ Pressure: 100 bar

$$
\begin{aligned}
T & =90^{\circ} \mathrm{C} & n_{\text {cat }} & =0.375 \mu \mathrm{mol} \\
p_{\mathrm{H} 2} & =100 \mathrm{bar} & n_{\text {add }} & =1.5625 \mu \mathrm{mol} \\
p_{\mathrm{CO} 2} & =20 \mathrm{bar} & \text { add } & =\mathrm{Al}(\mathrm{OTf})_{3} \\
t & =18 \mathrm{~h} & V_{\mathrm{MeOH}} & =0.5 \mathrm{~mL}
\end{aligned}
$$

Table S21: Catalyses results of catalyst $\left[\mathrm{Ru}\left({ }^{\mathrm{Me}} \mathrm{Si}\right.\right.$-triphos $\left.\left.{ }^{\mathrm{Ph}}\right)(\mathrm{tmm})\right] \mathbf{2 b}$ at 100 bar $\mathrm{H}_{2}$ pressure.

\begin{tabular}{lccccc}
\hline & Integral $_{\mathrm{DMM}}$ & TON $_{\mathrm{DMM}}$ & Integral $_{\mathrm{MF}}$ & TON $_{\mathrm{MF}}$ & Ratio \\
\hline Experiment 1 & 0.1350 & 453 & 0.2923 & 654 & 0.69 \\
Experiment 2 & 0.1207 & 405 & 0.2489 & 557 & 0.73 \\
Average & - & $429(34)$ & - & $605(69)$ & $0.71(0.02)$ \\
\hline
\end{tabular}

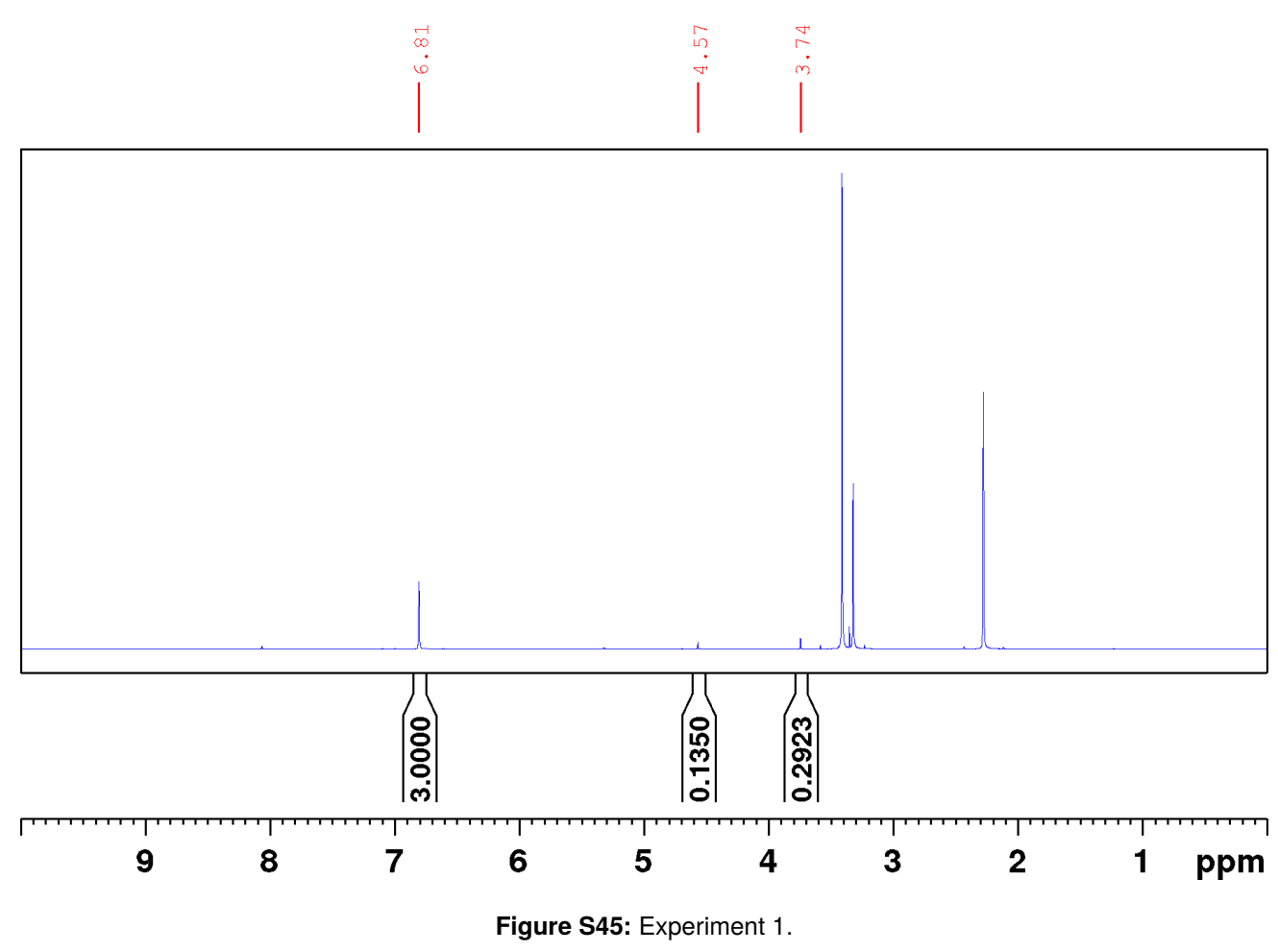




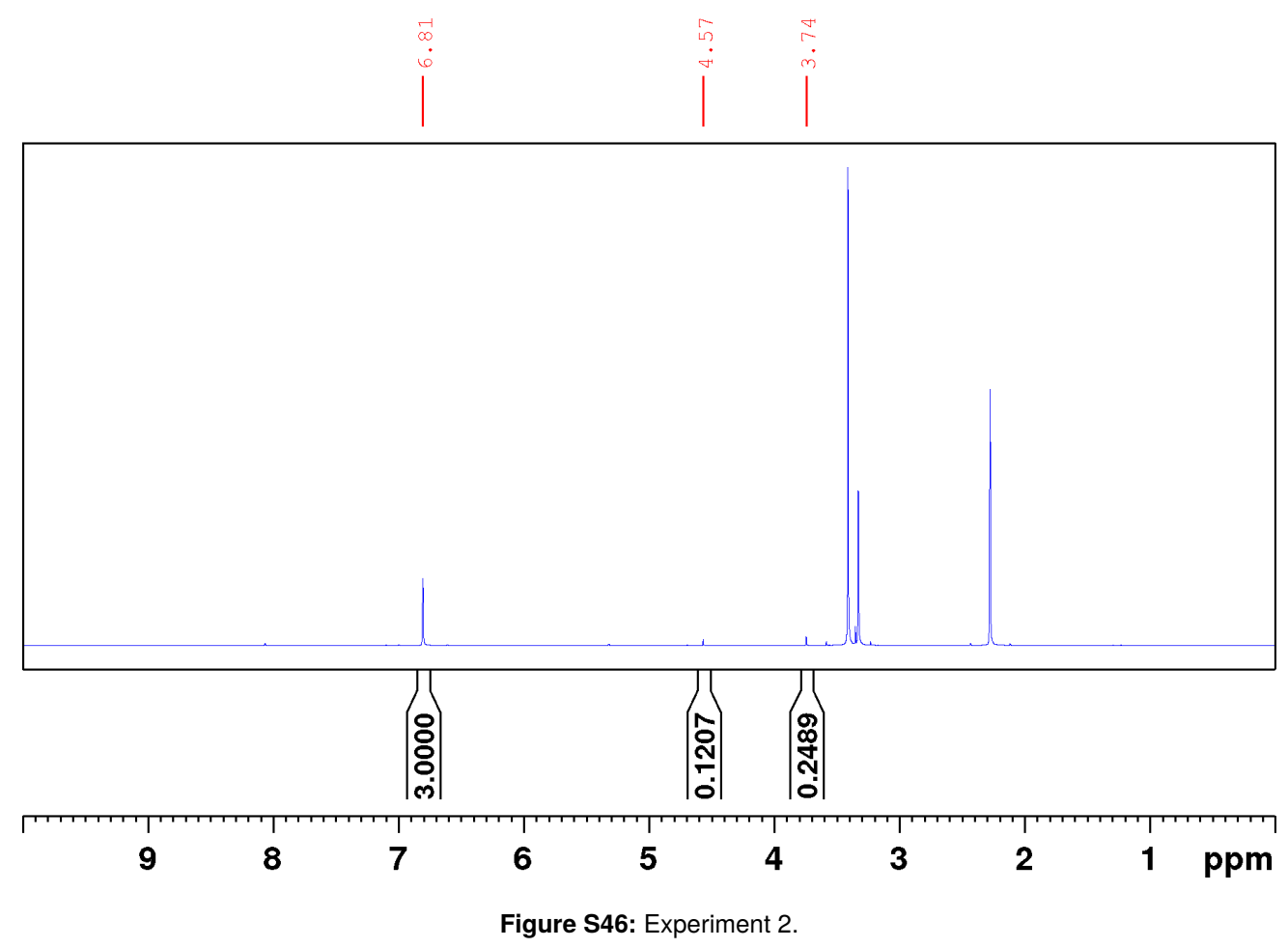


$\mathrm{CO}_{2}$ Pressure: $10 \mathrm{bar}$

$$
\begin{array}{rlrl}
T & =90^{\circ} \mathrm{C} & n_{\text {cat }} & =0.375 \mu \mathrm{mol} \\
p_{\mathrm{H} 2} & =90 \mathrm{bar} & n_{\text {add }} & =1.5625 \mu \mathrm{mol} \\
p_{\mathrm{CO} 2} & =10 \mathrm{bar} & \mathrm{add} & =\mathrm{Al}(\mathrm{OTf})_{3} \\
t & =18 \mathrm{~h} & V_{\mathrm{MeOH}} & =0.5 \mathrm{~mL}
\end{array}
$$

Table S22: Catalyses results of catalyst $\left[\mathrm{Ru}\left({ }^{\mathrm{Me}} \mathrm{Si}\right.\right.$-triphos $\left.\left.{ }^{\mathrm{Ph}}\right)(\mathrm{tmm})\right] \mathbf{2 b}$ at 10 bar $\mathrm{CO}_{2}$ pressure.

\begin{tabular}{lccccc}
\hline & Integral $_{\mathrm{DMM}}$ & $\mathrm{TON}_{\mathrm{DMM}}$ & Integral $_{\mathrm{MF}}$ & $\mathrm{TON}_{\mathrm{MF}}$ & Ratio \\
\hline Experiment 1 & 0.1230 & 413 & 0.1064 & 238 & 1.73 \\
Experiment 2 & 0.1327 & 445 & 0.1324 & 296 & 1.50 \\
Average & - & $429(23)$ & - & $267(41)$ & $1.62(0.16)$ \\
\hline
\end{tabular}

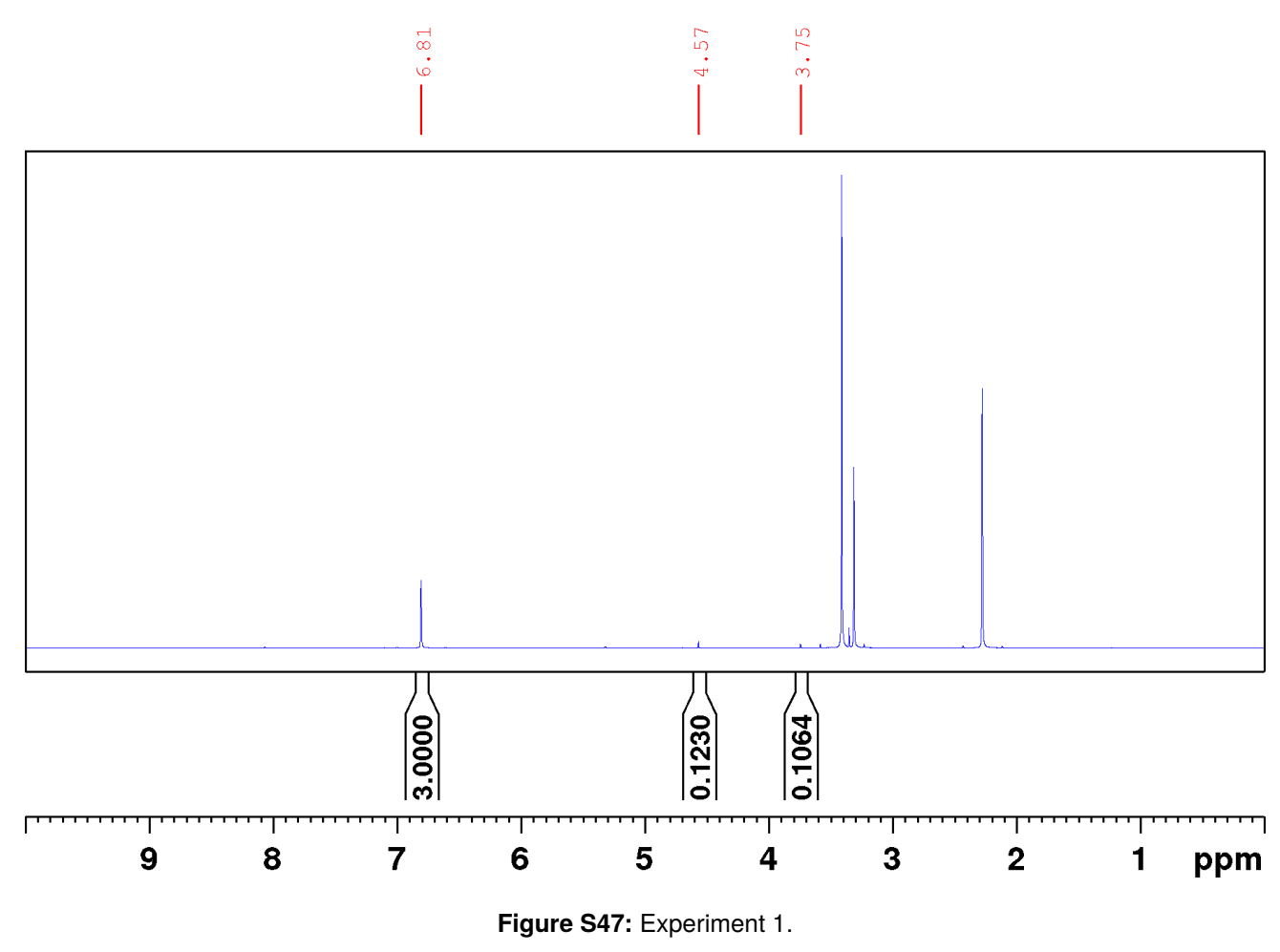




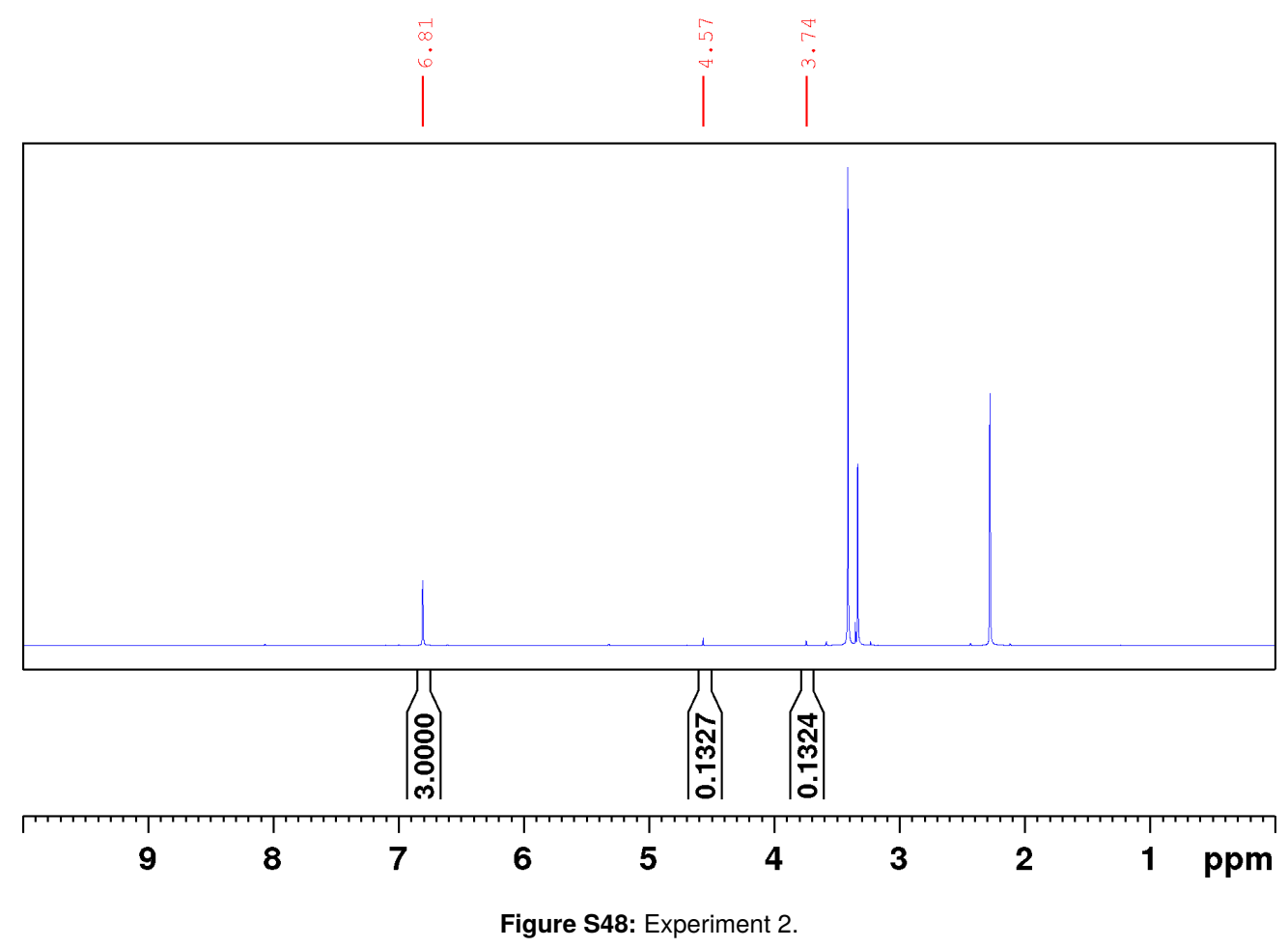




\section{$\mathrm{CO}_{2}$ Pressure: 20 bar}

$$
\begin{aligned}
T & =90^{\circ} \mathrm{C} & n_{\text {cat }} & =0.375 \mu \mathrm{mol} \\
p_{\mathrm{H} 2} & =90 \mathrm{bar} & n_{\text {add }} & =1.5625 \mu \mathrm{mol} \\
p_{\mathrm{CO} 2} & =20 \mathrm{bar} & \text { add } & =\mathrm{Al}(\mathrm{OTf})_{3} \\
t & =18 \mathrm{~h} & V_{\mathrm{MeOH}} & =0.5 \mathrm{~mL}
\end{aligned}
$$

Table S23: Catalyses results of catalyst $\left[\mathrm{Ru}\left({ }^{\mathrm{Me}} \mathrm{Si}\right.\right.$-triphos $\left.\left.{ }^{\mathrm{Ph}}\right)(\mathrm{tmm})\right] \mathbf{2 b}$ at 20 bar $\mathrm{CO}_{2}$ pressure.

\begin{tabular}{lccccc}
\hline & Integral $_{\mathrm{DMM}}$ & TON $_{\mathrm{DMM}}$ & Integral $_{\mathrm{MF}}$ & TON $_{\mathrm{MF}}$ & Ratio \\
\hline Experiment 1 & 0.1438 & 482 & 0.2831 & 633 & 0.76 \\
Experiment 2 & 0.1591 & 534 & 0.2699 & 604 & 0.88 \\
Average & - & $508(37)$ & - & $619(21)$ & $0.82(0.09)$ \\
\hline
\end{tabular}

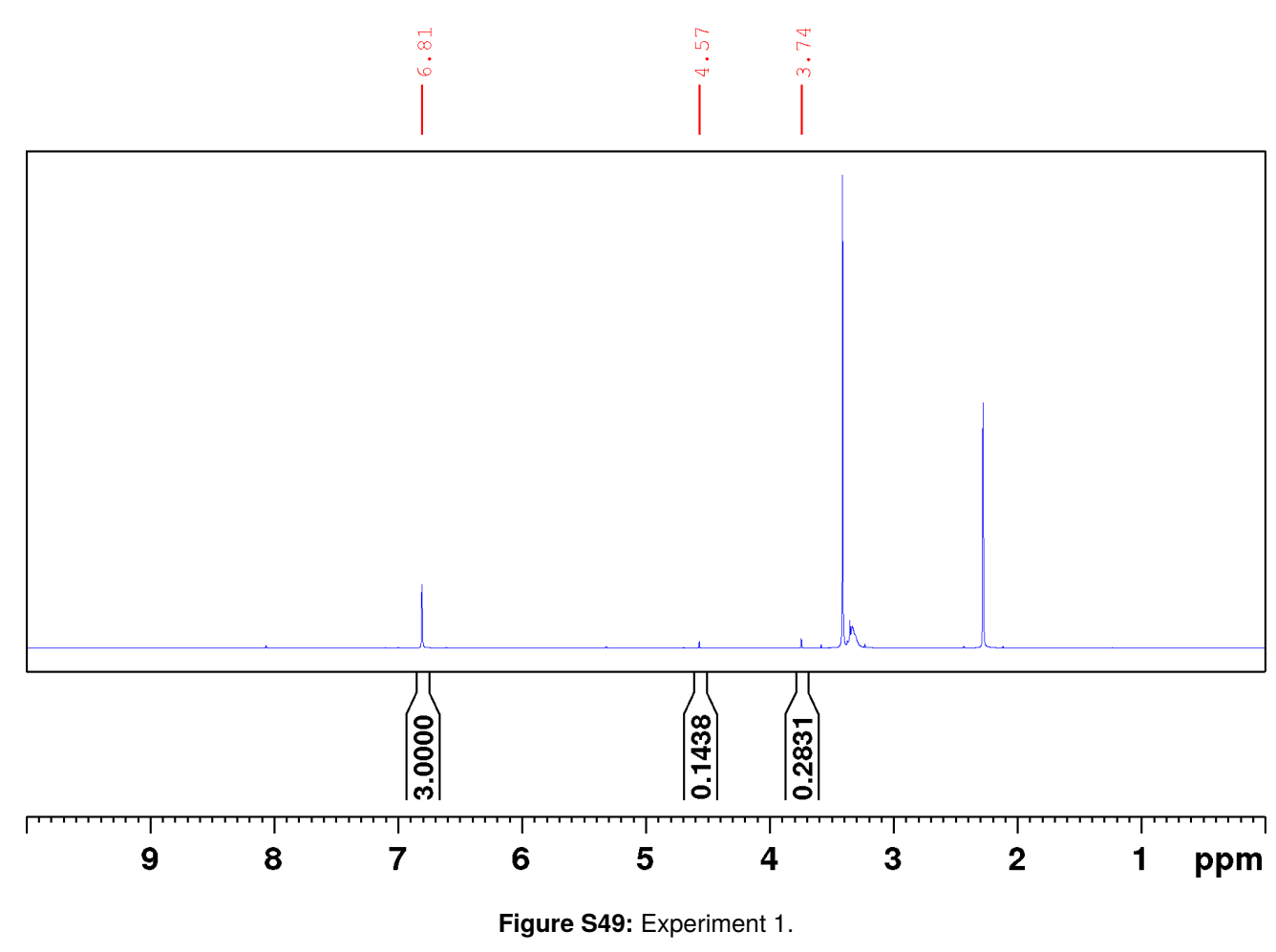




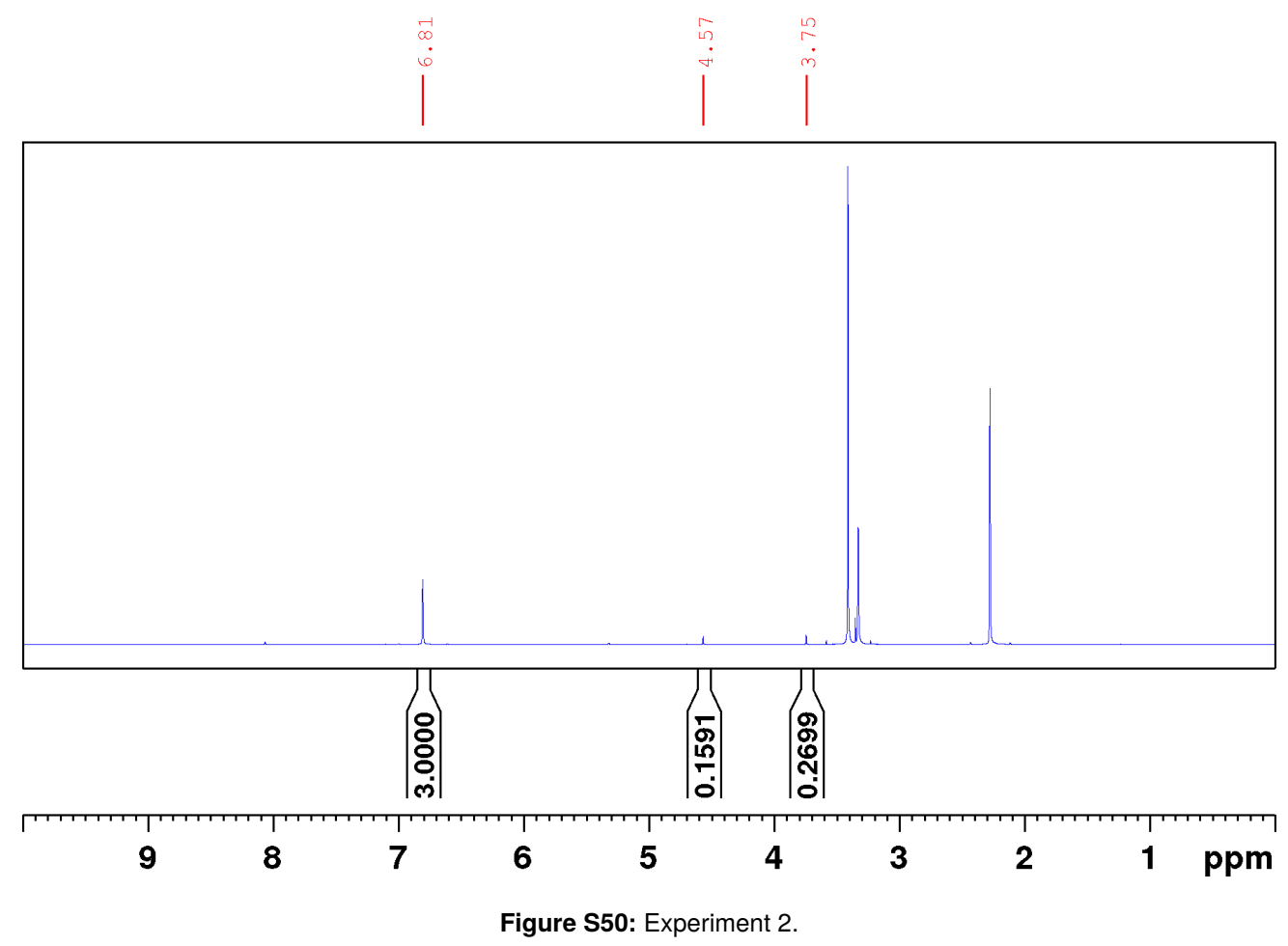




\section{$\mathrm{CO}_{2}$ Pressure: 30 bar}

$$
\begin{aligned}
T & =90^{\circ} \mathrm{C} & n_{\text {cat }} & =0.375 \mu \mathrm{mol} \\
p_{\mathrm{H} 2} & =90 \mathrm{bar} & n_{\text {add }} & =1.5625 \mu \mathrm{mol} \\
p_{\mathrm{CO} 2} & =30 \mathrm{bar} & \text { add } & =\mathrm{Al}(\mathrm{OTf})_{3} \\
t & =18 \mathrm{~h} & V_{\mathrm{MeOH}} & =0.5 \mathrm{~mL}
\end{aligned}
$$

Table S24: Catalyses results of catalyst $\left[\mathrm{Ru}\left({ }^{\mathrm{Me}} \mathrm{Si}\right.\right.$-triphos $\left.\left.{ }^{\mathrm{Ph}}\right)(\mathrm{tmm})\right] \mathbf{2 b}$ at 30 bar $\mathrm{CO}_{2}$ pressure.

\begin{tabular}{lccccc}
\hline & Integral $_{\mathrm{DMM}}$ & $\mathrm{TON}_{\mathrm{DMM}}$ & Integral $_{\mathrm{MF}}$ & $\mathrm{TON}_{\mathrm{MF}}$ & Ratio \\
\hline Experiment 1 & 0.1317 & 442 & 0.3380 & 756 & 0.58 \\
Experiment 2 & 0.1427 & 479 & 0.3188 & 713 & 0.67 \\
Average & - & $460(26)$ & - & $734(30)$ & $0.63(0.06)$ \\
\hline
\end{tabular}

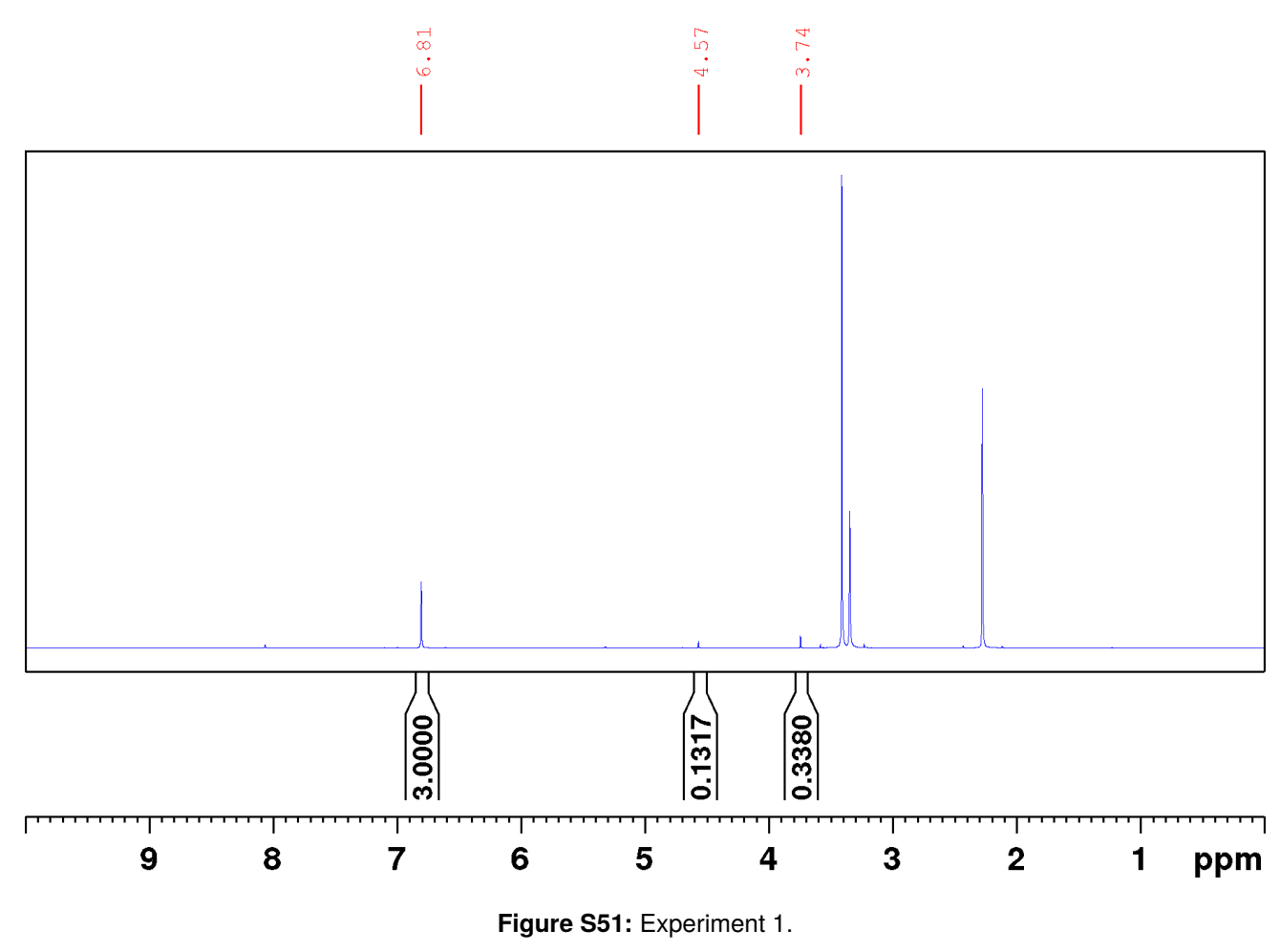




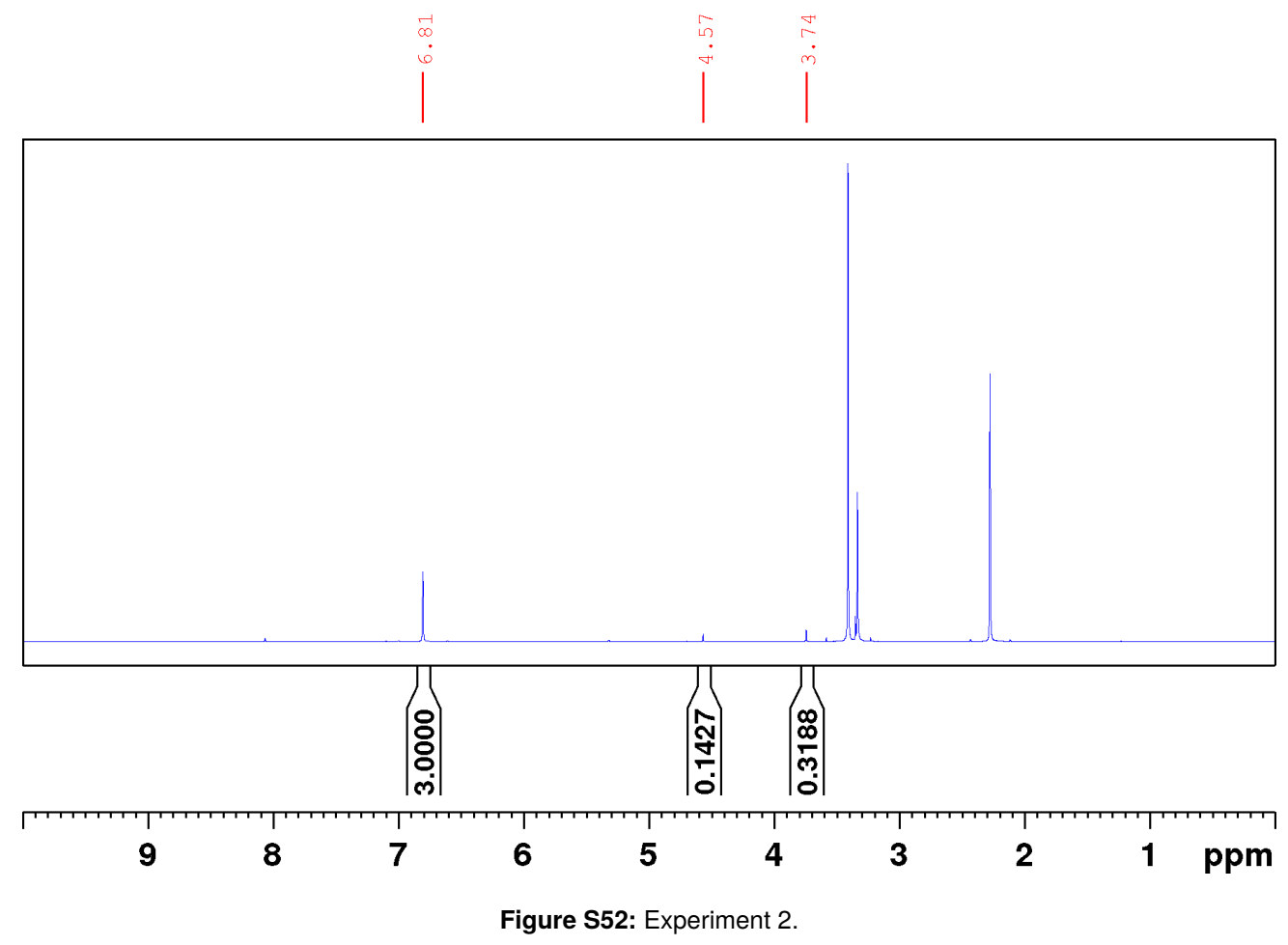




\section{Catalyst Loading: $0.1875 \mu \mathrm{mol}$}

$$
\begin{aligned}
T & =90^{\circ} \mathrm{C} & n_{\mathrm{cat}} & =0.1875 \mu \mathrm{mol} \\
p_{\mathrm{H} 2} & =90 \mathrm{bar} & n_{\mathrm{add}} & =0.78125 \mu \mathrm{mol} \\
p_{\mathrm{CO} 2} & =20 \mathrm{bar} & \text { add } & =\mathrm{Al}(\mathrm{OTf})_{3} \\
t & =18 \mathrm{~h} & V_{\mathrm{MeOH}} & =0.5 \mathrm{~mL}
\end{aligned}
$$

\begin{tabular}{|c|c|c|c|c|c|}
\hline & Integral $_{\mathrm{DMM}}$ & $\mathrm{TON}_{\mathrm{DMM}}$ & Integral $_{\mathrm{MF}}$ & $\mathrm{TON}_{\mathrm{MF}}$ & Ratio \\
\hline Experiment 1 & 0.0478 & 321 & 0.2905 & 1299 & 0.25 \\
\hline Experiment 2 & 0.0534 & 358 & 0.3217 & 1439 & 0.25 \\
\hline Average & - & $339(27)$ & - & 1369(99) & $0.25(0.00)$ \\
\hline
\end{tabular}

Table S25: Catalyses results of catalyst $\left[\mathrm{Ru}\left({ }^{\mathrm{Me}} S i\right.\right.$-triphos $\left.\left.{ }^{\mathrm{Ph}}\right)(\mathrm{tmm})\right] \mathbf{2 b}$ at a catalyst loading of $0.1875 \mu \mathrm{mol}$.






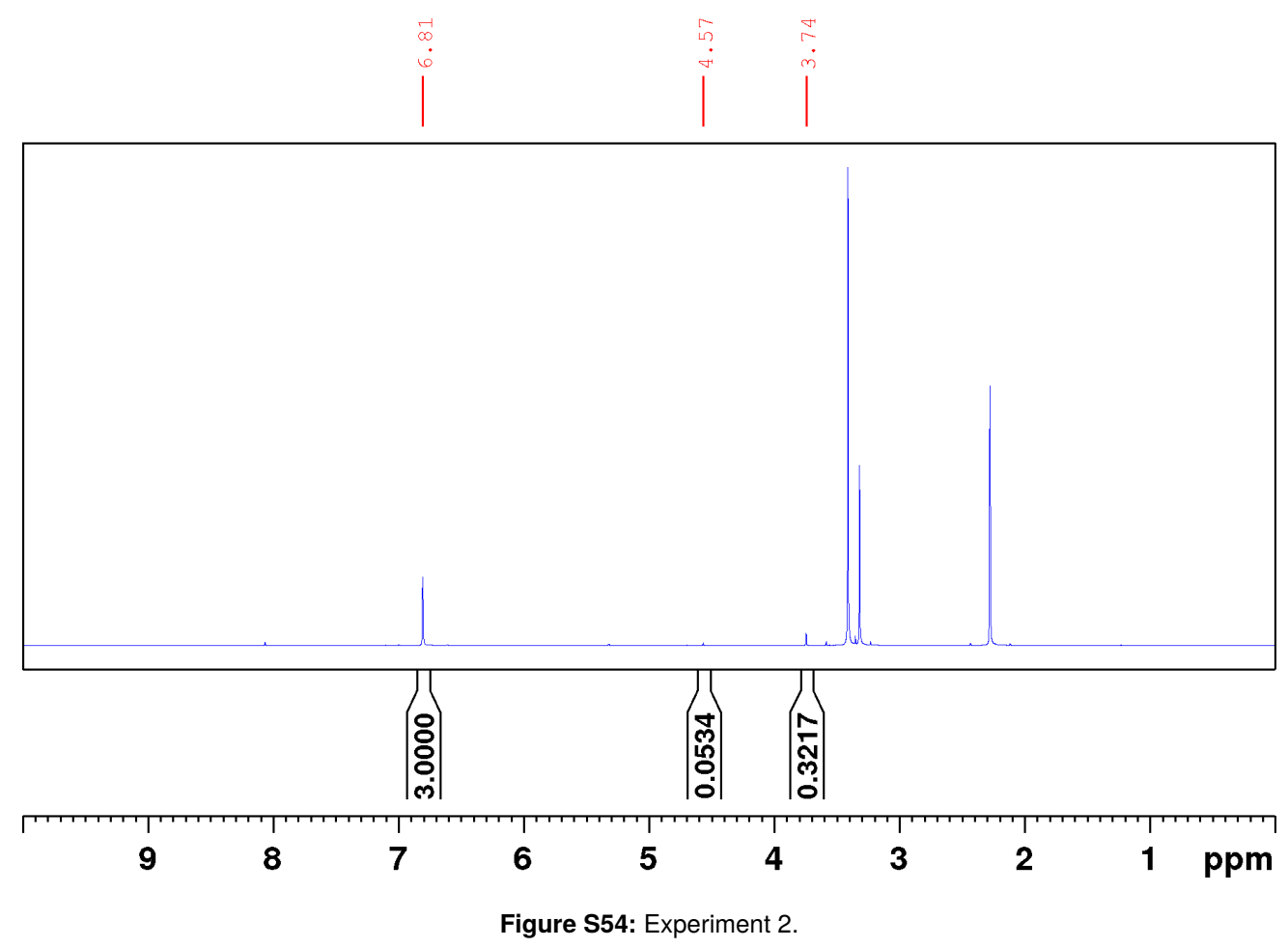




\section{Catalyst Loading: $0.375 \mu \mathrm{mol}$}

$$
\begin{aligned}
\mathrm{T} & =90^{\circ} \mathrm{C} & n_{\mathrm{cat}} & =0.375 \mu \mathrm{mol} \\
p_{\mathrm{H} 2} & =90 \mathrm{bar} & n_{\mathrm{add}} & =1.5625 \mu \mathrm{mol} \\
p_{\mathrm{CO} 2} & =20 \mathrm{bar} & \text { add } & =\mathrm{Al}(\mathrm{OTf})_{3} \\
t & =18 \mathrm{~h} & V_{\mathrm{MeOH}} & =0.5 \mathrm{~mL}
\end{aligned}
$$

Table S26: Catalyses results of catalyst $\left[\mathrm{Ru}\left({ }^{\mathrm{Me}} \mathrm{Si}\right.\right.$-triphos $\left.\left.{ }^{\mathrm{Ph}}\right)(\mathrm{tmm})\right] \mathbf{2 b}$ at a catalyst loading of $0.375 \mu \mathrm{mol}$.

\begin{tabular}{lccccc}
\hline & Integral $_{\mathrm{DMM}}$ & $\mathrm{TON}_{\mathrm{DMM}}$ & Integral $_{\mathrm{MF}}$ & TON $_{\mathrm{MF}}$ & Ratio \\
\hline Experiment 1 & 0.1438 & 482 & 0.2831 & 633 & 0.76 \\
Experiment 2 & 0.1591 & 534 & 0.2699 & 604 & 0.88 \\
Average & - & $508(37)$ & - & $619(21)$ & $0.82(0.09)$ \\
\hline
\end{tabular}

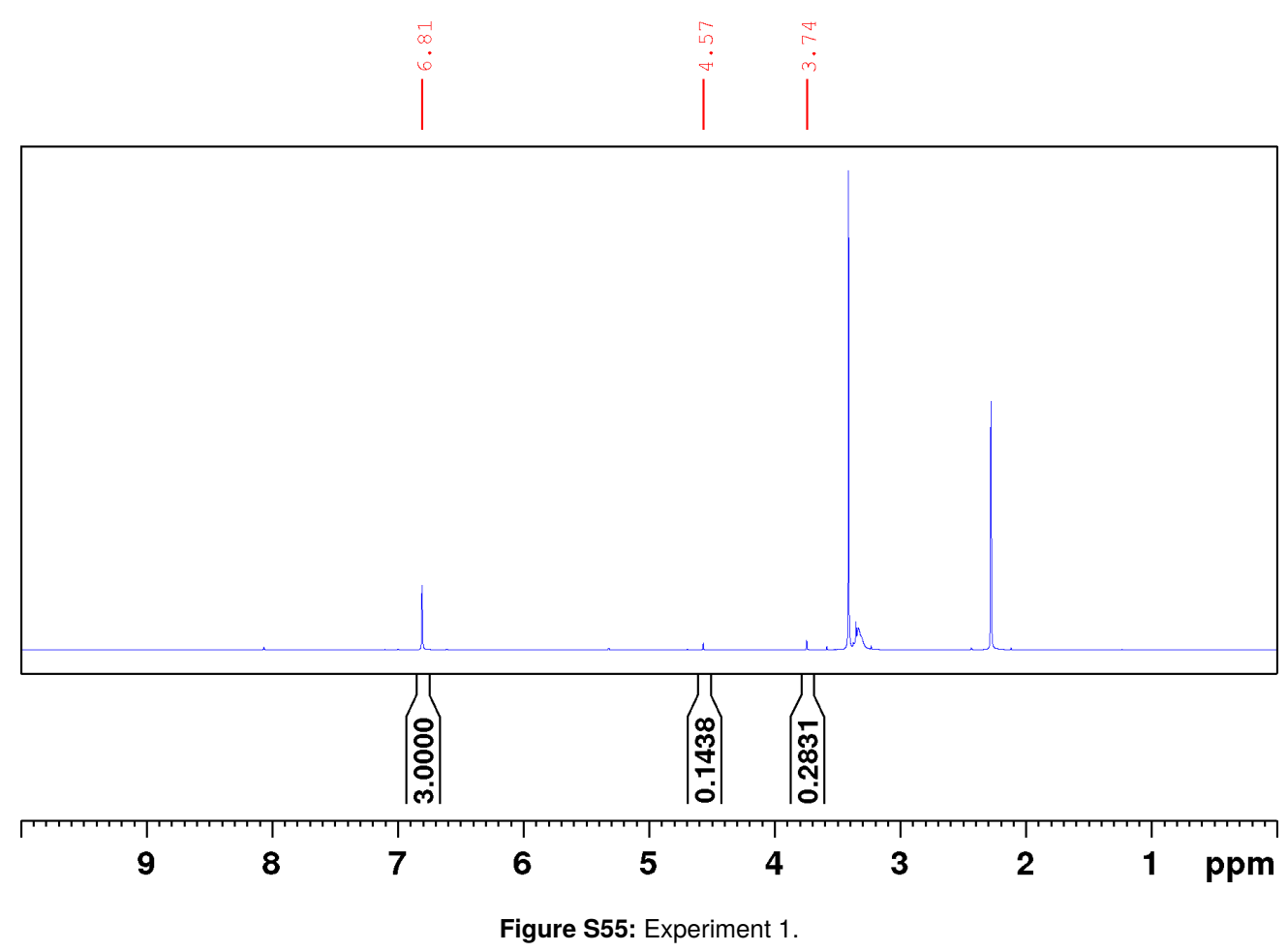




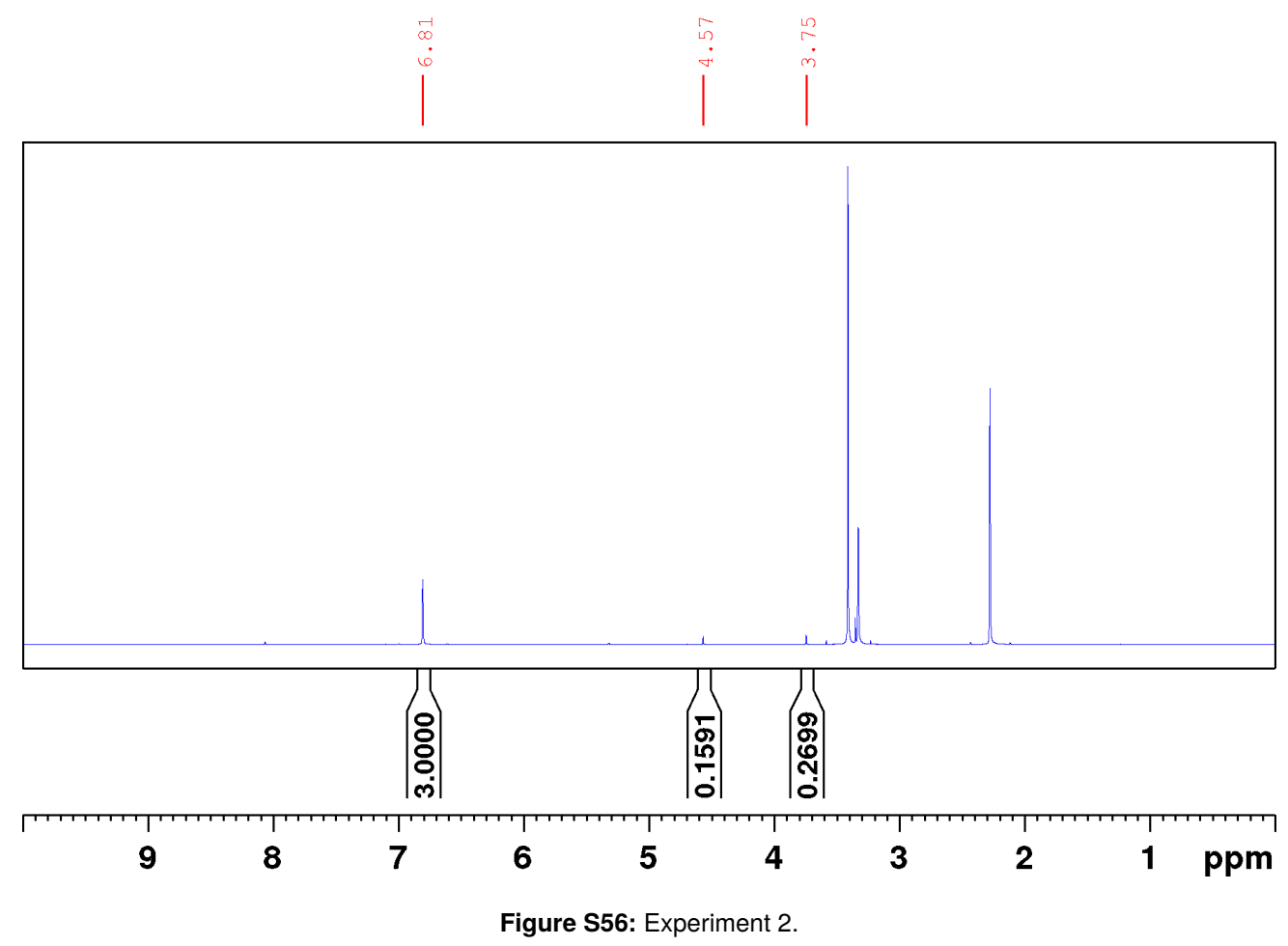




\section{Catalyst Loading: $0.75 \mu \mathrm{mol}$}

$$
\begin{aligned}
T & =90^{\circ} \mathrm{C} & n_{\text {cat }} & =0.75 \mu \mathrm{mol} \\
p_{\mathrm{H} 2} & =90 \mathrm{bar} & n_{\mathrm{add}} & =3.125 \mu \mathrm{mol} \\
p_{\mathrm{CO} 2} & =20 \mathrm{bar} & \text { add } & =\mathrm{Al}(\mathrm{OTf})_{3} \\
t & =18 \mathrm{~h} & V_{\mathrm{MeOH}} & =0.5 \mathrm{~mL}
\end{aligned}
$$

Table S27: Catalyses results of catalyst $\left[\mathrm{Ru}\left({ }^{\mathrm{Me}} \mathrm{Si}-\right.\right.$ triphos $\left.\left.^{\mathrm{Ph}}\right)(\mathrm{tmm})\right] \mathbf{2 b}$ at a catalyst loading of $0.75 \mu \mathrm{mol}$.

\begin{tabular}{lccccc}
\hline & Integral $_{\mathrm{DMM}}$ & TON $_{\mathrm{DMM}}$ & Integral $_{\mathrm{MF}}$ & TON $_{\mathrm{MF}}$ & Ratio \\
\hline Experiment 1 & 0.2092 & 351 & 0.1345 & 150 & 2.33 \\
Experiment 2 & 0.2367 & 397 & 0.1967 & 220 & 1.81 \\
Average & - & $374(33)$ & - & $185(49)$ & $2.07(0.37)$ \\
\hline
\end{tabular}

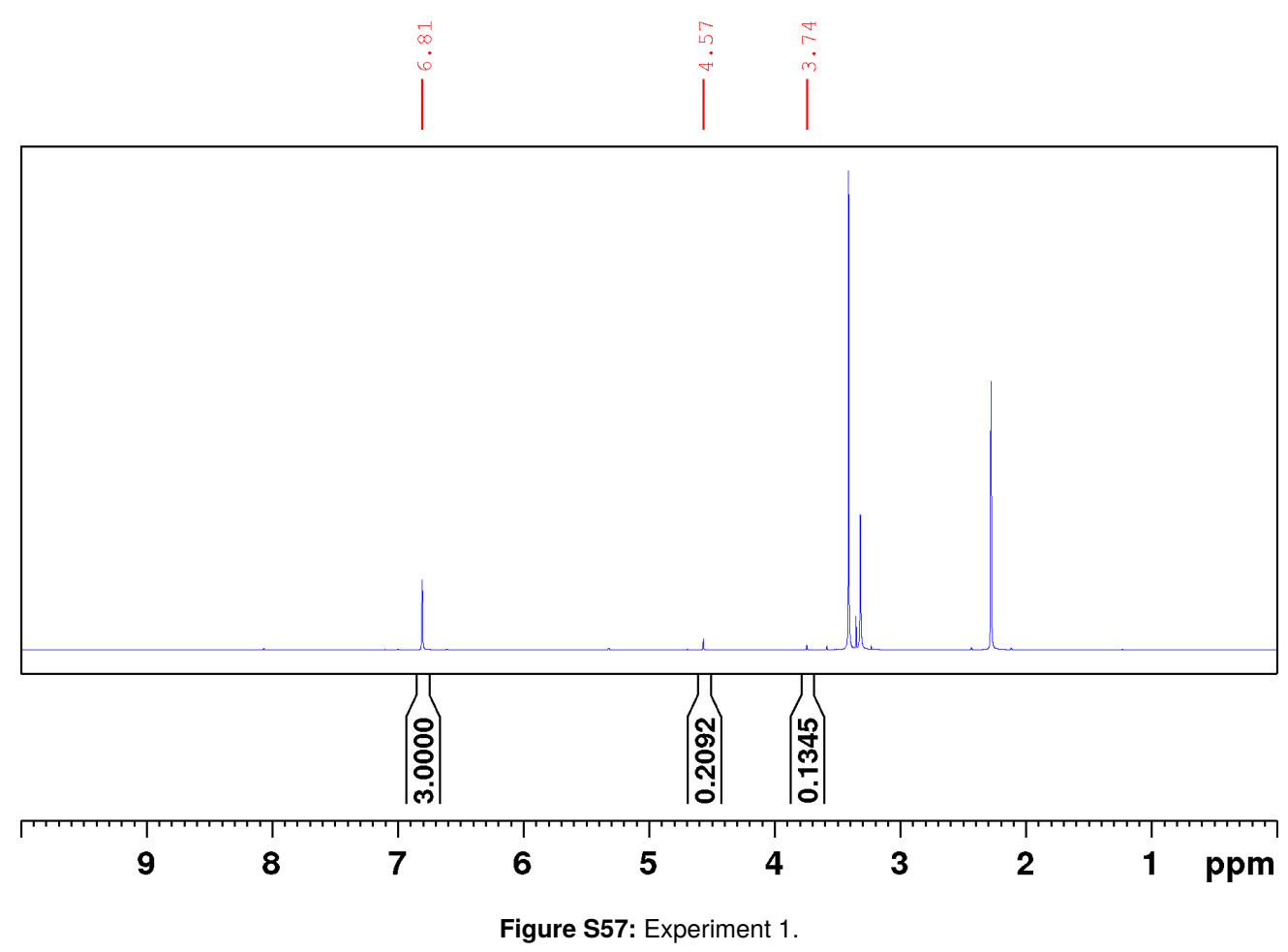




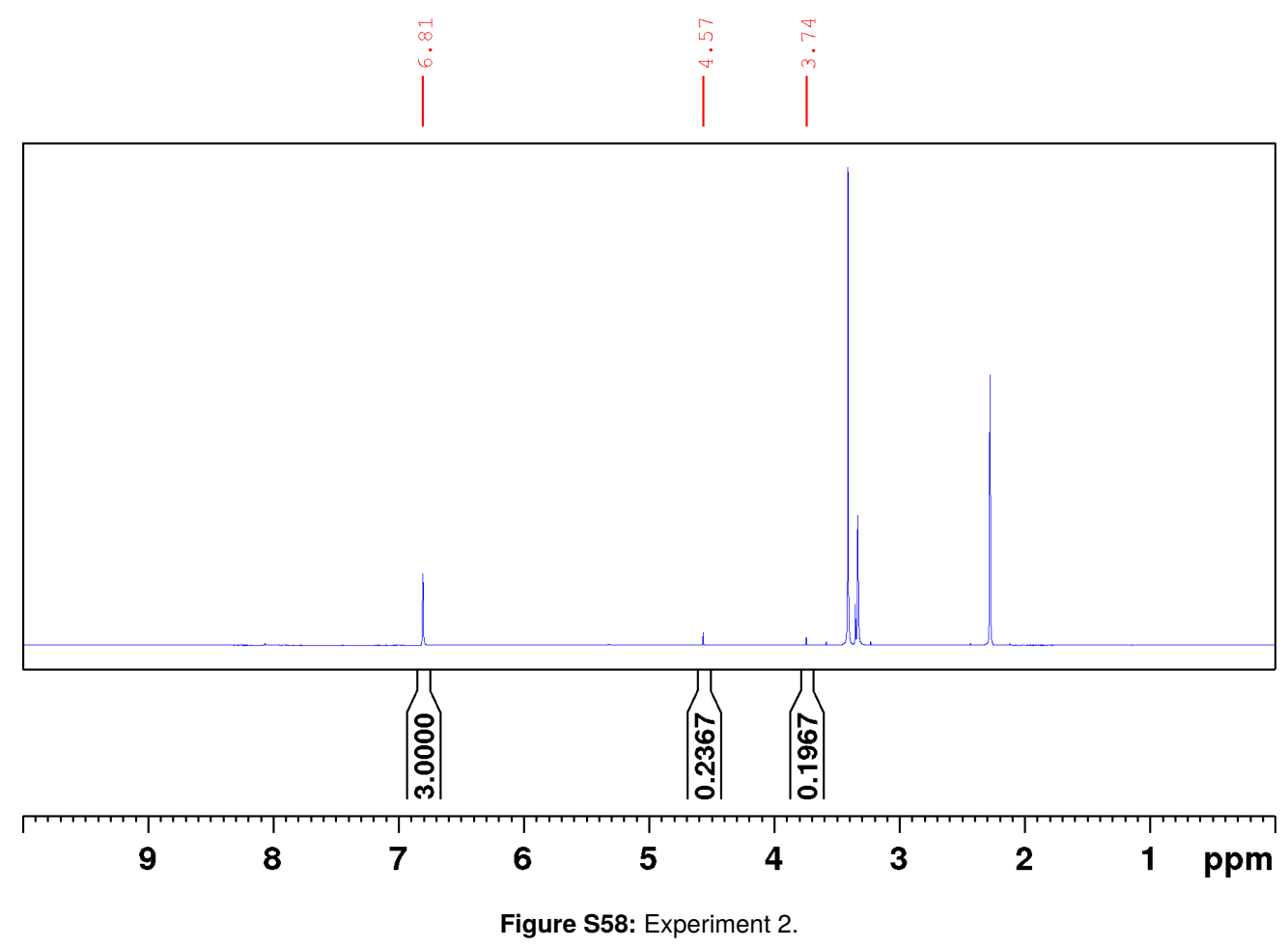




\section{Additive Loading: $0.78125 \mu \mathrm{mol}$}

$$
\begin{aligned}
\mathrm{T} & =90^{\circ} \mathrm{C} & n_{\mathrm{cat}} & =0.375 \mu \mathrm{mol} \\
p_{\mathrm{H} 2} & =90 \mathrm{bar} & n_{\mathrm{add}} & =0.78125 \mu \mathrm{mol} \\
p_{\mathrm{CO} 2} & =20 \mathrm{bar} & \text { add } & =\mathrm{Al}(\mathrm{OTf})_{3} \\
t & =18 \mathrm{~h} & V_{\mathrm{MeOH}} & =0.5 \mathrm{~mL}
\end{aligned}
$$

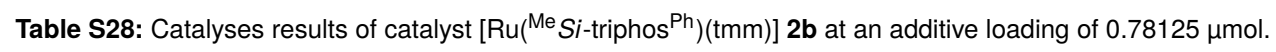

\begin{tabular}{lccccc}
\hline & Integral $_{\mathrm{DMM}}$ & TON $_{\mathrm{DMM}}$ & Integral $_{\mathrm{MF}}$ & TON $_{\mathrm{MF}}$ & Ratio \\
\hline Experiment 1 & 0.0770 & 258 & 0.2943 & 658 & 0.39 \\
Experiment 2 & 0.0768 & 258 & 0.2678 & 599 & 0.43 \\
Average & - & $258(0)$ & - & $629(42)$ & $0.41(0.03)$ \\
\hline
\end{tabular}






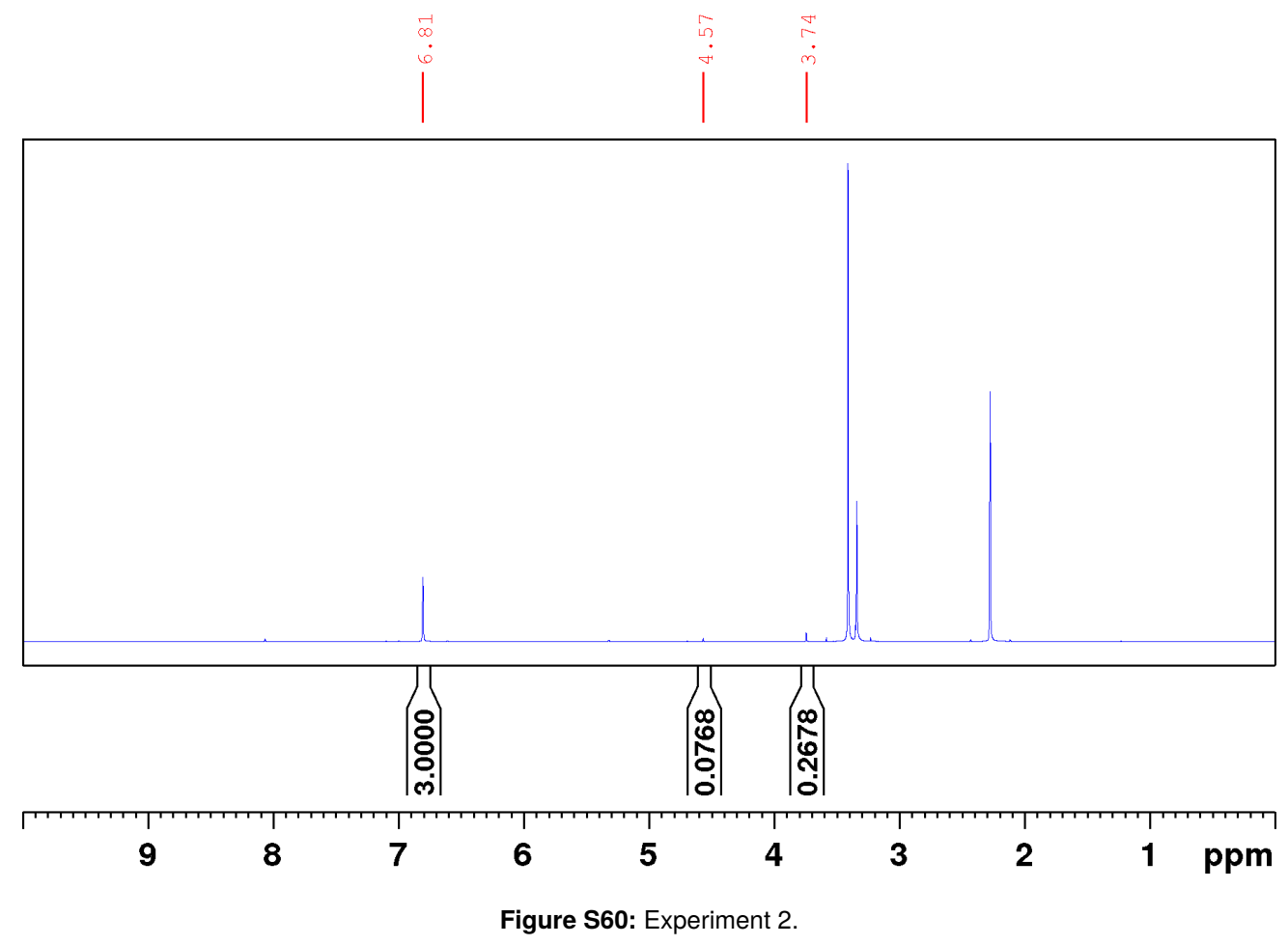




\section{Additive Loading: $1.5625 \mu \mathrm{mol}$}

$$
\begin{aligned}
T & =90^{\circ} \mathrm{C} & n_{\text {cat }} & =0.375 \mu \mathrm{mol} \\
p_{\mathrm{H} 2} & =90 \mathrm{bar} & n_{\text {add }} & =1.5625 \mu \mathrm{mol} \\
p_{\mathrm{CO} 2} & =20 \mathrm{bar} & \text { add } & =\mathrm{Al}(\mathrm{OTf})_{3} \\
t & =18 \mathrm{~h} & V_{\mathrm{MeOH}} & =0.5 \mathrm{~mL}
\end{aligned}
$$

Table S29: Catalyses results of catalyst $\left[\mathrm{Ru}\left({ }^{\mathrm{Me}} \mathrm{Si}\right.\right.$-triphos $\left.\left.{ }^{\mathrm{Ph}}\right)(\mathrm{tmm})\right] \mathbf{2 b}$ at an additive loading of $1.5625 \mu \mathrm{mol}$.

\begin{tabular}{lccccc}
\hline & Integral $_{\mathrm{DMM}}$ & TON $_{\mathrm{DMM}}$ & Integral $_{\mathrm{MF}}$ & TON $_{\mathrm{MF}}$ & Ratio \\
\hline Experiment 1 & 0.1438 & 482 & 0.2831 & 633 & 0.76 \\
Experiment 2 & 0.1591 & 534 & 0.2699 & 604 & 0.88 \\
Average & - & $508(37)$ & - & $619(21)$ & $0.82(0.09)$ \\
\hline
\end{tabular}

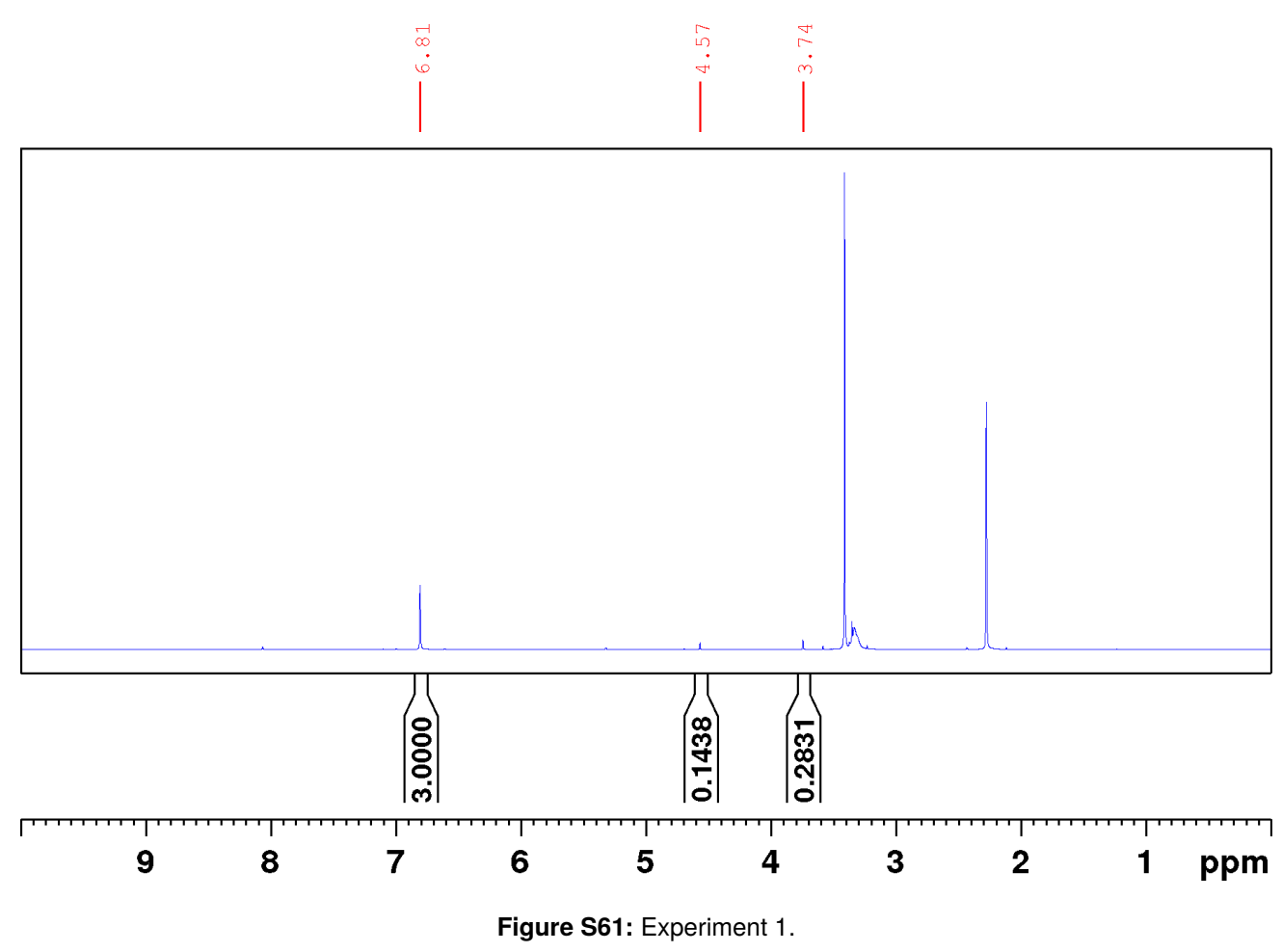




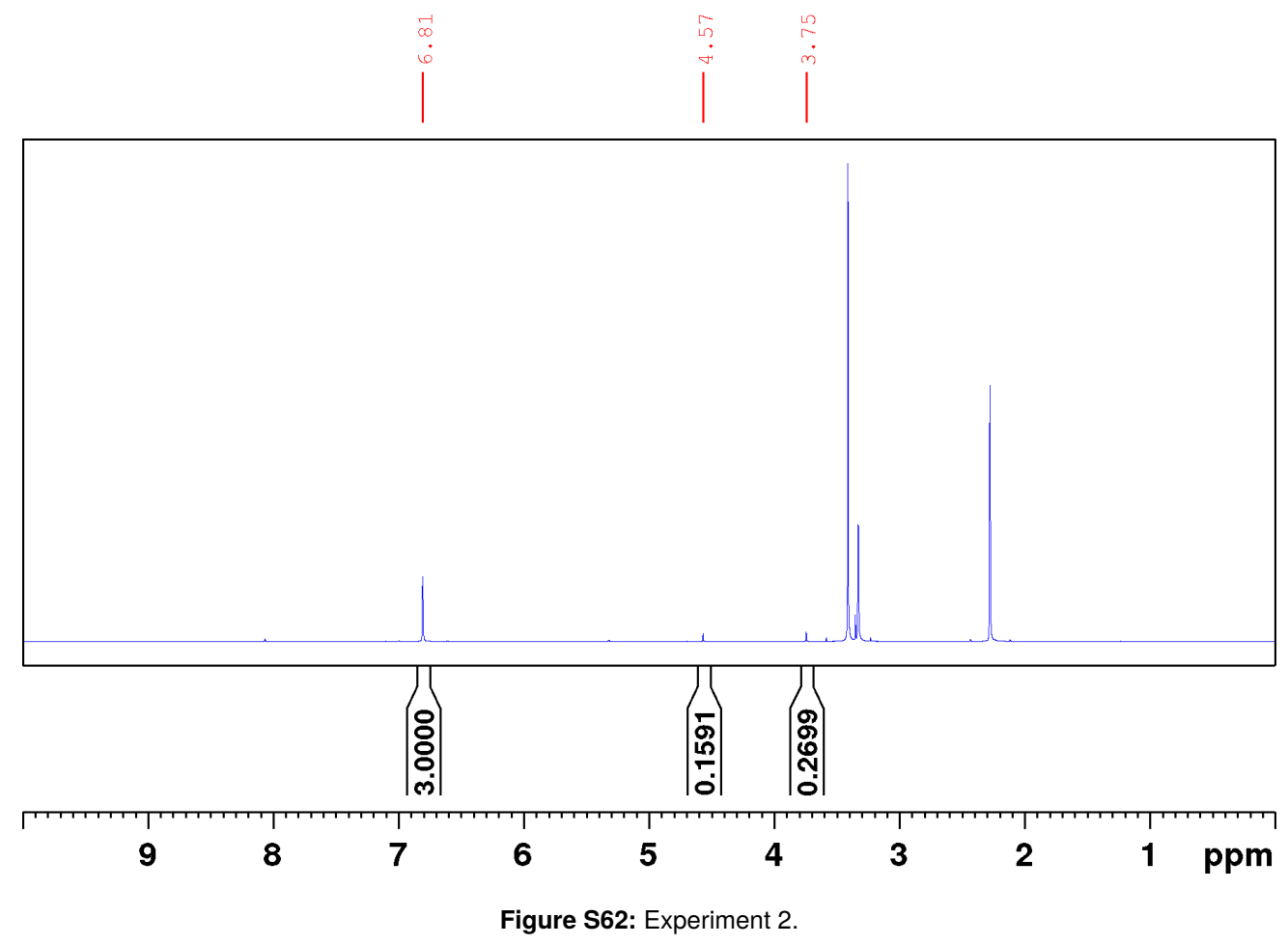




\section{Additive Loading: $3.125 \mu \mathrm{mol}$}

$$
\begin{aligned}
T & =90^{\circ} \mathrm{C} & n_{\text {cat }} & =0.375 \mu \mathrm{mol} \\
p_{\mathrm{H} 2} & =90 \mathrm{bar} & n_{\mathrm{add}} & =3.125 \mu \mathrm{mol} \\
p_{\mathrm{CO} 2} & =20 \mathrm{bar} & \text { add } & =\mathrm{Al}(\mathrm{OTf})_{3} \\
t & =18 \mathrm{~h} & V_{\mathrm{MeOH}} & =0.5 \mathrm{~mL}
\end{aligned}
$$

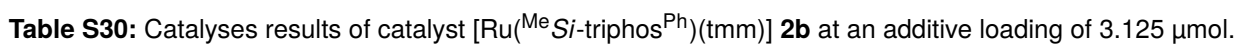

\begin{tabular}{lccccc}
\hline & Integral $_{\mathrm{DMM}}$ & $\mathrm{TON}_{\mathrm{DMM}}$ & Integral $_{\mathrm{MF}}$ & $\mathrm{TON}_{\mathrm{MF}}$ & Ratio \\
\hline Experiment 1 & 0.1903 & 638 & 0.1966 & 440 & 1.45 \\
Experiment 2 & 0.2178 & 731 & 0.2202 & 492 & 1.48 \\
Average & - & $685(65)$ & - & $466(37)$ & $1.47(0.02)$ \\
\hline
\end{tabular}











\subsection{3 $\left[R u\left(P\right.\right.$-triphos $\left.\left.{ }^{\mathrm{Ph}}\right)(\mathrm{tmm})\right] 2 \mathrm{c}$}

\section{Temperature: $80^{\circ} \mathrm{C}$}

$$
\begin{aligned}
\mathrm{T} & =80^{\circ} \mathrm{C} & n_{\mathrm{cat}} & =0.375 \mu \mathrm{mol} \\
p_{\mathrm{H} 2} & =90 \mathrm{bar} & n_{\mathrm{add}} & =1.5625 \mu \mathrm{mol} \\
p_{\mathrm{CO} 2} & =20 \mathrm{bar} & \text { add } & =\mathrm{Al}(\mathrm{OTf})_{3} \\
t & =18 \mathrm{~h} & V_{\mathrm{MeOH}} & =0.5 \mathrm{~mL}
\end{aligned}
$$

Table S31: Catalyses results of catalyst $\left[\mathrm{Ru}\left(P\right.\right.$-triphos $\left.\left.{ }^{\mathrm{Ph}}\right)(\mathrm{tmm})\right] 2 \mathrm{c}$ at $80^{\circ} \mathrm{C}$.

\begin{tabular}{lccccc}
\hline & Integral $_{\mathrm{DMM}}$ & $\mathrm{TON}_{\mathrm{DMM}}$ & Integral $_{\mathrm{MF}}$ & $\mathrm{TON}_{\mathrm{MF}}$ & Ratio \\
\hline Experiment 1 & 0.0700 & 235 & 0.2974 & 665 & 0.35 \\
Experiment 2 & 0.0681 & 228 & 0.3124 & 699 & 0.33 \\
Average & - & $232(5)$ & - & $682(24)$ & $0.34(0.02)$ \\
\hline
\end{tabular}

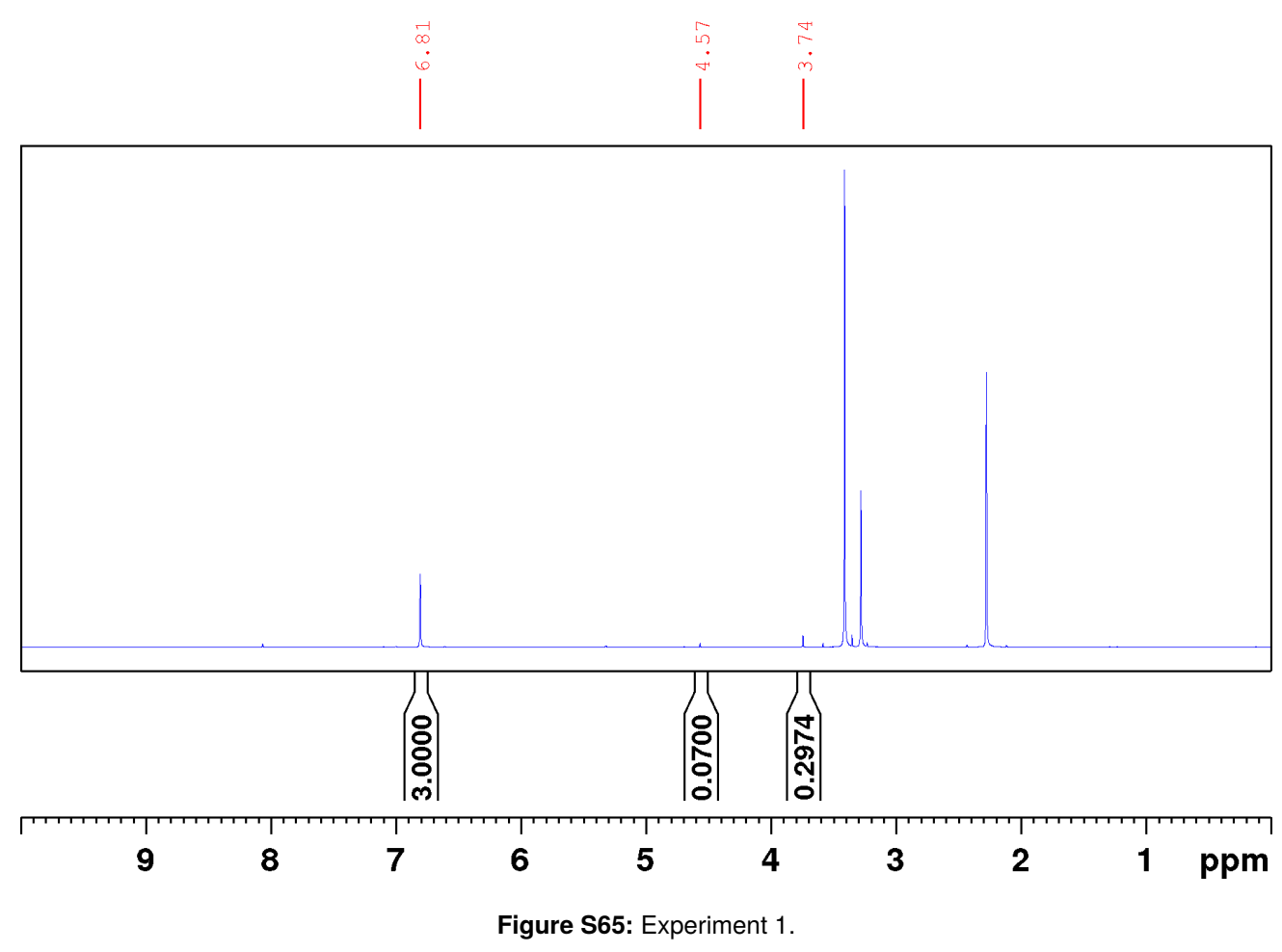




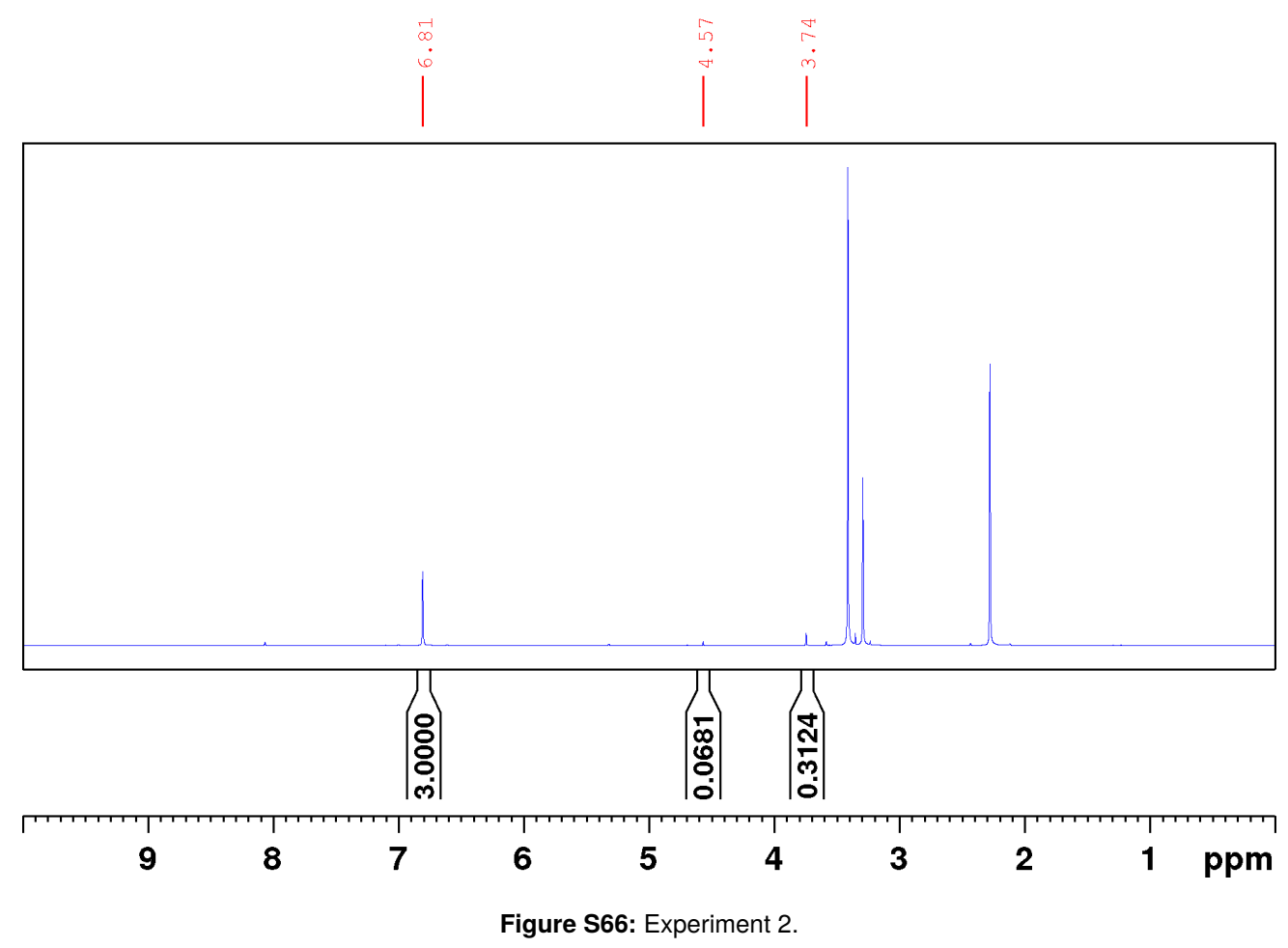




\section{Temperature: $90^{\circ} \mathrm{C}$}

$$
\begin{array}{rlrl}
\mathrm{T} & =90^{\circ} \mathrm{C} & n_{\text {cat }} & =0.375 \mu \mathrm{mol} \\
p_{\mathrm{H} 2} & =90 \mathrm{bar} & n_{\text {add }} & =1.5625 \mu \mathrm{mol} \\
p_{\mathrm{CO} 2} & =20 \mathrm{bar} & \mathrm{add} & =\mathrm{Al}(\mathrm{OTf})_{3} \\
t & =18 \mathrm{~h} & V_{\mathrm{MeOH}} & =0.5 \mathrm{~mL}
\end{array}
$$

Table S32: Catalyses results of catalyst $\left[\mathrm{Ru}\left(P\right.\right.$-triphos $\left.\left.{ }^{\mathrm{Ph}}\right)(\mathrm{tmm})\right] 2 \mathrm{c}$ at $90^{\circ} \mathrm{C}$.

\begin{tabular}{lccccc}
\hline & Integral $_{\mathrm{DMM}}$ & $\mathrm{TON}_{\mathrm{DMM}}$ & Integral $_{\mathrm{MF}}$ & $\mathrm{TON}_{\mathrm{MF}}$ & Ratio \\
\hline Experiment 1 & 0.0960 & 322 & 0.2537 & 567 & 0.57 \\
Experiment 2 & 0.0924 & 310 & 0.2561 & 573 & 0.54 \\
Average & - & $316(8)$ & - & $570(4)$ & $0.55(0.02)$ \\
\hline
\end{tabular}

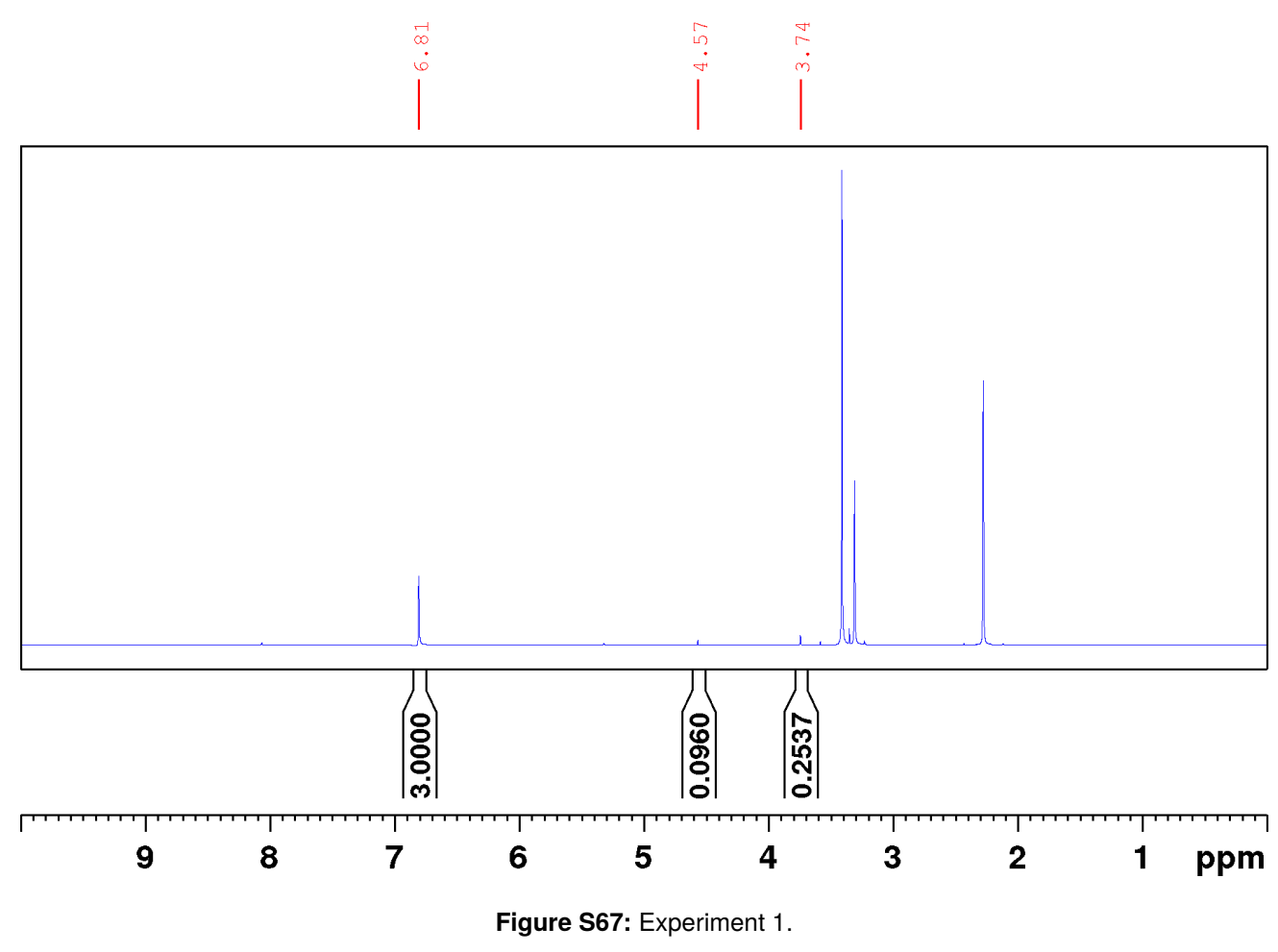




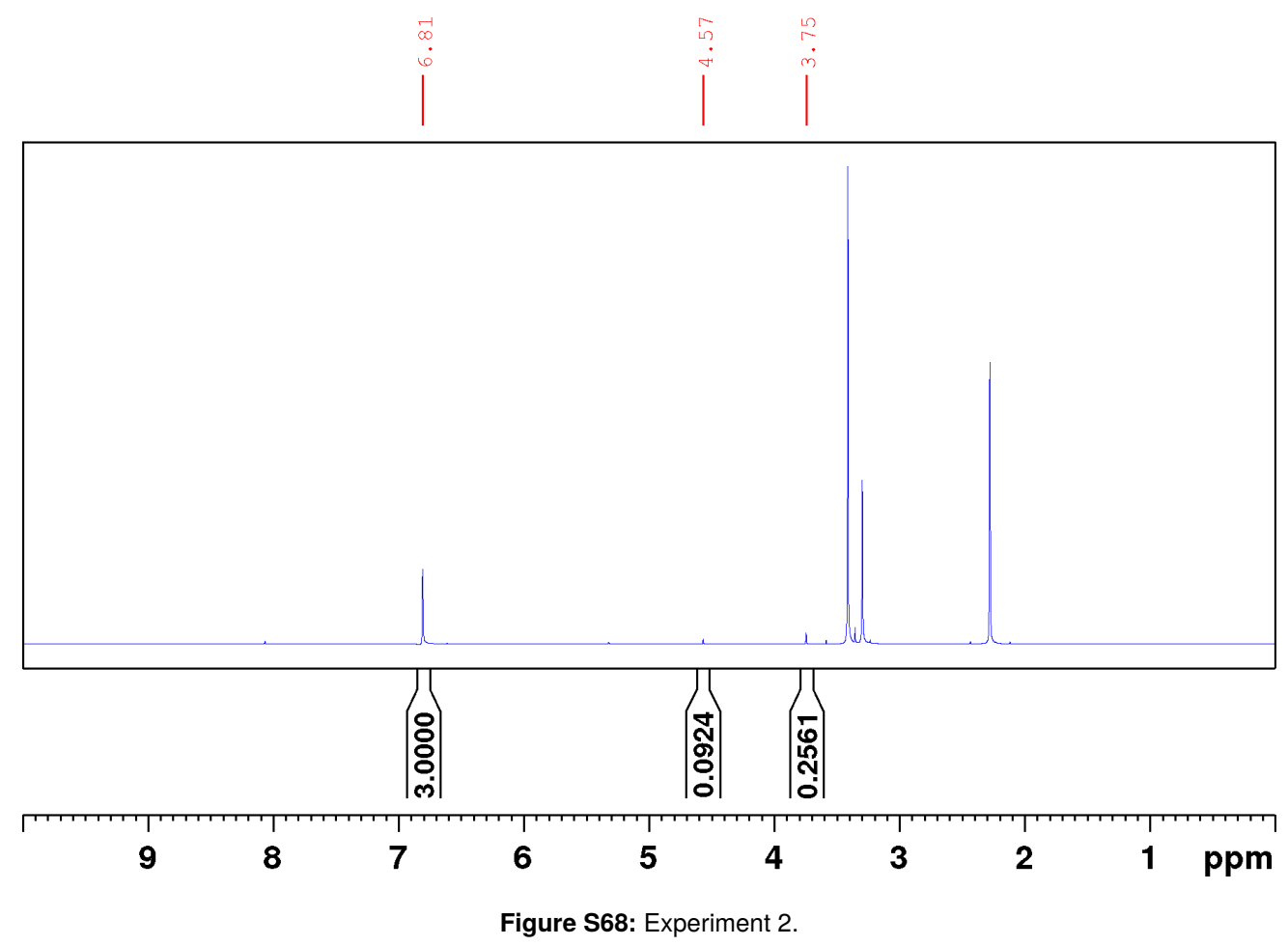


Temperature: $100^{\circ} \mathrm{C}$

$$
\begin{aligned}
T & =100{ }^{\circ} \mathrm{C} & n_{\text {cat }} & =0.375 \mu \mathrm{mol} \\
p_{\mathrm{H} 2} & =90 \mathrm{bar} & n_{\text {add }} & =1.5625 \mu \mathrm{mol} \\
p_{\mathrm{CO} 2} & =20 \mathrm{bar} & \text { add } & =\mathrm{Al}(\mathrm{OTf})_{3} \\
t & =18 \mathrm{~h} & V_{\mathrm{MeOH}} & =0.5 \mathrm{~mL}
\end{aligned}
$$

Table S33: Catalyses results of catalyst $\left[\mathrm{Ru}\left(P\right.\right.$-triphos $\left.\left.{ }^{\mathrm{Ph}}\right)(\mathrm{tmm})\right] 2 \mathrm{c}$ at $100^{\circ} \mathrm{C}$.

\begin{tabular}{lccccc}
\hline & Integral $_{\mathrm{DMM}}$ & $\mathrm{TON}_{\mathrm{DMM}}$ & Integral $_{\mathrm{MF}}$ & $\mathrm{TON}_{\mathrm{MF}}$ & Ratio \\
\hline Experiment 1 & 0.1160 & 389 & 0.2429 & 543 & 0.72 \\
Experiment 2 & 0.1066 & 358 & 0.2387 & 534 & 0.67 \\
Average & - & $374(22)$ & - & $539(6)$ & $0.69(0.03)$ \\
\hline
\end{tabular}

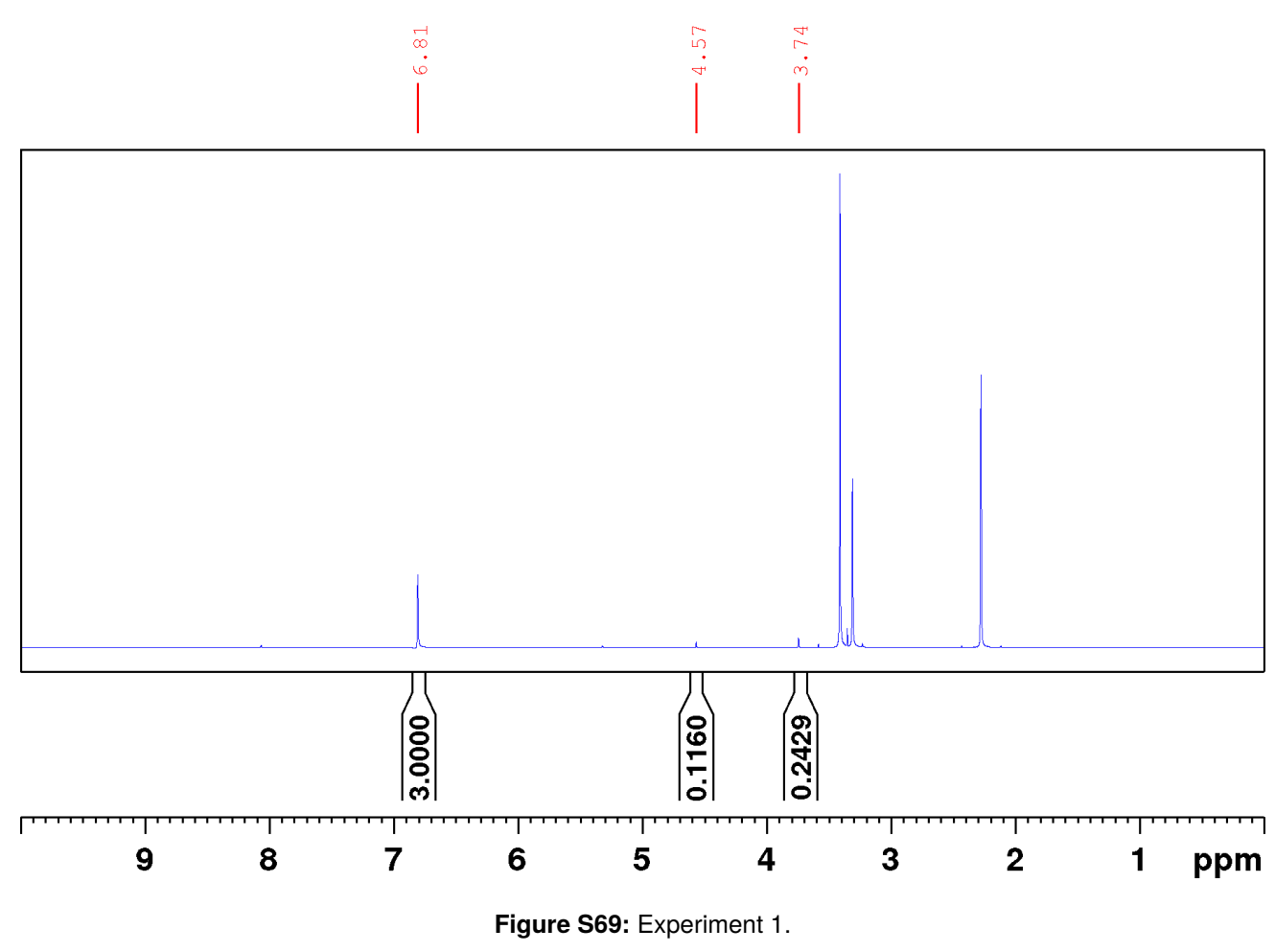




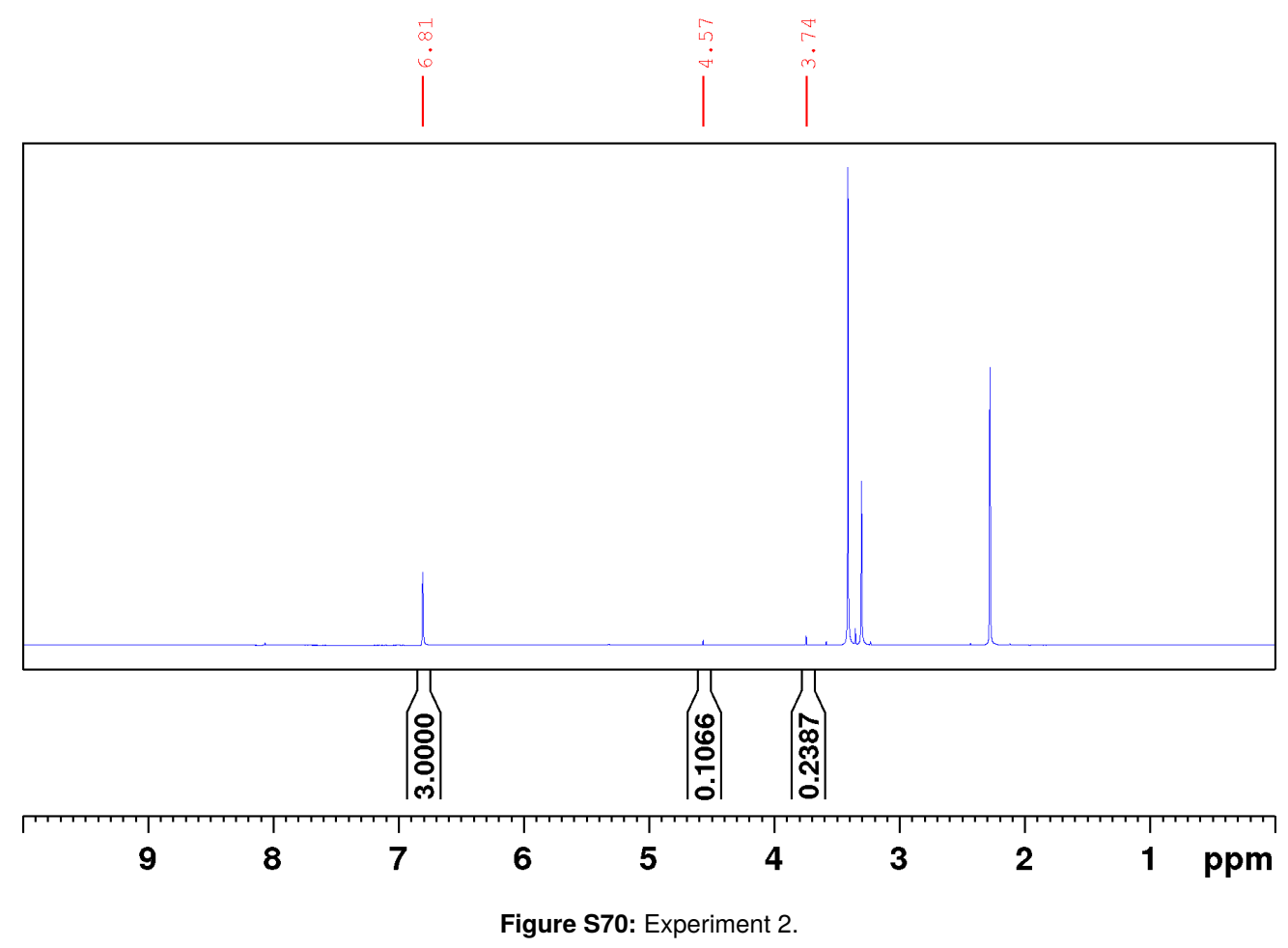




\section{$\mathrm{H}_{2}$ Pressure: 80 bar}

$$
\begin{aligned}
\mathrm{T} & =100{ }^{\circ} \mathrm{C} & n_{\text {cat }} & =0.375 \mu \mathrm{mol} \\
p_{\mathrm{H} 2} & =80 \mathrm{bar} & n_{\text {add }} & =1.5625 \mu \mathrm{mol} \\
p_{\mathrm{CO} 2} & =20 \mathrm{bar} & \text { add } & =\mathrm{Al}(\mathrm{OTf})_{3} \\
t & =18 \mathrm{~h} & V_{\mathrm{MeOH}} & =0.5 \mathrm{~mL}
\end{aligned}
$$

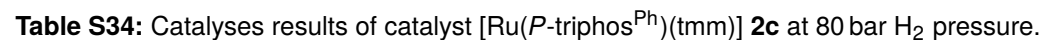

\begin{tabular}{lccccc}
\hline & Integral $_{\mathrm{DMM}}$ & $\mathrm{TON}_{\mathrm{DMM}}$ & Integral $_{\mathrm{MF}}$ & $\mathrm{TON}_{\mathrm{MF}}$ & Ratio \\
\hline Experiment 1 & 0.1085 & 364 & 0.2556 & 572 & 0.64 \\
Experiment 2 & 0.0987 & 331 & 0.2694 & 603 & 0.55 \\
Average & - & $348(23)$ & - & $588(22)$ & $0.59(0.06)$ \\
\hline
\end{tabular}

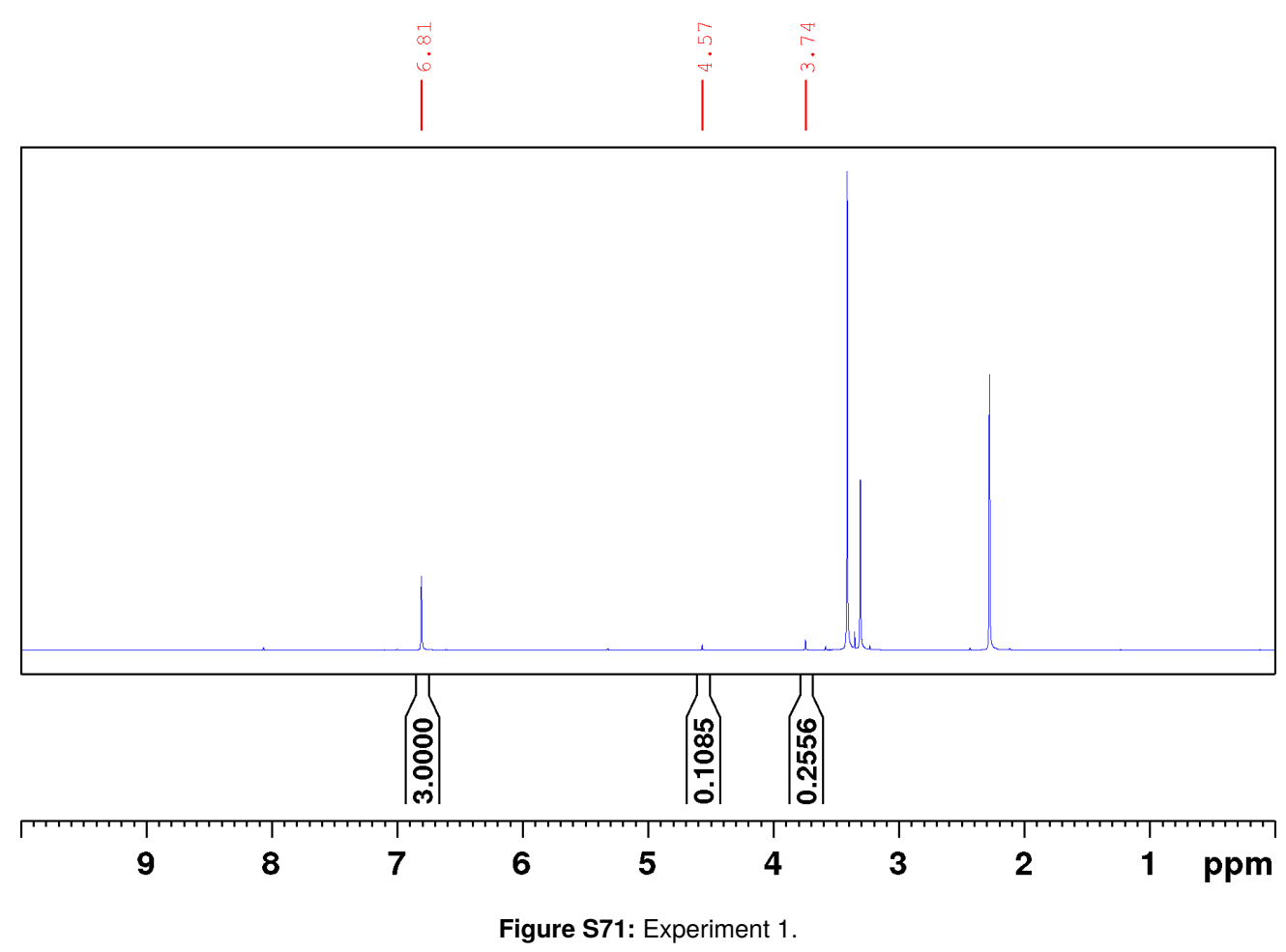




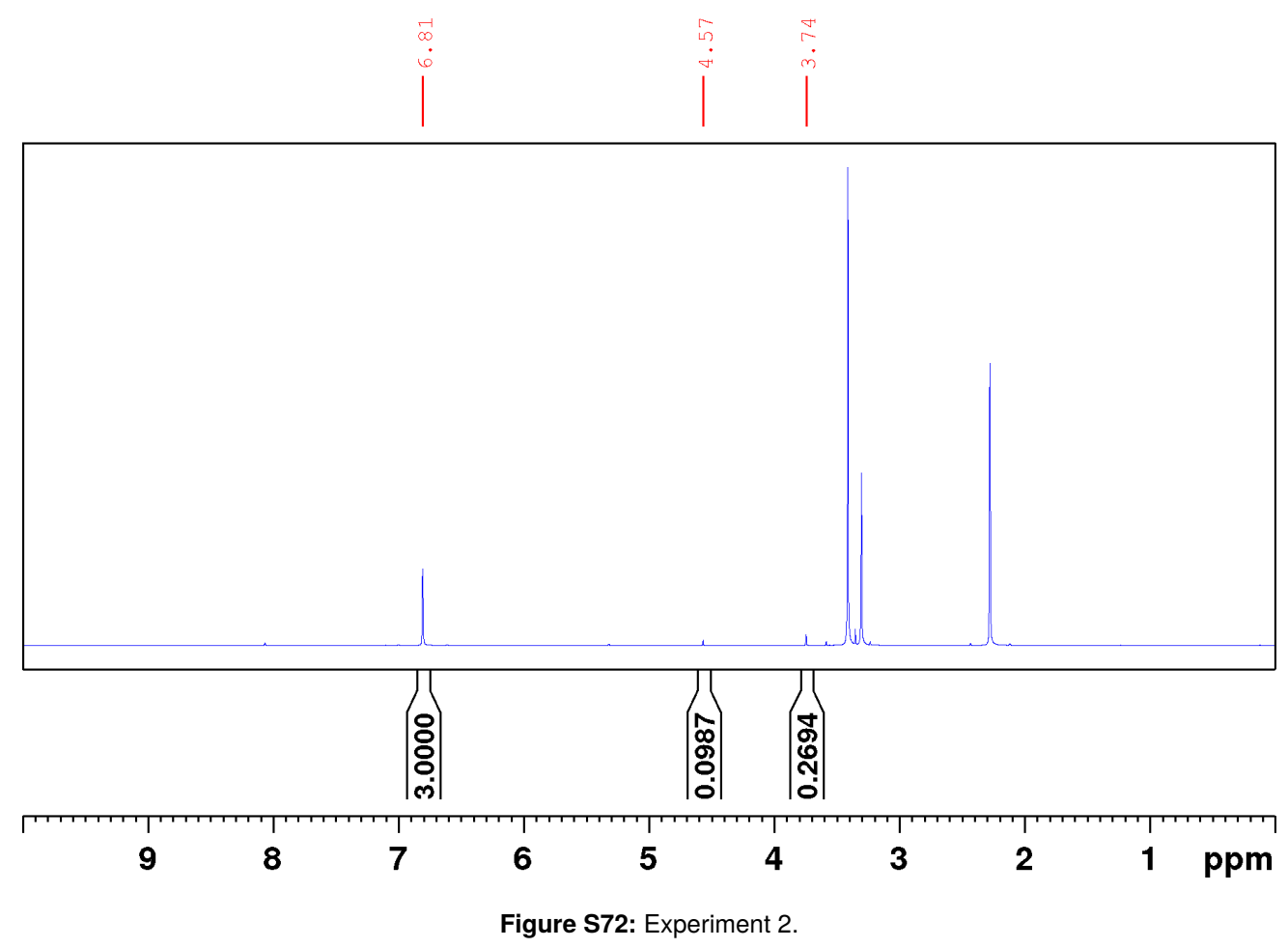




\section{$\mathrm{H}_{2}$ Pressure: 90 bar}

$$
\begin{aligned}
\mathrm{T} & =100{ }^{\circ} \mathrm{C} & n_{\text {cat }} & =0.375 \mu \mathrm{mol} \\
p_{\mathrm{H} 2} & =90 \mathrm{bar} & n_{\text {add }} & =1.5625 \mu \mathrm{mol} \\
p_{\mathrm{CO} 2} & =20 \mathrm{bar} & \text { add } & =\mathrm{Al}(\mathrm{OTf})_{3} \\
t & =18 \mathrm{~h} & V_{\mathrm{MeOH}} & =0.5 \mathrm{~mL}
\end{aligned}
$$

Table S35: Catalyses results of catalyst $\left[\mathrm{Ru}\left(P\right.\right.$-triphos $\left.\left.{ }^{\mathrm{Ph}}\right)(\mathrm{tmm})\right] 2 \mathrm{c}$ at 90 bar $\mathrm{H}_{2}$ pressure.

\begin{tabular}{lccccc}
\hline & Integral $_{\mathrm{DMM}}$ & TON $_{\mathrm{DMM}}$ & Integral $_{\mathrm{MF}}$ & TON $_{\mathrm{MF}}$ & Ratio \\
\hline Experiment 1 & 0.1160 & 389 & 0.2429 & 543 & 0.72 \\
Experiment 2 & 0.1066 & 358 & 0.2387 & 534 & 0.67 \\
Average & - & $374(22)$ & - & $539(6)$ & $0.69(0.03)$ \\
\hline
\end{tabular}

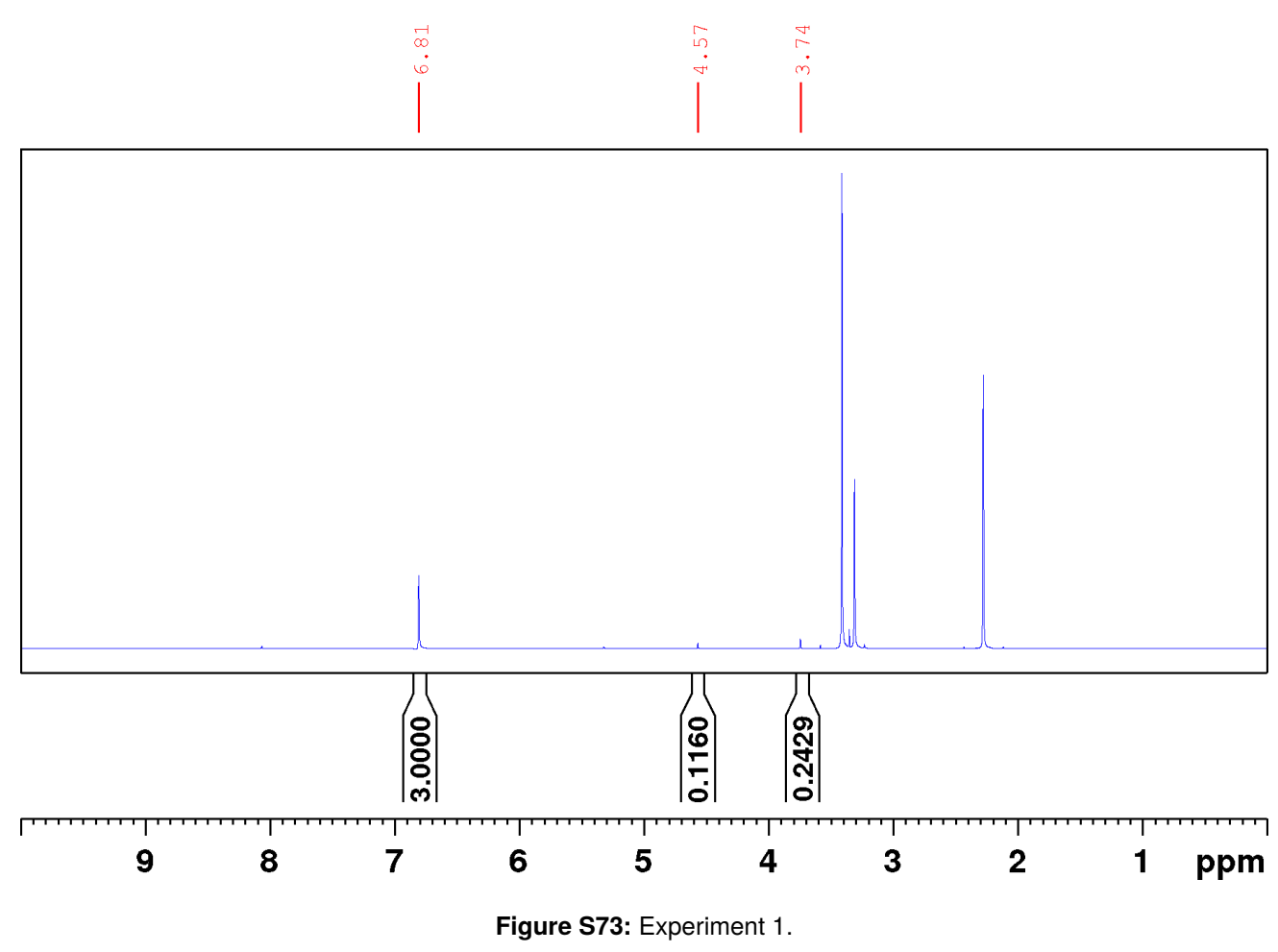




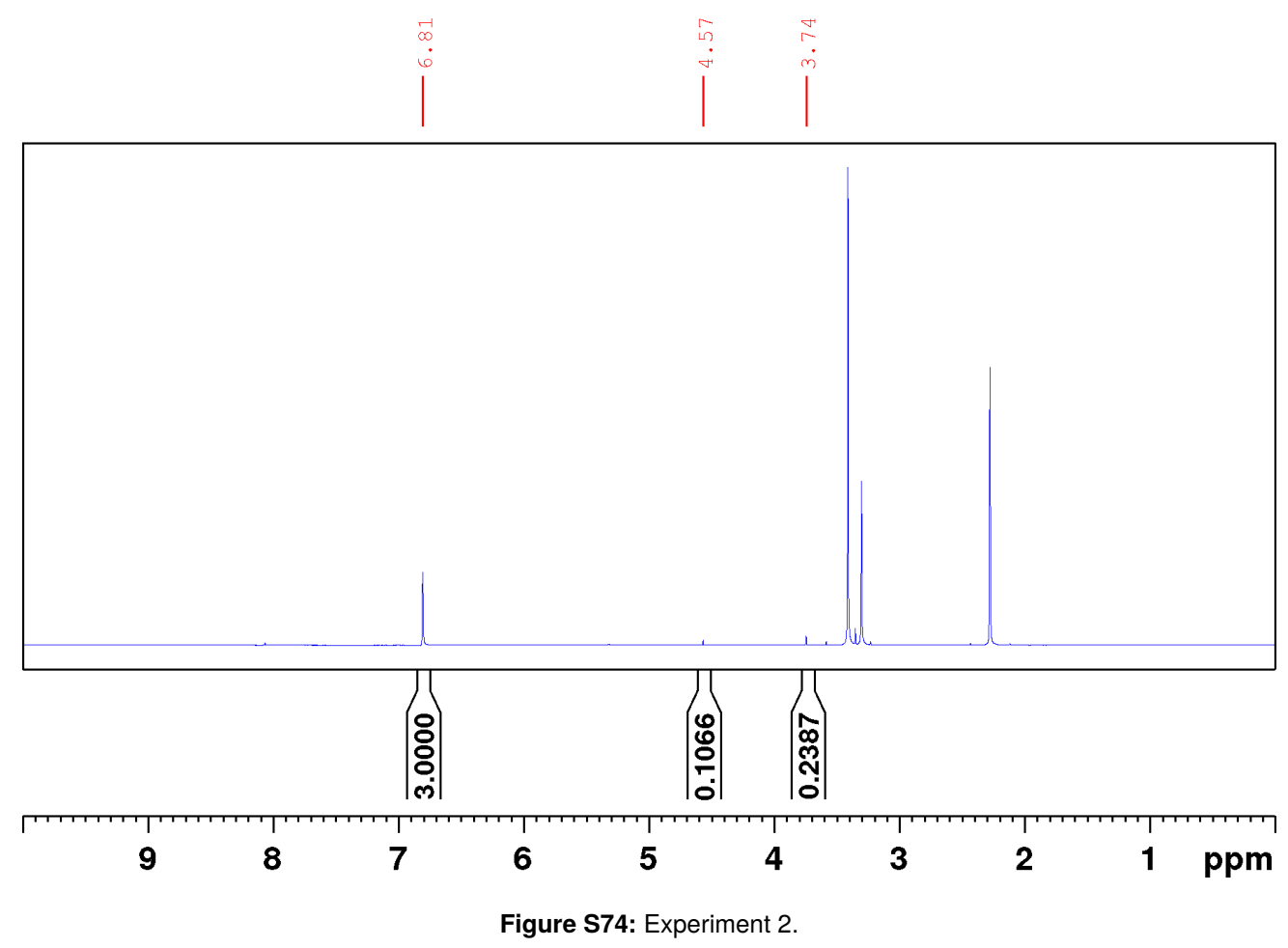


$H_{2}$ Pressure: 100 bar

$$
\begin{aligned}
T & =100{ }^{\circ} \mathrm{C} & n_{\text {cat }} & =0.375 \mu \mathrm{mol} \\
p_{\mathrm{H} 2} & =100 \mathrm{bar} & n_{\text {add }} & =1.5625 \mu \mathrm{mol} \\
p_{\mathrm{CO} 2} & =20 \mathrm{bar} & \text { add } & =\mathrm{Al}(\mathrm{OTf})_{3} \\
t & =18 \mathrm{~h} & V_{\mathrm{MeOH}} & =0.5 \mathrm{~mL}
\end{aligned}
$$

Table S36: Catalyses results of catalyst $\left[\mathrm{Ru}\left(P\right.\right.$-triphos $\left.\left.{ }^{\mathrm{Ph}}\right)(\mathrm{tmm})\right] \mathbf{2 c}$ at 100 bar $\mathrm{H}_{2}$ pressure.

\begin{tabular}{lccccc}
\hline & Integral $_{\mathrm{DMM}}$ & TON $_{\mathrm{DMM}}$ & Integral $_{\mathrm{MF}}$ & TON $_{\mathrm{MF}}$ & Ratio \\
\hline Experiment 1 & 0.1051 & 353 & 0.2645 & 592 & 0.60 \\
Experiment 2 & 0.0908 & 305 & 0.2485 & 556 & 0.55 \\
Average & - & $329(34)$ & - & $574(25)$ & $0.57(0.03)$ \\
\hline
\end{tabular}

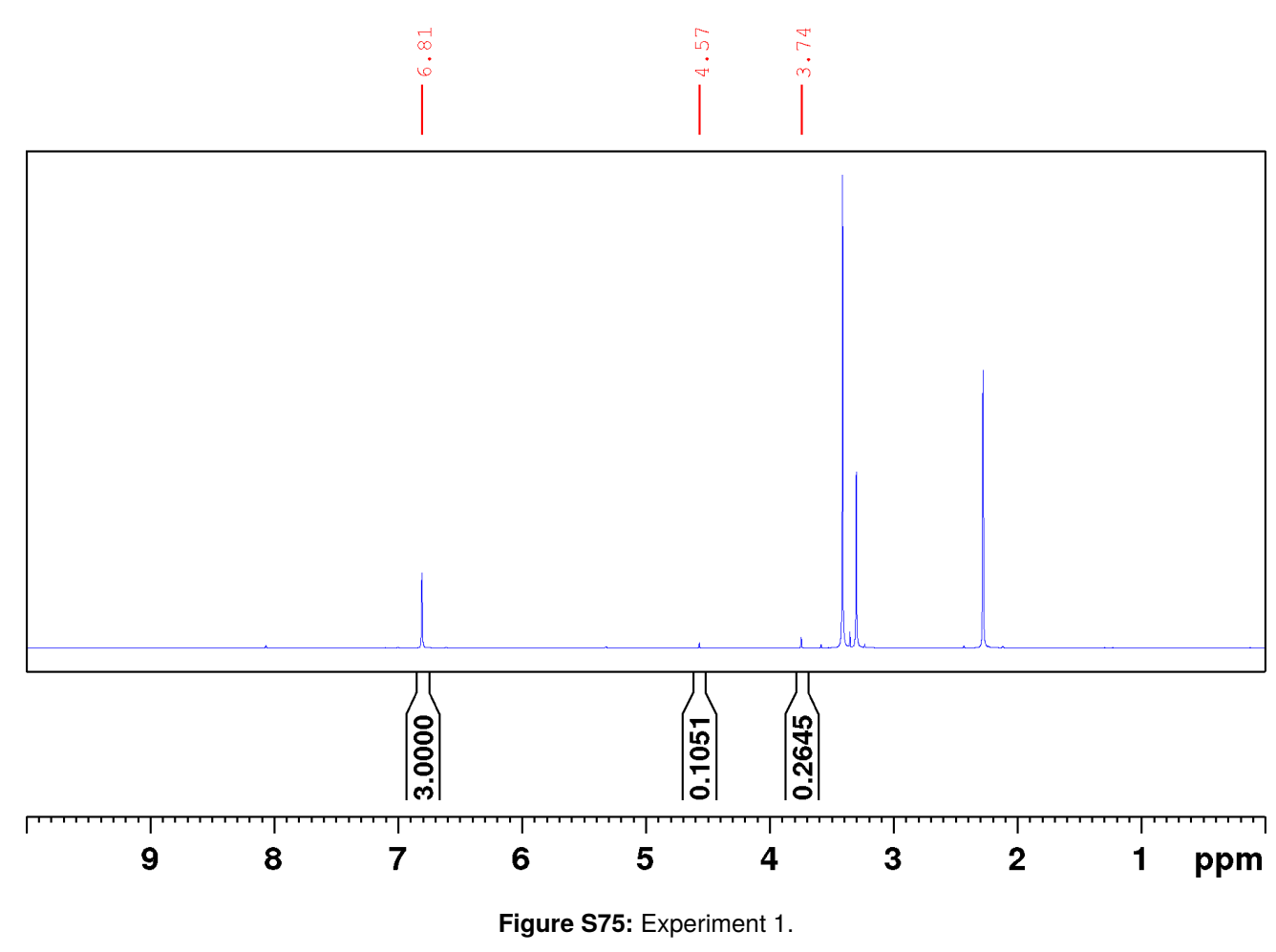




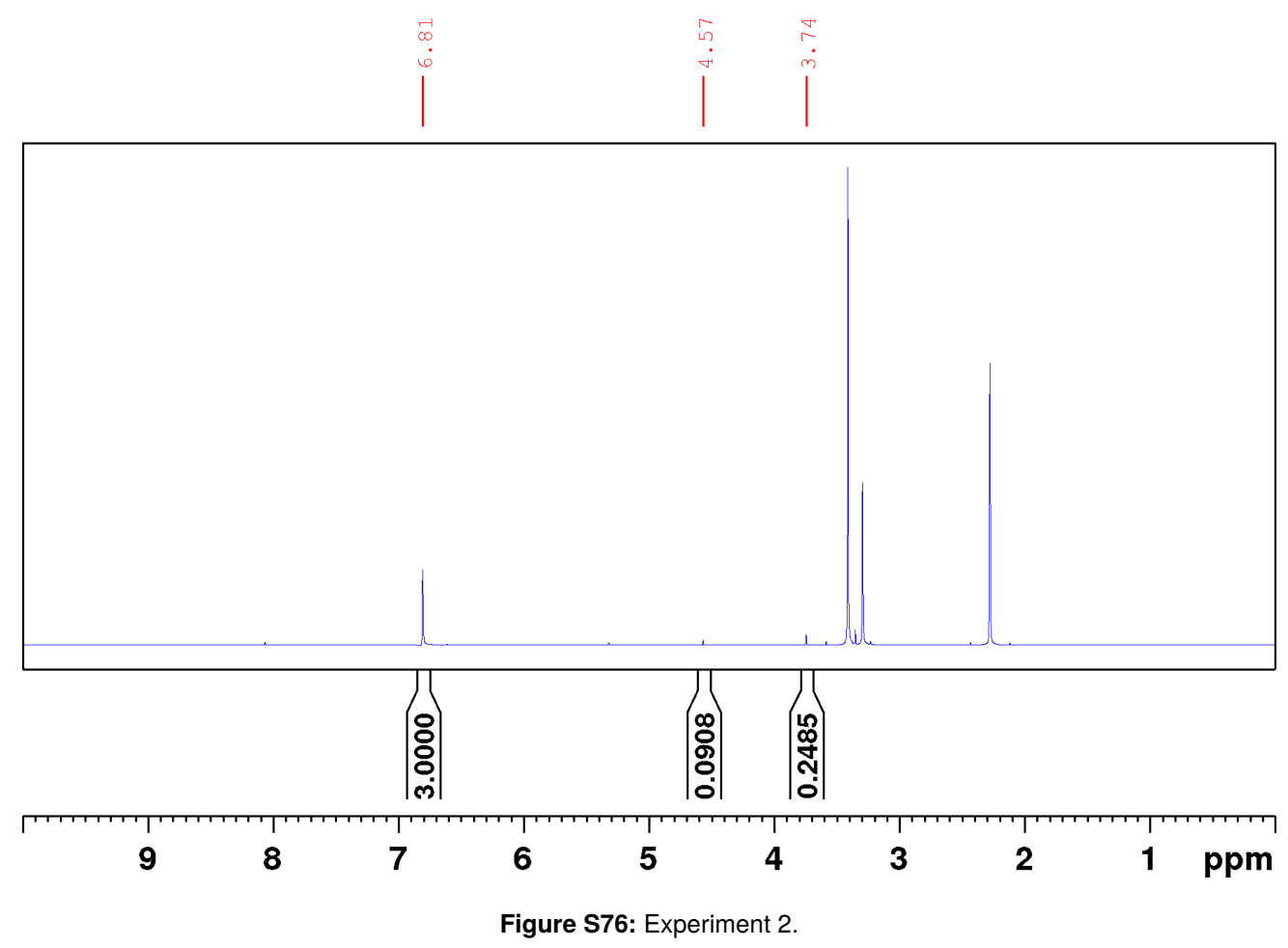


$\mathrm{CO}_{2}$ Pressure: $10 \mathrm{bar}$

$$
\begin{aligned}
\mathrm{T} & =100^{\circ} \mathrm{C} & n_{\text {cat }} & =0.375 \mu \mathrm{mol} \\
p_{\mathrm{H} 2} & =90 \mathrm{bar} & n_{\mathrm{add}} & =1.5625 \mu \mathrm{mol} \\
p_{\mathrm{CO} 2} & =10 \mathrm{bar} & \text { add } & =\mathrm{Al}(\mathrm{OTf})_{3} \\
t & =18 \mathrm{~h} & V_{\mathrm{MeOH}} & =0.5 \mathrm{~mL}
\end{aligned}
$$

Table S37: Catalyses results of catalyst $\left[\mathrm{Ru}\left(P\right.\right.$-triphos $\left.\left.{ }^{\mathrm{Ph}}\right)(\mathrm{tmm})\right] \mathbf{2 c}$ at $10 \mathrm{bar} \mathrm{CO}_{2}$ pressure.

\begin{tabular}{lccccc}
\hline & Integral $_{\mathrm{DMM}}$ & $\mathrm{TON}_{\mathrm{DMM}}$ & Integral $_{\mathrm{MF}}$ & $\mathrm{TON}_{\mathrm{MF}}$ & Ratio \\
\hline Experiment 1 & 0.1072 & 360 & 0.1622 & 363 & 0.99 \\
Experiment 2 & 0.1017 & 341 & 0.1347 & 301 & 1.13 \\
Average & - & $351(13)$ & - & $332(44)$ & $1.06(0.01)$ \\
\hline
\end{tabular}

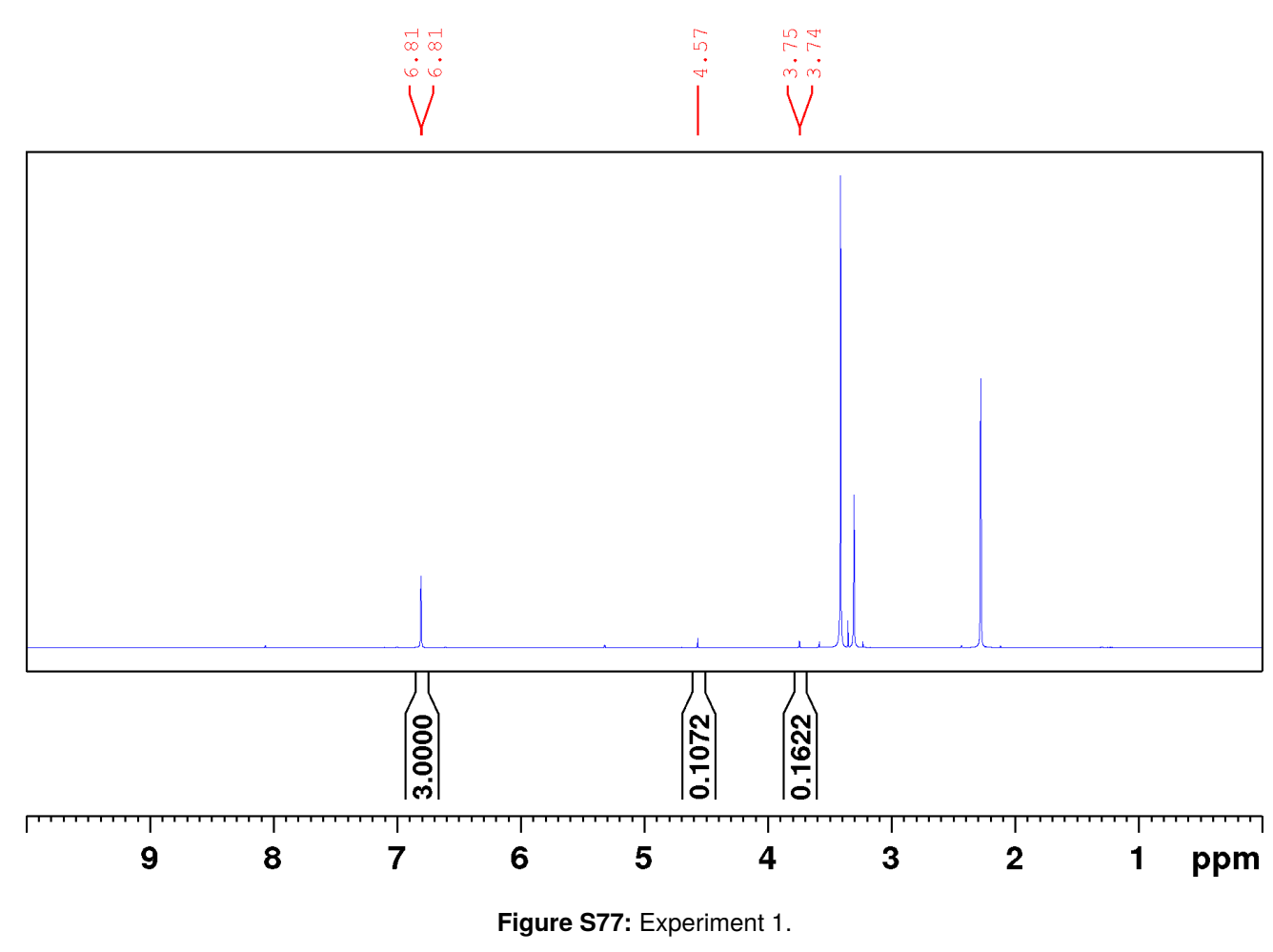




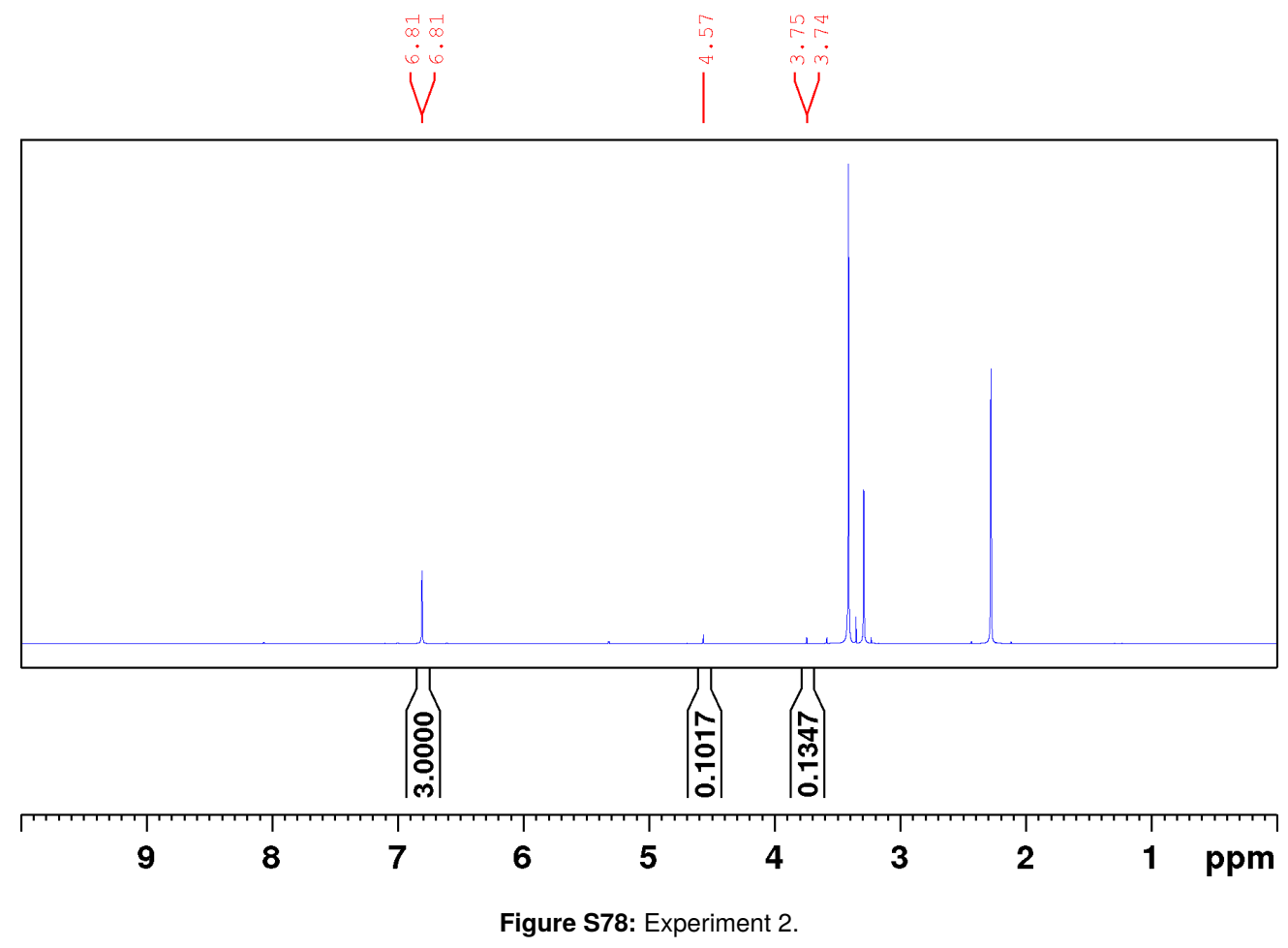


$\mathrm{CO}_{2}$ Pressure: 20 bar

$$
\begin{aligned}
\mathrm{T} & =100^{\circ} \mathrm{C} & n_{\text {cat }} & =0.375 \mu \mathrm{mol} \\
p_{\mathrm{H} 2} & =90 \mathrm{bar} & n_{\text {add }} & =1.5625 \mu \mathrm{mol} \\
p_{\mathrm{CO} 2} & =20 \mathrm{bar} & \text { add } & =\mathrm{Al}(\mathrm{OTf})_{3} \\
t & =18 \mathrm{~h} & V_{\mathrm{MeOH}} & =0.5 \mathrm{~mL}
\end{aligned}
$$

Table S38: Catalyses results of catalyst $\left[\mathrm{Ru}\left(P\right.\right.$-triphos $\left.\left.{ }^{\mathrm{Ph}}\right)(\mathrm{tmm})\right] \mathbf{2 c}$ at $20 \mathrm{bar} \mathrm{CO}_{2}$ pressure.

\begin{tabular}{lccccc}
\hline & Integral $_{\mathrm{DMM}}$ & $\mathrm{TON}_{\mathrm{DMM}}$ & Integral $_{\mathrm{MF}}$ & $\mathrm{TON}_{\mathrm{MF}}$ & Ratio \\
\hline Experiment 1 & 0.1160 & 389 & 0.2429 & 543 & 0.72 \\
Experiment 2 & 0.1066 & 358 & 0.2387 & 534 & 0.67 \\
Average & - & $374(22)$ & - & $539(6)$ & $0.69(0.03)$ \\
\hline
\end{tabular}

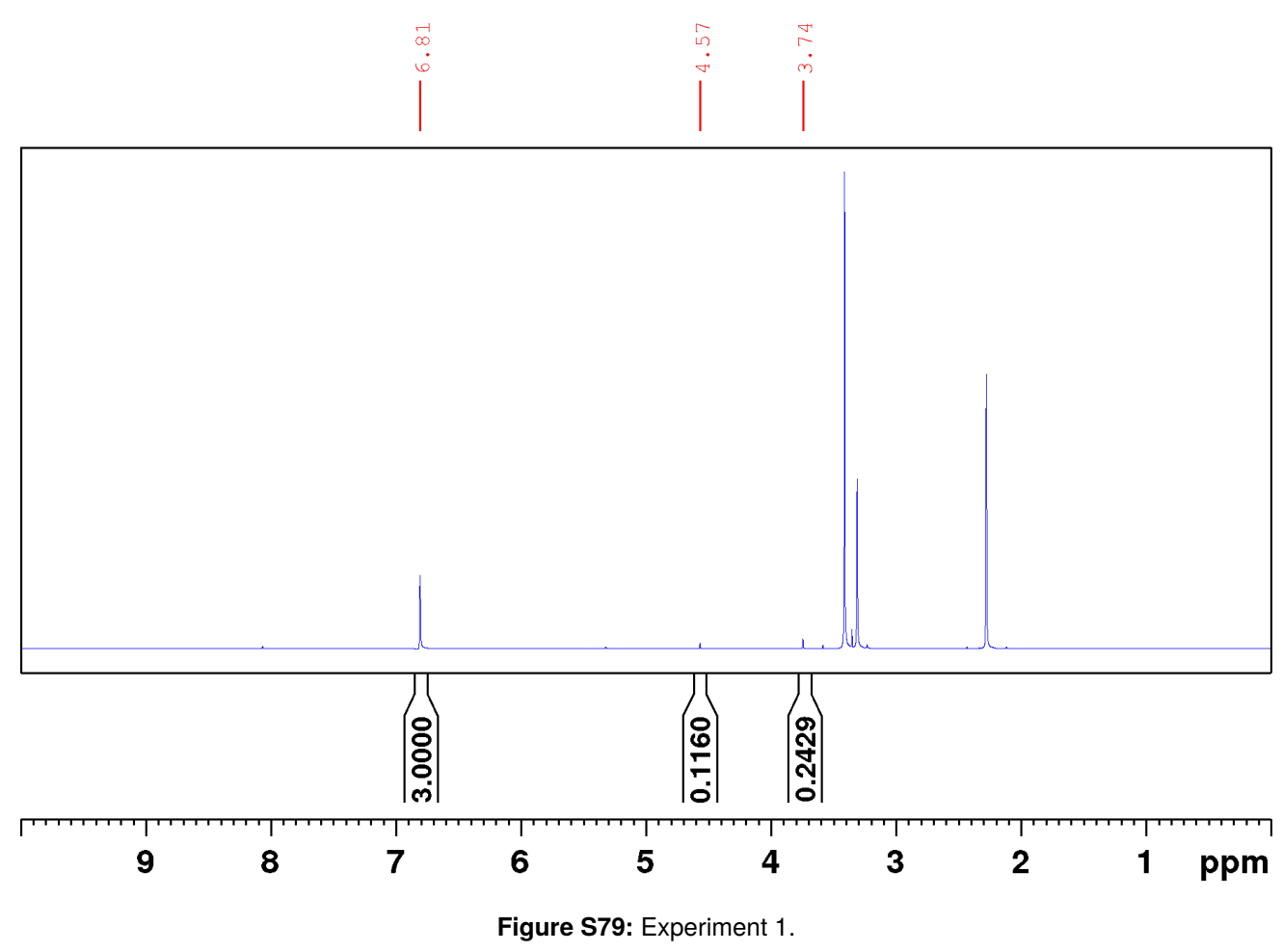




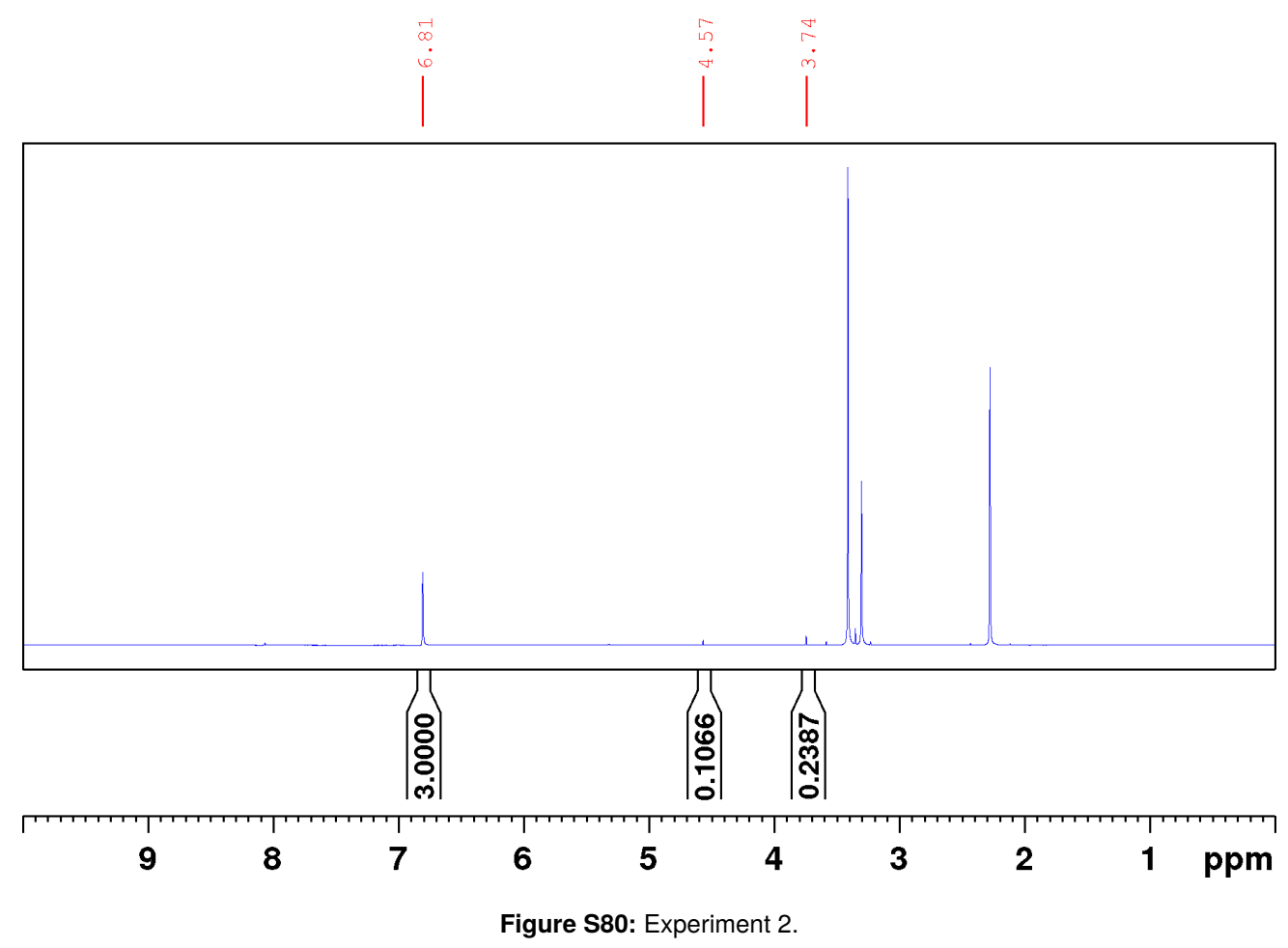


$\mathrm{CO}_{2}$ Pressure: $30 \mathrm{bar}$

$$
\begin{aligned}
\mathrm{T} & =100^{\circ} \mathrm{C} & n_{\text {cat }} & =0.375 \mu \mathrm{mol} \\
p_{\mathrm{H} 2} & =90 \mathrm{bar} & n_{\mathrm{add}} & =1.5625 \mu \mathrm{mol} \\
p_{\mathrm{CO} 2} & =30 \mathrm{bar} & \text { add } & =\mathrm{Al}(\mathrm{OTf})_{3} \\
t & =18 \mathrm{~h} & V_{\mathrm{MeOH}} & =0.5 \mathrm{~mL}
\end{aligned}
$$

Table S39: Catalyses results of catalyst $\left[\mathrm{Ru}\left(P\right.\right.$-triphos $\left.\left.{ }^{\mathrm{Ph}}\right)(\mathrm{tmm})\right] \mathbf{2 c}$ at 30 bar $\mathrm{CO}_{2}$ pressure.

\begin{tabular}{lccccc}
\hline & Integral $_{\mathrm{DMM}}$ & $\mathrm{TON}_{\mathrm{DMM}}$ & Integral $_{\mathrm{MF}}$ & $\mathrm{TON}_{\mathrm{MF}}$ & Ratio \\
\hline Experiment 1 & 0.0953 & 320 & 0.2602 & 582 & 0.55 \\
Experiment 2 & 0.0816 & 274 & 0.2362 & 528 & 0.52 \\
Average & - & $297(33)$ & - & $555(38)$ & $0.53(0.02)$ \\
\hline
\end{tabular}

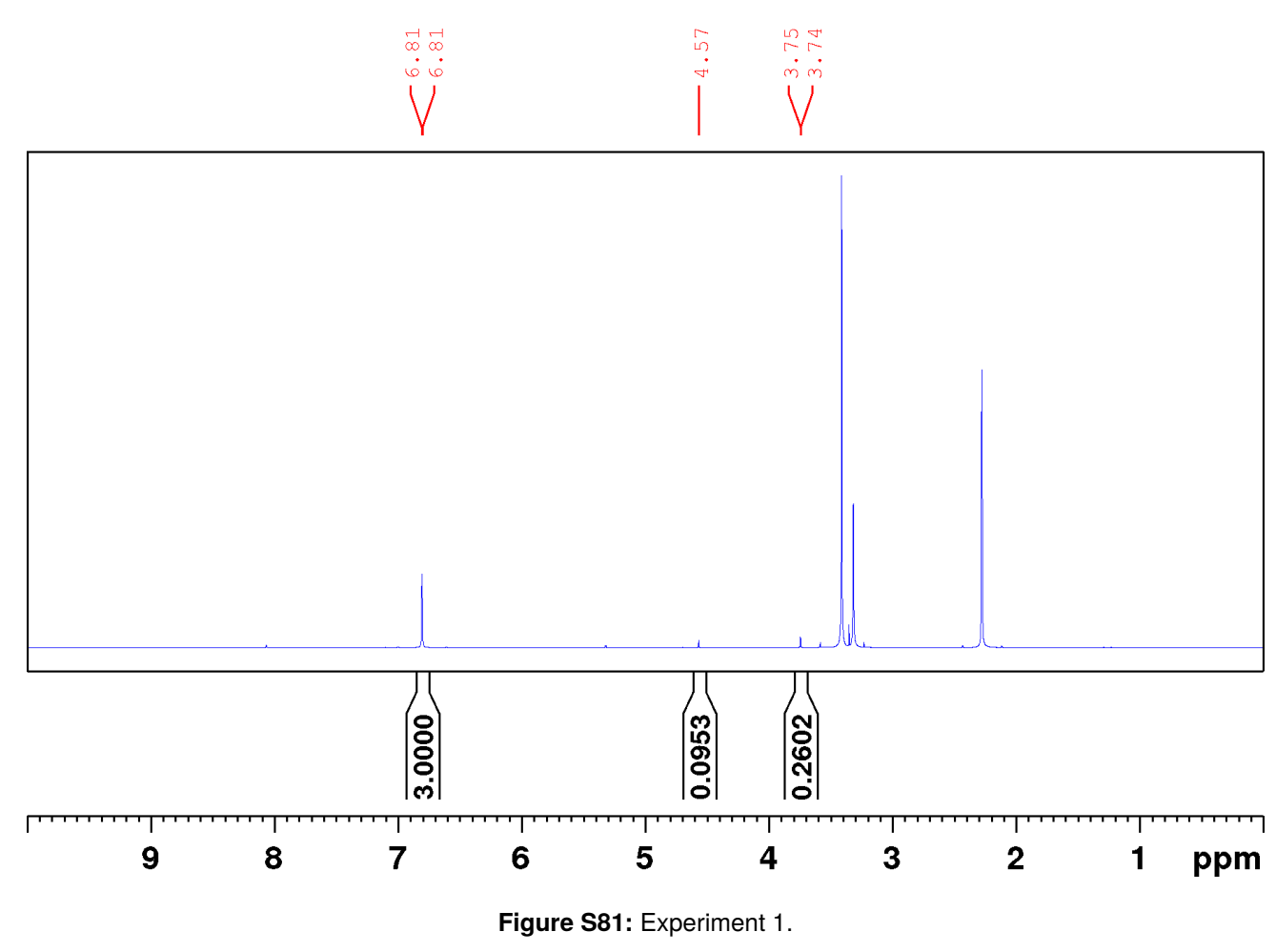




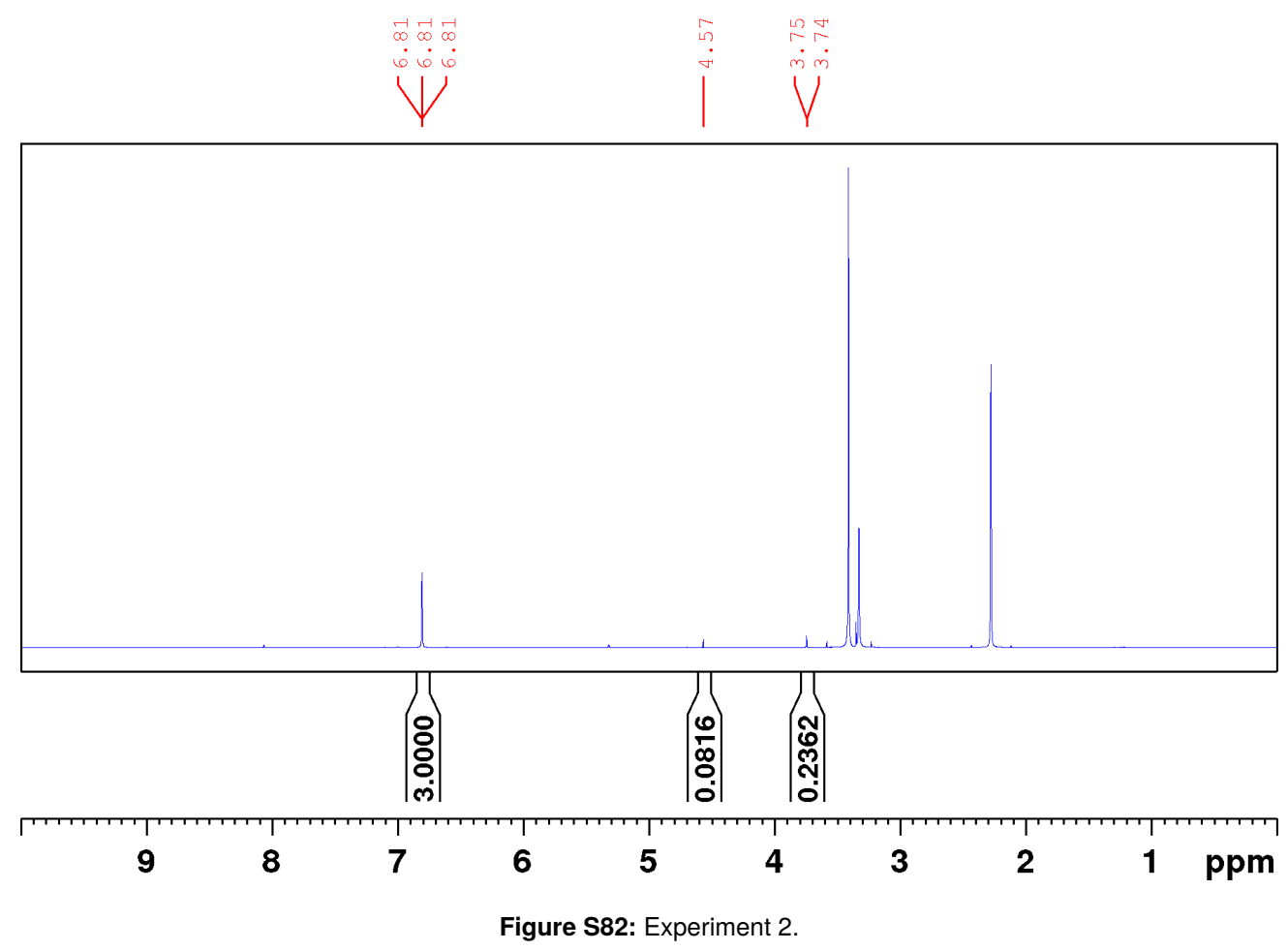




\section{Catalyst Loading: $0.1875 \mu \mathrm{mol}$}

$$
\begin{array}{rlrl}
T & =100^{\circ} \mathrm{C} & n_{\text {cat }} & =0.1875 \mu \mathrm{mol} \\
p_{\mathrm{H} 2} & =90 \mathrm{bar} & n_{\mathrm{add}} & =0.78125 \mu \mathrm{mol} \\
p_{\mathrm{CO} 2} & =20 \mathrm{bar} & \mathrm{add} & =\mathrm{Al}(\mathrm{OTf})_{3} \\
t & =18 \mathrm{~h} & V_{\mathrm{MeOH}} & =0.5 \mathrm{~mL}
\end{array}
$$

\begin{tabular}{|c|c|c|c|c|c|}
\hline & Integral $_{\mathrm{DMM}}$ & $\mathrm{TON}_{\mathrm{DMM}}$ & Integral $_{\mathrm{MF}}$ & $\mathrm{TON}_{\mathrm{MF}}$ & Ratio \\
\hline Experiment 1 & 0.0514 & 345 & 0.2991 & 1338 & 0.26 \\
\hline Experiment 2 & 0.0553 & 371 & 0.2749 & 1230 & 0.30 \\
\hline Average & - & $358(18)$ & - & $1284(76)$ & $0.28(0.03)$ \\
\hline
\end{tabular}

Table S40: Catalyses results of catalyst $\left[\mathrm{Ru}\left(P\right.\right.$-triphos $\left.\left.{ }^{\mathrm{Ph}}\right)(\mathrm{tmm})\right] 2 \mathrm{c}$ at a catalyst loading of $0.1875 \mu \mathrm{mol}$.

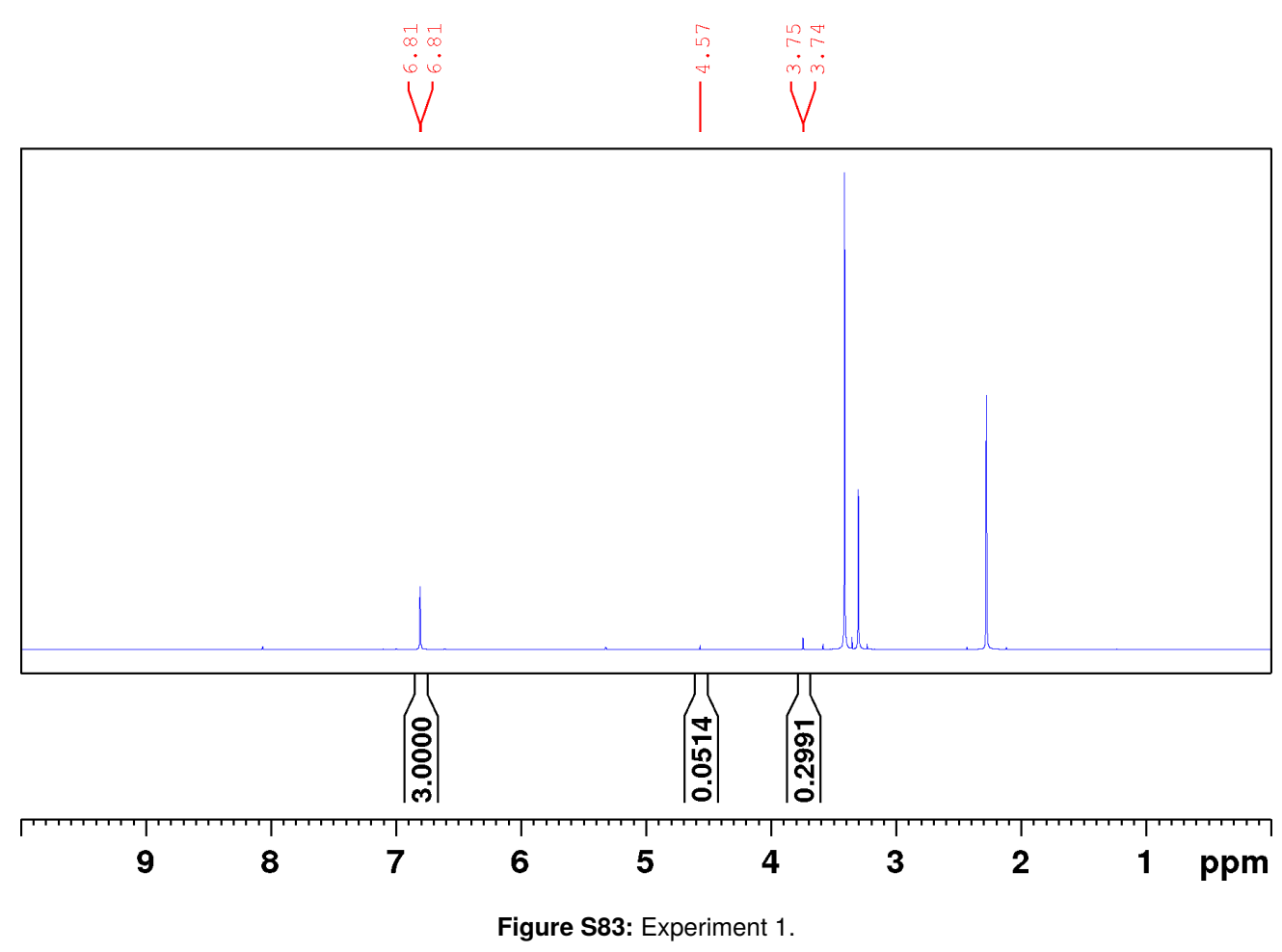




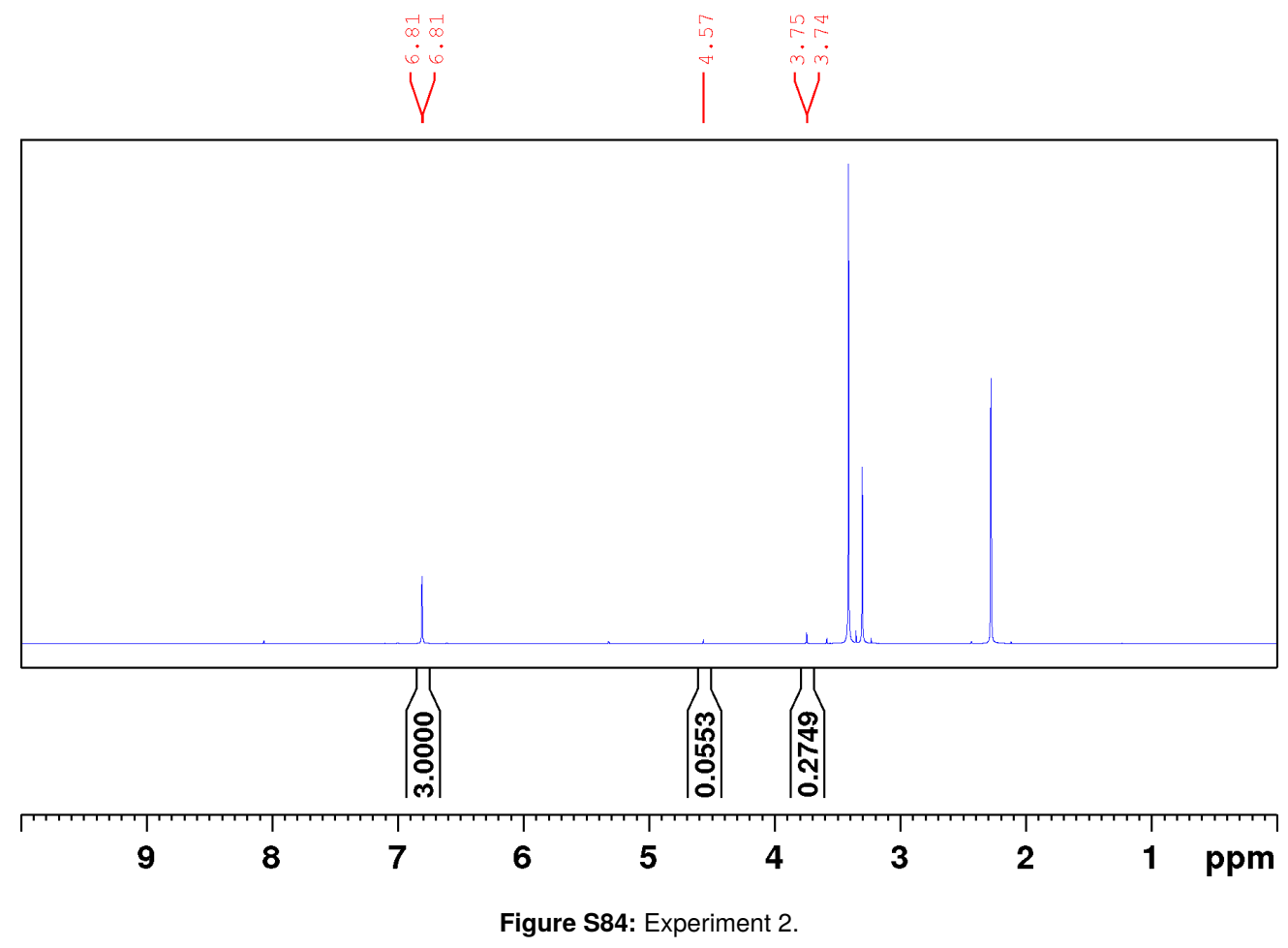




\section{Catalyst Loading: $0.375 \mu \mathrm{mol}$}

$$
\begin{array}{rlrl}
T & =100^{\circ} \mathrm{C} & n_{\mathrm{cat}} & =0.375 \mu \mathrm{mol} \\
p_{\mathrm{H} 2} & =90 \mathrm{bar} & n_{\mathrm{add}} & =1.5625 \mu \mathrm{mol} \\
p_{\mathrm{CO} 2} & =20 \mathrm{bar} & \mathrm{add} & =\mathrm{Al}(\mathrm{OTf})_{3} \\
t & =18 \mathrm{~h} & V_{\mathrm{MeOH}} & =0.5 \mathrm{~mL}
\end{array}
$$

Table S41: Catalyses results of catalyst $\left[\mathrm{Ru}\left(P\right.\right.$-triphos $\left.\left.{ }^{\mathrm{Ph}}\right)(\mathrm{tmm})\right] \mathbf{2 c}$ at a catalyst loading of $0.375 \mu \mathrm{mol}$.

\begin{tabular}{lccccc}
\hline & Integral $_{\mathrm{DMM}}$ & $\mathrm{TON}_{\mathrm{DMM}}$ & Integral $_{\mathrm{MF}}$ & $\mathrm{TON}_{\mathrm{MF}}$ & Ratio \\
\hline Experiment 1 & 0.1160 & 389 & 0.2429 & 543 & 0.72 \\
Experiment 2 & 0.1066 & 358 & 0.2387 & 534 & 0.67 \\
Average & - & $374(22)$ & - & $539(6)$ & $0.69(0.03)$ \\
\hline
\end{tabular}

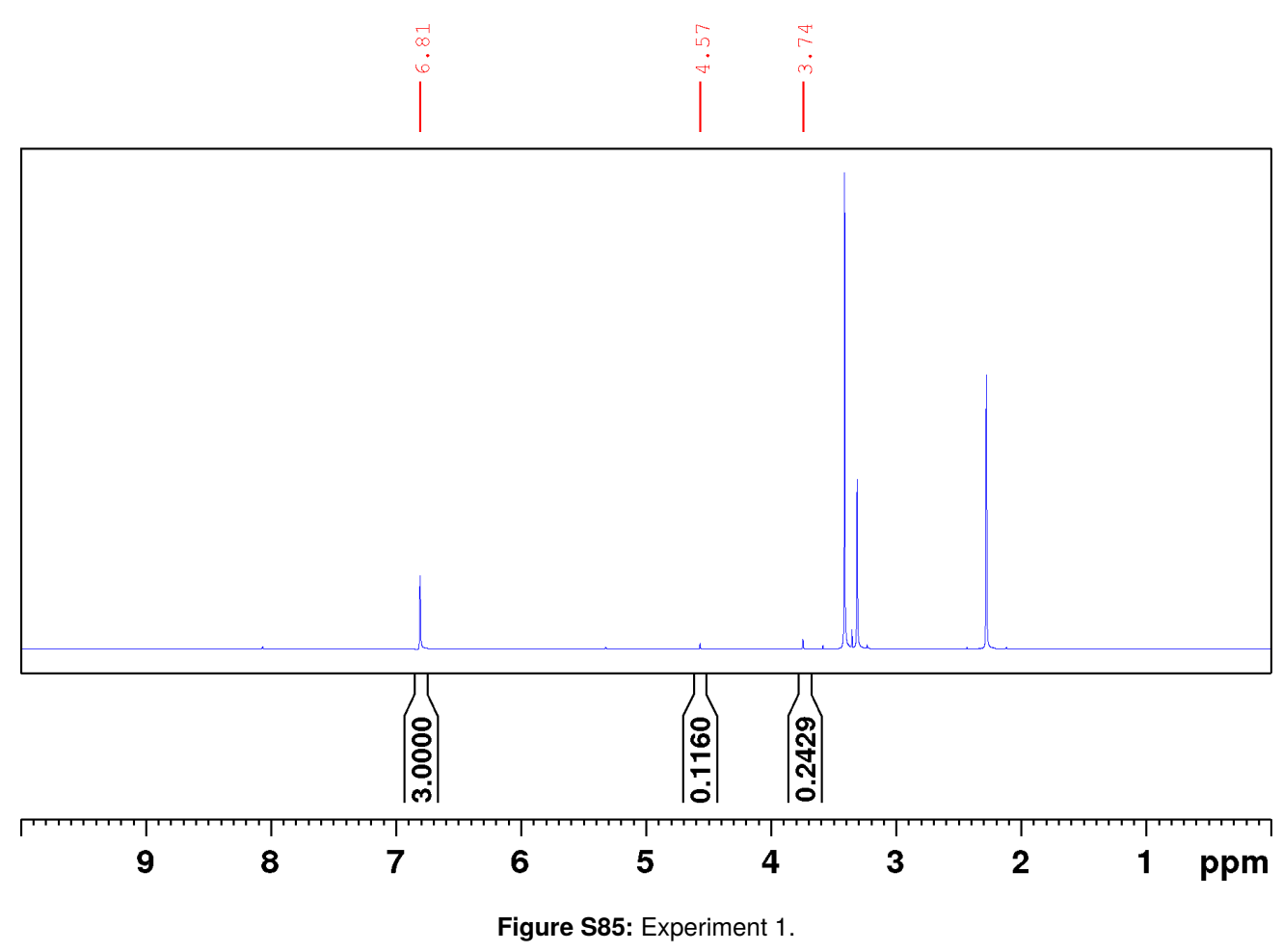




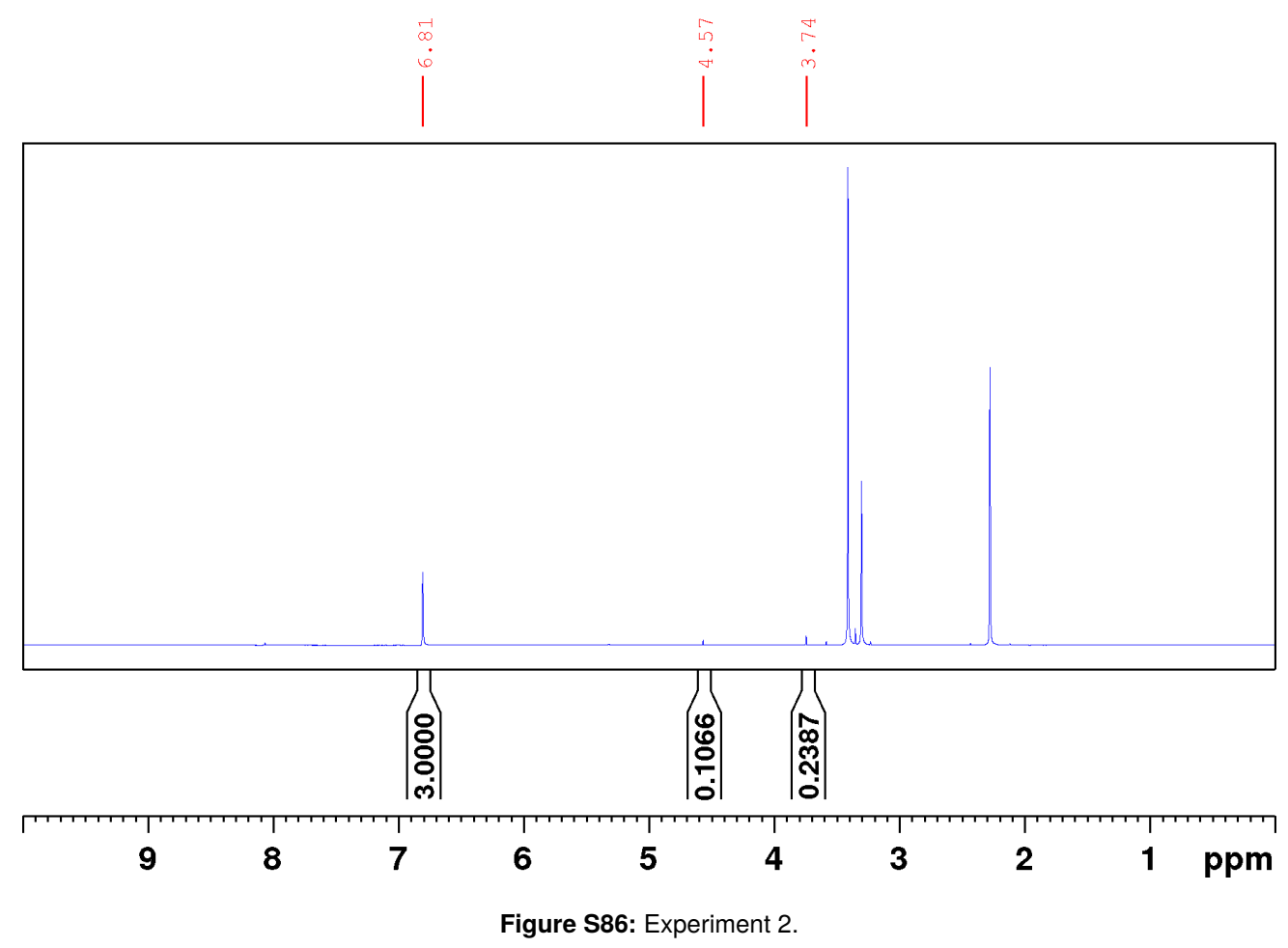


Catalyst Loading: $0.75 \mu \mathrm{mol}$

$$
\begin{aligned}
\mathrm{T} & =100^{\circ} \mathrm{C} & n_{\mathrm{cat}} & =0.75 \mu \mathrm{mol} \\
p_{\mathrm{H} 2} & =90 \mathrm{bar} & n_{\mathrm{add}} & =3.125 \mu \mathrm{mol} \\
p_{\mathrm{CO} 2} & =20 \mathrm{bar} & \text { add } & =\mathrm{Al}(\mathrm{OTf})_{3} \\
t & =18 \mathrm{~h} & V_{\mathrm{MeOH}} & =0.5 \mathrm{~mL}
\end{aligned}
$$

Table S42: Catalyses results of catalyst $\left[\mathrm{Ru}\left(P\right.\right.$-triphos $\left.\left.{ }^{\mathrm{Ph}}\right)(\mathrm{tmm})\right] 2 \mathrm{c}$ at a catalyst loading of $0.75 \mu \mathrm{mol}$.

\begin{tabular}{lccccc}
\hline & Integral $_{\mathrm{DMM}}$ & $\mathrm{TON}_{\mathrm{DMM}}$ & Integral $_{\mathrm{MF}}$ & $\mathrm{TON}_{\mathrm{MF}}$ & Ratio \\
\hline Experiment 1 & 0.1775 & 298 & 0.1857 & 208 & 1.43 \\
Experiment 2 & 0.1906 & 320 & 0.1924 & 215 & 1.49 \\
Average & - & $309(16)$ & - & $212(5)$ & $1.46(0.04)$ \\
\hline
\end{tabular}

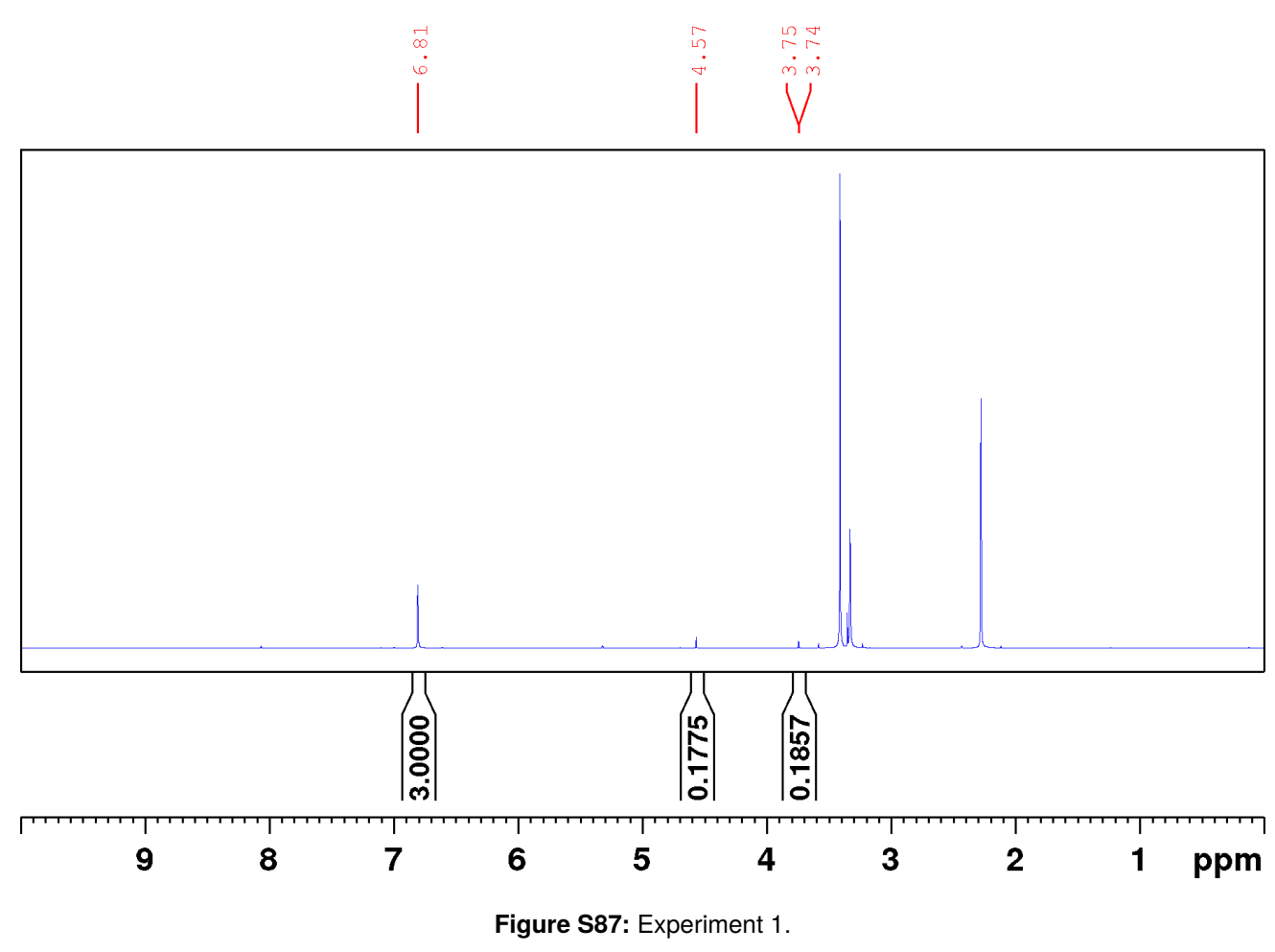




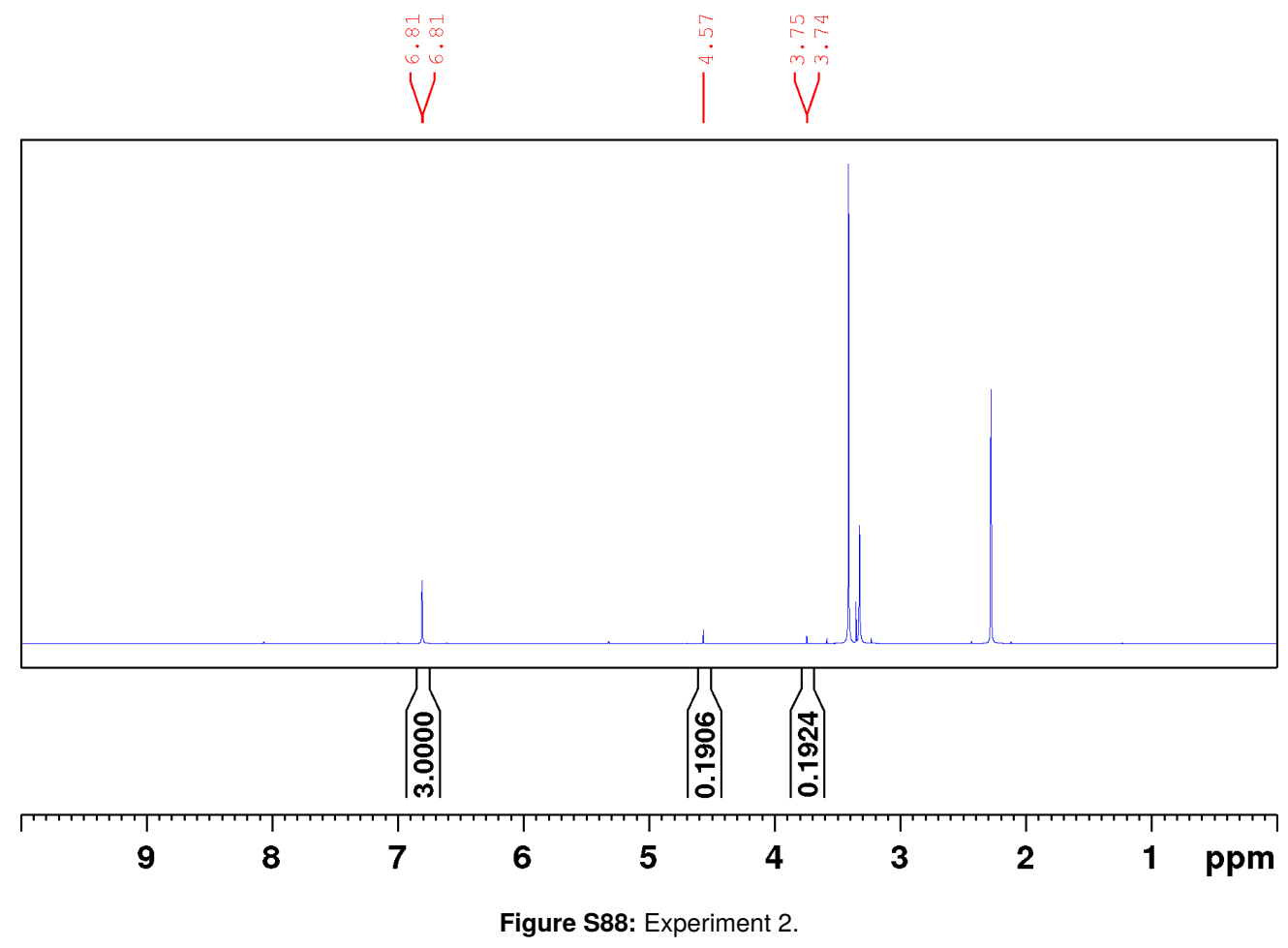




\section{Additive Loading: $0.78125 \mu \mathrm{mol}$}

$$
\begin{aligned}
T & =100^{\circ} \mathrm{C} & n_{\text {cat }} & =0.375 \mu \mathrm{mol} \\
p_{\mathrm{H} 2} & =90 \mathrm{bar} & n_{\mathrm{add}} & =0.78125 \mu \mathrm{mol} \\
p_{\mathrm{CO} 2} & =20 \mathrm{bar} & \text { add } & =\mathrm{Al}(\mathrm{OTf})_{3} \\
t & =18 \mathrm{~h} & V_{\mathrm{MeOH}} & =0.5 \mathrm{~mL}
\end{aligned}
$$

Table S43: Catalyses results of catalyst $\left[\mathrm{Ru}\left(P\right.\right.$-triphos $\left.\left.{ }^{\mathrm{Ph}}\right)(\mathrm{tmm})\right] \mathbf{2 c}$ at an additive loading of $0.78125 \mu \mathrm{mol}$.

\begin{tabular}{lccccc}
\hline & Integral $_{\mathrm{DMM}}$ & $\mathrm{TON}_{\mathrm{DMM}}$ & Integral $_{\mathrm{MF}}$ & $\mathrm{TON}_{\mathrm{MF}}$ & Ratio \\
\hline Experiment 1 & 0.0646 & 217 & 0.2462 & 551 & 0.39 \\
Experiment 2 & 0.0691 & 232 & 0.2927 & 655 & 0.35 \\
Average & - & $225(11)$ & - & $603(74)$ & $0.37(0.03)$ \\
\hline
\end{tabular}

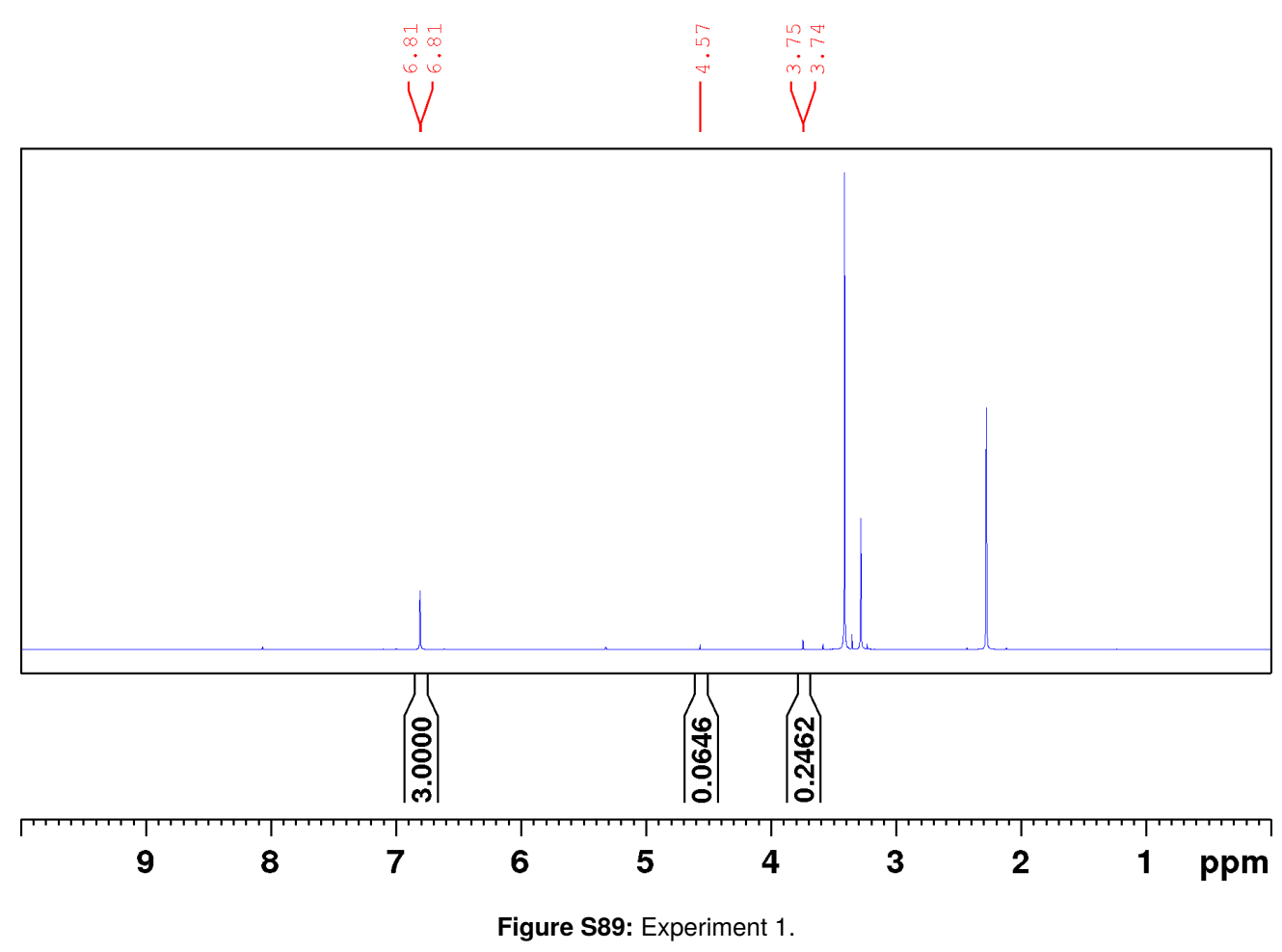




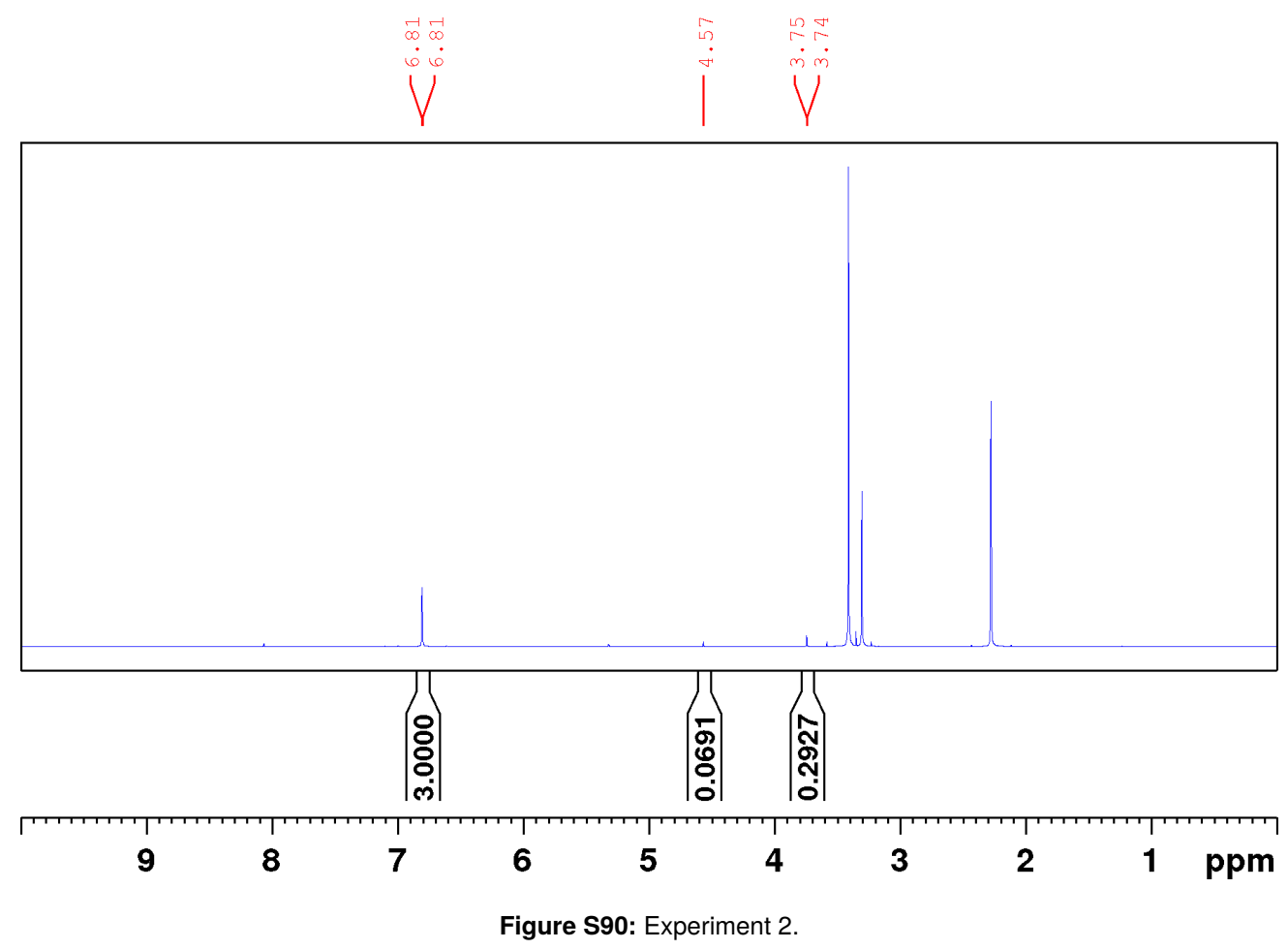




\section{Additive Loading: $1.5625 \mu \mathrm{mol}$}

$$
\begin{array}{rlrl}
T & =100{ }^{\circ} \mathrm{C} & n_{\text {cat }} & =0.375 \mu \mathrm{mol} \\
p_{\mathrm{H} 2} & =90 \mathrm{bar} & n_{\mathrm{add}} & =1.5625 \mu \mathrm{mol} \\
p_{\mathrm{CO} 2} & =20 \mathrm{bar} & \mathrm{add} & =\mathrm{Al}(\mathrm{OTf})_{3} \\
t & =18 \mathrm{~h} & V_{\mathrm{MeOH}} & =0.5 \mathrm{~mL}
\end{array}
$$

Table S44: Catalyses results of catalyst $\left[\mathrm{Ru}\left(P\right.\right.$-triphos $\left.\left.{ }^{\mathrm{Ph}}\right)(\mathrm{tmm})\right] 2 \mathrm{c}$ at an additive loading of $1.5625 \mu \mathrm{mol}$.

\begin{tabular}{lccccc}
\hline & Integral $_{\mathrm{DMM}}$ & $\mathrm{TON}_{\mathrm{DMM}}$ & Integral $_{\mathrm{MF}}$ & $\mathrm{TON}_{\mathrm{MF}}$ & Ratio \\
\hline Experiment 1 & 0.1160 & 389 & 0.2429 & 543 & 0.72 \\
Experiment 2 & 0.1066 & 358 & 0.2387 & 534 & 0.67 \\
Average & - & $374(22)$ & - & $539(6)$ & $0.69(0.03)$ \\
\hline
\end{tabular}

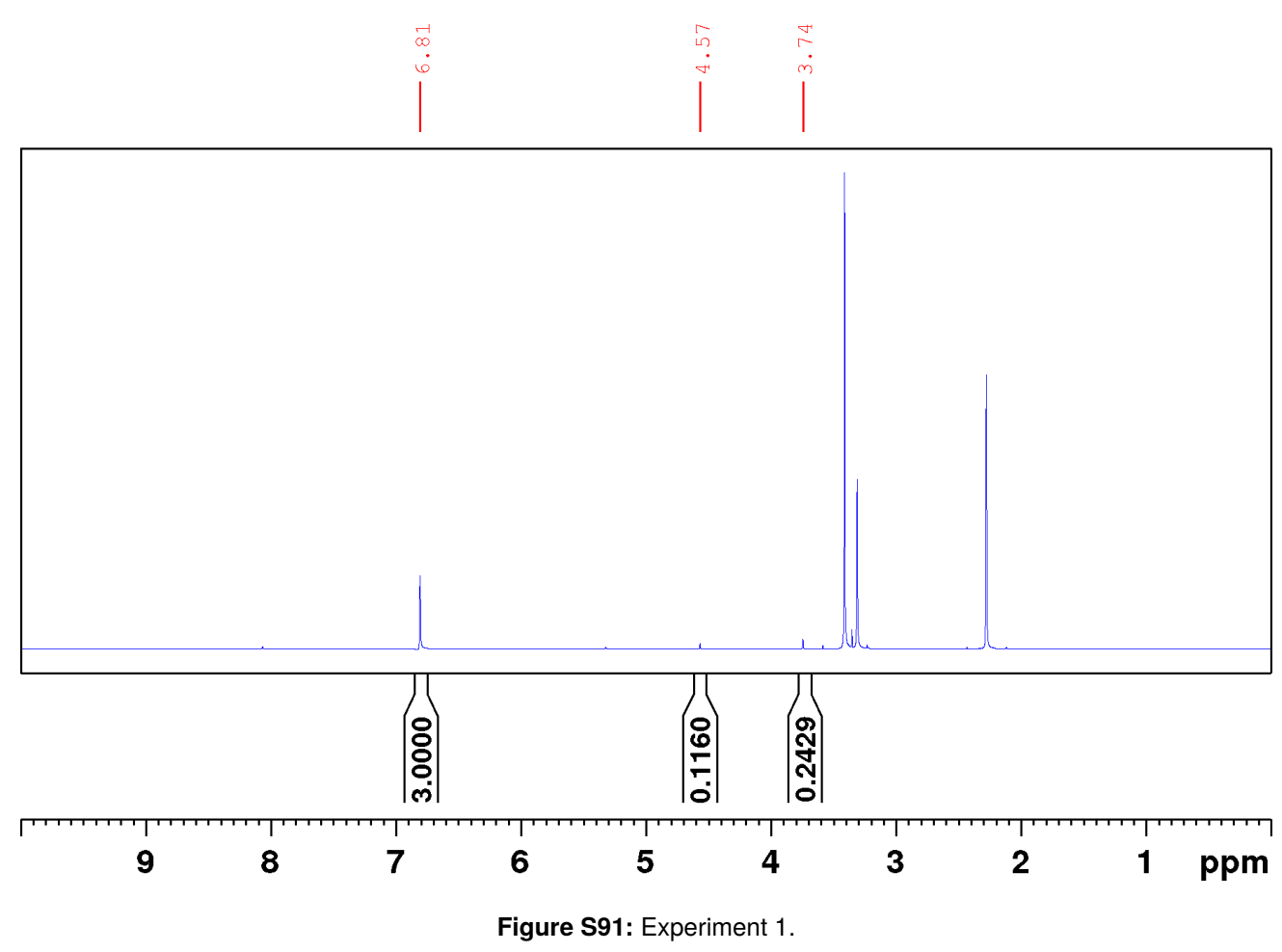




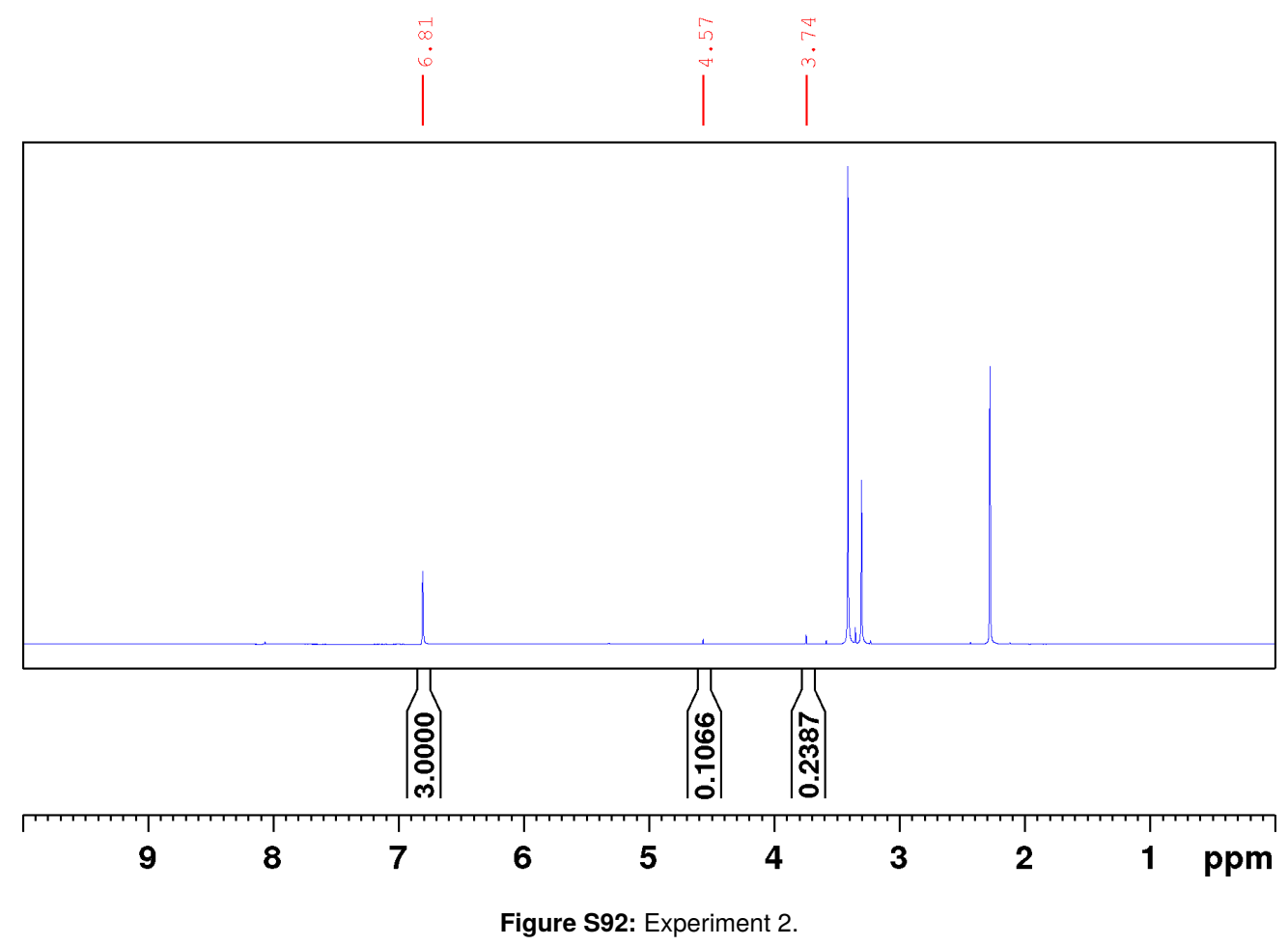




\section{Additive Loading: $3.125 \mu \mathrm{mol}$}

$$
\begin{aligned}
\mathrm{T} & =100{ }^{\circ} \mathrm{C} & n_{\mathrm{cat}} & =0.375 \mu \mathrm{mol} \\
p_{\mathrm{H} 2} & =90 \mathrm{bar} & n_{\mathrm{add}} & =3.125 \mu \mathrm{mol} \\
p_{\mathrm{CO} 2} & =20 \mathrm{bar} & \text { add } & =\mathrm{Al}(\mathrm{OTf})_{3} \\
t & =18 \mathrm{~h} & V_{\mathrm{MeOH}} & =0.5 \mathrm{~mL}
\end{aligned}
$$

Table S45: Catalyses results of catalyst $\left[\mathrm{Ru}\left(P\right.\right.$-triphos $\left.\left.{ }^{\mathrm{Ph}}\right)(\mathrm{tmm})\right] 2 \mathrm{c}$ at an additive loading of $3.125 \mu \mathrm{mol}$.

\begin{tabular}{lccccc}
\hline & Integral $_{\mathrm{DMM}}$ & TON $_{\mathrm{DMM}}$ & Integral $_{\mathrm{MF}}$ & $\mathrm{TON}_{\mathrm{MF}}$ & Ratio \\
\hline Experiment 1 & 0.1297 & 435 & 0.2463 & 551 & 0.79 \\
Experiment 2 & 0.1321 & 443 & 0.2144 & 479 & 0.92 \\
Average & - & $439(6)$ & - & $515(51)$ & $0.86(0.09)$ \\
\hline
\end{tabular}

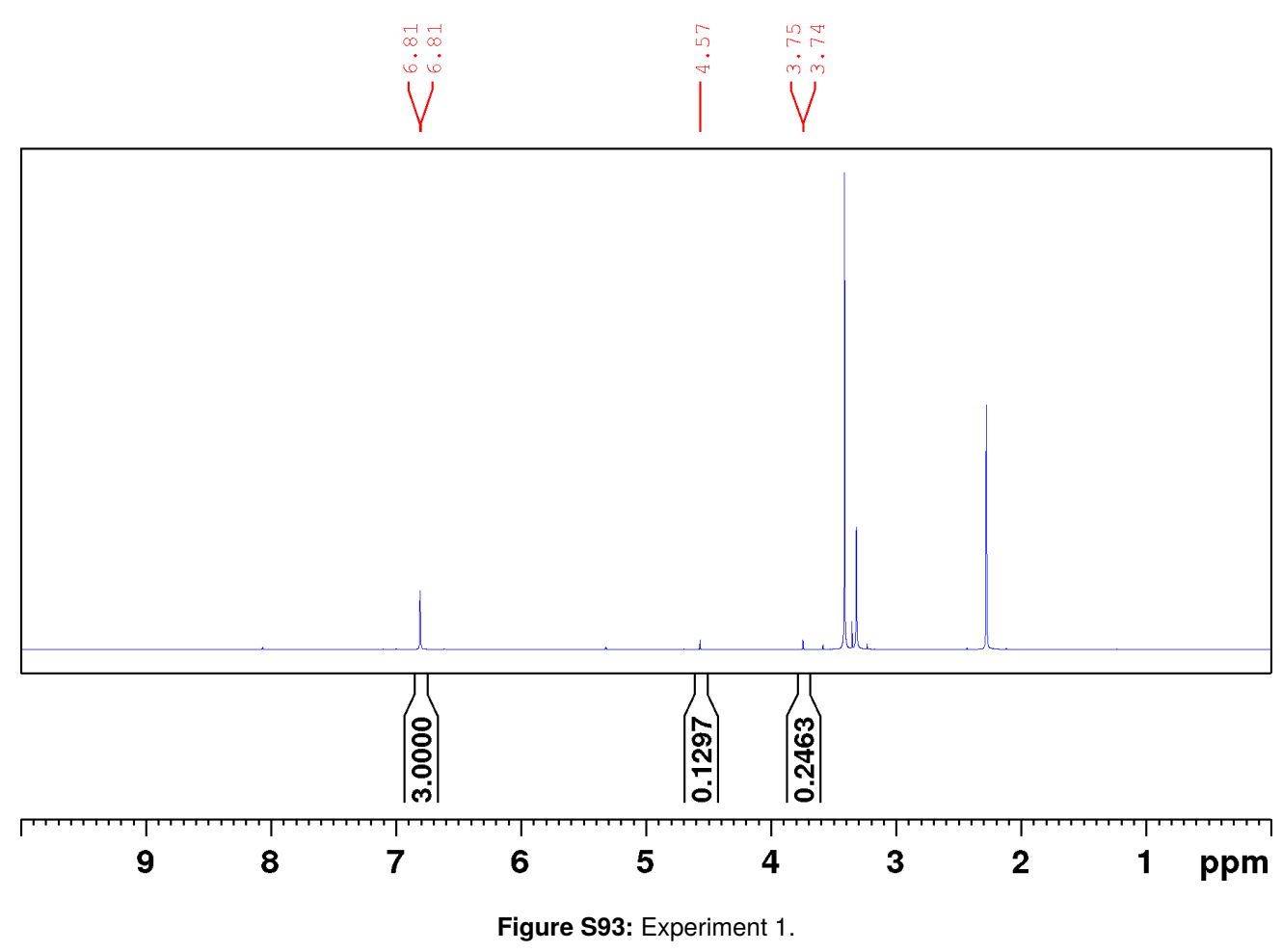




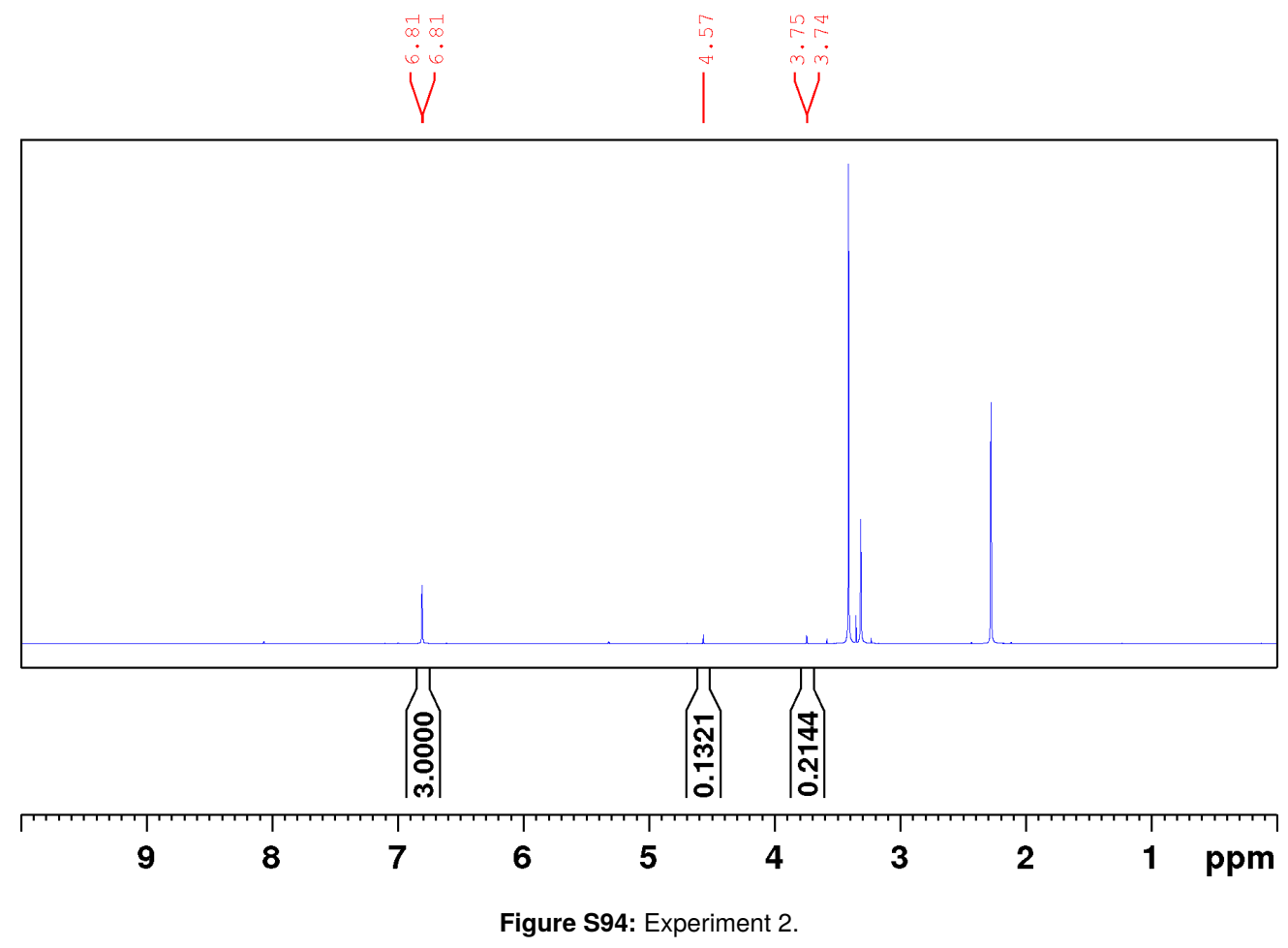




\subsection{4 [Ru(triphos $\left.\left.{ }^{\mathrm{Ph}}\right)(\mathrm{tmm})\right] \mathrm{Sl}-4$}

$$
\begin{aligned}
\mathrm{T} & =90^{\circ} \mathrm{C} & n_{\mathrm{cat}} & =0.375 \mu \mathrm{mol} \\
p_{\mathrm{H} 2} & =90 \mathrm{bar} & n_{\mathrm{add}} & =3.125 \mu \mathrm{mol} \\
p_{\mathrm{CO} 2} & =20 \mathrm{bar} & \text { add } & =\mathrm{Al}(\mathrm{OTf})_{3} \\
t & =18 \mathrm{~h} & V_{\mathrm{MeOH}} & =0.5 \mathrm{~mL}
\end{aligned}
$$

Table S46: Catalyses results of catalyst $\left[\mathrm{Ru}\left(\operatorname{triphos}^{\mathrm{Ph}}\right)(\mathrm{tmm})\right]$ SI-4

\begin{tabular}{lccccc}
\hline & Integral $_{\mathrm{DMM}}$ & $\mathrm{TON}_{\mathrm{DMM}}$ & Integral $_{\mathrm{MF}}$ & $\mathrm{TON}_{\mathrm{MF}}$ & Ratio \\
\hline Experiment 1 & 0.2075 & 696 & 0.1686 & 377 & 1.85 \\
Experiment 2 & 0.1845 & 619 & 0.1378 & 308 & 2.01 \\
Average & - & $658(54)$ & - & $343(49)$ & $1.93(0.11)$ \\
\hline
\end{tabular}






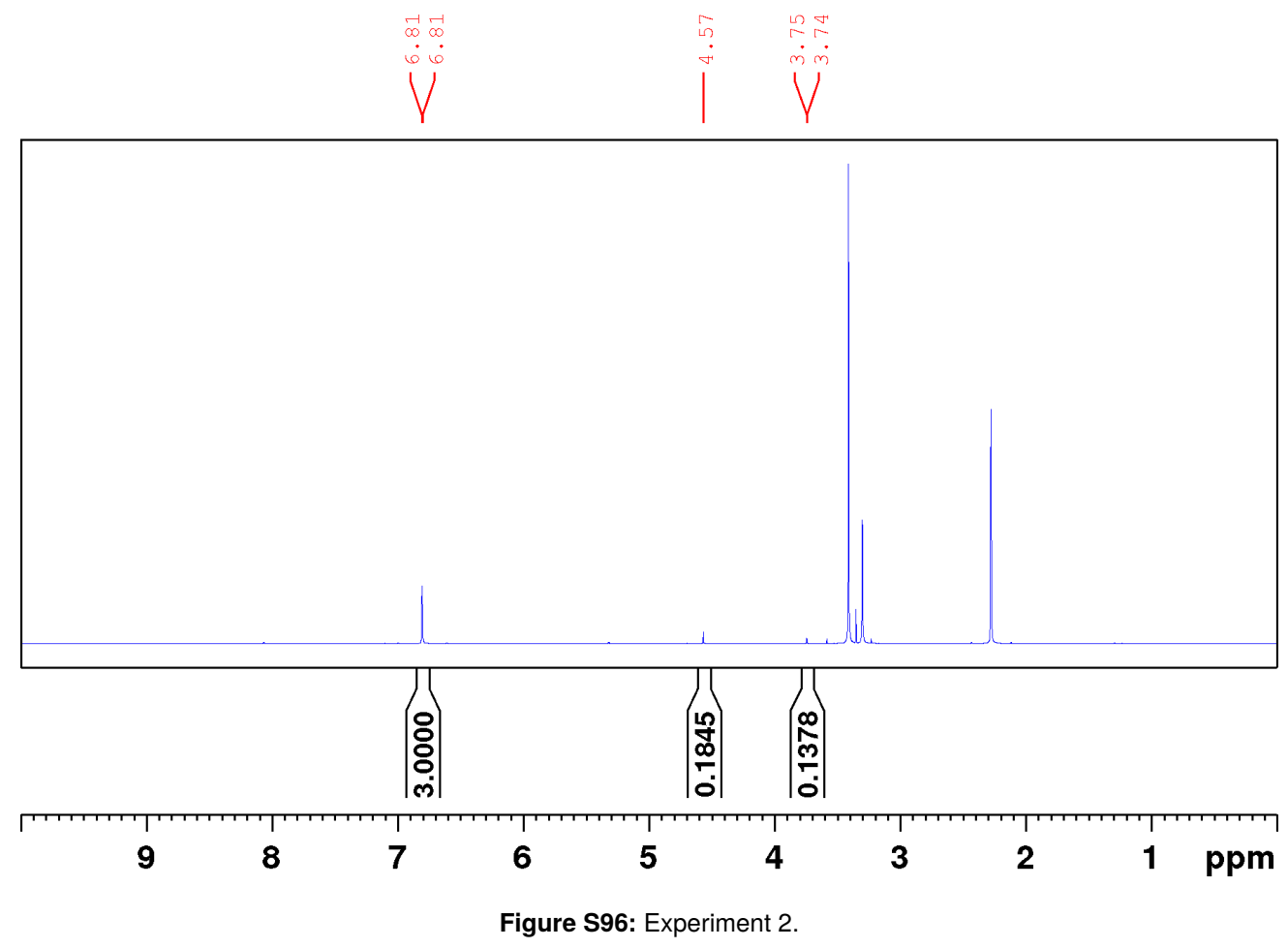




\subsection{Background Measurements}

\subsubsection{Run without Catalyst and Co-Catalyst}

$$
\begin{aligned}
\mathrm{T} & =90{ }^{\circ} \mathrm{C} & n_{\mathrm{cat}} & =0.00 \mu \mathrm{mol} \\
p_{\mathrm{H} 2} & =90 \mathrm{bar} & n_{\mathrm{add}} & =0.00 \mu \mathrm{mol} \\
p_{\mathrm{CO} 2} & =20 \mathrm{bar} & \text { add } & =\text { none } \\
t & =18 \mathrm{~h} & V_{\mathrm{MeOH}} & =0.5 \mathrm{~mL}
\end{aligned}
$$

Table S47: Run without catalyst and co-catalyst.

\begin{tabular}{lccccc}
\hline & Integral $_{\mathrm{DMM}}$ & TON $_{\mathrm{DMM}}$ & Integral $_{\mathrm{MF}}$ & $\mathrm{TON}_{\mathrm{MF}}$ & Ratio \\
\hline Experiment 1 & 0.0001 & 0 & 0.0051 & 6 & 0.03 \\
Experiment 2 & 0.0003 & 1 & 0.0022 & 2 & 0.20 \\
Average & - & $0(0)$ & - & $4(2)$ & $0.12(0.12)$ \\
\hline
\end{tabular}

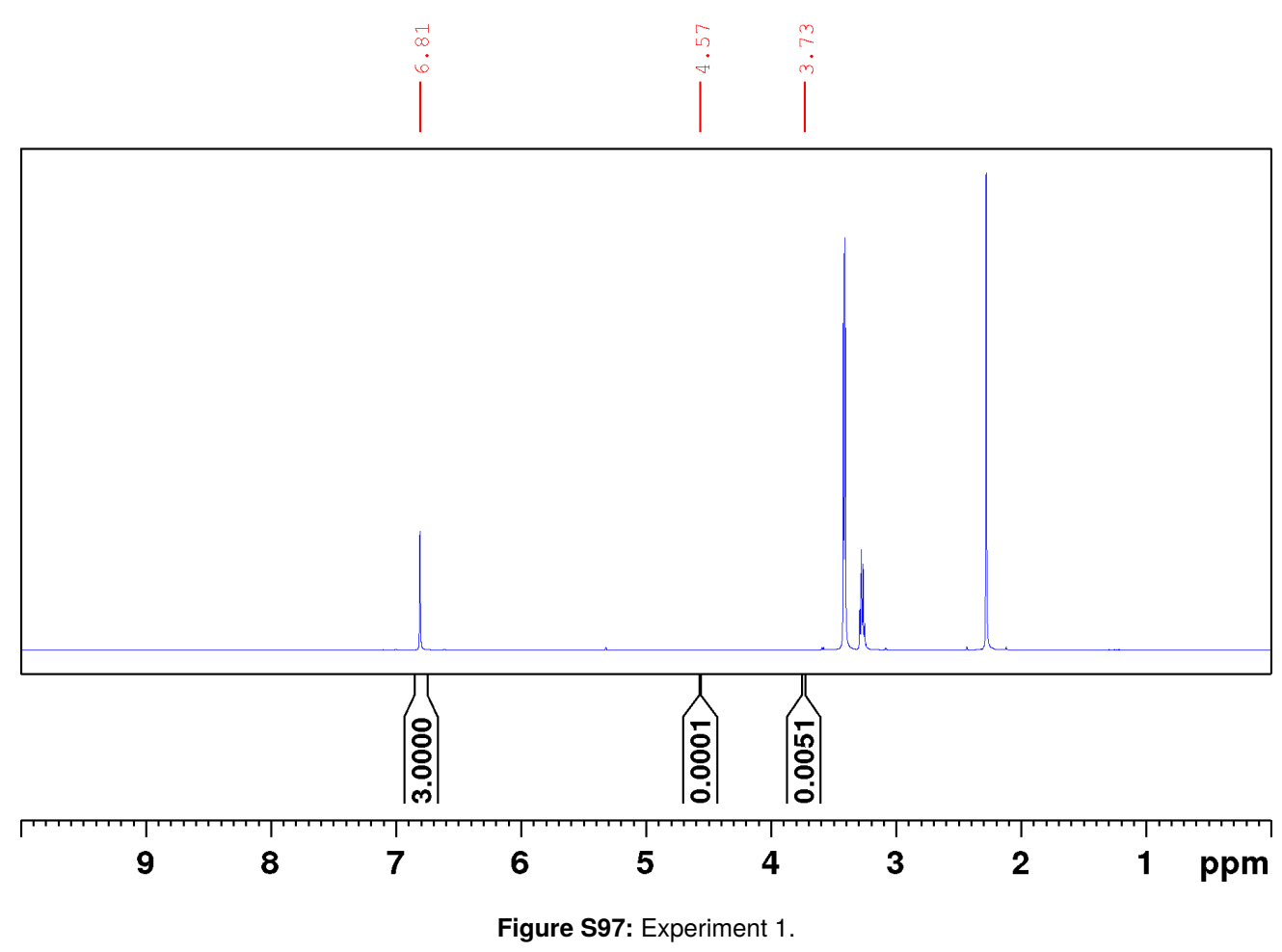




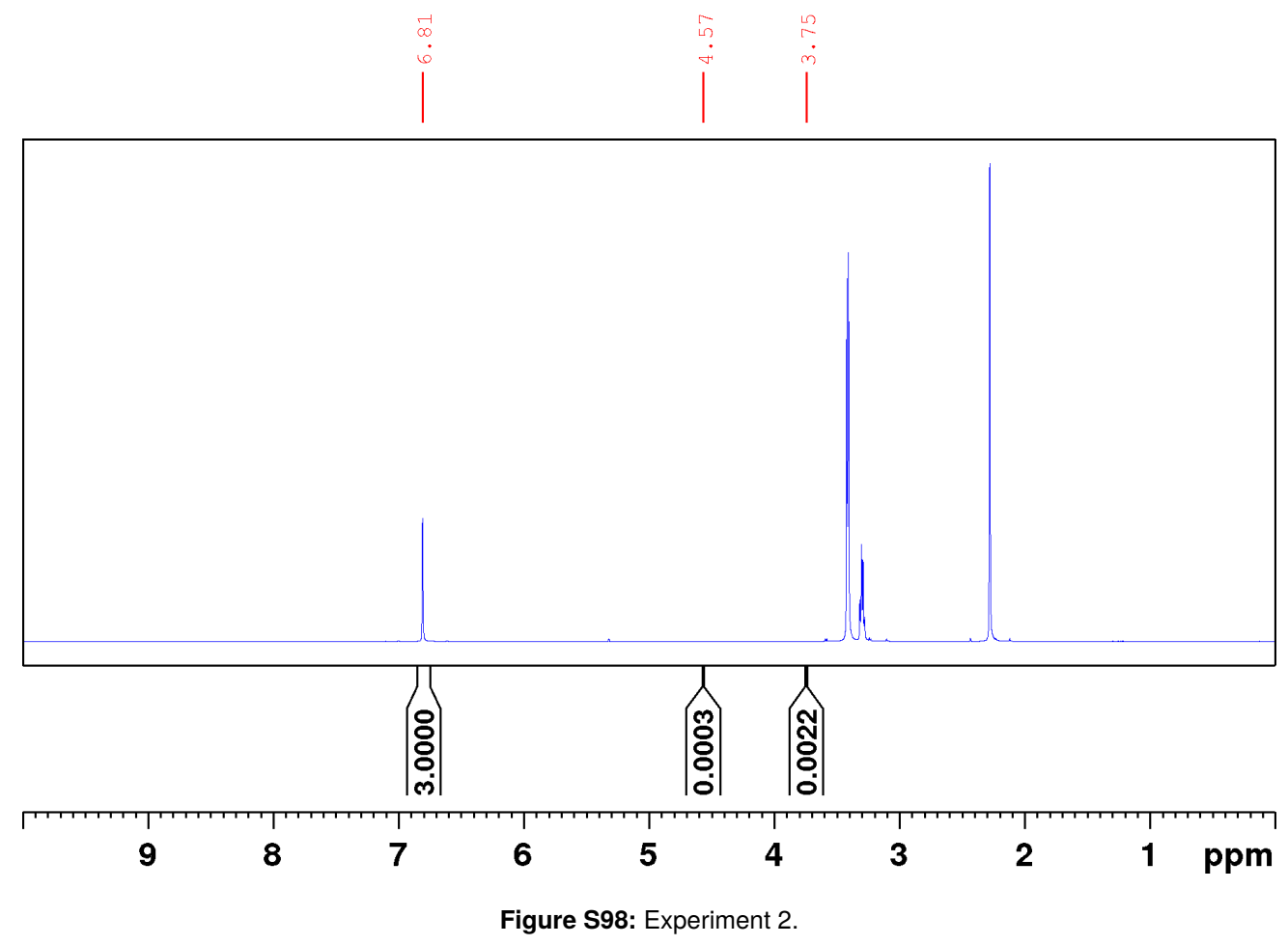




\subsubsection{Run with $\left[\mathrm{Ru}\left({ }^{\mathrm{Ph}} \mathrm{Si}\right.\right.$-triphos $\left.\left.{ }^{\mathrm{Ph}}\right)(\mathrm{tmm})\right] 2 \mathrm{2a}$ and without Co-Catalyst}

$$
\begin{aligned}
T & =90{ }^{\circ} \mathrm{C} & n_{\text {cat }} & =0.375 \mu \mathrm{mol} \\
p_{\mathrm{H} 2} & =90 \mathrm{bar} & n_{\mathrm{add}} & =0.00 \mu \mathrm{mol} \\
p_{\mathrm{CO} 2} & =20 \mathrm{bar} & \text { add } & =\text { none } \\
t & =18 \mathrm{~h} & V_{\mathrm{MeOH}} & =0.5 \mathrm{~mL}
\end{aligned}
$$

Table S48: Run with $\left[\mathrm{Ru}\left({ }^{\mathrm{Ph}} \mathrm{Si}\right.\right.$-triphos $\left.\left.{ }^{\mathrm{Ph}}\right)(\mathrm{tmm})\right]$ 2a and without Co-Catalyst.

\begin{tabular}{lccccc}
\hline & Integral $_{\mathrm{DMM}}$ & $\mathrm{TON}_{\mathrm{DMM}}$ & Integral $_{\mathrm{MF}}$ & $\mathrm{TON}_{\mathrm{MF}}$ & Ratio \\
\hline Experiment 1 & 0.0000 & 0 & 0.0077 & 17 & 0.00 \\
Experiment 2 & 0.0008 & 3 & 0.0085 & 19 & 0.14 \\
Average & - & $2(2)$ & - & $18(1)$ & $0.07(0.10)$ \\
\hline
\end{tabular}

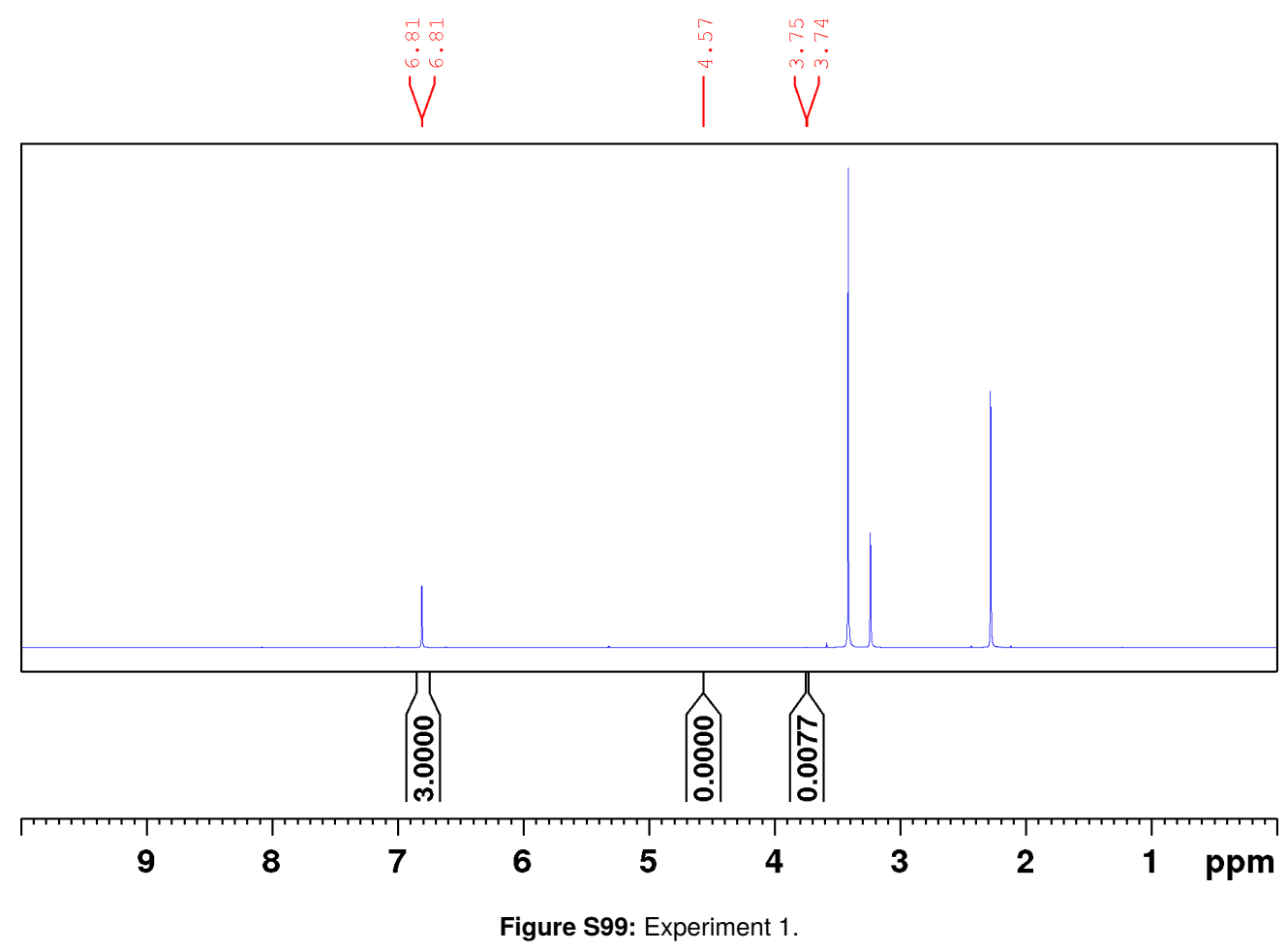




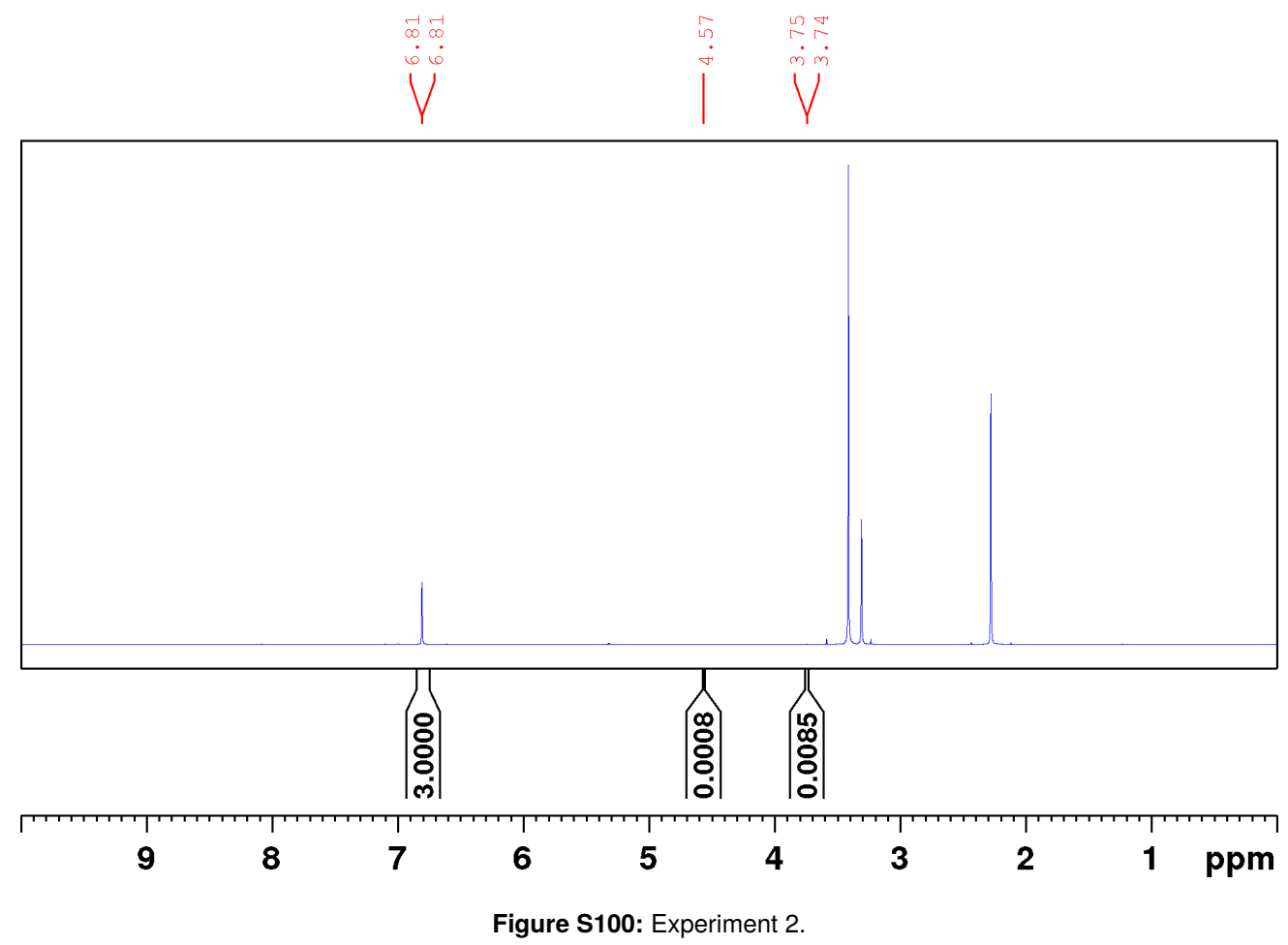




\subsubsection{Run with [Ru( ${ }^{\mathrm{Me}} \mathrm{Si}$-triphos $\left.\left.{ }^{\mathrm{Ph}}\right)(\mathrm{tmm})\right] 2 \mathrm{2b}$ and without Co-Catalyst}

$$
\begin{aligned}
T & =90{ }^{\circ} \mathrm{C} & n_{\text {cat }} & =0.375 \mu \mathrm{mol} \\
p_{\mathrm{H} 2} & =90 \mathrm{bar} & n_{\text {add }} & =0.00 \mu \mathrm{mol} \\
p_{\mathrm{CO} 2} & =20 \mathrm{bar} & \text { add } & =\text { none } \\
t & =18 \mathrm{~h} & V_{\mathrm{MeOH}} & =0.5 \mathrm{~mL}
\end{aligned}
$$

Table S49: Run with $\left[\mathrm{Ru}\left({ }^{\mathrm{Me}} \mathrm{Si}\right.\right.$-triphos $\left.\left.{ }^{\mathrm{Ph}}\right)(\mathrm{tmm})\right] \mathbf{2 b}$ and without Co-Catalyst.

\begin{tabular}{lccccc}
\hline & Integral $_{\mathrm{DMM}}$ & $\mathrm{TON}_{\mathrm{DMM}}$ & Integral $_{\mathrm{MF}}$ & $\mathrm{TON}_{\mathrm{MF}}$ & Ratio \\
\hline Experiment 1 & 0.0001 & 0 & 0.0088 & 20 & 0.00 \\
Experiment 2 & 0.0000 & 0 & 0.0072 & 16 & 0.00 \\
Average & - & $0(0)$ & - & $18(3)$ & $0.00(0.00)$ \\
\hline
\end{tabular}

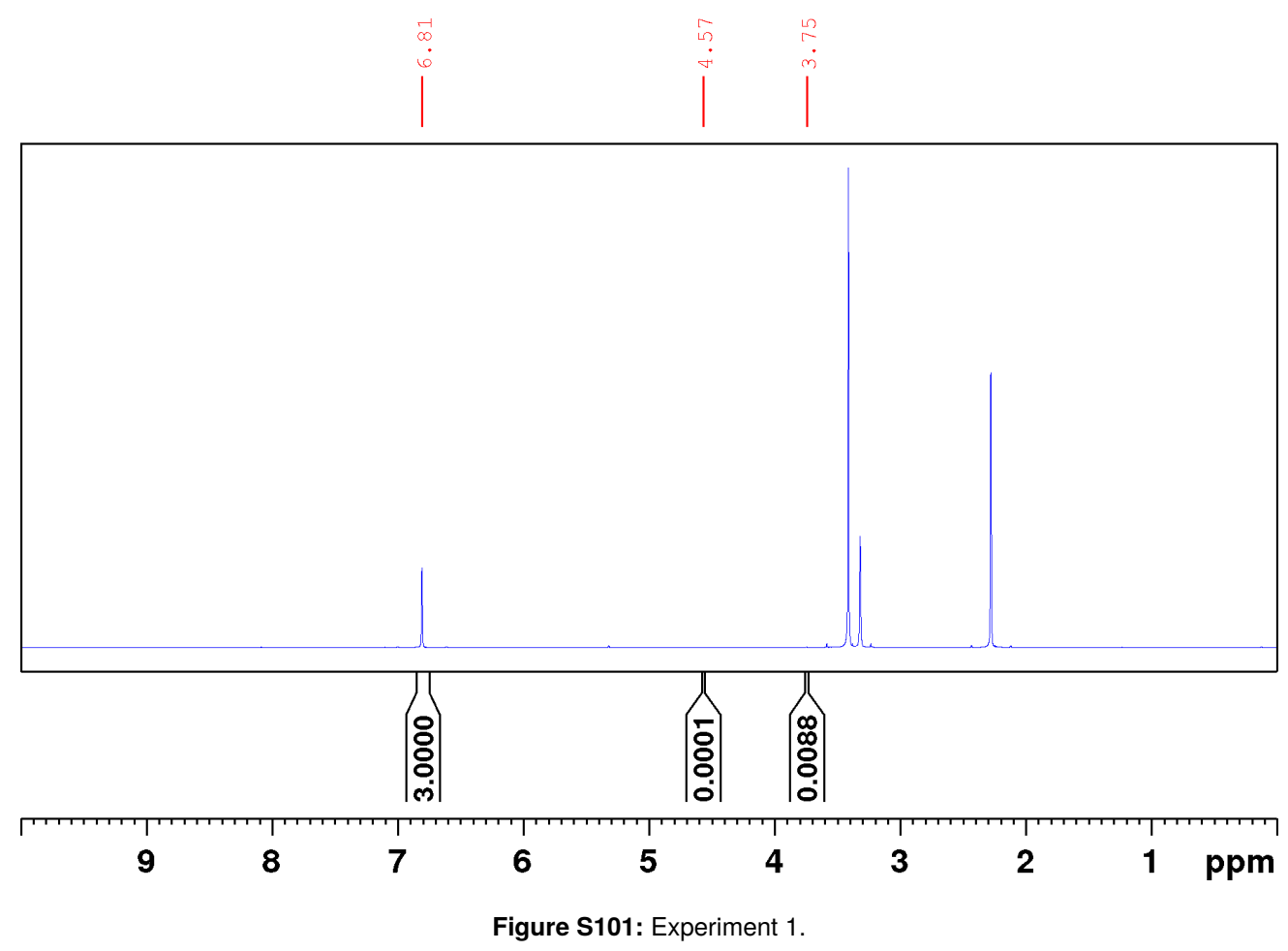




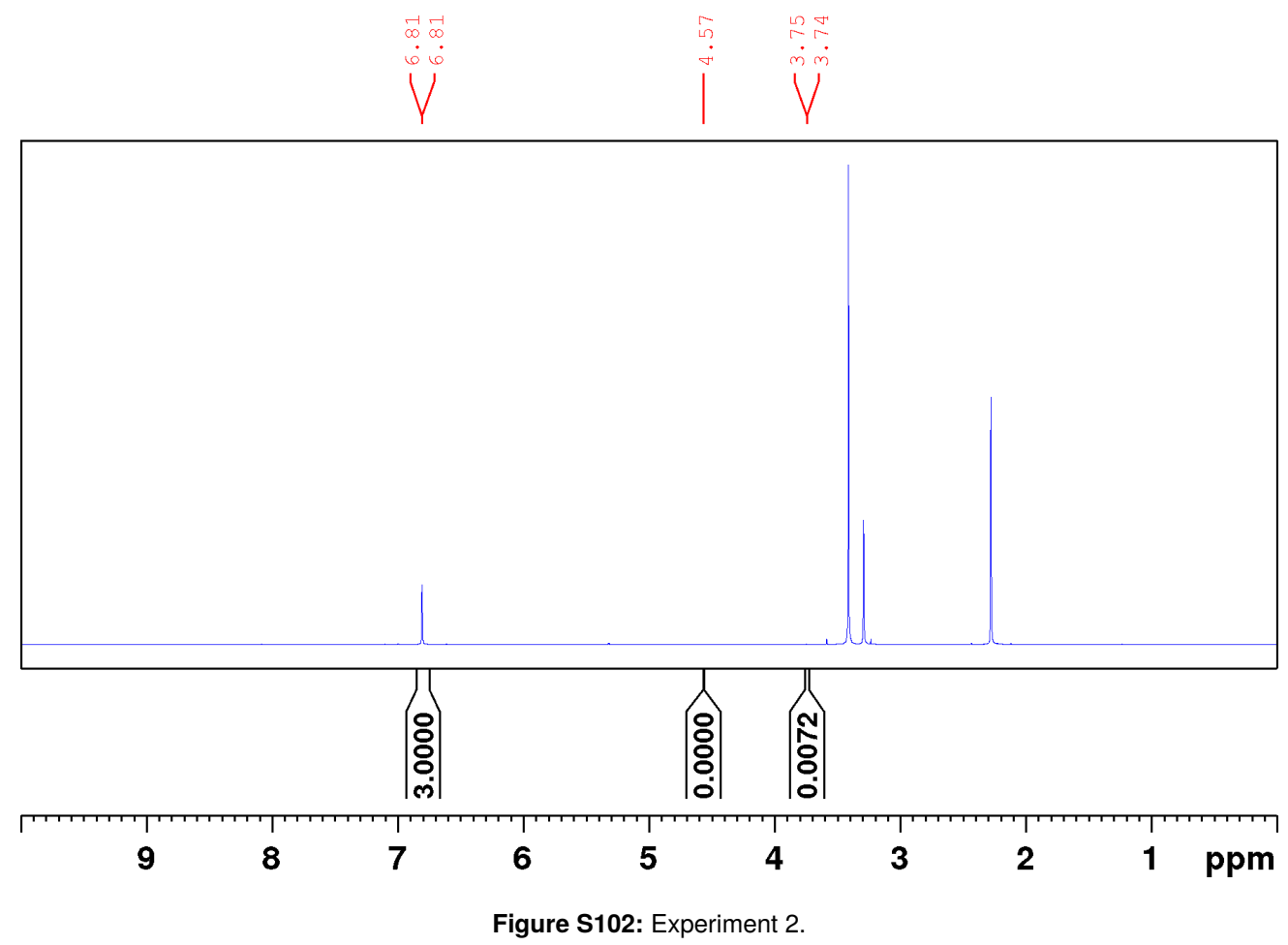




\subsubsection{Run with $\left[R u\left(P\right.\right.$-triphos $\left.\left.{ }^{\mathrm{Ph}}\right)(\mathrm{tmm})\right] 2 \mathrm{2c}$ and without Co-Catalyst}

$$
\begin{aligned}
T & =90{ }^{\circ} \mathrm{C} & n_{\text {cat }} & =0.375 \mu \mathrm{mol} \\
p_{\mathrm{H} 2} & =90 \mathrm{bar} & n_{\mathrm{add}} & =0.00 \mu \mathrm{mol} \\
p_{\mathrm{CO} 2} & =20 \mathrm{bar} & \text { add } & =\text { none } \\
t & =18 \mathrm{~h} & V_{\mathrm{MeOH}} & =0.5 \mathrm{~mL}
\end{aligned}
$$

Table S50: Run with $\left[\mathrm{Ru}\left(P\right.\right.$-triphos $\left.\left.{ }^{\mathrm{Ph}}\right)(\mathrm{tmm})\right]$ 2c and without Co-Catalyst.

\begin{tabular}{lccccc}
\hline & Integral $_{\mathrm{DMM}}$ & $\mathrm{TON}_{\mathrm{DMM}}$ & Integral $_{\mathrm{MF}}$ & $\mathrm{TON}_{\mathrm{MF}}$ & Ratio \\
\hline Experiment 1 & 0.0001 & 0 & 0.0082 & 18 & 0.00 \\
Experiment 2 & 0.0002 & 1 & 0.0079 & 18 & 0.00 \\
Average & - & $1(1)$ & - & $18(0)$ & $0.00(0.00)$ \\
\hline
\end{tabular}

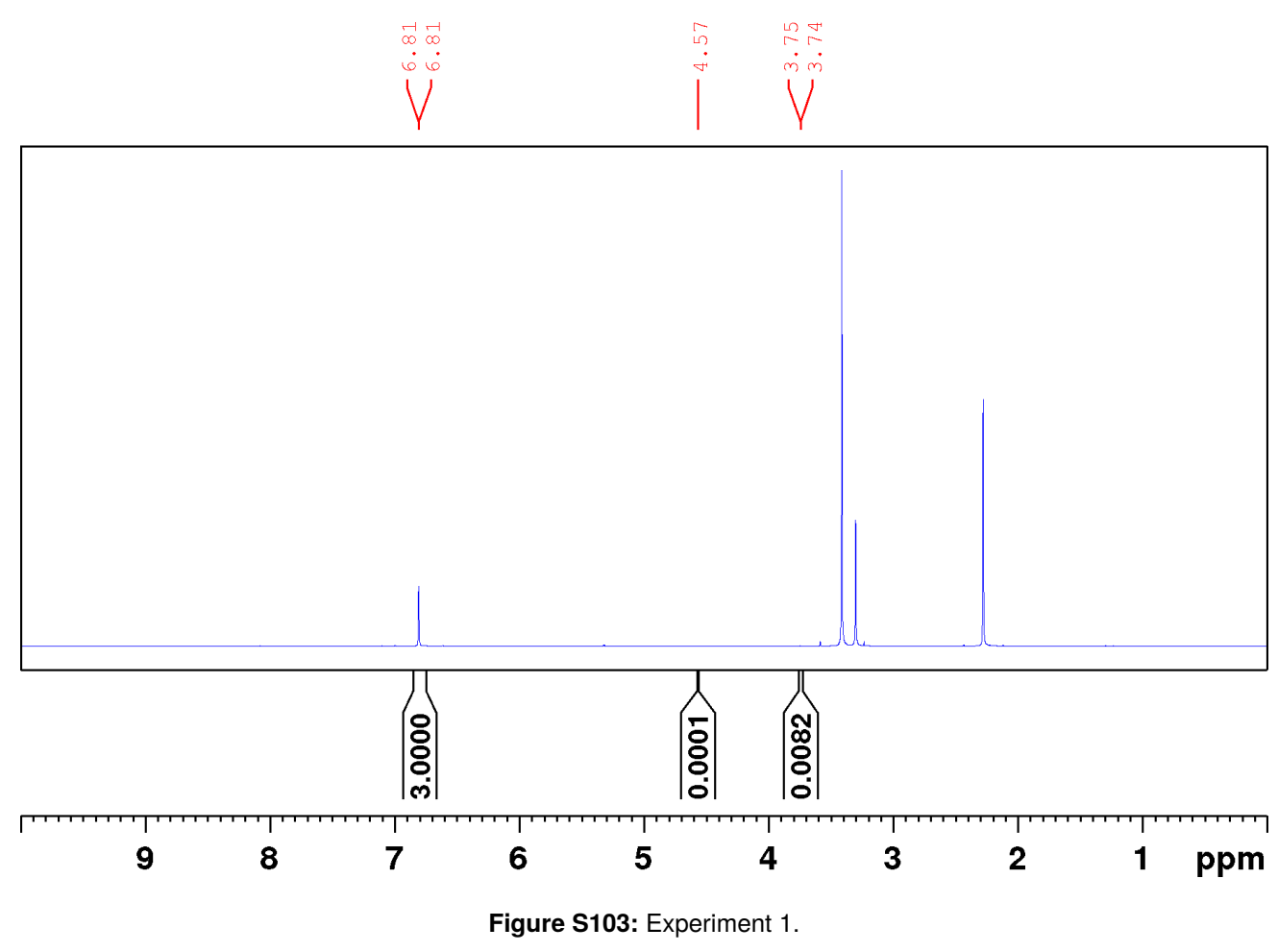




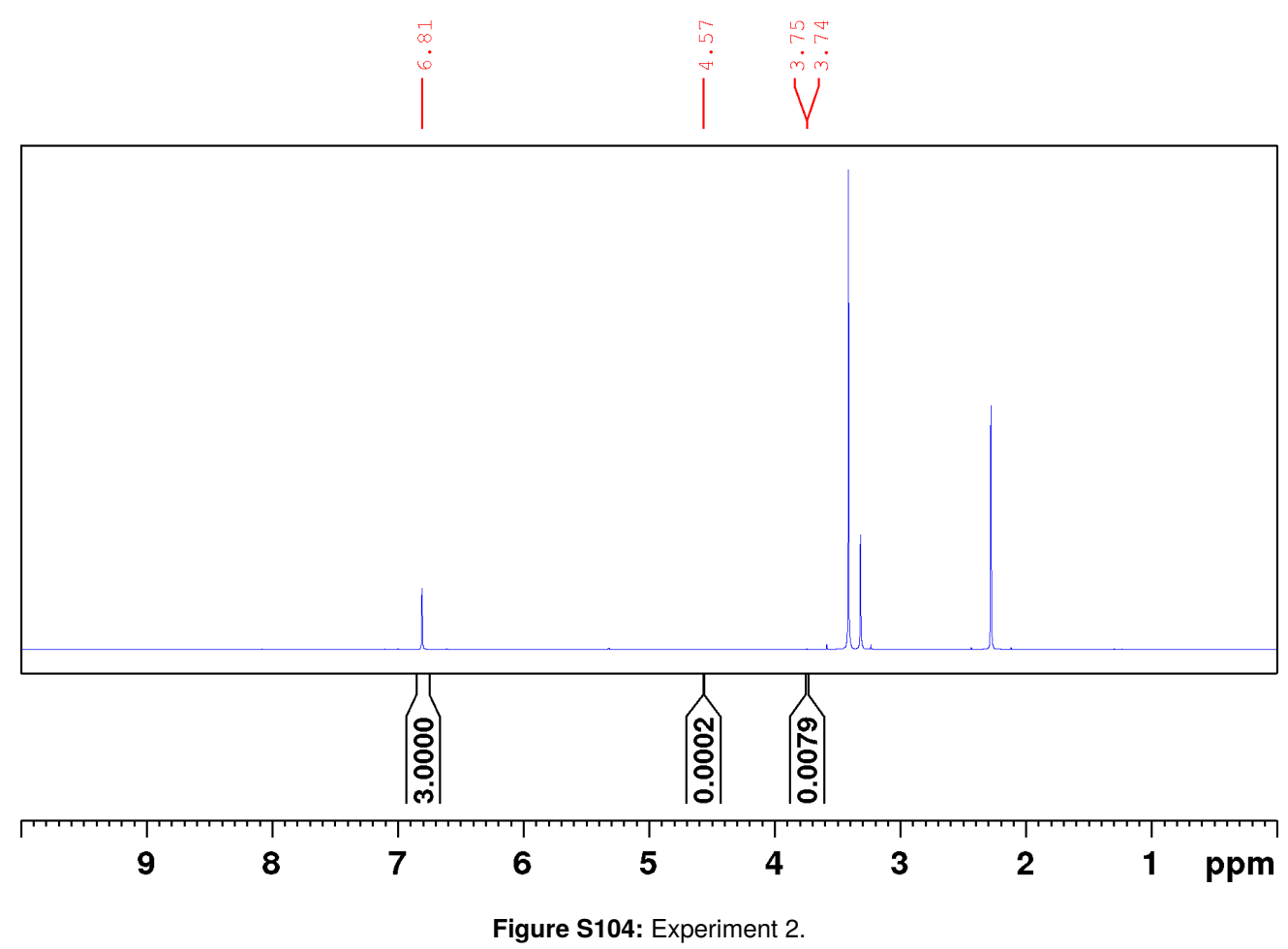




\subsubsection{Run without Catalyst}

$$
\begin{aligned}
T & =90{ }^{\circ} \mathrm{C} & n_{\text {cat }} & =0.00 \mu \mathrm{mol} \\
p_{\mathrm{H} 2} & =90 \mathrm{bar} & n_{\text {add }} & =6.25 \mu \mathrm{mol} \\
p_{\mathrm{CO} 2} & =20 \mathrm{bar} & \text { add } & =\mathrm{Al}(\mathrm{OTf})_{3} \\
t & =18 \mathrm{~h} & V_{\mathrm{MeOH}} & =0.5 \mathrm{~mL}
\end{aligned}
$$

Table S51: Run without catalyst.

\begin{tabular}{lccccc}
\hline & Integral $_{\mathrm{DMM}}$ & $\mathrm{TON}_{\mathrm{DMM}}$ & Integral $_{\mathrm{MF}}$ & $\mathrm{TON}_{\mathrm{MF}}$ & Ratio \\
\hline Experiment 1 & 0.0000 & 0 & 0.0041 & 5 & 0.00 \\
Experiment 2 & 0.0003 & 1 & 0.0049 & 5 & 0.09 \\
Average & - & $0(0)$ & - & $5(1)$ & $0.05(0.06)$ \\
\hline
\end{tabular}

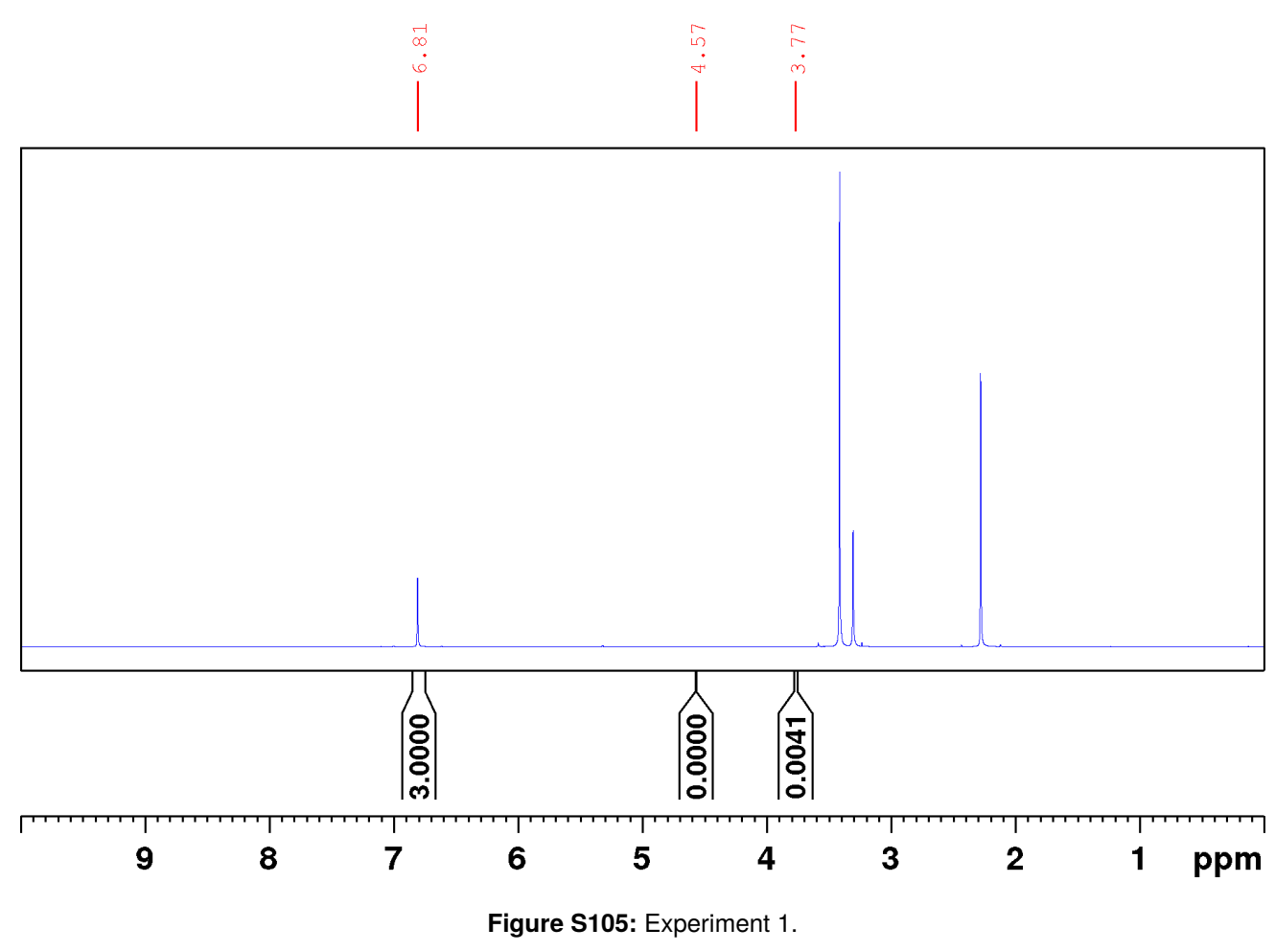




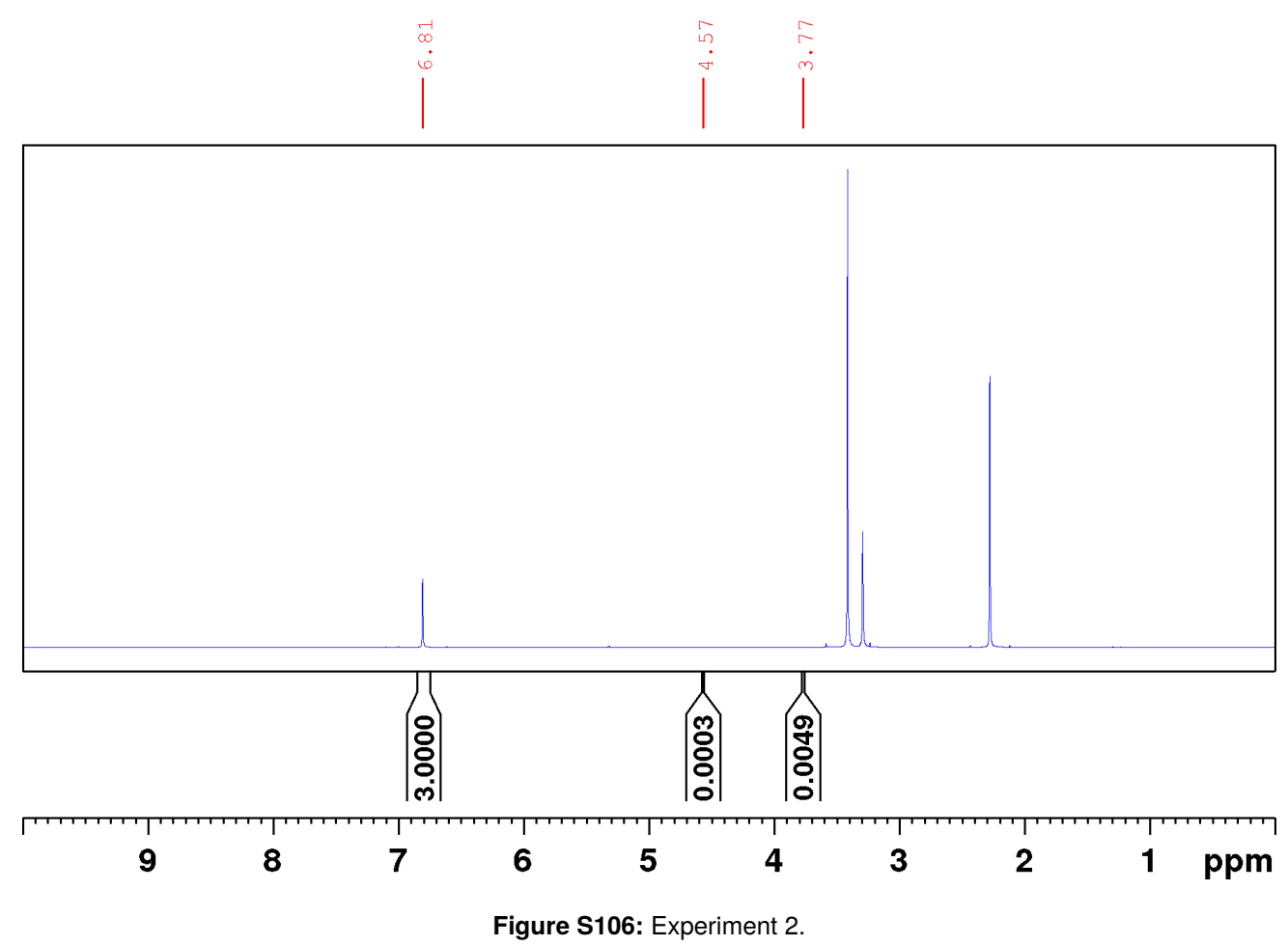




\subsection{Transformation of MF to DMM}

\subsection{1 $\left[\mathrm{Ru}\left({ }^{\mathrm{Ph}}\right.\right.$ Si-triphos $\left.\left.{ }^{\mathrm{Ph}}\right)(\mathrm{tmm})\right] 2 \mathrm{a}$}

$$
\begin{aligned}
T & =90^{\circ} \mathrm{C} & n_{\text {cat }} & =0.375 \mu \mathrm{mol} \\
p_{\mathrm{H} 2} & =90 \mathrm{bar} & n_{\mathrm{add}} & =1.5625 \mu \mathrm{mol} \\
p_{\mathrm{CO} 2} & =0 \mathrm{bar} & \text { add } & =\mathrm{Al}(\mathrm{OTf})_{3} \\
t & =18 \mathrm{~h} & V_{\mathrm{MeOH}} & =0.5 \mathrm{~mL}
\end{aligned}
$$

Table S52: Transformation of MF to DMM using $\left[\mathrm{Ru}\left({ }^{\mathrm{Ph}} \mathrm{Si}-\right.\right.$-triphos $\left.\left.^{\mathrm{Ph}}\right)(\mathrm{tmm})\right] \mathbf{2 a}$.

\begin{tabular}{lccccc}
\hline & Integral $_{\mathrm{DMM}}$ & $\mathrm{TON}_{\mathrm{DMM}}$ & Integral $_{\mathrm{MF}}$ & $\mathrm{TON}_{\mathrm{MF}}$ & Ratio \\
\hline Experiment 1 & 0.0806 & 270 & 0.0021 & 5 & 57.57 \\
Experiment 2 & 0.0827 & 277 & 0.0010 & 2 & 124.05 \\
Average & - & $274(5)$ & - & $4(2)$ & $90.81(47.01)$ \\
\hline
\end{tabular}

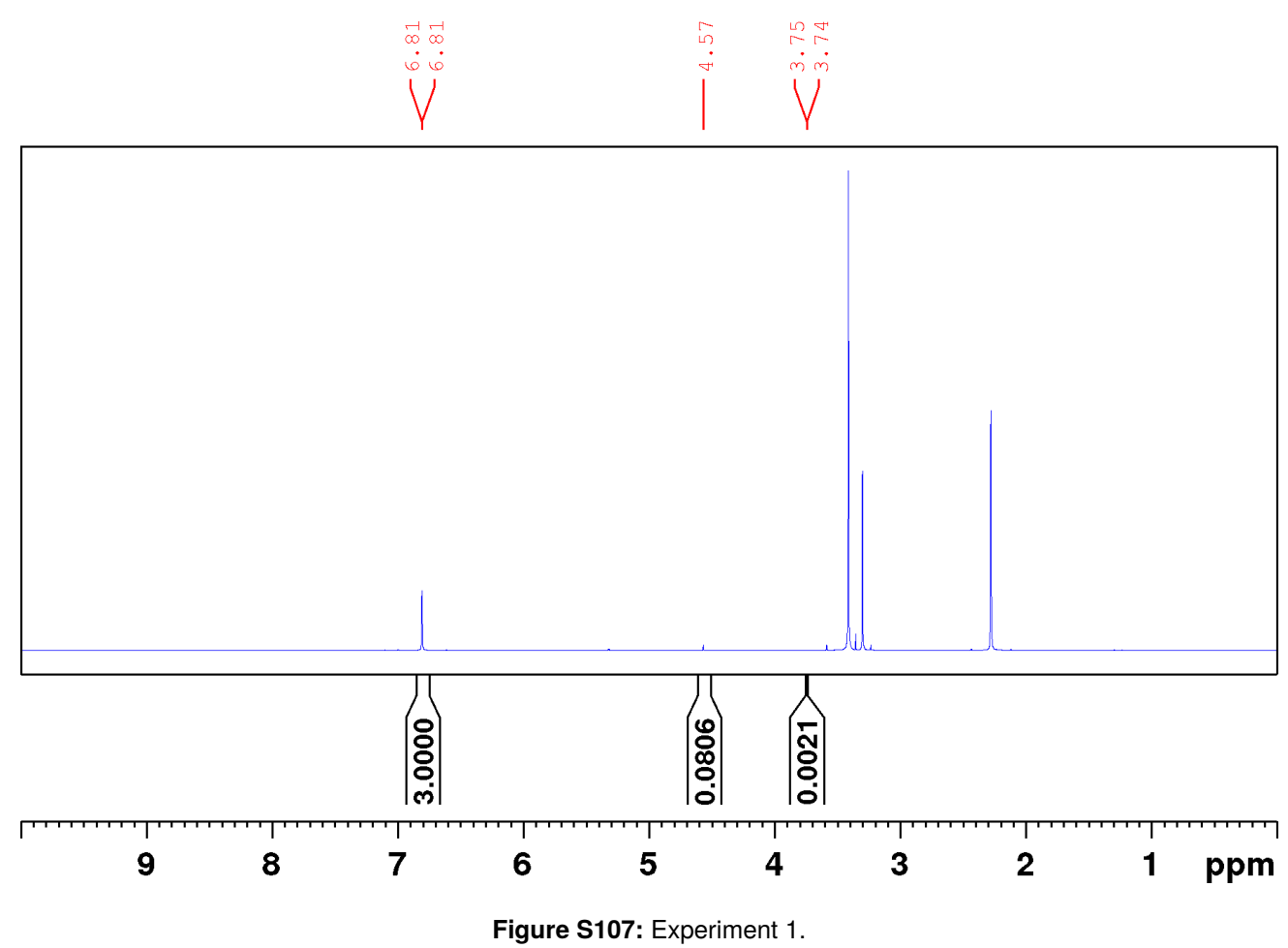




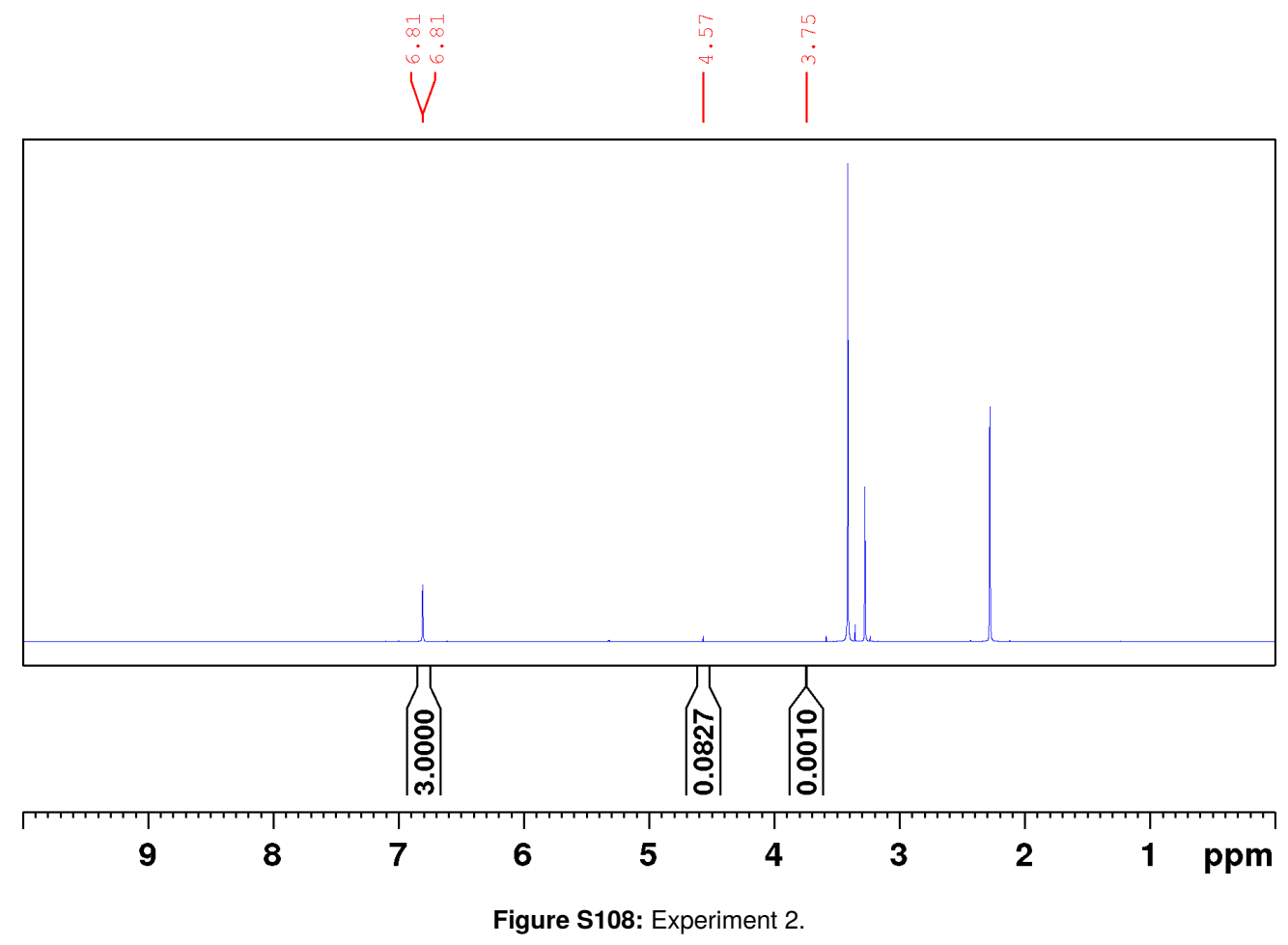




\subsection{2 $\left[\mathrm{Ru}\left({ }^{\mathrm{Me}}{ }^{\mathrm{Si}}\right.\right.$-triphos $\left.\left.{ }^{\mathrm{Ph}}\right)(\mathrm{tmm})\right] 2 \mathrm{~b}$}

$$
\begin{aligned}
T & =90^{\circ} \mathrm{C} & n_{\text {cat }} & =0.375 \mu \mathrm{mol} \\
p_{\mathrm{H} 2} & =90 \mathrm{bar} & n_{\mathrm{add}} & =1.5625 \mu \mathrm{mol} \\
p_{\mathrm{CO} 2} & =0 \mathrm{bar} & \text { add } & =\mathrm{Al}(\mathrm{OTf})_{3} \\
t & =18 \mathrm{~h} & V_{\mathrm{MeOH}} & =0.5 \mathrm{~mL}
\end{aligned}
$$

Table S53: Transformation of MF to DMM using $\left[\mathrm{Ru}\left({ }^{\mathrm{Me}} \mathrm{Si}\right.\right.$-triphos $\left.\left.{ }^{\mathrm{Ph}}\right)(\mathrm{tmm})\right] \mathbf{2 b}$.

\begin{tabular}{lccccc}
\hline & Integral $_{\mathrm{DMM}}$ & $\mathrm{TON}_{\mathrm{DMM}}$ & Integral $_{\mathrm{MF}}$ & $\mathrm{TON}_{\mathrm{MF}}$ & Ratio \\
\hline Experiment 1 & 0.0848 & 284 & 0.0010 & 2 & 127.20 \\
Experiment 2 & 0.0826 & 277 & 0.0009 & 2 & 137.67 \\
Average & - & $281(5)$ & - & $2(0)$ & $132.43(7.40)$ \\
\hline
\end{tabular}

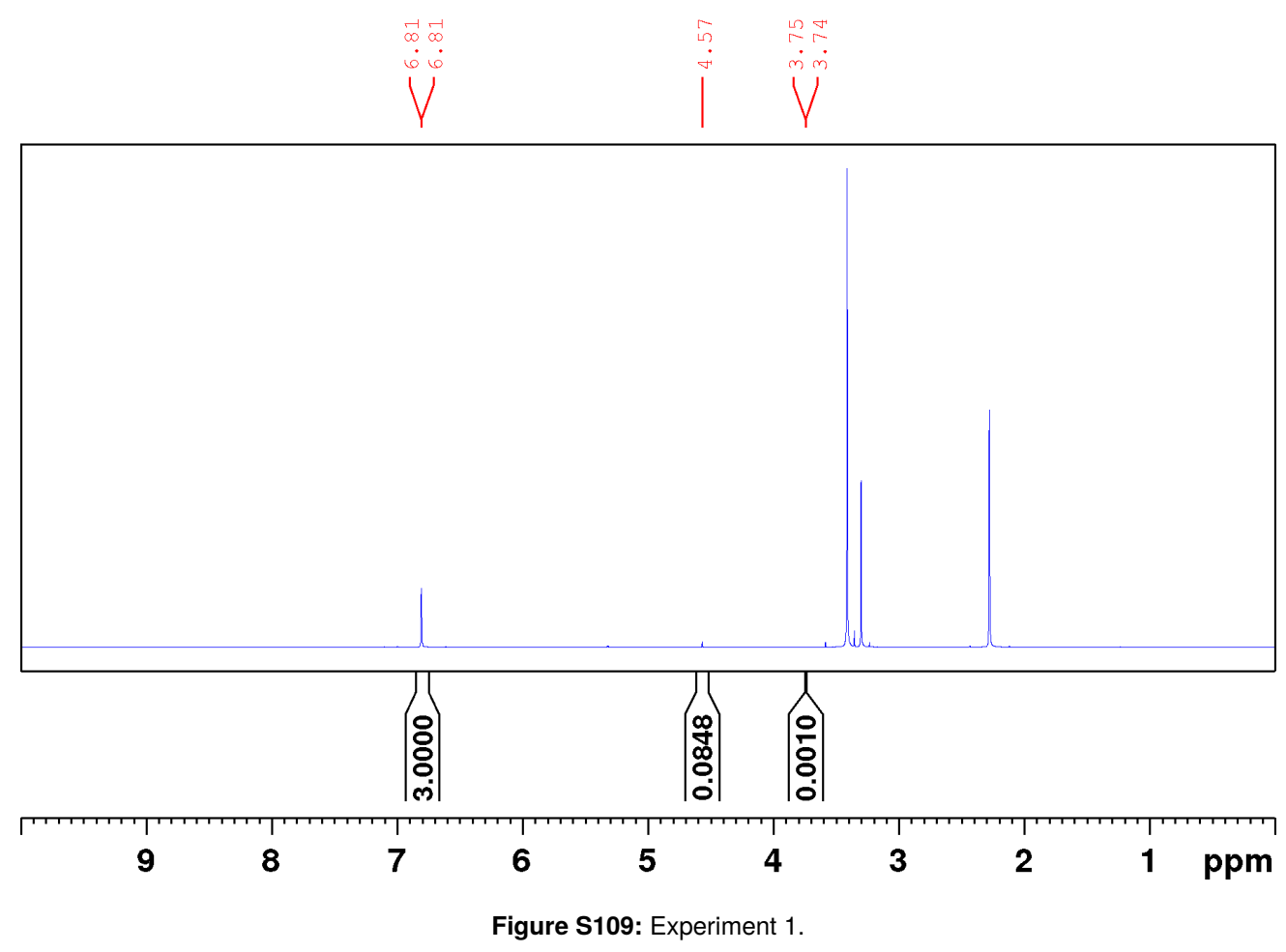









\subsection{3 $\left[R u\left(P\right.\right.$-triphos $\left.\left.{ }^{\mathrm{Ph}}\right)(\mathrm{tmm})\right] 2 \mathrm{c}$}

$$
\begin{aligned}
\mathrm{T} & =90^{\circ} \mathrm{C} & n_{\mathrm{cat}} & =0.375 \mu \mathrm{mol} \\
p_{\mathrm{H} 2} & =90 \mathrm{bar} & n_{\mathrm{add}} & =1.5625 \mu \mathrm{mol} \\
p_{\mathrm{CO} 2} & =0 \mathrm{bar} & \text { add } & =\mathrm{Al}(\mathrm{OTf})_{3} \\
t & =18 \mathrm{~h} & V_{\mathrm{MeOH}} & =0.5 \mathrm{~mL}
\end{aligned}
$$

Table S54: Transformation of MF to DMM using $\left[\mathrm{Ru}\left(P\right.\right.$-triphos $\left.\left.{ }^{\mathrm{Ph}}\right)(\mathrm{tmm})\right] 2 \mathrm{2c}$.

\begin{tabular}{lccccc}
\hline & Integral $_{\mathrm{DMM}}$ & $\mathrm{TON}_{\mathrm{DMM}}$ & Integral $_{\mathrm{MF}}$ & $\mathrm{TON}_{\mathrm{MF}}$ & Ratio \\
\hline Experiment 1 & 0.0623 & 209 & 0.0014 & 3 & 66.75 \\
Experiment 2 & 0.0605 & 203 & 0.0014 & 3 & 64.82 \\
Average & - & $206(4)$ & - & $3(0)$ & $65.79(1.36)$ \\
\hline
\end{tabular}

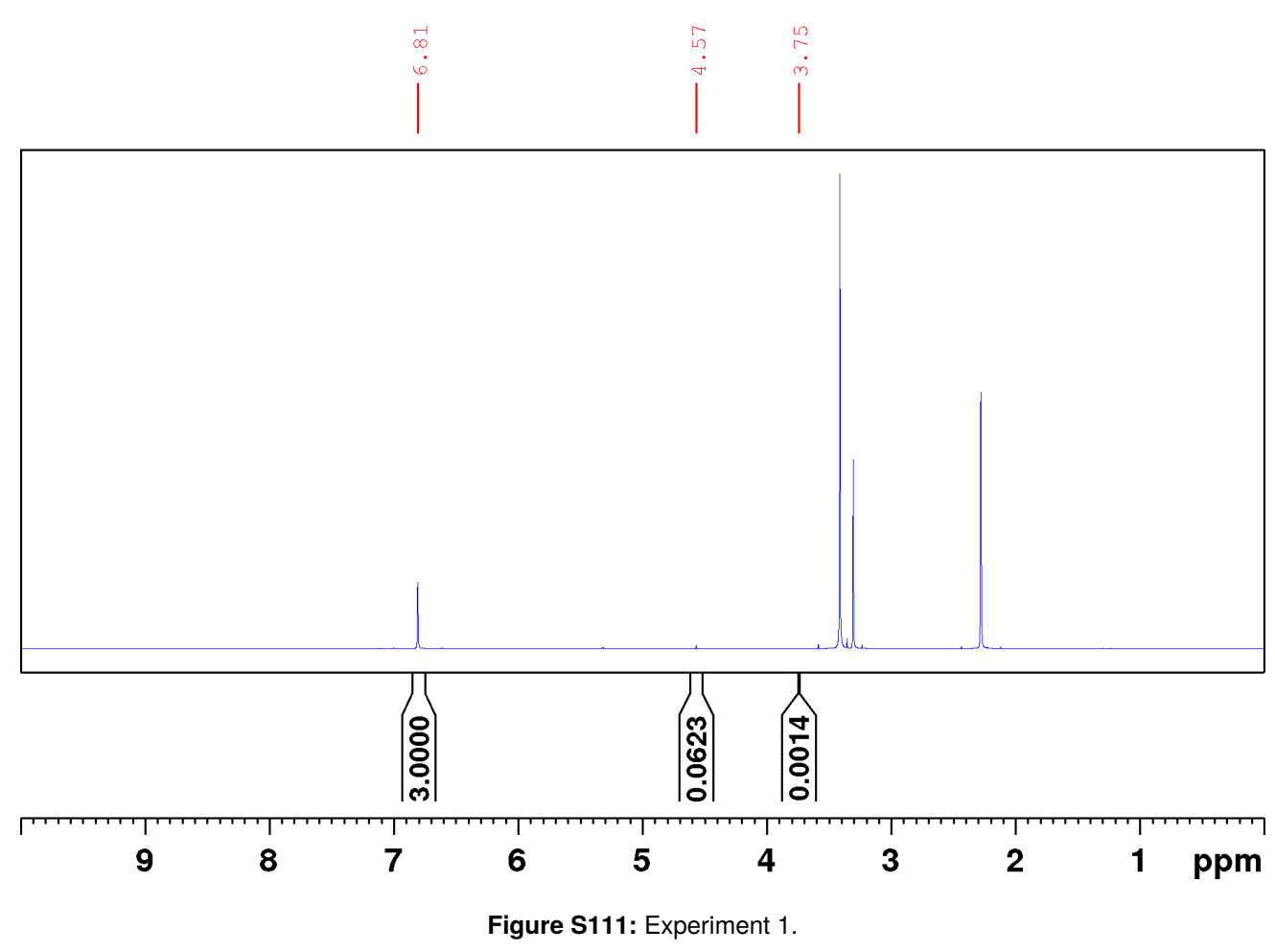




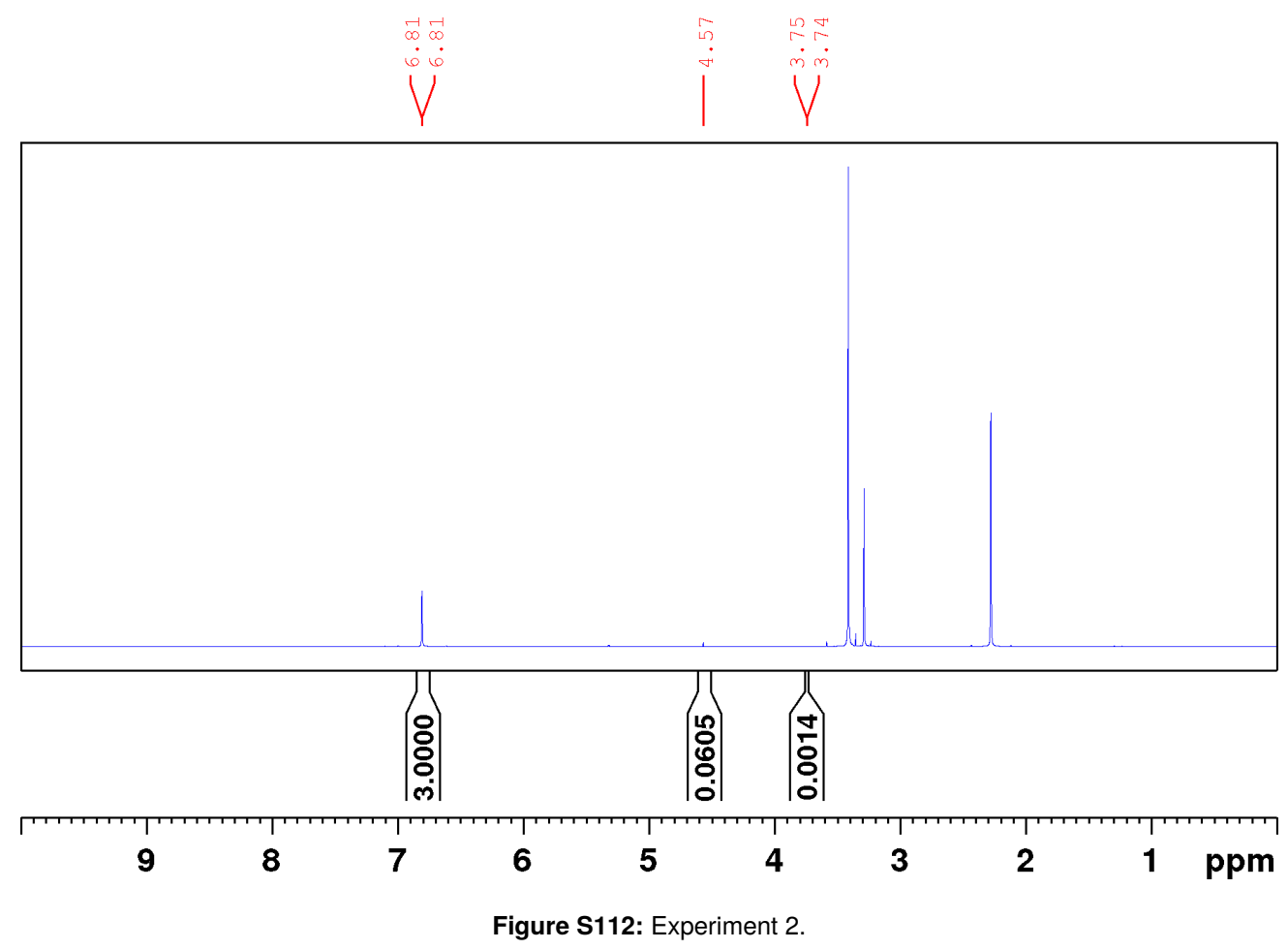




\section{X-Ray Crystallographic Data}

\subsection{Data of $\left[\mathrm{Ru}\left({ }^{\mathrm{Ph}}{ }^{\mathrm{Si}}\right.\right.$-triphos $\left.\left.{ }^{\mathrm{Ph}}\right)(\mathrm{tmm})\right] 2 \mathrm{a}$}



Figure S113: Molecular structure of $\left[\mathrm{Ru}\left({ }^{\mathrm{Ph}} \mathrm{Si}\right.\right.$-triphos $\left.\left.{ }^{\mathrm{Ph}}\right)(\mathrm{tmm})\right]$ 2a. Ellipsoids are shown at the $50 \%$ probability level. Hydrogen atoms are omitted for clarity.

Refined as a two-component twin (BASF 0.44). The solvent could not be refined well and was excluded using SQUEEZE. The solvent is most likely methylene chloride. 
Table S55: Crystal data and structure refinement for $\left[\mathrm{Ru}\left({ }^{\mathrm{Ph}} \mathrm{Si}\right.\right.$-triphos $\left.\left.{ }^{\mathrm{Ph}}\right)(\mathrm{tmm})\right] \mathbf{2 a}$.

\begin{tabular}{|c|c|}
\hline Molecule & $2 a$ \\
\hline CCDC number & 1890032 \\
\hline Empirical formula & $\mathrm{C}_{49} \mathrm{H}_{47} \mathrm{P}_{3} \mathrm{RuSi}$ \\
\hline Formula weight $/ \mathrm{g} \mathrm{mol}^{-1}$ & 857.93 \\
\hline Temperature / K & $111(2)$ \\
\hline Wavelength $\lambda / \AA$ & 0.71073 \\
\hline Crystal system & triclinic \\
\hline Space group & $P \overline{1}$ \\
\hline$a / \AA$ & $13.5474(17)$ \\
\hline$b / \AA$ & $13.5526(17)$ \\
\hline$c / \AA$ & $16.2611(19)$ \\
\hline$\alpha /{ }^{\circ}$ & 87.382(3) \\
\hline$\beta / \circ$ & $71.590(3)$ \\
\hline$\gamma / \circ$ & $60.729(3)$ \\
\hline Cell volume $V / \AA^{3}$ & $2449.7(5)$ \\
\hline Units per cell $Z$ & 2 \\
\hline Density $\rho$ (calculated) $/ \mathrm{g} \mathrm{cm}^{-3}$ & 1.163 \\
\hline Absorption coefficient $\mu / \mathrm{mm}^{-1}$ & 0.471 \\
\hline Crystal size / $\mathrm{mm}^{3}$ & $0.060 \times 0.050 \times 0.030$ \\
\hline Absorption correction & Multi-Scan \\
\hline Transmission factor range & $0.88-0.99$ \\
\hline Reflections measured & 11121 \\
\hline$R_{\text {int }}$ & 0.0617 \\
\hline Mean $\sigma(\mathrm{I}) / \mathrm{I}$ & 0.0436 \\
\hline$\theta$ range $/^{\circ}$ & $2.866-27.485$ \\
\hline Observed reflections & 10515 \\
\hline$x, y$ (weighting scheme) & $0.0517,5.6980$ \\
\hline Hydrogen refinement & constraint \\
\hline Reflections in refinement & 11121 \\
\hline Parameters / Restraints & $488 / 0$ \\
\hline$R\left(F_{\text {obs }}\right)$ & 0.0434 \\
\hline$R_{\mathrm{W}}\left(F^{2}\right)$ & 0.1193 \\
\hline Goodness-of-fit $S$ & 1.051 \\
\hline Shift/error $\max$ & 0.001 \\
\hline Max electron density / e $\AA^{-3}$ & 1.252 \\
\hline Min electron density / e $\AA^{-3}$ & -1.274 \\
\hline
\end{tabular}




\subsection{Data of $\left[R u\left({ }^{M e}\right.\right.$ Si-triphos $\left.\left.{ }^{\mathrm{Ph}}\right)(\mathrm{tmm})\right] 2 \mathrm{2b}$}

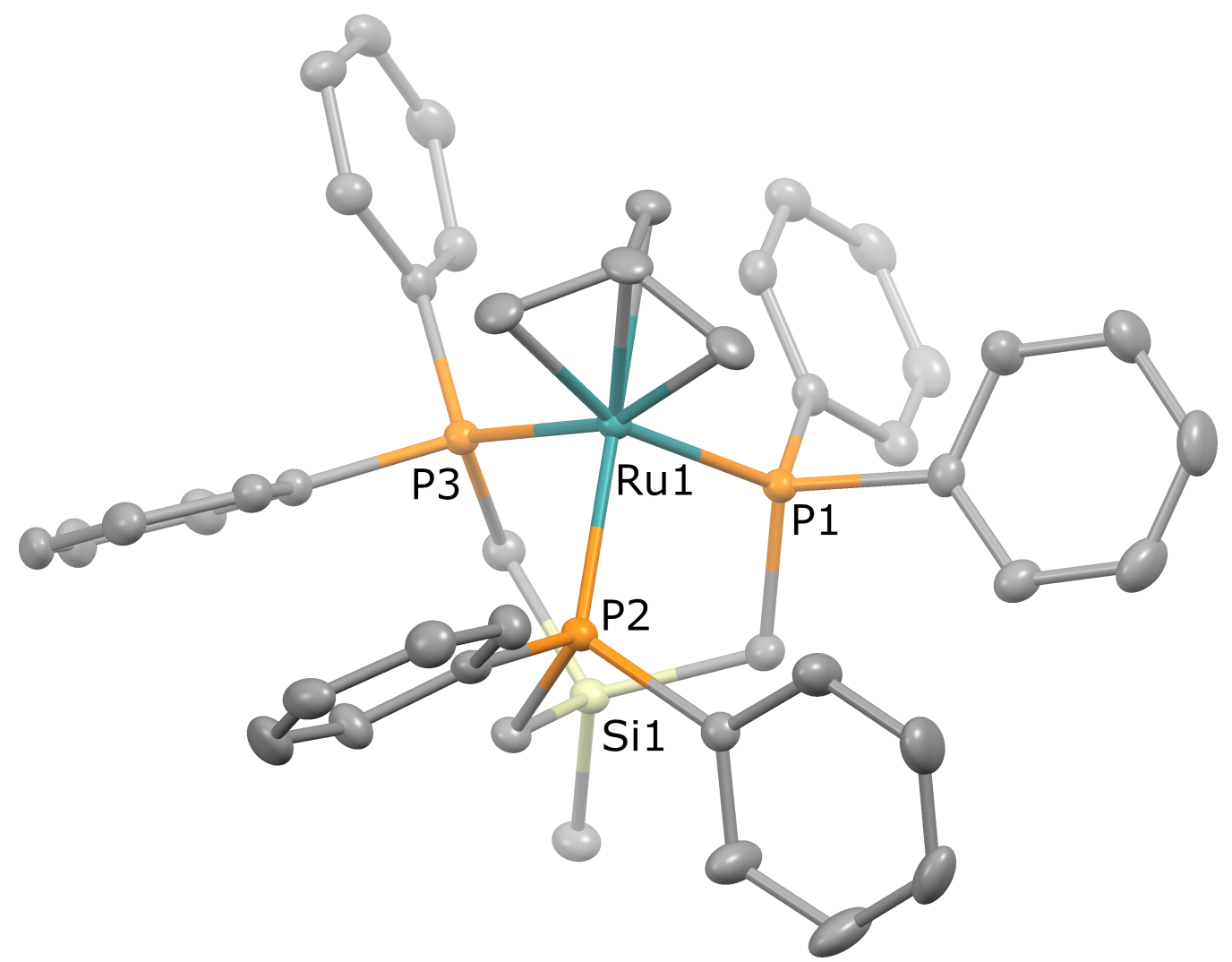

Figure S114: Molecular structure of $\left[\mathrm{Ru}\left({ }^{\mathrm{Me}} \mathrm{Si}\right.\right.$-triphos $\left.\left.{ }^{\mathrm{Ph}}\right)(\mathrm{tmm})\right]$ 2b. Ellipsoids are shown at the $50 \%$ probability level. Hydrogen atoms are omitted for clarity. 
Table S56: Crystal data and structure refinement for $\left[\mathrm{Ru}\left({ }^{\mathrm{Me}} \mathrm{Si}\right.\right.$-triphos $\left.\left.{ }^{\mathrm{Ph}}\right)(\mathrm{tmm})\right] \mathbf{2 b}$.

\begin{tabular}{|c|c|}
\hline Molecule & $2 b$ \\
\hline CCDC number & 1890031 \\
\hline Empirical formula & $\mathrm{C}_{44} \mathrm{H}_{45} \mathrm{P}_{3} \mathrm{RuSi}$ \\
\hline Formula weight $/ \mathrm{g} \mathrm{mol}^{-1}$ & 795.87 \\
\hline Temperature / K & $112(2)$ \\
\hline Wavelength $\lambda / \AA$ & 0.71073 \\
\hline Crystal system & orthorhombic \\
\hline Space group & $P n a 2_{1}$ \\
\hline$a / \AA$ & $17.9947(8)$ \\
\hline$b / \AA$ & $11.9315(5)$ \\
\hline$c / \AA$ & $17.2774(8)$ \\
\hline$\alpha / \circ$ & 90 \\
\hline$\beta / \circ$ & 90 \\
\hline$\gamma / \circ$ & 90 \\
\hline Cell volume $V / \AA^{3}$ & $3709.5(3)$ \\
\hline Units per cell Z & 4 \\
\hline Density $\rho$ (calculated) $/ \mathrm{g} \mathrm{cm}^{-3}$ & 1.425 \\
\hline Absorption coefficient $\mu / \mathrm{mm}^{-1}$ & 0.616 \\
\hline Crystal size $/ \mathrm{mm}^{3}$ & $0.040 \times 0.030 \times 0.020$ \\
\hline Absorption correction & Multi-Scan \\
\hline Transmission factor range & $0.92-0.99$ \\
\hline Reflections measured & 57965 \\
\hline$R_{\text {int }}$ & 0.0557 \\
\hline Mean $\sigma(\mathrm{I}) / \mathrm{I}$ & 0.0363 \\
\hline$\theta$ range $/{ }^{\circ}$ & $3.071-27.482$ \\
\hline Observed reflections & 7803 \\
\hline$x, y$ (weighting scheme) & $0.0224,1.7519$ \\
\hline Hydrogen refinement & constraint \\
\hline Flack parameter & $-0.014(12)$ \\
\hline Reflections in refinement & 8495 \\
\hline Parameters / Restraints & $443 / 6$ \\
\hline$R\left(F_{\text {obs }}\right)$ & 0.0271 \\
\hline$R_{\mathrm{W}}\left(F^{2}\right)$ & 0.0604 \\
\hline Goodness-of-fit $S$ & 1.060 \\
\hline Shift/error $\max$ & 0.002 \\
\hline Max electron density / e $\AA^{-3}$ & 0.470 \\
\hline Min electron density / $e \AA^{-3}$ & -0.452 \\
\hline
\end{tabular}




\section{Appendix}

\subsection{NMR Spectra of the Ligands}

\subsection{1 ${ }^{\mathrm{Ph}}$ Si-triphos ${ }^{\mathrm{Ph}} 1 \mathrm{a}$}



Figure S115: ${ }^{1} \mathrm{H}$ NMR $\left(\mathrm{CD}_{2} \mathrm{Cl}_{2}, 400 \mathrm{MHz}, 298 \mathrm{~K}\right)$ spectrum of compound 1a. 


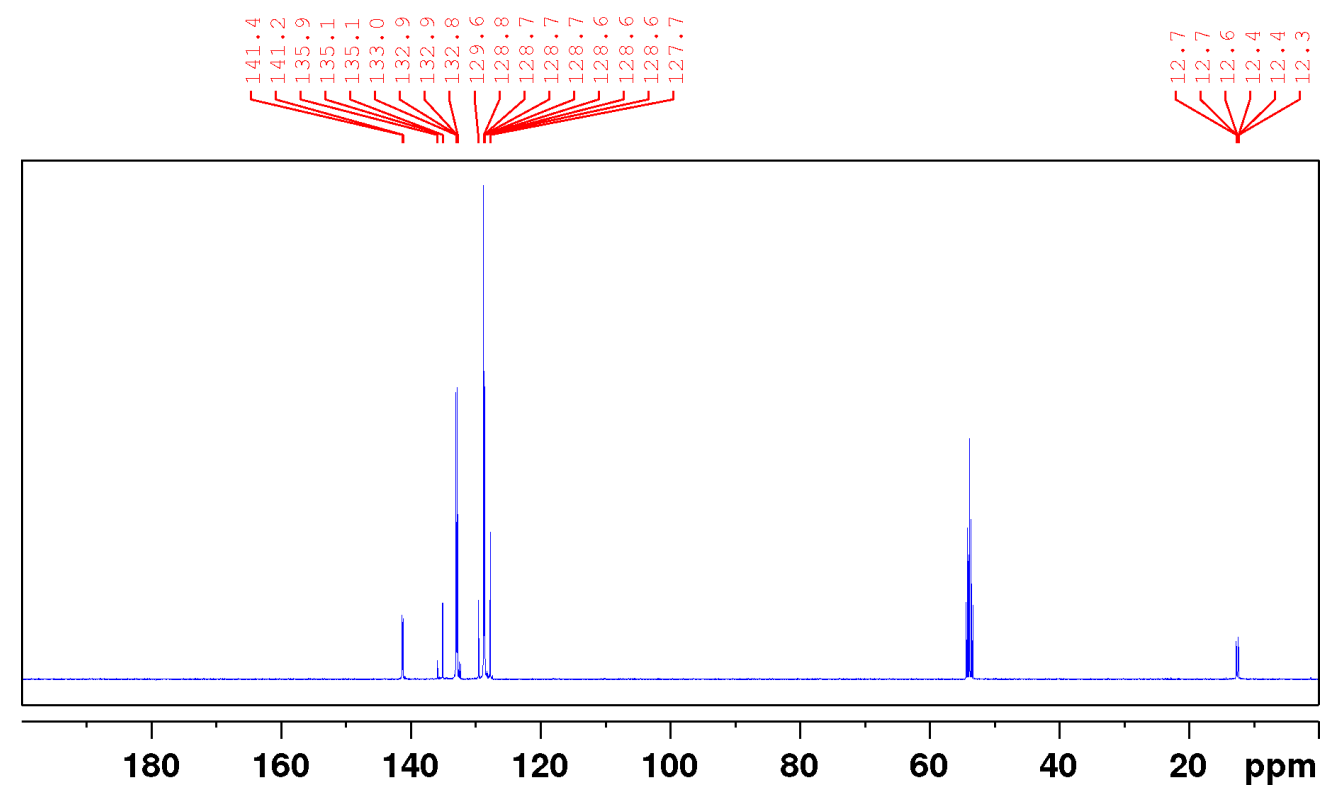

Figure S116: ${ }^{13} \mathrm{C}\left\{{ }^{1} \mathrm{H}\right\} \mathrm{NMR}\left(\mathrm{CD}_{2} \mathrm{Cl}_{2}, 101 \mathrm{MHz}, 298 \mathrm{~K}\right)$ spectrum of compound 1a.

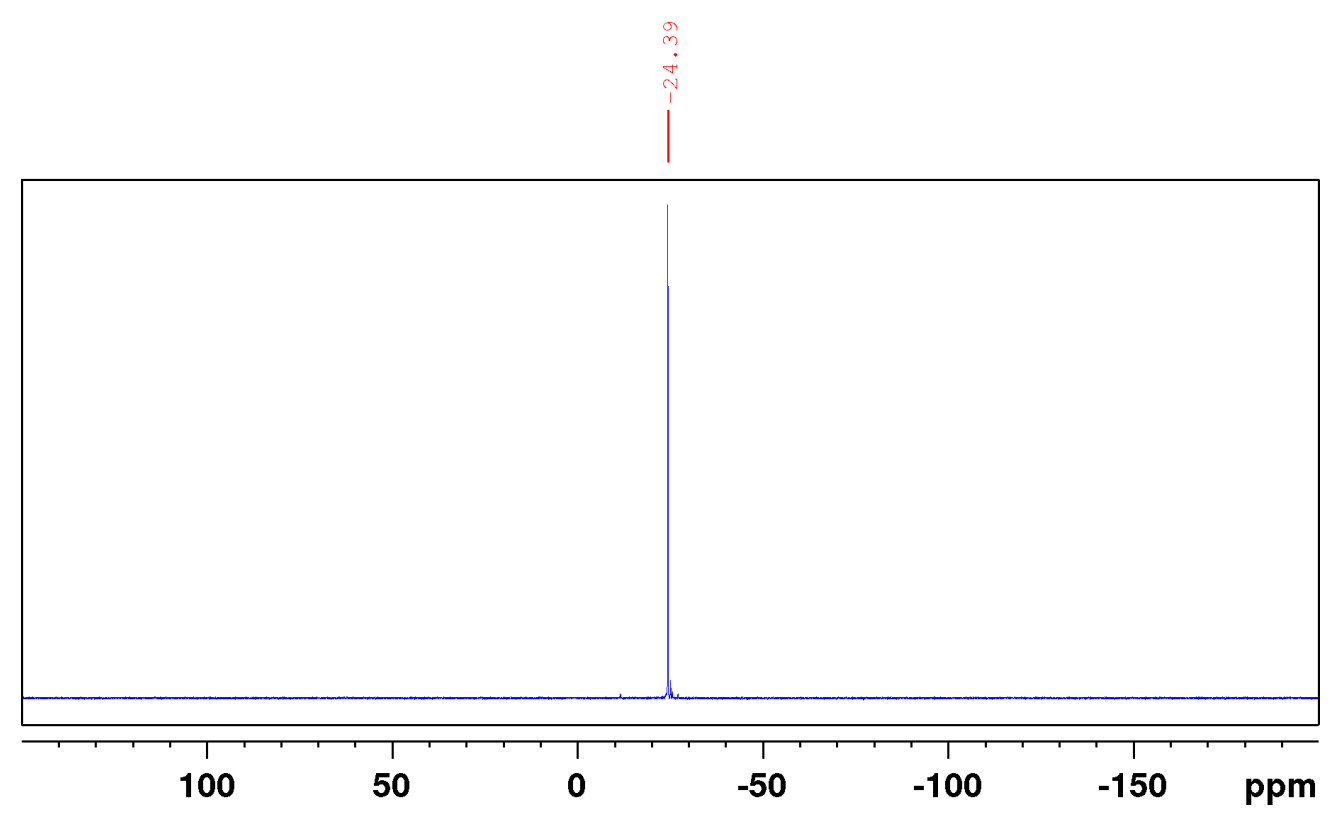

Figure S117: ${ }^{31} \mathrm{P}\left\{{ }^{1} \mathrm{H}\right\} \mathrm{NMR}\left(\mathrm{CD}_{2} \mathrm{Cl}_{2}, 162 \mathrm{MHz}, 298 \mathrm{~K}\right)$ spectrum of compound 1a. 


\subsection{2 ${ }^{\mathrm{Me}}$ Si-triphos ${ }^{\mathrm{Ph}} 1 \mathrm{~b}$}

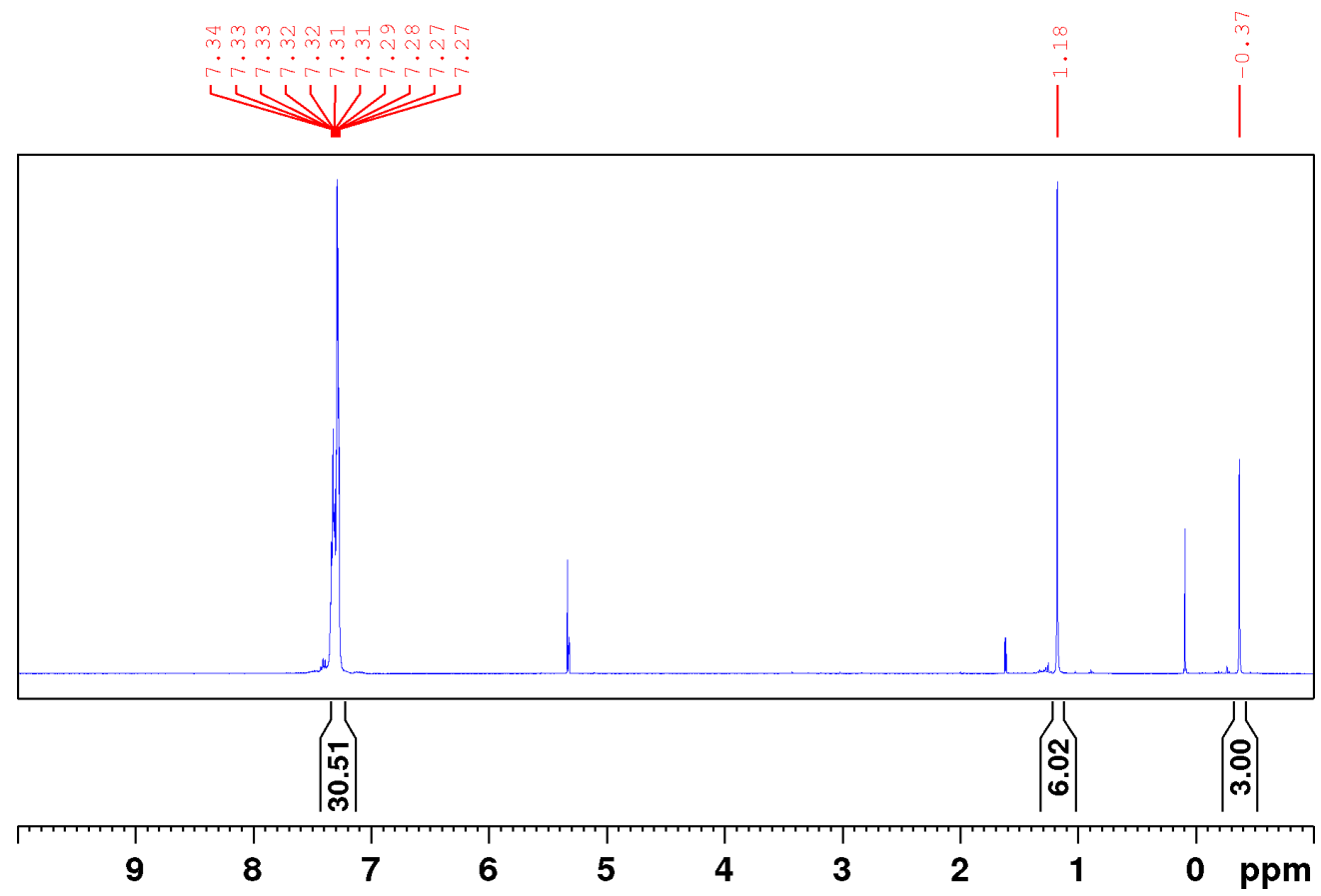

Figure S118: ${ }^{1} \mathrm{H} \mathrm{NMR}\left(\mathrm{CD}_{2} \mathrm{Cl}_{2}, 400 \mathrm{MHz}, 298 \mathrm{~K}\right)$ spectrum of compound $\mathbf{1 b}$.

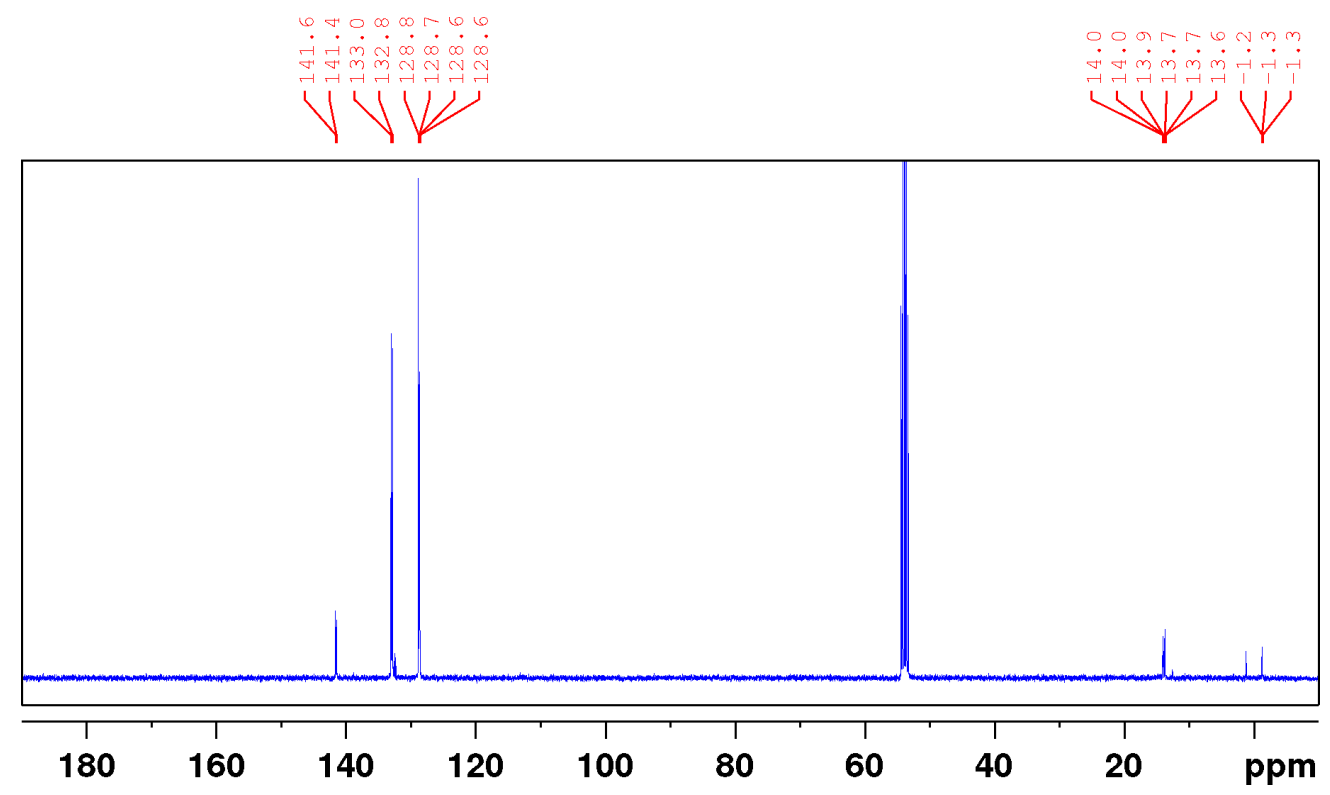

Figure S119: ${ }^{13} \mathrm{C}\left\{{ }^{1} \mathrm{H}\right\} \mathrm{NMR}\left(\mathrm{CD}_{2} \mathrm{Cl}_{2}, 101 \mathrm{MHz}, 298 \mathrm{~K}\right)$ spectrum of compound $\mathbf{1 b}$. 


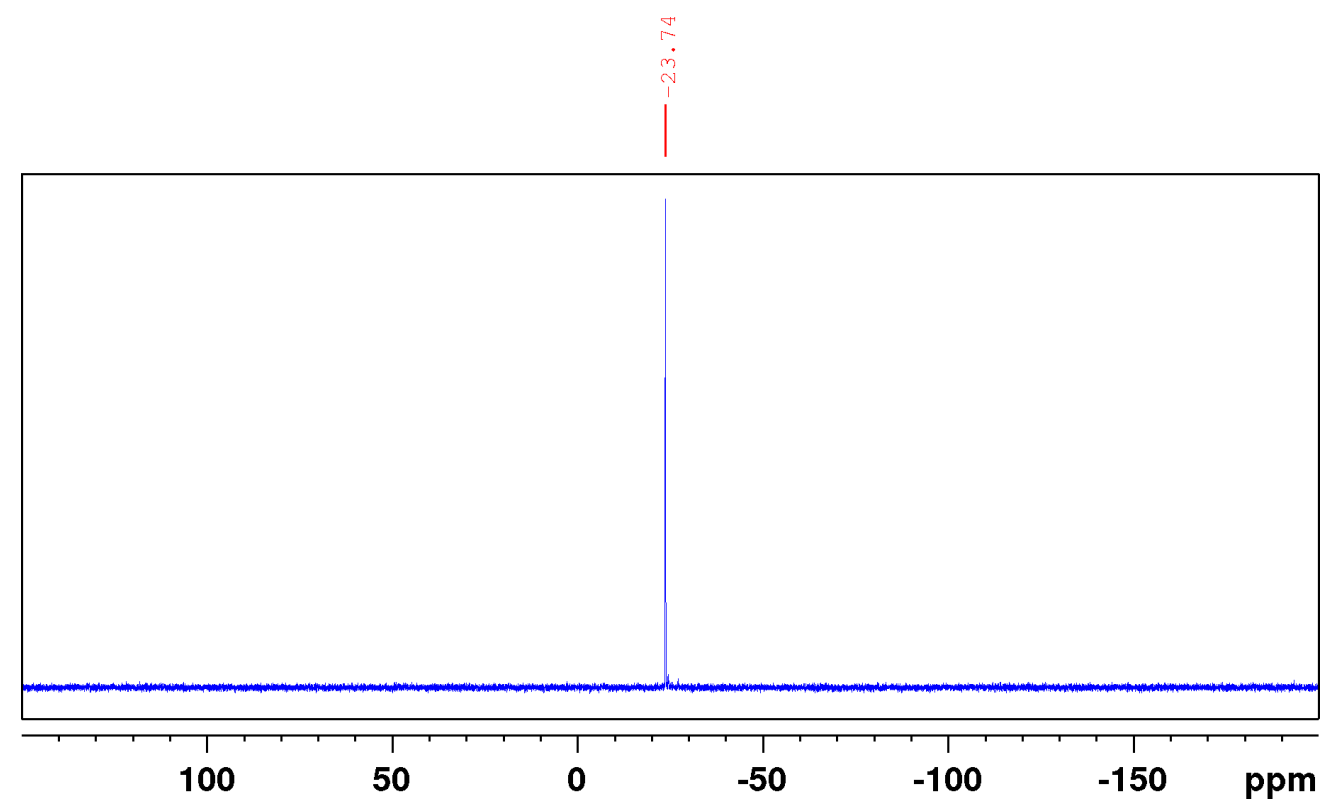

Figure S120: ${ }^{31} \mathrm{P}\left\{{ }^{1} \mathrm{H}\right\} \mathrm{NMR}\left(\mathrm{CD}_{2} \mathrm{Cl}_{2}, 162 \mathrm{MHz}, 298 \mathrm{~K}\right)$ spectrum of compound $\mathbf{1 b}$ 


\subsubsection{P-triphos ${ }^{\mathrm{Ph}}$ 1c}

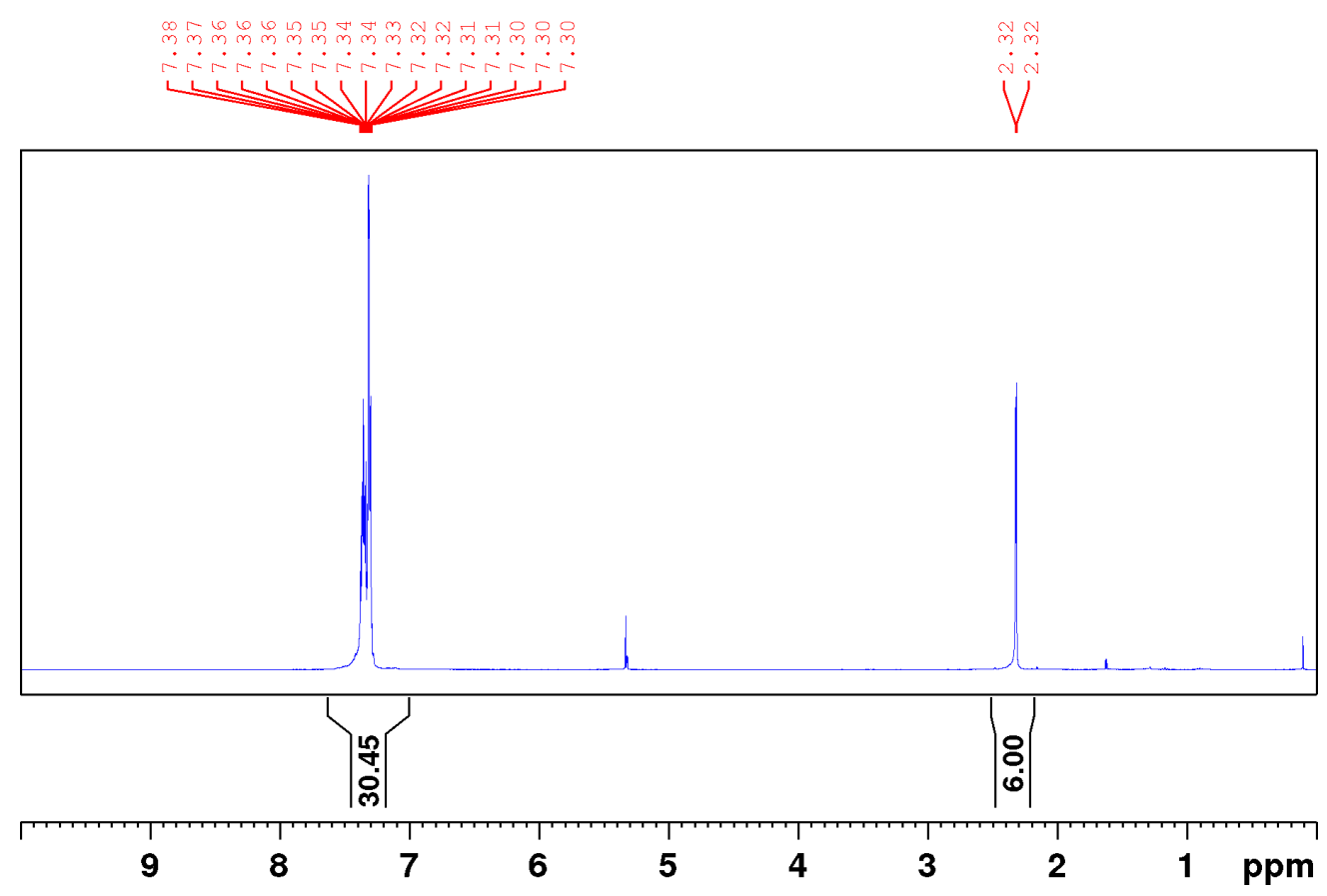

Figure S121: ${ }^{1} \mathrm{H} \mathrm{NMR}\left(\mathrm{CD}_{2} \mathrm{Cl}_{2}, 400 \mathrm{MHz}, 298 \mathrm{~K}\right)$ spectrum of compound 1c.

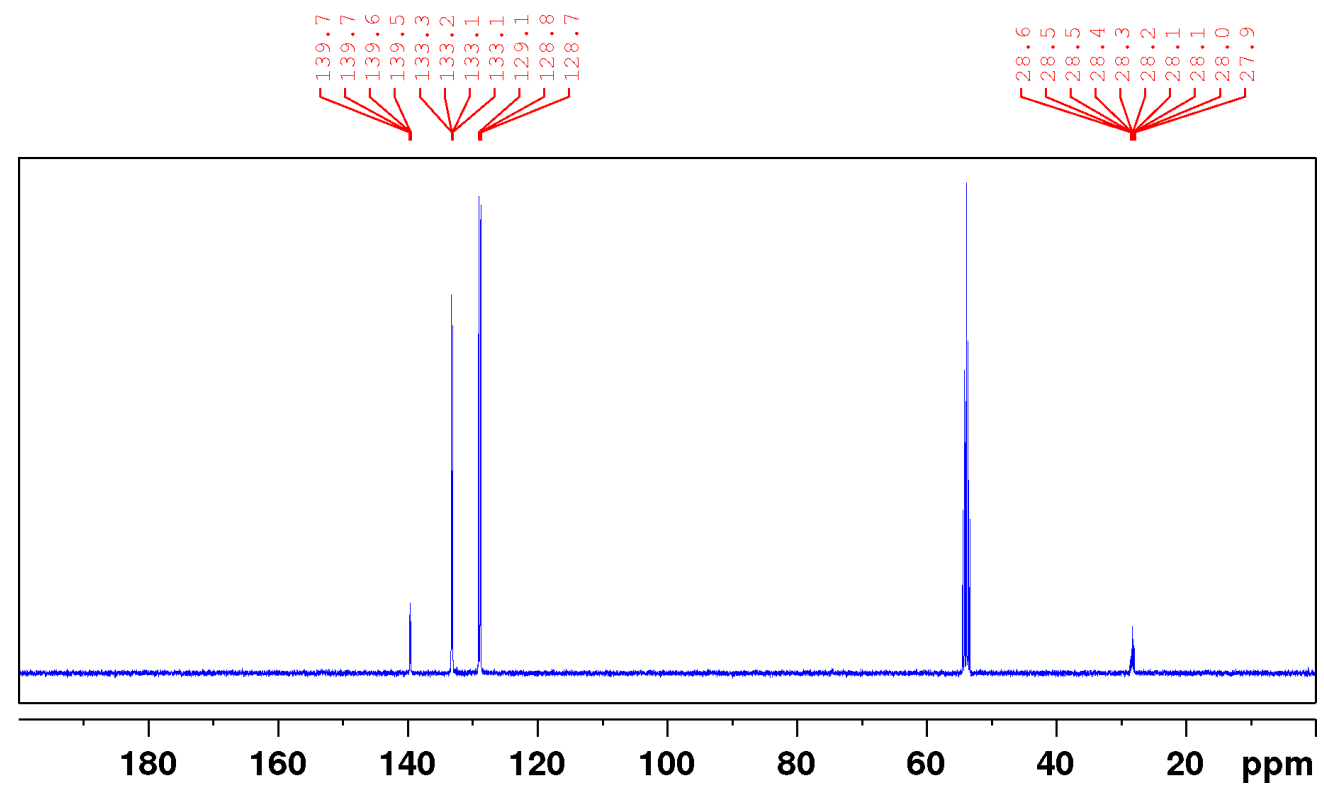

Figure S122: ${ }^{13} \mathrm{C}\left\{{ }^{1} \mathrm{H}\right\} \mathrm{NMR}\left(\mathrm{CD}_{2} \mathrm{Cl}_{2}, 101 \mathrm{MHz}, 298 \mathrm{~K}\right)$ spectrum of compound 1c. 


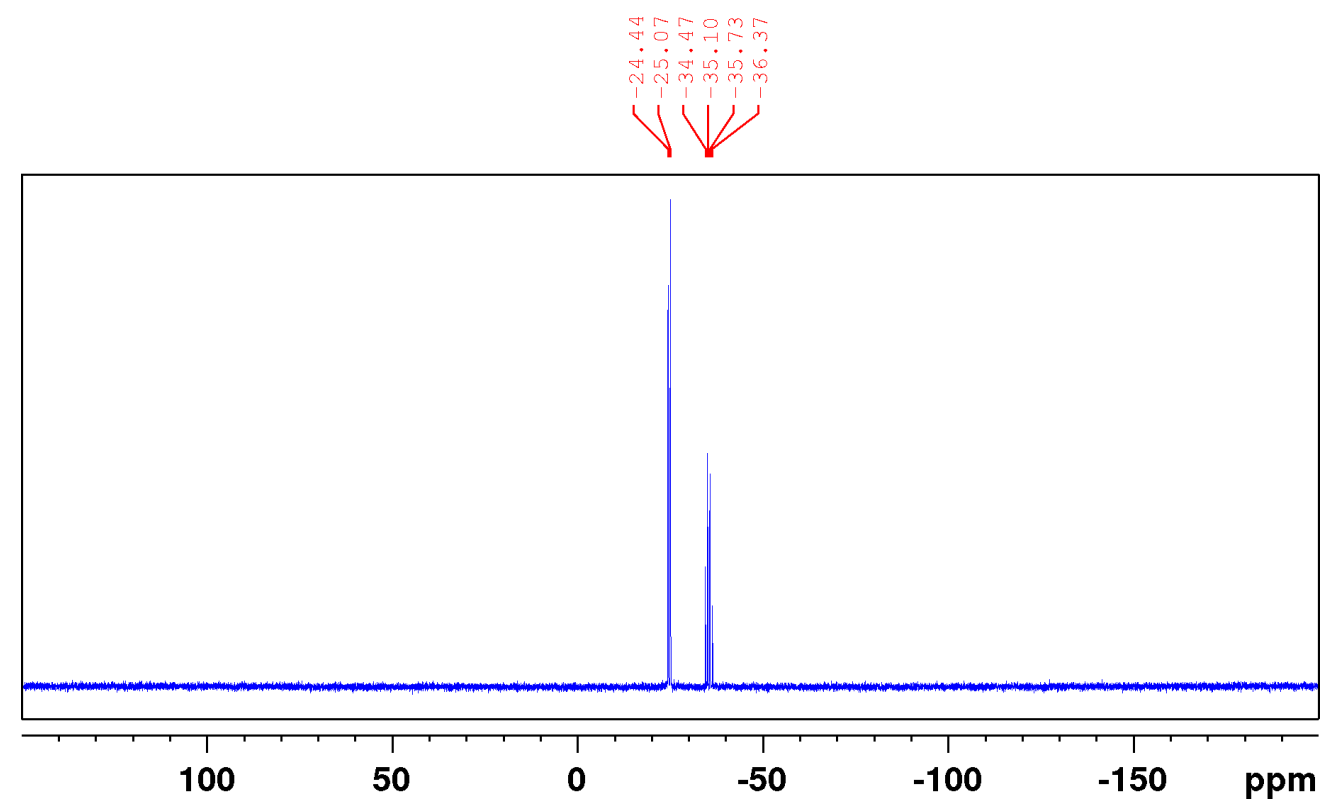

Figure S123: ${ }^{31} \mathrm{P}\left\{{ }^{1} \mathrm{H}\right\} \mathrm{NMR}\left(\mathrm{CD}_{2} \mathrm{Cl}_{2}, 162 \mathrm{MHz}, 298 \mathrm{~K}\right)$ spectrum of compound 1c. 


\subsection{NMR Spectra of the Complexes}

\subsection{1 $\left[R u\left({ }^{\mathrm{Ph}}\right.\right.$ Si-triphos $\left.\left.{ }^{\mathrm{Ph}}\right)(\mathrm{tmm})\right] 2 \mathrm{a}$}

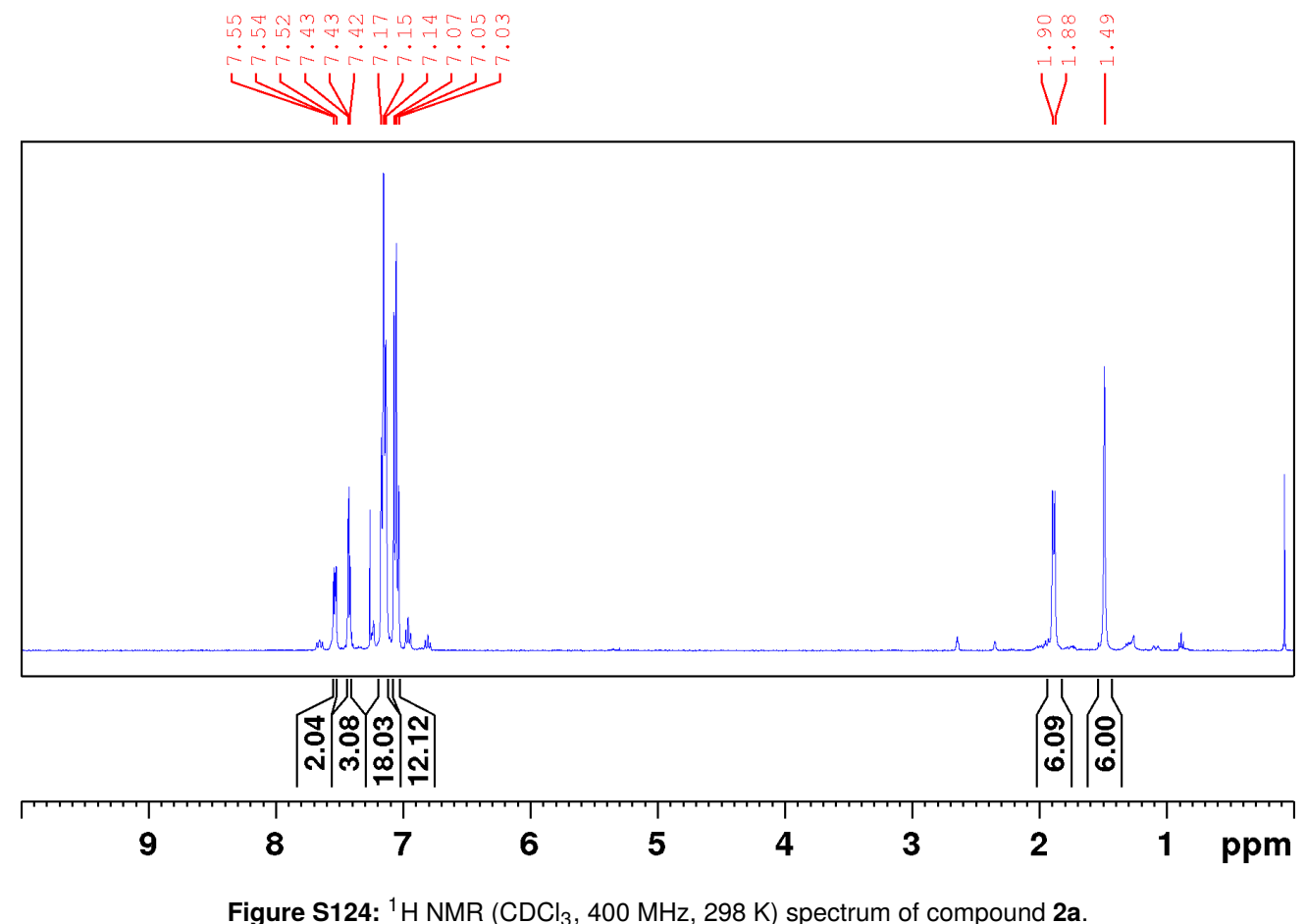

Figure S124: ${ }^{1} \mathrm{H}$ NMR $\left(\mathrm{CDCl}_{3}, 400 \mathrm{MHz}, 298 \mathrm{~K}\right)$ spectrum of compound $2 \mathrm{a}$. 


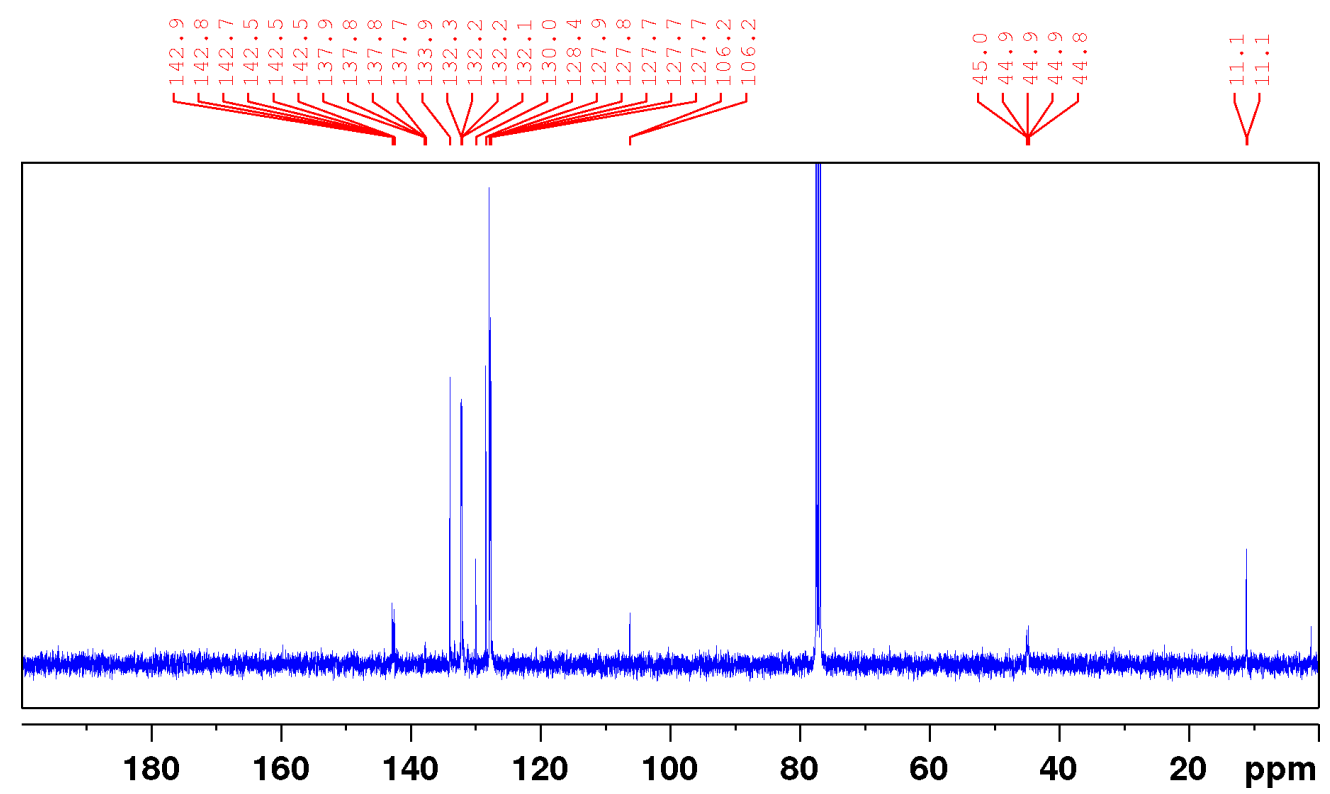

Figure S125: ${ }^{13} \mathrm{C}\left\{{ }^{1} \mathrm{H}\right\} \mathrm{NMR}\left(\mathrm{CDCl}_{3}, 101 \mathrm{MHz}, 298 \mathrm{~K}\right)$ spectrum of compound $2 \mathbf{a}$.

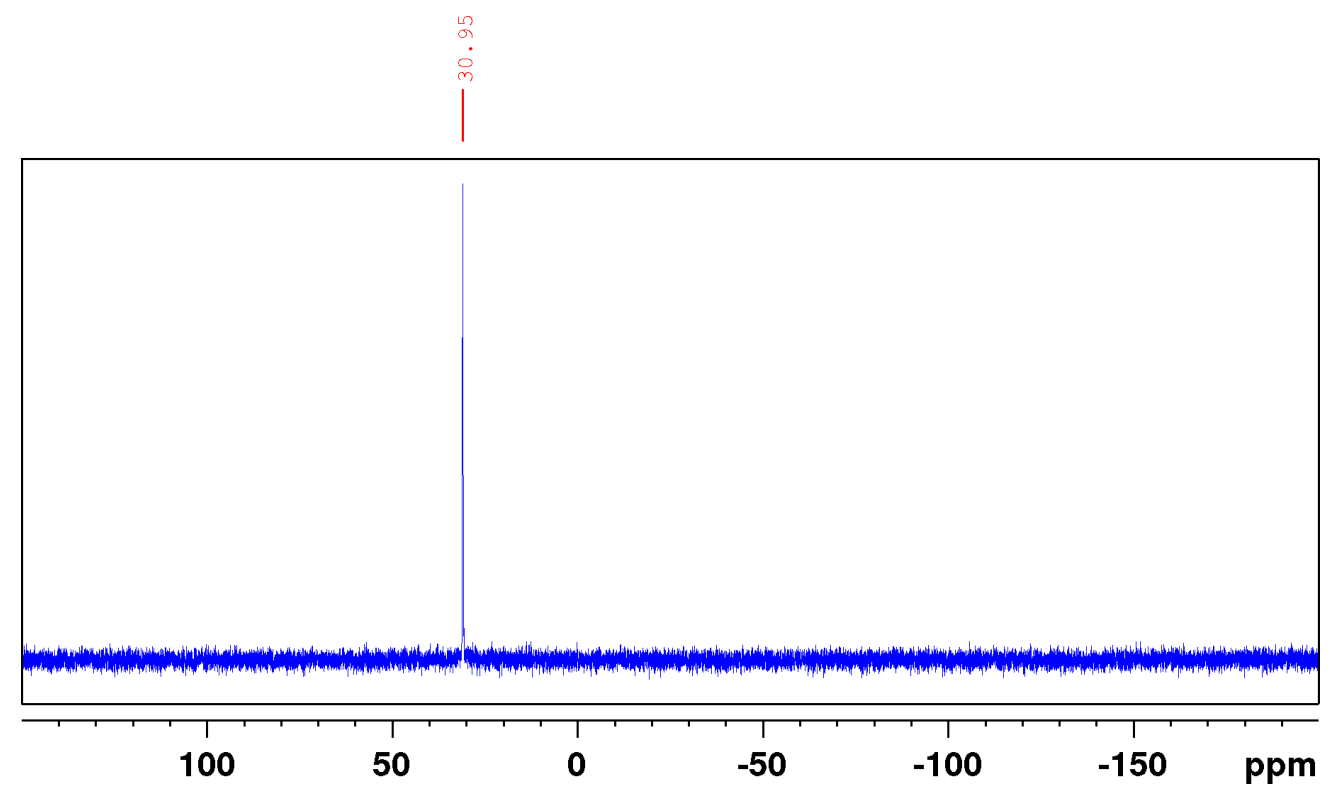

Figure S126: ${ }^{31} \mathrm{P}\left\{{ }^{1} \mathrm{H}\right\} \mathrm{NMR}\left(\mathrm{CDCl}_{3}, 162 \mathrm{MHz}, 298 \mathrm{~K}\right)$ spectrum of compound $2 \mathrm{a}$. 


\subsection{2 $\left[\mathrm{Ru}\left({ }^{\mathrm{Me}}\right.\right.$ Si-triphos $\left.\left.{ }^{\mathrm{Ph}}\right)(\mathrm{tmm})\right] 2 \mathrm{~b}$}

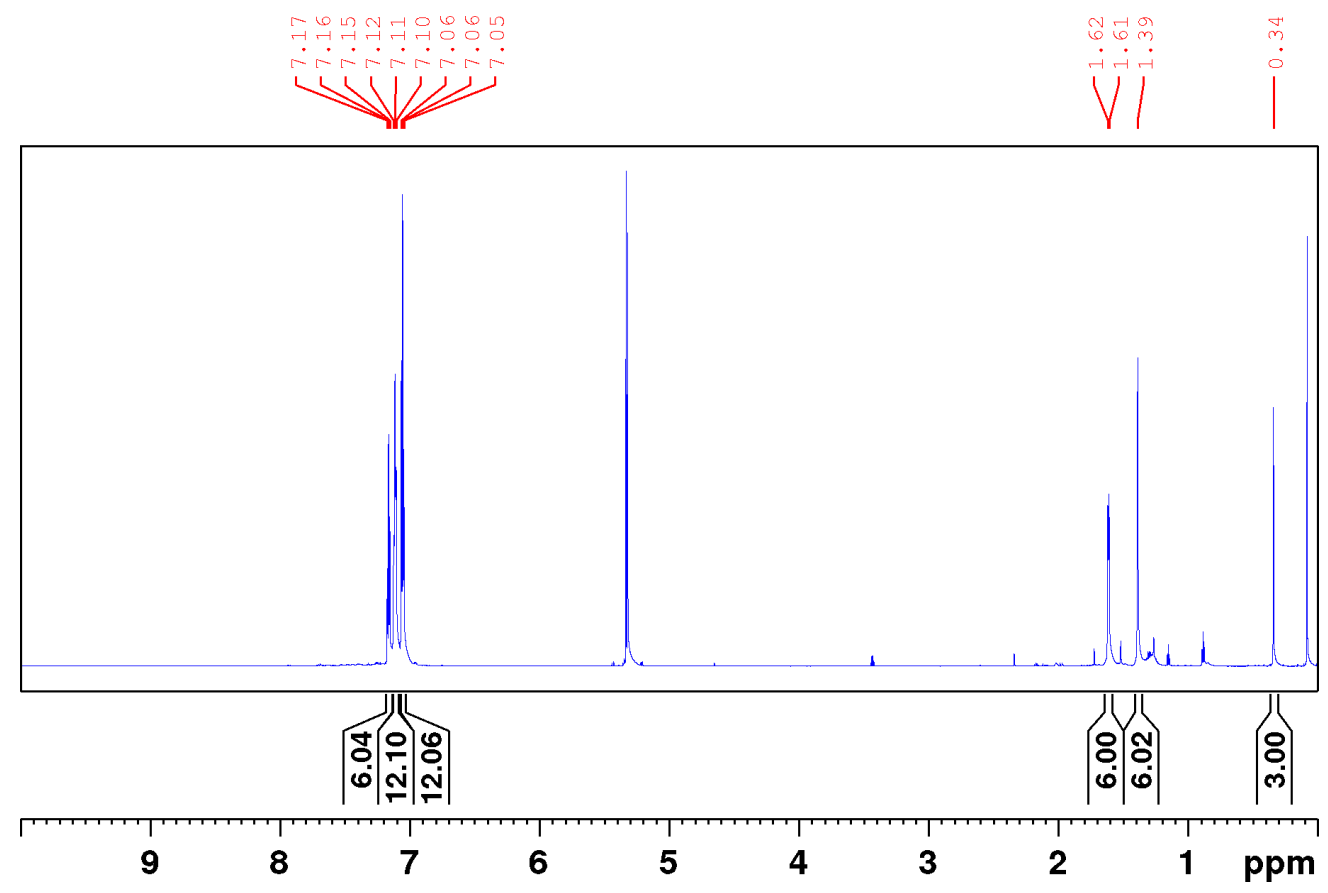

Figure S127: ${ }^{1} \mathrm{H}$ NMR $\left(\mathrm{CD}_{2} \mathrm{Cl}_{2}, 800 \mathrm{MHz}, 298 \mathrm{~K}\right)$ spectrum of compound $\mathbf{2 b}$.

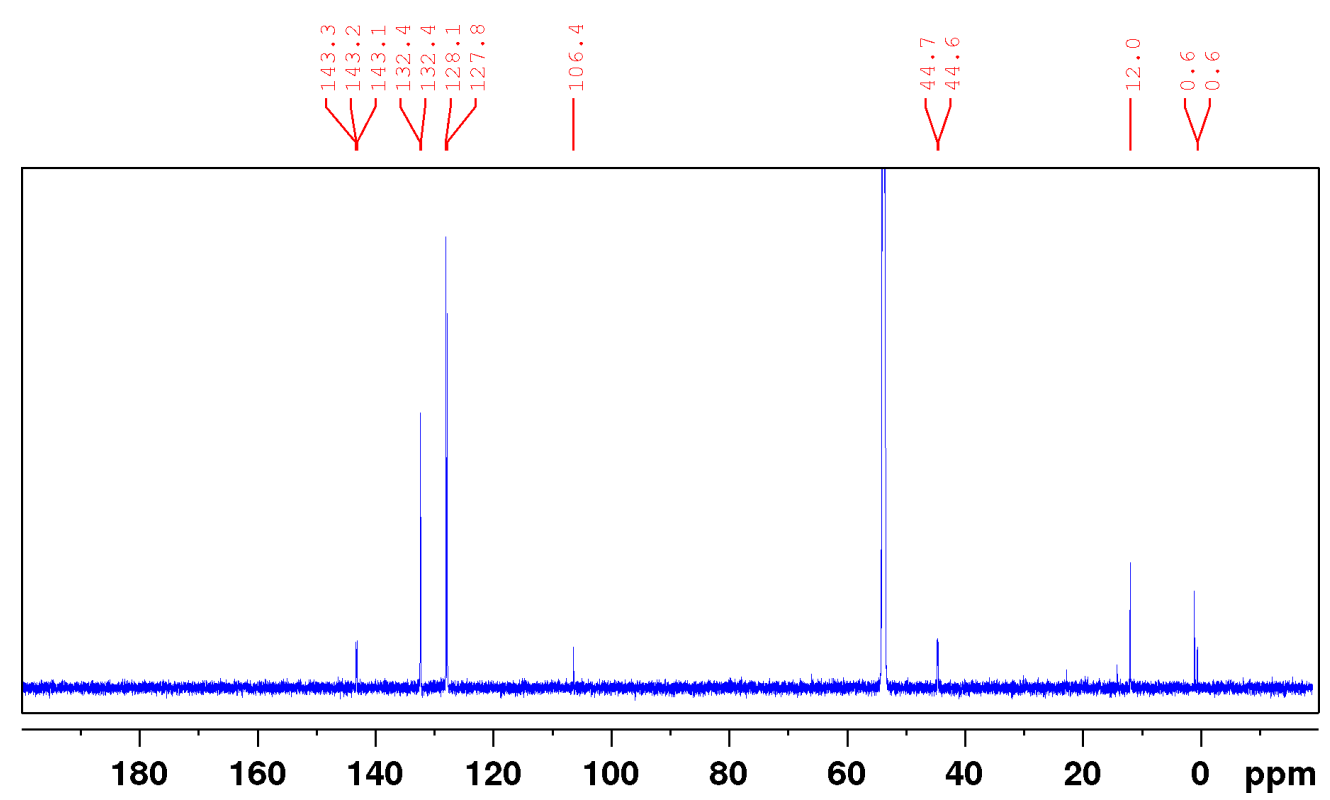

Figure S128: ${ }^{13} \mathrm{C}\left\{{ }^{1} \mathrm{H}\right\} \mathrm{NMR}\left(\mathrm{CD}_{2} \mathrm{Cl}_{2}, 201 \mathrm{MHz}, 298 \mathrm{~K}\right)$ spectrum of compound $\mathbf{2 b}$ 


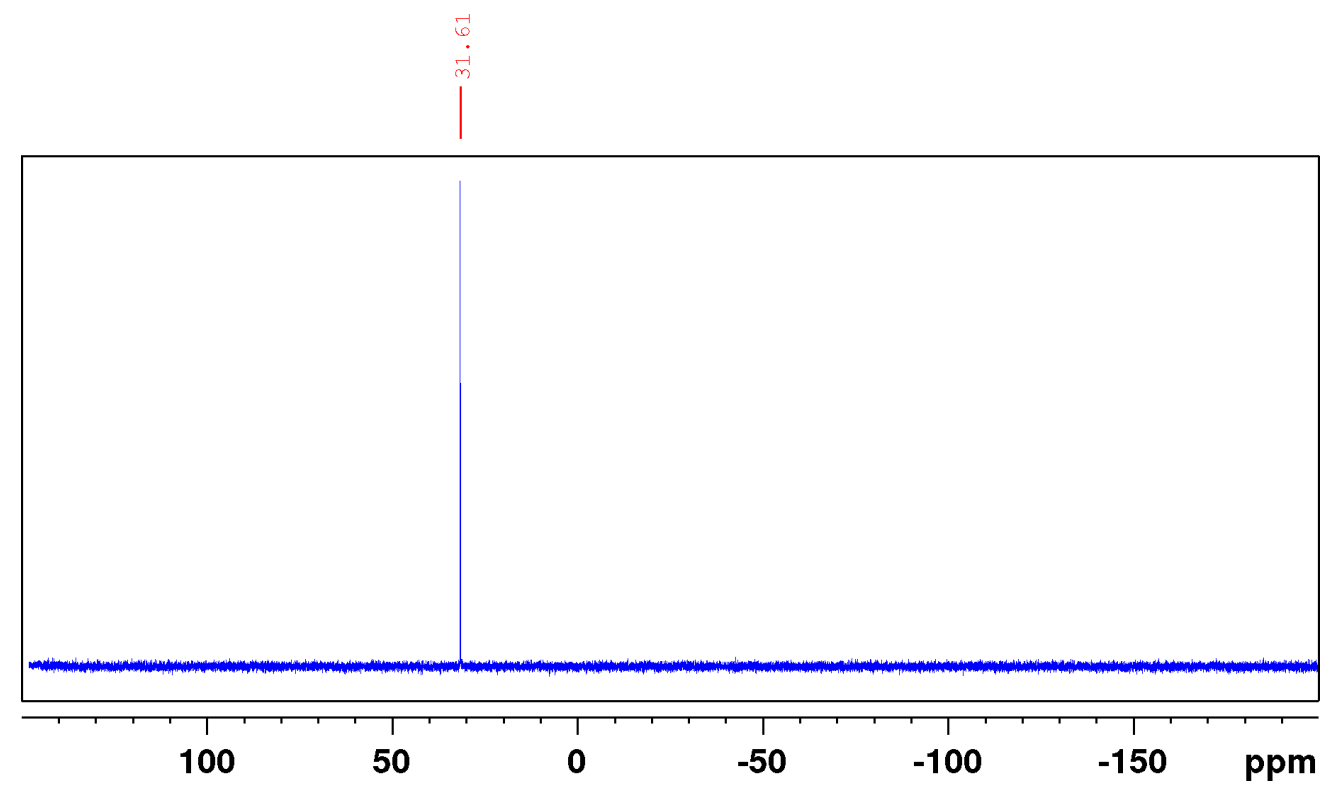

Figure S129: ${ }^{31} \mathrm{P}\left\{{ }^{1} \mathrm{H}\right\} \mathrm{NMR}\left(\mathrm{CD}_{2} \mathrm{Cl}_{2}, 162 \mathrm{MHz}, 298 \mathrm{~K}\right)$ spectrum of compound $\mathbf{2 b}$ 


\subsection{3 $\left[\mathrm{Ru}\left(\boldsymbol{P}\right.\right.$-triphos $\left.\left.{ }^{\mathrm{Ph}}\right)(\mathrm{tmm})\right] 2 \mathrm{C}$}

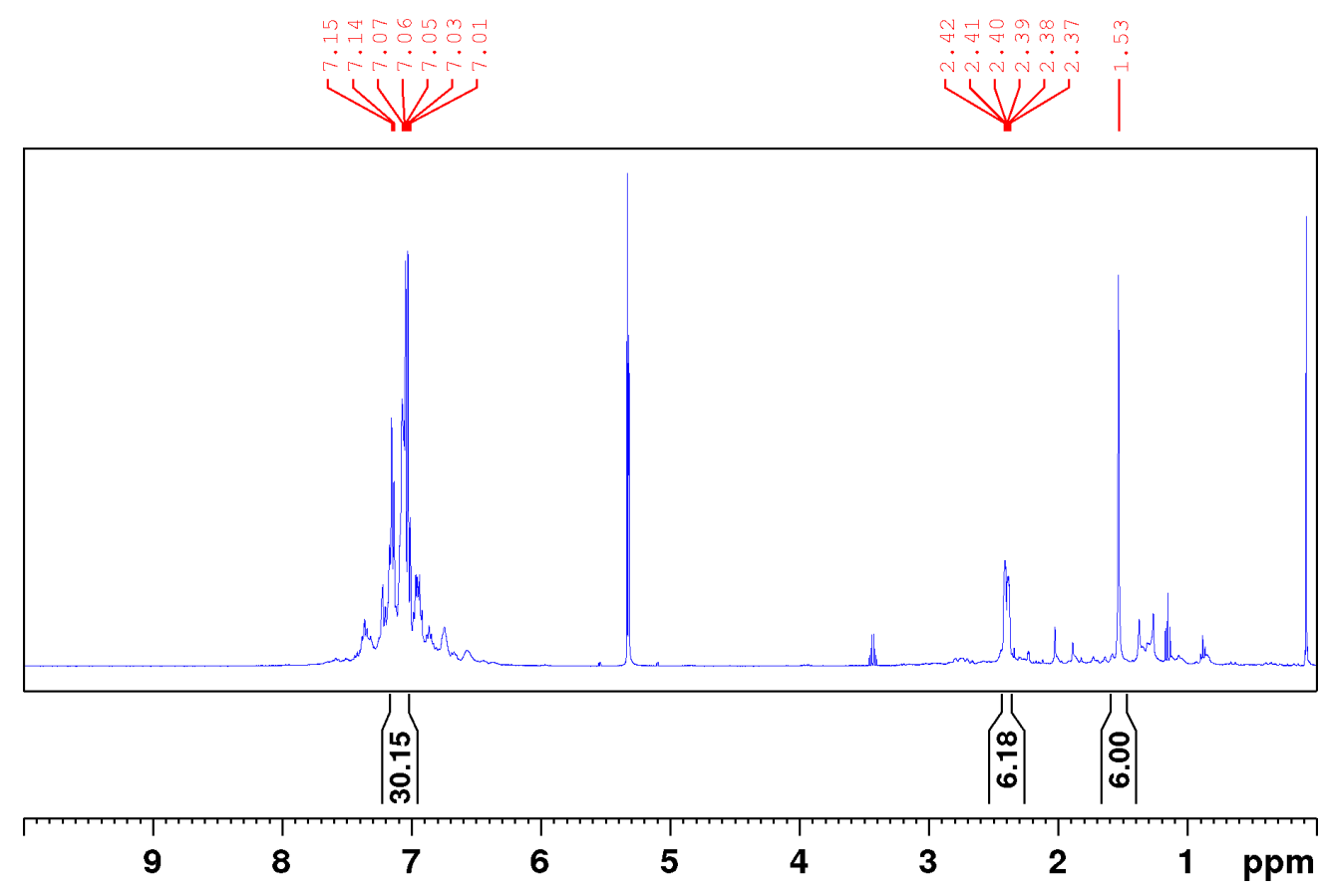

Figure S130: ${ }^{1} \mathrm{H}$ NMR $\left(\mathrm{CD}_{2} \mathrm{Cl}_{2}, 400 \mathrm{MHz}, 298 \mathrm{~K}\right)$ spectrum of compound $2 \mathrm{c}$.

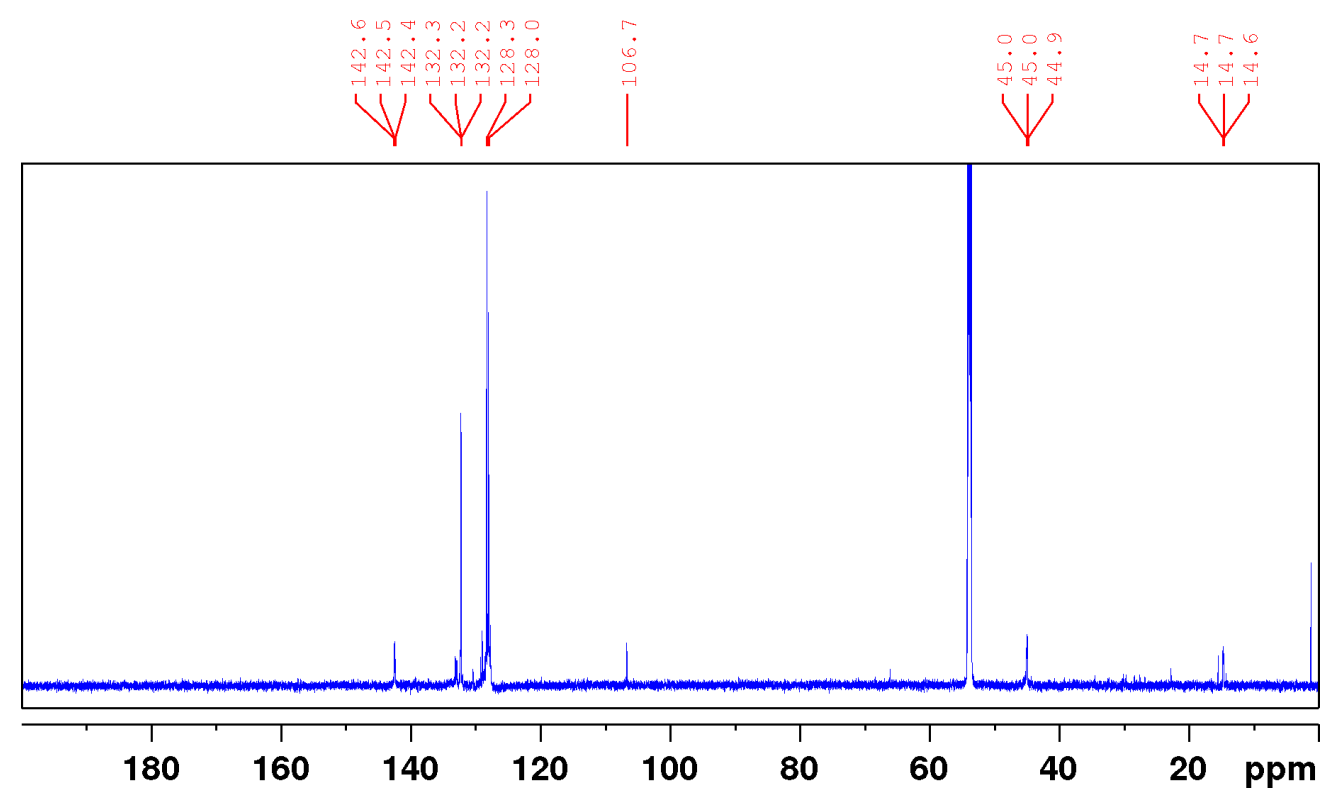

Figure S131: ${ }^{13} \mathrm{C}\left\{{ }^{1} \mathrm{H}\right\} \mathrm{NMR}\left(\mathrm{CD}_{2} \mathrm{Cl}_{2}, 201 \mathrm{MHz}, 298 \mathrm{~K}\right)$ spectrum of compound $2 \mathrm{c}$. 




Figure S132: ${ }^{31} \mathrm{P}\left\{{ }^{1} \mathrm{H}\right\} \mathrm{NMR}\left(\mathrm{CD}_{2} \mathrm{Cl}_{2}, 162 \mathrm{MHz}, 298 \mathrm{~K}\right)$ spectrum of compound $2 \mathrm{c}$. 


\subsection{4 [Ru(triphos $\left.\left.{ }^{\mathrm{Ph}}\right)(\mathrm{tmm})\right] \mathrm{SI}-4$}

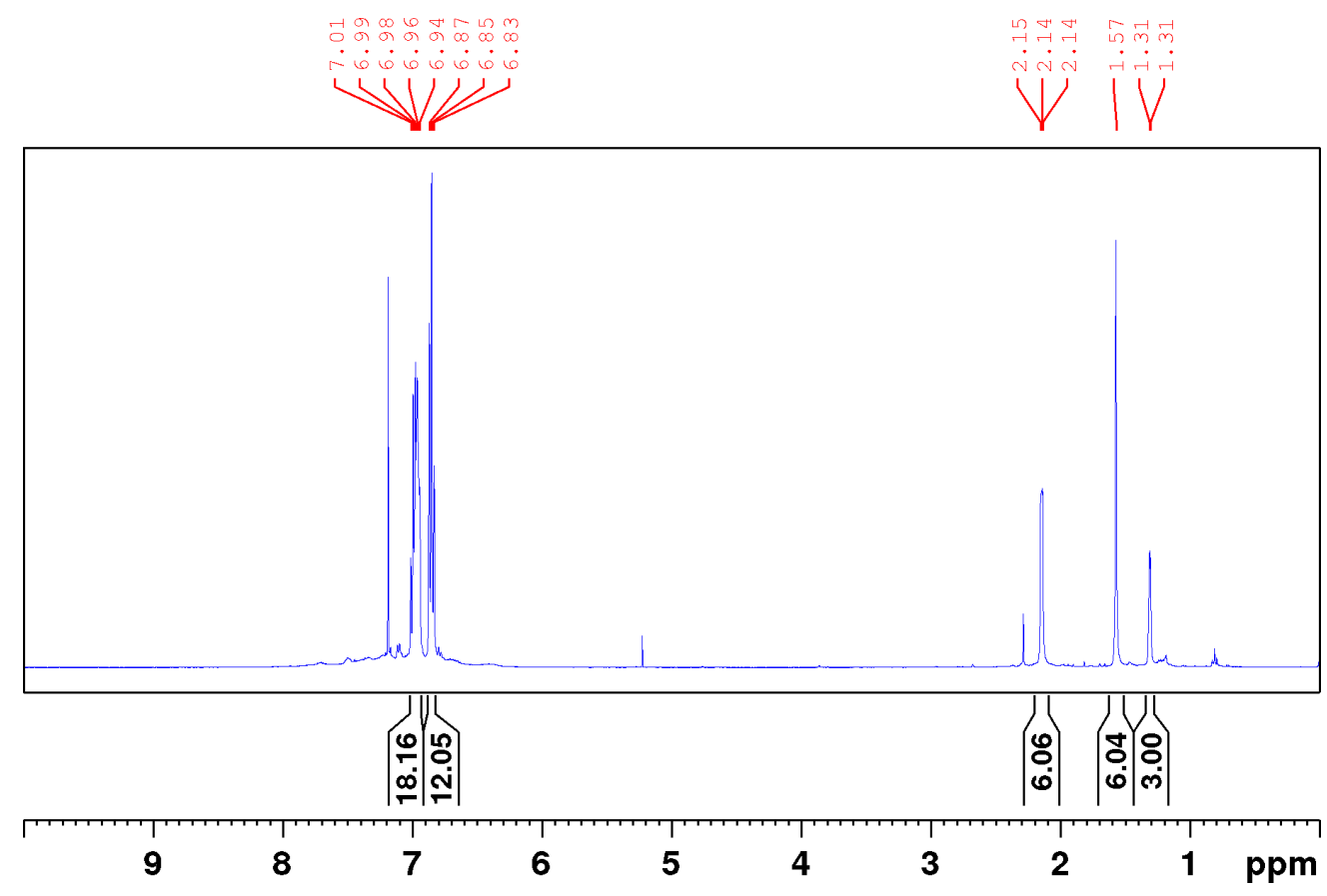

Figure S133: ${ }^{1} \mathrm{H} \mathrm{NMR}\left(\mathrm{CDCl}_{3}, 400 \mathrm{MHz}, 298 \mathrm{~K}\right)$ spectrum of compound SI-4.

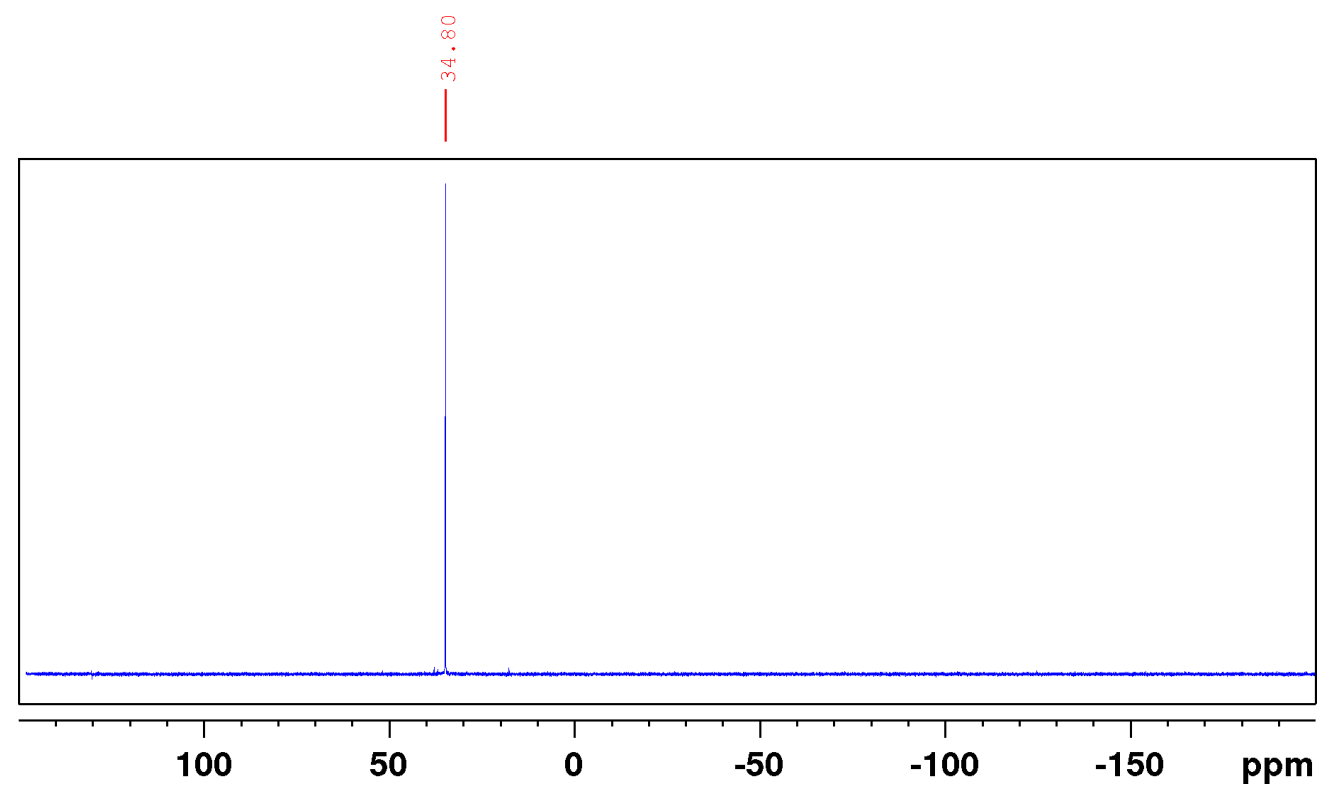

Figure S134: ${ }^{31} \mathrm{P}\left\{{ }^{1} \mathrm{H}\right\} \mathrm{NMR}\left(\mathrm{CDCl}_{3}, 162 \mathrm{MHz}, 298 \mathrm{~K}\right)$ spectrum of compound SI-4. 


\section{List of Abbreviations}

\begin{tabular}{cl}
\hline Abbreviation & Full Name \\
\hline add & Additive \\
ACN & Acetonitrile \\
ATR & Attenuated Total Reflection \\
Bu & Butyl \\
cat & Catalyst \\
CCDC & Cambridge Crystallographic Data Centre \\
COD & Cycloocta-1,5-diene \\
COSY & Correlation Spectroscopy \\
d & Doublet \\
DCM & Dichloromethane \\
DMM & Dimethoxymethane \\
EA & Elemental Analysis \\
ESI & Electrospray Ionization \\
Et & Ethyl \\
eq. & Equivalents \\
FIA & Flow Injection Analysis \\
FT & Fourier Transformation \\
FT-ICR & Fourier Transform Ion Cyclotron Resonance \\
HMBC & Heteronuclear Multiple-Bond Correlation \\
HR & High Resolution \\
HSQC-ME & Heteronuclear Single-Quantum Correlation Multiplicity-edited \\
IR & Infrared \\
IUPAC & International Union of Pure and Applied Chemistry \\
LTQ & Linear Ion Trap Quadrupole \\
& \\
\hline IS & \\
\hline
\end{tabular}




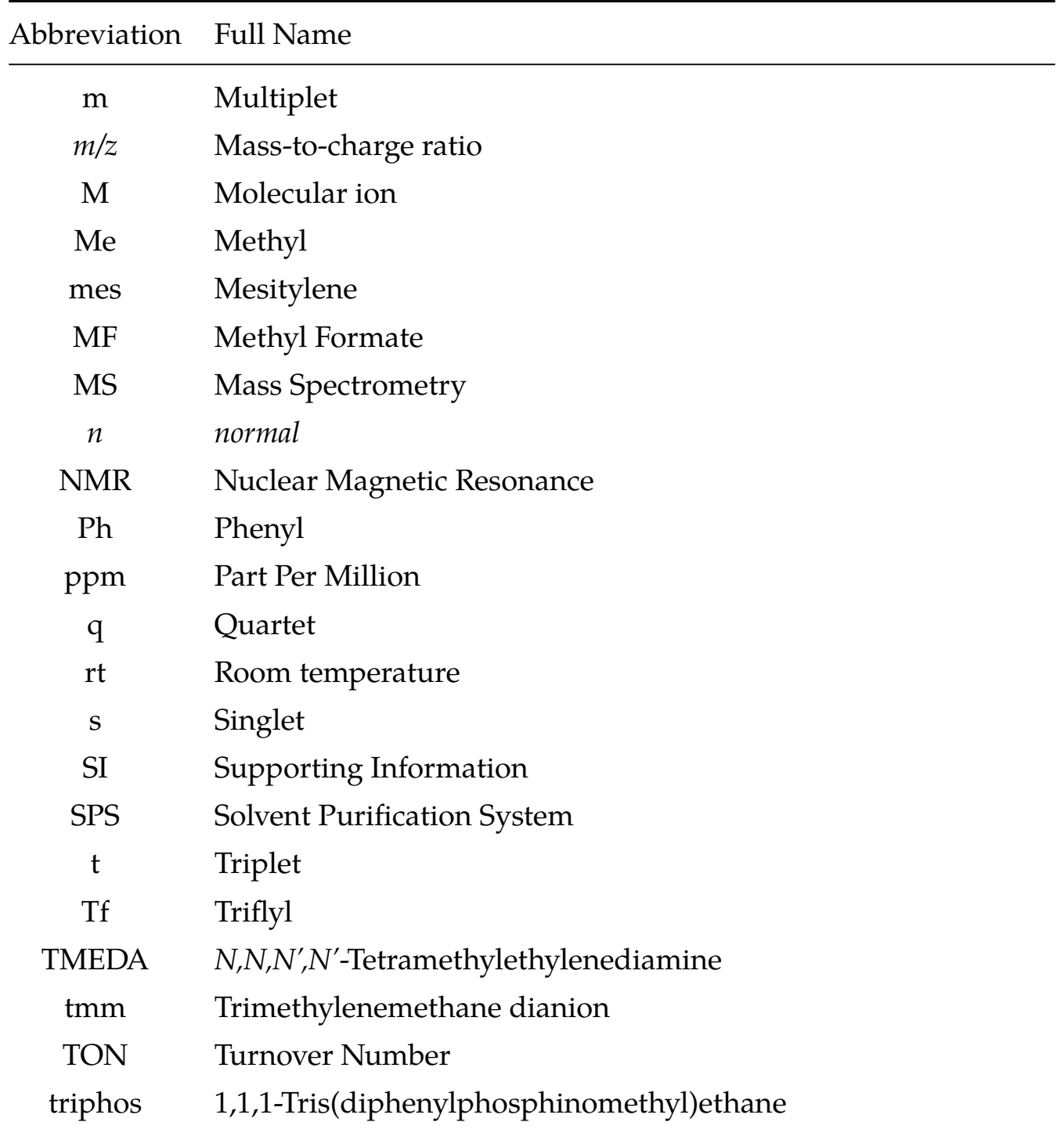




\section{Bibliography}

[1] Fulmer, G. R.; Miller, A. J. M.; Sherden, N. H.; Gottlieb, H. E.; Nudelman, A.; Stoltz, B. M.; Bercaw, J. E.; Goldberg, K. I. Organometallics 2010, 29, 2176-2179.

[2] Fildes, J. E. Microchim. Acta 1970, 58, 978-982.

[3] Schore, N. E.; Benner, L. S.; LaBelle, B. E. Inorg. Chem. 1981, 20, 3200-3208.

[4] Neumeyer, F.; Lipschutz, M. I.; Tilley, T. D. Eur. J. Inorg. Chem. 2013, 2013, 6075-6078.

[5] Herold, S.; Mezzetti, A.; Venanzi, L. M.; Albinati, A.; Lianza, F.; Gerfin, T.; Gramlich, V. Inorg. Chim. Acta 1995, 235, 215-231.

[6] Cámpora, J.; Maya, C. M.; Matas, I.; Claasen, B.; Palma, P.; Álvarez, E. Inorg. Chim. Acta 2006, 359, 3191-3196.

[7] Wesselbaum, S.; vom Stein, T.; Klankermayer, J.; Leitner, W. Angew. Chem. Int. Ed. 2012, 51, 7499-7502.

[8] Vom Stein, T.; Weigand, T.; Merkens, C.; Klankermayer, J.; Leitner, W. ChemCatChem 2013, 5, 439-441.

[9] Siebert, M.; Seibicke, M.; Siegle, A. F.; Kräh, S.; Trapp, O. J. Am. Chem. Soc. 2019, 141, 334-341. 